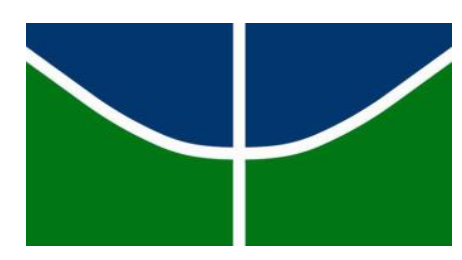

UNIVERSIDADE DE BRASÍLIA

INSTITUTO DE LETRAS

DEPARTAMENTO DE LINGUÍSTICA, PORTUGUÊS E LÍNGUAS CLÁSSICAS PROGRAMA DE PÓS-GRADUAÇÃO EM LINGUÍSTICA

\title{
ASPECTOS SINTÁTICOS E SEMÂNTICOS DE SENTENÇAS IMPERATIVAS NO PORTUGUÊS BRASILEIRO
}

BRASÍLIA

2016 
MOACIR NATERCIO FERREIRA JUNIOR

\section{ASPECTOS SINTÁTICOS E SEMÂNTICOS DE SENTENÇAS IMPERATIVAS NO PORTUGUÊS BRASILEIRO}

Tese apresentada ao Programa de PósGraduação em Linguística da Universidade de Brasília como requisito parcial para a obtenção do título de Doutor em Linguística.

Área de concentração: Teoria e Análise Linguística, sob orientação da Profa. Dra. Heloísa Maria Moreira Lima Salles 


\section{ASPECTOS SINTÁTICOS E SEMÂNTICOS DE SENTENÇAS IMPERATIVAS NO PORTUGUÊS BRASILEIRO}

Tese apresentada ao Programa de Pós-Graduação em Linguística da Universidade de Brasília como requisito parcial para a obtenção do título de Doutor em Linguística.

Área de concentração: Teoria e Análise Linguística, sob orientação da Profa. Dra. Heloísa Maria Moreira Lima Salles.

\section{Banca examinadora}

Dra. Heloisa Maria Moreira Lima Salles (Presidente) - Universidade de Brasília

Dra. Maria Marta Pereira Scherre (Membro externo) - PPGL/UFES

Dra. Jânia Martins Ramos (Membro externo) - PPGL/UFMG

Dr. Marcus Vinicius da Silva Lunguinho (Membro interno) - LIP/UnB

Dr. Paulo Medeiros Junior (Membro interno) - LIP/UnB

Dra. Rozana Reigota Naves (Suplente) - PPGL/UnB 
Ao maior vascaíno de todos os tempos. 


\section{AGRADECIMENTOS}

Primeiramente a Deus, que me permitiu realizar esse projeto.

Ao meu querido pai, Moacir Natercio Ferreira (in memorian). Seus exemplos de honra, honestidade, humildade e respeito me guiam todos os dias na busca de ser uma pessoa melhor.

À minha mãe, Ilca Guimarães da Silva Ferreira que, em seu notável exemplo de mulher virtuosa, nunca me deixou sucumbir ao desânimo. Antes me lembrava sempre que um dia todo o esforço seria recompensado. Nesses últimos anos, nós temos enfrentado juntos situações muito difíceis, mas sempre me senti apoiado por seu ânimo, paciência e sabedoria.

À minha esposa, Mircéa Cândida Ferreira, por ser tão disposta a fazer tudo o que for preciso para me ver feliz. Por ser tão compreensiva e paciente em meus momentos de cansaço. Obrigado por sua fofura traduzida em seus muitos sorrisos!

À minha orientadora, Dra. Heloísa Maria Moreira Lima Salles, pela paciência e dedicação, mesmo diante de tantos compromissos. Obrigado por compartilhar por tantos anos suas ideias comigo. Sua dedicação, seu compromisso e sua boa vontade me inspiram a ser um profissional melhor. Agradeço por esse projeto, pelas noites de estudo, pelos quebra-cabeças que enfrentei, pelas soluções que alcançamos, enfim, por toda a trajetória.

Ao professor Dr. Marcus Lunguinho, por sua disposição ao me ajudar em diversos momentos dessa pesquisa. Obrigado por ser um referencial de competência na nossa área e sempre demonstrar muita humildade e paciência para ensinar.

Aos professores convidados a compor a banca, Dra. Maria Marta Pereira Scherre, Dra. Jânia Martins Ramos, Dr. Paulo Medeiros Junior, Dr. Marcus Vinícius da Silva Lunguinho e Dra. Rozana Reigota Naves. Tenho muito orgulho de ter em minha banca professores que aprendi a admirar durante o desenvolvimento dessa pesquisa. Suas contribuições e seus trabalhos me inspiraram durante a investigação dos problemas e no desenvolvimento dessa pesquisa.

Aos professores do Programa de Pós-Graduação em Linguística da Universidade de Brasília. Sou muito grato a todos vocês por cada contribuição em minha formação.

Por fim, aos meus alunos, que são o maior motivo de dedicação de todos os meus trabalhos. 
"O mais importante e bonito, do mundo, é isto: que as pessoas não estão sempre iguais, ainda não foram terminadas - mas que elas vão sempre mudando."

Grande Sertão Veredas 


\section{ASPECTOS SINTÁTICOS E SEMÂNTICOS DE SENTENÇAS IMPERATIVAS NO PORTUGUÊS BRASILEIRO \\ RESUMO}

Este trabalho investiga aspectos da estrutura sintática das sentenças imperativas no português brasileiro (PB), na comparação com o português europeu (PE). A tradição gramatical classifica o PE como língua de imperativo verdadeiro, por possuir morfologia verbal específica ao modo imperativo. Além da morfologia própria (1), entre as particularidades das formas verbais do imperativo verdadeiro, constam (i) a impossibilidade de realização de sujeito pré-verbal (2), (ii) a impossibilidade de negar a formas do imperativo verdadeiro, sendo utilizada, nesse caso, a forma 'supletiva', advinda do subjuntivo ((1) Entra! (2p)/ Entre! (3p.gramatical); (2) *Tu entra/ *Você entra!/ (3) *Não entra!/ Não entres (2p)/ Não entre! (3p.gramatical)) - características também encontradas em línguas próximas, como o espanhol (MATEUS et alii. 2003; RIVERO, 1994). Já o PB apresenta duas formas verbais em variação (associadas, por hipótese, ao indicativo e ao subjuntivo), cuja distribuição não apresenta restrições ao uso da negação, a qual pode ocorrer em três configurações - em posição pré-verbal, em posição pré- e pós-verbal, em posição pós-verbal -, além de manifestar uma forma reduzida na posição pré-verbal (Não/Num faz/faça isso; Não/Num faz/faça isso não; Faz/Faça isso não). Outra característica do imperativo no PB é a possibilidade de realização do sujeito em posição pré-verbal e pós-verbal ((4) Você entra/entre aqui!; Entra/Entre você aqui!). Seguindo primordialmente Cardoso (2004; 2009); Scherre (2007) e Scherre et al. (2007), assumimos que o modo imperativo no PB, sendo realizado por formas variantes sem restrição de distribuição no que se refere à presença da negação, não manifesta o chamado imperativo verdadeiro, fazendo uso de um paradigma supletivo para expressar o modo imperativo - tanto em relação às formas do indicativo, quanto em relação às formas do subjuntivo. Assumindo-se que o desenvolvimento do paradigma supletivo associado ao indicativo (em variação com as formas associadas ao subjuntivo) relaciona-se à reanálise do sistema pronominal e ao sincretismo morfológico decorrente dessa reanálise, propomos que as sentenças imperativas no PB são enunciados optativos, que ocorrem em uma configuração em que o traço optativo, licenciado por um operador expressivo (EX), é realizado no domínio de CP (nos termos de Grosz 2011). Esse operador é responsável por avaliar o conteúdo da elocução imperativa denotada na na estrutura de CP, em relação ao desejo do emissor ( $1^{a}$ pessoa do discurso). A expectativa do emissor é matizada por efeitos de polidez, que se manifestam na relação com o sistema pronominal e com a sintaxe do sujeito - em que a realização nula alterna com a realização lexical, em posição pré-verbal (não marcada), em contraste com a posição pós-verbal (marcada). Enquanto o operador optativo representa em $\mathrm{C}$ a expressão do emissor, o traço de segunda pessoa, referente ao destinatário da elocução imperativa, é representado no núcleo da categoria ModP (ModalityPhrase) por meio do traço de segunda pessoa (nos termos da proposta original de ZANUTTINI 2008, reformulada em ISAC 2015). Seguindo o pressuposto de que o ato de elocução é realizado em duas instâncias (ISAC 2015), propomos que, nas sentenças imperativas no $\mathrm{PB}$, o primeiro evento de causa está diretamente associado à presença do operador optativo em $\mathrm{C}$, e representa a expectativa que o emissor tem ao realizar a proposição inicial do ato de elocução e o segundo evento de causa está associado ao traço de segunda pessoa hospedado na categoria Mod.

PALAVRAS-CHAVE: imperativo; forma supletiva; traço optativo; ordem SV/VS. 


\title{
SYNTACTICAL AND SEMANTIC ASPECTS OF IMPERATIVE CLAUSES IN BRAZILIAN PORTUGUESE
}

\begin{abstract}
This work investigates aspects related to the syntactic structure of the imperative clauses in Brazilian Portuguese (BP), compared to European Portuguese (EP). The grammatical tradition classifies EP as a language of the true imperative type, because it employs a specific morphology for the expression of the imperative mood, showing syntactic particularities in the presence of this verbal form. Besides presenting specific morphology (1), the true imperative verbal form (i) does not allow perform pre-verbal subject (2), (ii) neither deny imperative true forms, being used, in this case, a suppletive form, which arises from subjunctive paradigm ((1) Entre! (2P) / Entra! (3P.gramatical) (2) * Você entre! / * Você entra! / (3) * Não entre! / Não entres! (2P) / Não entra! (3P.gramatical)) - characteristics also found in similar languages, such as Spanish (MATEUS et al. 2003; RIVERO, 1994). On the other hand, imperative clauses in BP has two verbal forms in variation, whose distribution has no restrictions on the presence of negative markers, which can occur in three configurations - pre-verbal position, in pre and post-verbal position in postverbal position - besides presenting a reduced form in pre-verbal position (Não/Num faz/faça isso; Não/Num faz/faça isso não; Faz/Faça isso não). Another essential characteristic of BP imperative clauses is the possibility of hosting the subject in a pre-verbal and postverbal positions. According to Scherre (2007) and Scherre et al. (2007), we assume that imperative paradigm in BP do not manifest the true imperative form, but only suppletive forms by the use of indicative and subjunctive morphology. Assuming that the BP have only a suppletive paradigm, we propose that the illocutionary force, in this sentences, occurs in a configuration where the head of CP have an optative feature, which is characteristic of subordination (cf. Rivero, 1994). This feature is represented by an operator EX (according Grosz, 2011) which denotes the first person expression in the speech act of optative utterances. This operator is responsible for evaluating the expressive content of the imperative utterance, expressed by the proposition introduced in the structure of the CP projection, marking the speaker's desire (1st person of the speech act). The speaker's expectation is nuanced by politeness effects, which are manifested in the relation with the pronominal system and with the subject imperative syntax - in which the null realization alternates with the lexical realization, in a pre-verbal (unmarked) position, in contrast with the post-verbal (marked) position. Thus, while the optative operator represents the speaker's expression in $\mathrm{C}$, the second person's feature, referring to the Addressee of the imperative utterance, is represented in the core of the ModP category (ModalityPhrase). Following Isac (2015), we propose that the imperative utterance occurs in two differents causal events. The first cause event is directly associated with the presence of the optative operator in $\mathrm{C}$ and represents the speaker's expectation of performing the initial proposition of the utterance act. The second cause event is associated with the second person feature hosted in the head of Mod category.
\end{abstract}

Keywords: true imperative, suppletive form, optative feature, VS/SV order 


\section{LISTA DE ABREVIATURAS E SÍMBOLOS}

* - Sentença agramatical $(* \mathrm{X})$

? - Dúvida sobre juízo de gramaticalidade

$\Sigma \mathrm{P}$ - Sigma Phrase

2P - Segunda Pessoa

A - Posição argumental

$\overline{\mathrm{A}}$ - Posição não-argumental

AgrP - Agreement Phrase

AP - Adjetive Phrase

AspP - Aspect Phrase

AUX - Auxiliar

CP - Complementizer Phrase

DP - Determiner Phrase

EPP - Extended Projection Principle

EX - Operador expressivo optativo

$\mathrm{f}(\mathrm{x})$ - Domínio da função sobre $\mathrm{x}$

FinP - Finiteness Phrase

FocP - Focus Phrase

FP - Functional Phrase

HMC - Head Moviment Constraint

I - Inflection

IND - Indicative

INF - Infinitive

IMP - Imperative

IP - Inflectional Phrase

JP - Jussive Phrase

LF - Logical Form

ModP Modality Phrase

NegP - Negation Phrase

NP - Noun Phrase

$\varnothing$ - Elemento nulo

$\mathrm{P} \& \mathrm{P}$ - Principles and Parameters 
MP - Minimalist Program

PB - Português brasileiro

PE - Português europeu

PolP - Polarity Phrase

PF - Phonetic Form

SeP - Speech Event Phrase

TopP - Topic Phrase

TP - Tense Phrase

U - União

VP - Verbal Phrase 


\section{LISTA DE QUADROS}

Quadro 2.1 - Tipos de modalidade na classificação de von Fintel (2006) .................................58

Quadro 2.2 - Tipos de leitura modalizada em Kratzer (1991) .................................................59

Quadro 2.3 - Conjunto de modalizações em Isac (2015) ...........................................................61

Quadro 2.4 - Tipos de elementos modais, conforme Isac (2015).............................................73

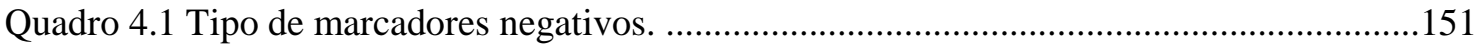

Quadro 4.2 Marcador negativo em sentenças imperativas........................................................152

Quadro 4.3 - Distribuição dos marcadores negativos no PB por tipos de sentença....................172

Quadro 4.4 - Distribuição dos marcadores negativos no PB por tipos de orações subordinadas 


\section{LISTA DE TABELAS}

Tabela 1.1 Distribuição do imperativo gramatical no eixo geográfico...............................43

Tabela 4.1 Distribuição de num de acordo com elemento na posição seguinte.............164

Tabela 4.2 Distribuição de num de acordo com grupo etário do informante......................165

Tabela 4.3 Distribuição de não e num em frases da forma [...Neg... QNeg...]...........165 


\section{CAPÍTULO 1- ESTUDOS SOBRE O IMPERATIVO GRAMATICAL NO PORTUGUÊS BRASILEIRO}

1.1 Objetivos do capítulo. .19

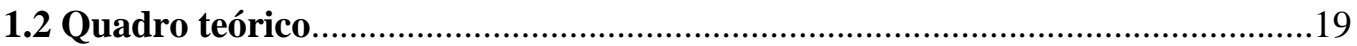

1.2.1 Pressupostos teóricos: a faculdade de linguagem..............................................19

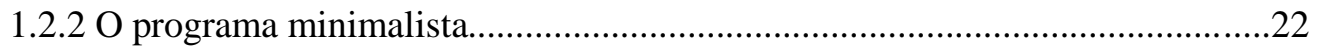

1.2.2.1 Categorias lexicais $x$ categorias funcionais: o papel do núcleo C..........24

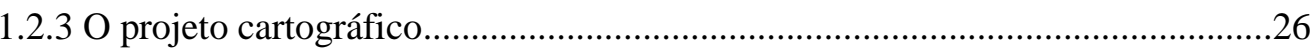

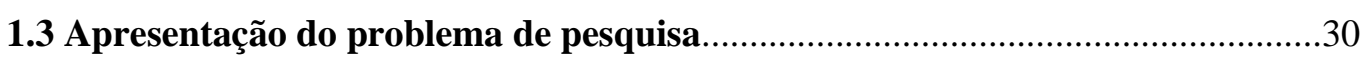

1.3.1. Caracterização translinguística do modo imperativo..........................................30

1.3.2 O modo imperativo: PE versus PB......................................................................

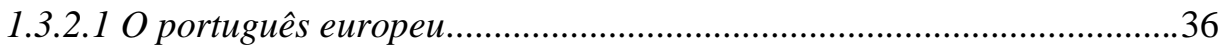

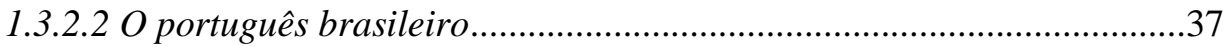

1.3.2.3 A interação discursiva e as formas do imperativo no PE e no PB .......39

1.3.3 Variação linguística e Mudança Paramétrica no imperativo no PB...................42

1.3.3.1 Fatores linguísticos associados à variação.............................................42

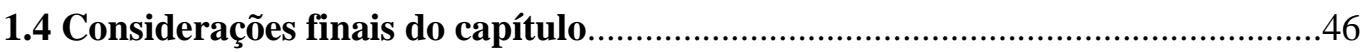

\section{CAPÍTULO 2 - MODO, MODALIDADE NA ESTRUTURA IMPERATIVA}

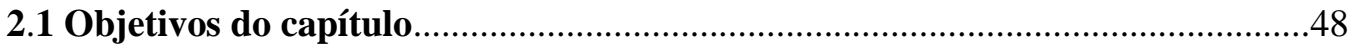

2.2 Modo, modalidade e a hipótese da projeção ModP............................................49

2.2.1 A noção de modo e modalidade: a perspectiva das gramáticas tradicionais.......41

2.2.2 A modalidade e o modo: pressupostos semânticos................................................53

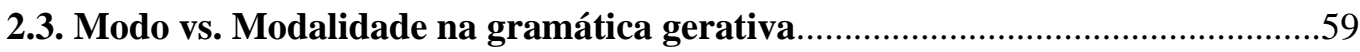

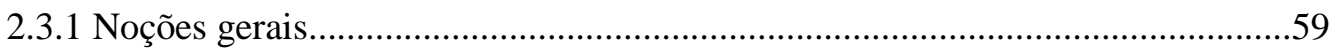

2.3.2 O imperativo não é um modal: a argumentação de Portner (2007)......................65

2.3.3Fatores relevantes para comprovação da modalidade em sentenças imperativas.66

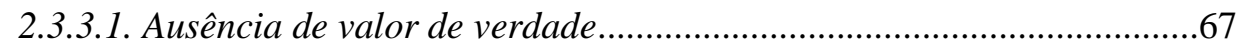

2.3.3.2 Orientação ao sujeito............................................................................68

2.3.3.3 Acarretamentos de realização no mundo real (Actuality entailments)...70 


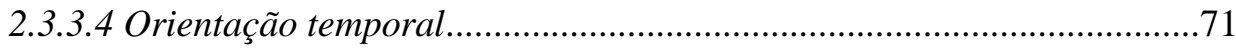

2.3.4 Posicionamento da categoria Modo na estrutura de sentenças imperativas......73

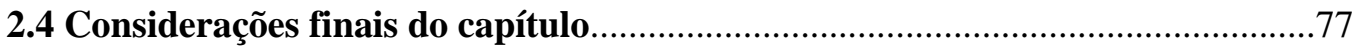

CAPÍTULO 3 - A CONFIGURAÇÃO OPTATIVA-DIRETIVA NAS SENTENÇAS IMPERATIVAS DO PB

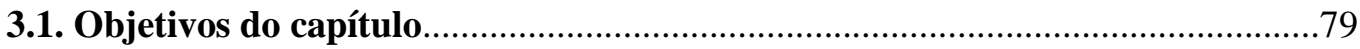

3.2 Caracterização das sentenças imperativas: aspectos gerais................................81

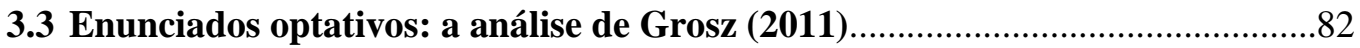

3.4 A força diretiva nas sentenças imperativas: a proposta

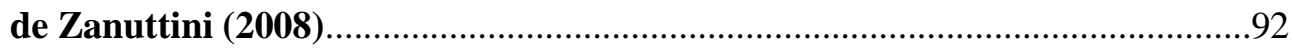

3.5 A análise sintático-semântica das sentenças imperativas: o estudo de Isac

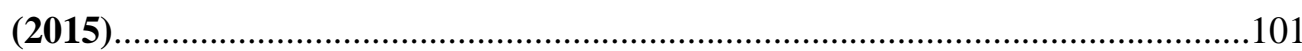

3.5.1 Uma posição na estrutura para o destinatário do ato de elocução....................101

3.5.2 A categoria $\mathrm{SeP}$ e os participantes da elocução imperativa.............................102

3.5.3 A configuração do imperativo verdadeiro.........................................................104

3.5.4 A configuração do imperativo supletivo........................................................108

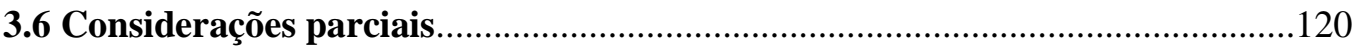

3.7 Hipótese da configuração diretivo-optativa no PB............................................123

3.7.1 As propriedades da configuração optativa em C no PB....................................123

3.7.2 O traço diretivo (de segunda pessoa) no núcleo da categoria Mod...................127

3.7.3 Posicionamento dos sujeitos nas sentenças imperativas do PB........................130

3.7.4 A derivação de sentenças imperativas no PB.....................................................139

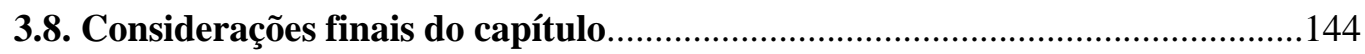

\section{CAPÍTULO 4 - A INTERAÇÃO ENTRE SENTENÇAS IMPERATIVAS E AS ESTRATÉGIAS DE NEGAÇÃO NO PB}

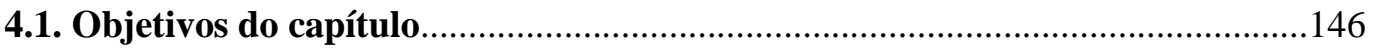

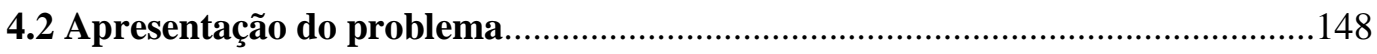

4.3 Os tipos de marcadores negativos nas línguas românicas: Zanuttini

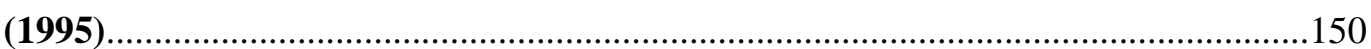

4.4 Restrições à negação em sentenças com imperativo verdadeiro.........................154

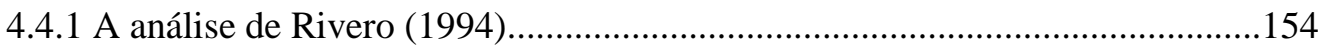

4.4.2 Força ilocucionária, escopo e negação: o problema semântico apresentado por Han (1999). 157

4.5 Os marcadores negativos no PB 
4.5.1 O estatuto clítico do marcador negativo pré-verbal no dialeto mineiro: a análise de Ramos (2006).

4.5.2 A projeção sintática do marcador de negação no PB no quadro teórico

Minimalista: a análise de Vitral (2006) .167

4.5.3 Características inovadoras da negação no PB: a dupla negação e a negação pós-verbal na análise de Biberauer; Cyrino (2009). .169

4.5.4. A negação em estruturas imperativas no $\mathrm{PB}$ . .174

4.6 Considerações finais do capítulo .177

CAPÍTULO 5 - CONSIDERAÇÕES FINAIS 179

REFERÊNCIAS BIBLIOGRÁFICAS. 


\section{INTRODUÇÃO}

Este trabalho tem por objetivo examinar aspectos sintáticos e semânticos de estruturas imperativas no português brasileiro (PB), fazendo-se a comparação com o português europeu (PE) e com outras línguas, com o objetivo de demonstrar que o PB possui uma configuração imperativa inovadora.

O comportamento morfossintático das sentenças imperativas foi analisado por diversos autores de orientação gerativista (Zanuttini 1991, 1994,1997, Rivero 1994, Rivero \& Terzi 1995). Segundo esses autores, a classificação proposta para as diferentes formas de expressar o modo imperativo pode ser estabelecida por meio de uma divisão em duas formas: a forma verdadeira e a forma supletiva.

A distribuição sintática das formas verdadeiras de imperativo é específica, diferindo das formas do modo subjuntivo e do indicativo. Já a forma supletiva é realizada com verbos que possuem morfologia advinda de outros modos como o infinitivo e, principalmente, o subjuntivo. Línguas como o espanhol e o grego apresentam, além de um paradigma imperativo próprio, uma sintaxe imperativa própria. As línguas que apresentam essa configuração são conhecidas como línguas de Classe I (cf. Rivero 1994). Já línguas como o servo-croata, o búlgaro e o macedônio são reconhecidas pela apresentação de um paradigma imperativo próprio, mas sem uma sintaxe específica ao modo imperativo. Essas línguas são apresentadas na literatura como línguas de Classe II. As diferenças no uso das formas verbais do modo imperativo geram repercussões importantes em outras configurações estruturais, com, por exemplo, na sintaxe da negação e na sintaxe do sujeito.

De acordo com a descrição gramatical, o PE possui as características das línguas de Classe I, pois possui formas verbais imperativas distribuídas em dois diferentes paradigmas: um paradigma com morfologia e sintaxe próprias à expressão do modo imperativo e uma forma supletiva, em que os verbos são realizados com morfologia advinda de outros modos como o infinitivo e, principalmente, o subjuntivo. Entre as características que definem o modo imperativo no PE estão, portanto, a restrição a marcadores negativos em sentenças com a forma verdadeira (*Não abre a porta!) e a restrição a sujeitos lexicalmente realizados em posição pré-verbal (*Tu/Você abre a porta!). ${ }^{1}$

\footnotetext{
${ }^{1}$ Agradeço ao Professor João Costa (c.p.), que me forneceu o julgamento de falante nativo do PE para a sentença no imperativo com sujeito lexical pré-verbal.
} 
As pesquisas sobre o modo imperativo no PB (cf. FARACO 1986, 1996; SCHERRE 2003, CARDOSO, 2004; 2009; SCHERRE 2007, SCHERRE ET AL. 2007, FERREIRA JUNIOR 2011, FERREIRA JUNIOR E SALLES 2013, 2015, 2016, entre outras) demonstram que as sentenças imperativas dessa língua não possuem morfologia própria à expressão desse modo, nem sintaxe imperativa própria. O modo imperativo no PB é expresso por meio de formas verbais que ocorrem em variação, com morfologia advinda de outros modos, como o subjuntivo e o indicativo, o que caracteriza uma situação de supletivismo (olhe/olha; abre/abra). Essa propriedade interage com o fato de que, no PB, não existe restrição ao uso de marcadores negativos no contexto dessas formas verbais (Não abrelabra a porta!), nem restrição à ocorrência de sujeitos em posição pré-verbal em contextos imperativos não marcados (Você abre/abra a porta!; Abre/Abra a porta!), sem excluir a possibilidade de sujeitos pós-verbais (Abre/Abra você a porta!), com interpretação marcada.

Além disso, é possível identificar no PB três formas distintas de realização da negação em sentenças imperativas - Neg-V; Neg-V-Neg; V-Neg, o que pode ser considerado uma inovação do $\mathrm{PB}$ (em relação ao $\mathrm{PE}$ ). Inovações como essas não podem ser reconhecidas em nenhuma das duas classes apresentadas por Rivero (1994). Tais fatos instigam à investigação sobre a configuração estrutural do modo imperativo no PB.

Um outro fator a ser analisado é a grande possibilidade de interpretações modalizadas nas sentenças imperativas do PB. Sentenças imperativas do PB possuem diversos matizes de polidez, que podem denotar uma ordem, um pedido, uma súplica entre outros. Isac (2015) aponta que sentenças imperativas supletivas apresentam maior grau de polidez que sentenças com a forma verdadeira. Essa característica estaria relacionada à diferença de posicionamento em que os verbos imperativos se situam na estrutura.

Diante das questões inicialmente apresentadas, pretendemos investigar como é formada a configuração sintática e semântica das sentenças imperativas no PB. Para isso, nossa hipótese é a de que a estrutura sintática das sentenças imperativas do PB apresenta um CP imperativo que possui em seu especificador um operador semântico optativo, cuja característica é o operador expressivo (EX) associado ao emissor no ato de elocução imperativo (cf. Grosz 2011). Esse operador representa uma expressão volitiva desiderativa implícita, que licencia a ocorrência da oração marcada pela 
modalidade optativa, o que permite ao emissor direcionar ao destinatário a mensagem imperativa com diferentes matizes, conforme citamos anteriormente.

Além disso, propomos que a configuração imperativa possui ainda a relação com a categoria ModP (Modality Phrase), que codifica a presença da segunda pessoa do discurso - o destinatário do ato de elocução da sentença imperativa, conforme originalmente proposto por Zanuttini (2008), e reformulado em Isac (2015). Assim, ao dispor em sua configuração posições para os dois participantes do ato de elocução imperativo, as sentenças imperativas do PB captam os dois eventos de causa do ato discursivo imperativo: (i) o primeiro, envolve o ato de elocução em que o emissor causa no destinatário a ação de fazer algo por meio da elocução imperativa e (ii) um outro componente que envolve a realização do comando dado pelo emissor ao destinatário que, por sua vez, pode fazer algo acontecer.

Nesse sentido, para desenvolver a argumentação, será primeiramente apresentada, no capítulo 1, uma caracterização translinguística do modo imperativo, passando-se à caracterização do PE e do PB. Em seguida, no capítulo 2, pretendemos demonstrar que as sentenças imperativas possuem um traço que representa um componente semântico modal. A presença desse traço justifica a necessidade de se projetar a categoria Modality Phrase (ModP) na estrutura sintática das sentenças imperativas. No capítulo 3, apresentaremos a hipótese a respeito da configuração estrutural das sentenças imperativas no português brasileiro (PB), considerando particularmente a hipótese da configuração imperativa optativa que inclui as projeções optativa e e diretiva. Por fim, no capítulo 4, apresentamos a análise sobre as estruturas imperativas negativas no PB, retomando estudos sobre a negação no $\mathrm{PB}$, em que se destaca o desenvolvimento da dupla negação e da negação pós-verbal, relacionando-se sua manifestação à sintaxe do imperativo no PB. No capítulo 5 apresentamos as considerações finais sobre o trabalho. 


\section{CAPÍTULO 1}

\section{ESTUDOS SOBRE O IMPERATIVO GRAMATICAL NO PORTUGUÊS BRASILEIRO}

\subsection{Objetivos do capítulo}

Este capítulo propõe-se fazer, inicialmente, a apresentação do quadro teórico de análise, para, em seguida, contextualizar o panorama empírico da pesquisa. Nesse sentido, apresentamos uma breve exposição sobre os pressupostos gerativistas e da teoria de Princípios e Parâmetros, conforme originalmente formulados em Chomsky (1986; 1995). A abordagem gerativista tem por objetivo explicar a natureza da linguagem humana pela hipótese da gramática universal (GU), que se define por princípios gerais, válidos para todas as línguas, e opções paramétricas, que correspondem às variações por elas apresentadas. Em seguida, faremos uma síntese dos estudos prévios que investigam o imperativo no português brasileiro, enfatizando os resultados obtidos em estudos variacionistas labovianos, que permitem conhecer as características dialetais e sociolinguísticas associadas às formas linguísticas presentes nas estruturas imperativas do PB.

\subsection{Quadro teórico}

1.2.1 Pressupostos teóricos: a faculdade de linguagem

Uma das características que distinguem os seres humanos é a capacidade de se comunicar de maneira complexa utilizando a linguagem verbal. Embora algumas espécies possuam sistemas de comunicação bastante complexos, é muito difícil comparar suas características à complexidade das línguas humanas.

As línguas humanas são sistemas sofisticados, capazes de detalhar informações de forma muito mais precisa que qualquer outra espécie. Nelas são relacionados som e significado de maneira sistematizada, o que permite realizar associações entre forma e 
conteúdo, ou seja, a forma das expressões linguísticas está relacionada à maneira com a qual vemos o resultado, quer sonoro, quer por meio de gestos visuais e o conteúdo relaciona-se ao valor informativo daquilo que se expressa. Seguindo a terminologia da literatura, adotaremos a distinção entre forma e conteúdo como ' $\pi$ ' e ' $\lambda$ ' respectivamente.

Ao observar a forma rápida e precisa como as crianças adquirem sua língua, uma curiosidade muito grande é gerada a respeito de como ocorre o processo de aquisição das línguas naturais. As correntes estruturalistas que dominavam o campo da linguística na primeira metade do século XX afirmavam que a língua era um componente socialmente constituído e compartilhado pela sociedade. Nesse sentido, a língua era adquirida por meio do contato e da observação. Essa concepção externalista, fundamentada também em princípios behavioristas, é, porém, confrontada com uma concepção internalista de língua, com a publicação em 1956, por Noam Chomsky, de uma resenha crítica, ao artigo Verbal Behavior, de Skinner, que defendia a hipótese behaviorista.

A diferença fundamental entre as abordagens externalista e internalista ou mentalista é a de que, nesta última, a língua não é mais concebida como um componente exclusivamente social e adquirida nesse contexto. A língua é considerada como um componente inato da cognição humana, um órgão mental responsável pela produção e compreensão das sentenças. Nesse sentido, ao desafiar as bases behavioristas presentes nos estudos linguísticos, Chomsky (1998:24) apresenta a tese central da teoria gerativa de que todas as línguas são "variações de um mesmo tema", ou seja, as línguas são sistemas inatos que se diferenciam minimamente uma das outras por meio de marcações paramétricas. São todas, assim, geradas por estruturas ou órgãos mentais.

A noção de gramática "gerativa" se dá pela propriedade de que esse órgão mental seja o gerador das expressões linguísticas das línguas humanas além de atuar como dispositivo de aquisição se língua. Nesse sentido, Chomsky assume a perspectiva internalista, em que a língua é constituída por propriedades 'internas' ao falante, fruto da capacidade inata do ser humano, referida como Faculdade de Linguagem.

Como pontos de apoio da concepção de uma gramática internalizada responsável pela geração e interpretação dos enunciados das línguas humanas, as bases gerativistas propõem que os falantes de uma língua possuem conhecimentos a respeito de sua língua materna representados na mente - língua-Interna. Por essa razão, são capazes de ter intuições a respeito da boa ou má formação das sentenças de sua língua . O componente 
interno responsável por esse conhecimento - a língua-I - constitui um sistema cognitivo, individual e intensional que integra as estruturas mentais. Essa língua interna, uma vez vinculada a uma situação de fala, ativa um sistema extensional - a língua externa.

A capacidade de gerar inúmeras sentenças por meio de um conjunto finito de itens (definido pelas propriedades estáveis da Gramática Universal) é uma das mais interessantes capacidades do sistema de comunicação humana, sendo referida como a criatividade linguística. A pergunta natural é: Como um falante poderia realizar uma sentença que nunca ouviu anteriormente? A produtividade da língua não alcançaria o grau de desenvoltura se fosse fundamentada apenas no aprendizado dos dados gerados externamente. A esse respeito, Chomsky (1981) defende que as línguas humanas são fruto de um aparato geneticamente determinado.

(...) dizemos que a criança aprende uma língua, e não que a linguagem se desenvolve ou amadurece. Mas nunca dizemos que o embrião ou a criança aprende a ter braços em vez de asas, ou um aparelho visual determinado, ou órgãos sexuais maduros - este último exemplo representa um desenvolvimento que consideramos ser geneticamente determinado no que tem de essencial, muito embora ocorra bem depois do nascimento.

(CHOMSKY 1981:177)

O objetivo da linguística de base gerativista é conhecer as bases gramaticais que concernem à estrutura das línguas humanas. Nesse sentido, o objeto de estudo gerativista se concentra na gramática universal e sua expressão em cada língua, "Língua I". Assim, com base nos dados das línguas existentes, Língua-E, vários teóricos têm investigado a hipótese da Gramática Universal, entendida como responsável por gerar e estruturar o conhecimento linguístico, bem como as diferenciações concernentes às línguas humanas.

Assim gramáticas particulares são formadas por princípios universais invariantes, além de requererem a fixação dos valores de uma série de parâmetros particulares associados a uma determinada língua, os quais são responsáveis pelas especificidades de cada língua. Essa abordagem está formulada na Teoria de Princípios e Parâmetros, um modelo que fornece bases para a investigação dos princípios que constituem o estado inicial da faculdade da linguagem, bem como os aspectos diferenciadores das línguas, que correspondem aos parâmetros das gramáticas particulares (cf. Chomsky 1986). 
Como exemplo dos princípios universais das línguas determinados pela Gramática Universal, podemos citar o Princípio da Projeção Estendida (Extended Projection Principle/EPP), que determina a presença obrigatória da posição de sujeito nas línguas. Esse princípio, no entanto, não determina que a posição de sujeito deva ser foneticamente realizada. Com isso, duas possibilidades são abertas: a realização fonética obrigatória do sujeito ou a possibilidade de se optar pela realização fonética ou não do sujeito. Dessa forma, associado ao EPP, identifica-se um parâmetro com dois valores, os quais dão origem a duas possibilidades: (i) línguas de sujeito nulo (+pro-drop), como o italiano, o espanhol e o português europeu e (ii) línguas em que o sujeito tem realização fonética obrigatória (-pro-drop), como o francês e o inglês.

A aquisição da língua é o resultado da interação das condições internas, ou seja, o estado mental inicial da faculdade de linguagem com o input, os dados externos, aos quais é exposto o aprendiz. A marcação paramétrica depende da exposição a uma dada língua, e ocorre até o momento em que se completa a aquisição da L1, alcançando-se o estado mental final. Com os desenvolvimentos da teoria, a noção de parâmetro passa a ser formulada em termos de traços formais que constituem os núcleos funcionais, conforme será discutido a seguir. A mudança linguística é vista como mudanças na distribuição e manifestação dos traços formais dos núcleos funcionais.

\subsubsection{O Programa Minimalista}

O Programa Minimalista não é uma nova proposta teórica sobre a linguagem, mas traz uma nova versão para o modelo de Princípios e Parâmetros, com novos pressupostos a respeito da estrutura da Gramática Universal (cf. CHOMSKY, 1995). Nesses termos, o Programa Minimalista desenvolve a hipótese de que a Gramática Universal possui um design perfeito, no sentido de que contém apenas o aparato essencial para satisfazer a realização da língua, tanto do ponto de vista conceitual quanto do ponto de vista articulatório.

De acordo com Chomsky (1995), a arquitetura da Faculdade da Linguagem compõe-se de duas partes: um léxico, de onde os itens que formarão as sentenças são retirados, e um sistema computacional, responsável por formar expressões a partir dos itens lexicais. Pela interação desses dois componentes, a informação é enviada para os sistemas de performance com os quais a língua apresenta interface, a saber, o sistema articulatório-perceptual (A-P) e o sistema conceptual-intensional (C-I). Esses sistemas 
têm como tarefa formar pares de objetos com propriedades fonéticas e semânticas, que serão enviados para os níveis de interfaces. A Forma Fonética (PF) é o nível de representação que faz interface com o sistema articulatório-perceptual. A Forma Lógica (LF) é o nível de representação que faz interface com o sistema conceptualintensional, conforme indicado no esquema a seguir.

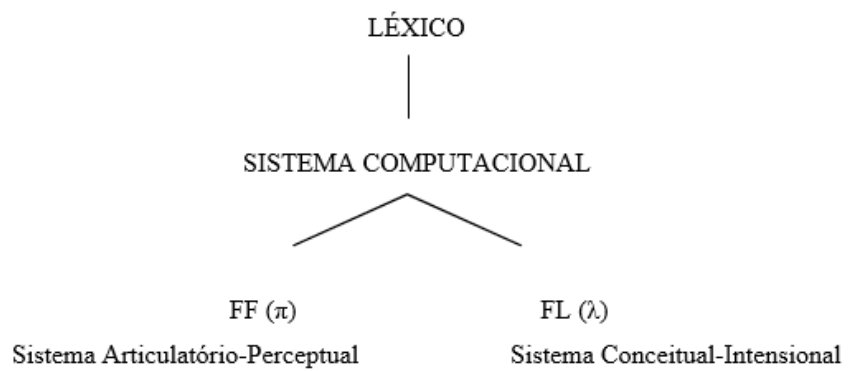

O Programa Minimalista prevê que os contrastes paramétricos entre as línguas se definem pelas especificidades dos itens lexicais, responsáveis pela ativação das operações computacionais. Os itens lexicais distribuem-se em categorias lexicais e funcionais, e se apresentam como um conjunto de traços fonéticos, semânticos e formais, a serem interpretados pela forma fonética e pela forma lógica. Os traços formais são utilizados nas operações realizadas pelo sistema computacional, para derivar as expressões linguísticas.

As operações do sistema computacional são realizadas em relação a um conjunto de unidades retiradas do léxico, e constituídas como um conjunto - a a Numeração cada uma com características específicas. São elas: Merge (concatenar), Move (mover), Copy (copiar), Agree (concordar) e Select (selecionar). Tais operações atuam de modo recursivo sobre o sistema, com a utilização de traços lexicais, e promovendo a criação das representações que serão interpretadas pelos sistemas A-P e C-I. Para que uma sentença seja 'lida' pelos sistemas de desempenho, as expressões geradas devem satisfazer o Princípio de Intepretação Plena, segundo o qual as condições gerais impostas pelos sistemas de interface devem ser satisfeitas plenamente.

Segundo esse princípio, só os traços interpretáveis em cada interface podem ser enviados pela computação para os módulos que fazem interface com a faculdade de 
linguagem. Por exemplo, a forma fonética (PF) é responsável apenas pelo comportamento dos traços fonéticos, e a forma lógica (LF) apenas pelos traços semânticos. Um traço não interpretável que tenha sido enviado a um desses níveis após a computação faz com que a derivação fracasse.

Na derivação de uma sentença, o primeiro passo é a seleção de itens lexicais. A partir de dessa seleção constitui-se uma numeração, que é submetida à computação, que, por sua vez, constroi objetos sintáticos. Essa construção se dá por meio das seguintes operações: 1. selecionar (select), responsável por retirar itens de numeração enviando para a derivação; 2. compor (merge), que agrega itens aos pares e, recursivamente, transforma-os em um novo objeto sintático; e, por fim, 3. mover (move), responsável por deslocar objetos sintáticos já formados para um alvo, formando um novo objeto.

Tais operações são submetidas a Agree, pela qual os traços formais não intepretáveis são eliminados/ valorados pelos traços formais intepretáveis correspondentes. A operação Agree pode ser realizada antes ou depois de Spell-out, que é ponto da derivação a partir do qual os traços da representação fonética são enviados para o sistema A-P. Sendo realizada antes de Spell-out, a operação Agree exige que a categoria dotada de traços formais intepretáveis seja realizada na posição de especificador do núcleo funcional que participa da operação Agree. Após Spell-out, a derivação é realizada na sintaxe encoberta, concluindo a representação na forma lógica (LF) a ser interpretada na pelo sistema C-I.

De acordo com as teses minimalistas, as propriedades paramétricas que diferenciam as línguas estão situadas nas propriedades formais dos itens lexicais, mais especificamente, dos itens funcionais do léxico.

\subsubsection{Categorias lexicais e categorias funcionais: o papel do núcleo $C$}

A noção de categoria lexical diz respeito ao grupo de palavras que apresenta conteúdo lexical, ou seja, palavras que possuem um valor de referência a algo no mundo. Nesse grupo é possível identificar verbos, adjetivos e substantivos. Uma categoria lexical tem a propriedade de selecionar semanticamente seus argumentos (seleção-s), além de manifestar propriedades de seleção de constituinte (seleção-c), pelo que são definidas suas propriedades na estrutura oracional. Por outro lado, a noção de categoria funcional diz respeito a palavras desprovidas de valor descritivo, isto é, palavras que possuem um valor estritamente funcional para o sistema linguístico, tais como preposições, conjunções e artigos. As categorias funcionais têm a propriedade de 
realizar apenas a seleção categorial (c-seleção), uma vez que não manifestam propriedades de seleção argumental.

Além disso, uma entrada lexical é constituída de três diferentes tipos de traços: formais, semânticos e fonológicos.

\begin{abstract}
Os traços formais podem ser identificados em duas formas distintas: os traços formais intrínsecos são determinados arbitrariamente pelo léxico, e os traços formais opcionais são especificados na realização da Numeração. No caso de airplane, as propriedades intrínsecas deste item incluem o traço categorial [nominal], o traço de pessoa [ $3^{a}$ pessoa] e o traço de gênero [-humano]. As suas propriedades opcionais incluem os traços não-categorias de número e Caso. As propriedades intrínsecas de build incluem o traço categorial [verbal] e o traço Casual [atribuir acusativo], mas os seus traços-f e o seu tempo são opcionais (CHOMSKY, 1999, p. 381)
\end{abstract}

Outra forma de distinguir os traços formais é por meio da natureza interpretável ou não interpretável desses traços. A esse respeito, Chomsky (1999) afirma que

\begin{abstract}
certos traços [...] participam nos processos interpretativos em LF, ao passo que outros não são interpretáveis, e têm de ser eliminados para obter convergência [...] Entre os traços Interpretáveis, encontram-se os traços categoriais e os traços- $\varphi$ dos elementos nominais [...] Assim, o traço opcional [ \pm plural] dos nomes é interpretável, logo não é eliminado em LF. Os traços Casuais de V e T são intrínsecos, mas -Interpretáveis, logo são eliminados em LF [...] Os traços Interpretáveis, assim, são ostraços categoriais em geral e os traços- $\varphi$ dos nomes. Os outros são -Interpretáveis. (CHOMSKY, 1999, p. $381)$.
\end{abstract}

Chomsky (1999) define, a partir dessas considerações, que tanto o Caso estrutural quanto a concordância (traços $\varphi$ ) são traços não interpretáveis. Por ser um traço de Caso um componente sintático, não apresenta condição de legibilidade em LF. Por esse motivo, o traço de Caso deve ser verificado anteriormente à realização do Spell-Out. Já os traços interpretáveis, permanecem como dados acessíveis no espaço derivacional e visíveis em LF.

A noção de categoria funcional, conforme visto anteriormente, diz respeito a categorias responsáveis por traços com valor estritamente funcional para o sistema linguístico. Em termos minimalistas, existem três tipos de categorias funcionais: D, T e C, que projetam respectivamente DP (Determiner Phrase), TP (Temporal Phrase), CP (Complementizer Phrase). Em nosso trabalho, discutimos em detalhe a natureza do CP imperativo no português brasileiro e as características que lhes são peculiares. Para isso, nesse momento deixamos a discussão das outras categorias funcionais e passamos exclusivamente à descrição do $\mathrm{CP}$, considerando os desenvolvimentos teóricos que 
buscam captar suas propriedades na interface com as funções discursivas, em que se sobrassai a força ilocucionária.

\subsubsection{O projeto cartográfico}

Cinque \& Rizzi (2008, p. 42) apresentam a proposta do projeto cartográfico como uma "tentativa de delinear mapas mais precisos e detalhados das configurações sintáticas". Os autores apresentam esse tópico de pesquisa paralelamente ao Programa Minimalista, tendo como principais fatores "a explosão de núcleos funcionais nos domínios verbal e nominal, que levou à cisão do CP e do DP. Essa cisão possibilita a identificação de propriedades ligadas à hierarquia do "limite superior da complexidade estrutural". Dessa maneira, os autores afirmam que ${ }^{2}$

\footnotetext{
"The logic of this argumentation [...] led to a finer splitting of the inflectional space into a sequence of functional heads expressing properties of mood and modality, tense, aspect, voice [...] One of the driving ideas of the cartographic projects was precisely to complement this trend of bottom-up, problemrelated discovery with a more top-down, global perspective, trying to make a rough estimate of the upper limit of the structural complexity." (CINQUE; RIZZI, 2008, p. 44)
}

A proposta dos autores marca o desenvolvimento teórico a respeito da periferia à esquerda das sentenças. A proposta da cisão do CP em outras categorias segue o curso de outras propostas que previam a cisão de outras categorias como o IP e o DP.

Em um trabalho anterior, Rizzi (1997:281) afirma que a representação da estrutura de uma sentença consiste em três camadas: (i) uma camada lexical, sendo o verbo o núcleo dessa camada, (ii) uma camada flexional, responsável pela atribuição de papéis théta e pela presença de especificações morfológicas concretas ou abstratas responsável pelo licenciamento de traços argumentais como Caso e Concordância e (iii) uma camada complementizadora, responsável pelo alojamento de morfemas funcionais e vários tipos de operadores, como pronomes interrogativos e relativos e elementos focalizados.

\footnotetext{
2 "A lógica dessa argumentação [...] levou a uma divisão mais fina do espaço flexional em uma sequência de núcleos funcionais que expressam propriedades de modo, modalidade, tempo, aspecto, voz [...] Uma das idéias motrizes dos projetos cartográficos foi precisamente complementar esta tendência de investigação do problema relativo à [derivação] bottom-up com uma perspectiva top-down mais global , tentando fazer uma estimativa aproximada do limite superior da complexidade estrutural.
} 
Rizzi (1997) parte do questionamento a respeito da importância do papel do Complementizador na estrutura oracional. ${ }^{3}$

We can think of the complementizer system as the interface between a propositional content (expressed by the IP) and the superordinate structure (a higher clause or, possibly, the articulation of discourse, if we consider a root clause). As such, we expect the $\mathrm{C}$ system to express at least two kinds of information, one facing the outside and other facing the inside.

(RIZZI 1997:283)

Rizzi aponta que o sistema Complementizador (doravante C) é responsável pela identificação do tipo de força ilocucionária que uma sentença expressa - a saber, declarativa, interrogativa, imperativa, exclamativa. Segundo o autor, essa força (F) é expressa tanto por elementos morfologicamente abertos hospedados no núcleo $\mathrm{C}$ ou mesmo pelo alojamento de operadores nulos na projeção CP. Para o autor, os elementos que fazem parte do sistema $\mathrm{C}$ determinam a interpretação da projeção que os aloja. Dessa maneira, Rizzi conclui que o sistema $\mathrm{C}$ atua como uma interface entre o conteúdo proposicional e a estrutura superordenada: este expresso pelo IP e aquele expresso por uma oração principal diante de uma oração subordinada que a acompanha.

Ainda no que diz respeito à expressão da força ilocucionária, Rizzi demonstra que, no núcleo $\mathrm{C}$ associado à força ilocucionária $(\mathrm{F})$, estão presentes complementizadores tais como 'that', do inglês. Além dessa propriedade, o autor demonstra que advérbios prepostos podem ser intervenientes entre um complementizador do tipo 'that' e um sujeito, mas não entre outros tipos de complementadores, tais como os preposicionais, e um sujeito, o que demonstra a relação entre o tipo de complementizador e a finitude.

(2) a. ... that John will leave tomorrow.

b. ...that, tomorrow, John will leave.

(3) a. ... for John to leave tomorrow.

b. *... for, tomorrow, John to leave.

(RIZZI 1997:301)

Os exemplos acima demonstram que a escolha do complementizador espelha especificações da categoria que o seleciona. Assim, Force aloja o complementizador

\footnotetext{
3 "O sistema complementizador pode ser entendido como uma interface entre um conteúdo proposicional (expresso pelo IP) e uma estrutura superordenada (uma oração mais alta ou, possivelmente, a articulação do discurso, se considerarmos uma oração raiz). Como tal, espera-se que o sistema $\mathrm{C}$ expresse ao menos dois tipos de informação, uma voltada para o exterior e uma para o interior."
} 
'that', o que permitirá a seleção de um verbo finito. Já na hipótese de um complementizador do tipo de 'for', o verbo deverá ser não finito, como (3a). Dessa maneira, a categoria ForceP selecionará verbos finitos e complementizadores do tipo de 'that' e a categoria FinP selecionará verbos não finitos e complementizadores do tipo de 'for'. No exemplo (3b) a agramaticalidade resulta de um verbo finito sendo acompanhado do complementizador preposicional 'for'. Conforme o exemplo anterior, Rizzi justifica a existência de duas naturezas distintas para complementizadores: uma categoria ForceP e uma categoria FinP subjacente a Force, o que resulta no chamado CP explodido.

Além de propor na periferia superior ao IP um sistema de projeções para alojar Força e Finitude, Rizzi (1997) também propõe a marcação de dois outros sistemas para a estrutura: Tópico e Foco. O tópico é anteposto, geralmente separado da oração por pausa/vírgula e tem como característica expressar informação já disponível no discurso ${ }^{4}$.

(4) Your book, you should give $t$ to Paul (not to Bill)

Seu livro, você deveria dar $t$ para Paul (não para Bill)

(RIZZI 1997:285)

Por outro lado, elementos focalizados são caracterizados por expressar informação nova.

(5) YOUR BOOK you should give t to Paul (not mine)

O SEU LIVRO, você deveria entregar $t$ para Paul (não o meu)

(RIZZI 1997:285)

No caso de elementos focalizados, há a anteposição do elemento, com acento focal, introduzindo uma informação nova.

Nas construções foco-pressuposição o foco é hospedado na posição de especificador e a pressuposição na posição de complemento. Já nas construções tópicocomentário, o tópico é hospedado na posição de especificador e o comentário é hospedado na posição de complemento. Comparando as duas relações (tópicocomentário e foco-pressuposição, Rizzi (1997) demonstra estruturalmente:

\footnotetext{
4 "The topic is a preposed element characteristically set off the rest of the clause by "comma intonation" and normally expressing old information, somehow available and salient in previous discourse; the comment is a kind of complex predicate, an open sentence predicate of the topic and introducing new information.” (RIZZI 1997:285)
} 
(6)

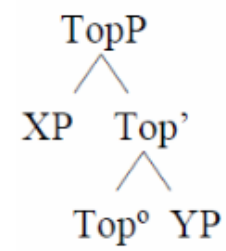

$\mathrm{X} \mathrm{P}=\mathrm{TOPIC}$

$\mathrm{YP}=\mathrm{COMENTARY}$

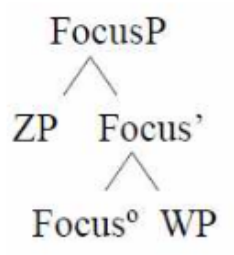

$\mathrm{ZP}=$ FOCUS

$\mathrm{WP}=\mathrm{PRESSUPOSITION}$

(RIZZI 1997:286,287)

Para Rizzi (1997), no sistema C, as categorias TópicoP e FocusP serão observadas na estrutura apenas se algum constituinte exibir as propriedades para a ativação dessas categorias. Caso essa ativação ocorra, essas categorias serão alocadas entre ForceP e FinP, conforme ilustrado na estrutura a seguir.

(7)

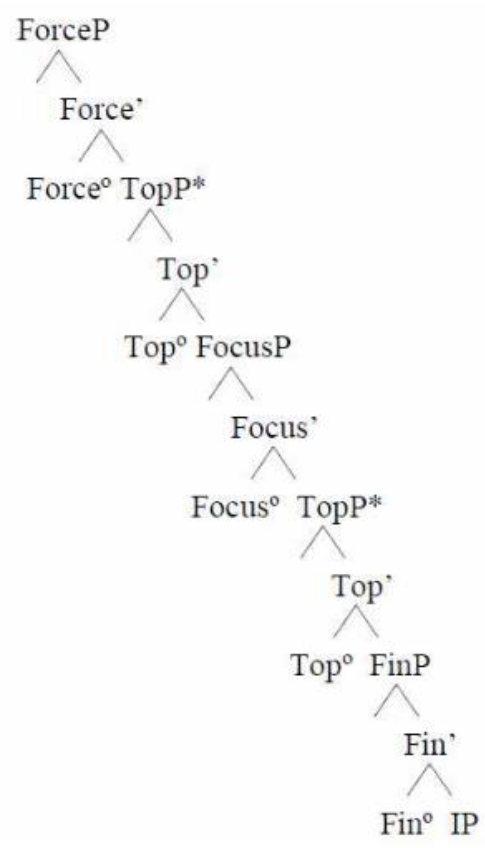

(RIZZI 1997:297) 
A proposta de Rizzi (1997) oferece importantes contribuições a respeito do entendimento das propriedades estruturais do CP. Entre essas propriedades, discutiremos especialmente a Força Ilocucionária, característica dos CP imperativos ${ }^{5}$.

\subsection{Apresentação do problema de pesquisa}

\subsubsection{Caracterização translinguística do modo imperativo}

Conforme registros da literatura gramatical, as línguas podem realizar de duas formas diferentes a oração imperativa. Uma delas é caracterizada por uma forma verbal própria ao modo imperativo, denominada imperativo verdadeiro. A outra não é específica ao modo imperativo, sendo realizada com formas advindas de outras formas verbais, como o subjuntivo e o indicativo, bem como de formas infinitivas ou gerundivas. A análise das línguas que apresentam imperativo verdadeiro identifica ainda dois grupos, em virtude de seu comportamento sintático. Assim, seguindo exposição em Rivero (1994) e Rivero; Terzi (1995), línguas que apresentam um paradigma imperativo próprio e sintaxe imperativa própria (como o espanhol) são classificadas como Classe I e línguas que apresentam um paradigma imperativo próprio, mas não apresentam uma sintaxe imperativa própria (como servo-croata, búlgaro e grego antigo), como Classe II.

Os exemplos ${ }^{6}(8 a)$ e (9a) representam a forma imperativa verdadeira, com morfologia distinta do modo indicativo, que não pode ser negada.

Imperativo verdadeiro

(8) a. Lee!

Ler.IMP.2P

'Lê!'

b. *No lee!

NEG ler.IMP.2P
(Espanhol Castelhano)

\footnotetext{
${ }^{5}$ Agradecemos ao professor Dr. Paulo Medeiros Junior e à professora Dra. Jânia Martins Ramos pelos questionamentos a respeito de, em nossa proposta, o CP se comportar como uma variante notacional do modelo de Rizzi (1997). Argumentamos que, em nossa análise, apresentamos um CP com propriedades não encontradas no modelo de Rizzi. Essas propriedades remetem à ontologia da categoria $\mathrm{CP}$ optativo, caracterizado por um operador EX nulo e pelo traço de primeira pessoa. Essa configuração seleciona a projeção da categoria Mod, que hospeda os traços de segunda pessoa e forma uma estrutura imperativa que exibe o contexto da elocução imperativa por meio de dois eventos distintos, conforme explicaremos no Capítulo 3.

${ }^{6}$ Os exemplos do espanhol castelhano, búlgaro e servo-croata são apresentados em Rivero (1994: 92) e os exemplos do grego moderno são apresentados por Rivero; Terzi (1995: 304).
} 
(9) a. Diavase!

ler-IMP-2P

(Grego moderno)

'Lê!'

b. *Den mi diavase!

NEG ler.IMP.2P

Diferentemente das sentenças com a forma verdadeira, os marcadores negativos ocorrem com o verbo na forma supletiva, a qual pode ser expressa pelo presente do subjuntivo, pelo indicativo e pelo infinitivo, conforme ilustrado nos exemplos de (10), (11), (12) e (13), do espanhol castelhano e do grego moderno.

Imperativo supletivo/ indicativo

(10) a. No leas!

NEG ler.IMP.2P

(Espanhol Castelhano)

'Não leias!'

b. No ler!

NEG ler.INF.2P

'Não ler!'

(11) Den diavases!

(Grego moderno)

NEG ler.PRES/IND.2P

'Não leias!'

Indicativo

(12) Tu lees!

(Espanhol Castelhano)

Tu ler.PRES/IND.2P

'Tu lês!'

(13) Diavases!

(Grego moderno)

Ler.PRES/IND.2P

'Tu lês!'

Rivero (1994: 92)

Além da diferença em relação à sintaxe da negação, existem diferenças em relação à sintaxe de clíticos pronominais. Os exemplos de (14) a (17) demonstram a diferença de realização do clítico em relação ao verbo, de acordo com o modo presente nas sentenças. No imperativo, o clítico ocorre em posição posterior ao verbo (ênclise) e, 
nos modos indicativo e subjuntivo, o clítico vem antes do verbo (próclise). Dessa forma, os dados que formam o paradigma que constitui as línguas que pertencem à Classe I contrastam com os dados que representam as línguas da Classe II.

Imperativo verdadeiro

(14) a. Léelo!

Ler.IMP=2Pclítico

'Lê-o!'

b. *Lo lee!

clítico ler-IMP-2P
(Espanhol Castelhano)

(Grego moderno)

(15) a. Diavase to!

Ler.IMP $=2 \mathrm{P}$ clítico

'Lê-o!'

b. *To diavase!

cl ler=IMP.2P

Indicativo

(16) a. Lo leiste!

2P=ler.IND. $2 \mathrm{P}$

'Tu o lês!'

b. *Leistelo!

Ler.IND.2P

(17) a. To diavases

(Grego moderno)

clítico ler.IND.2P

'Tu o leste!'

b. *Diavases to!

Ler $. \mathrm{IND}=2 \mathrm{P}$ clítico

(Espanhol Castelhano) 
Os exemplos de (18) e (19) demonstram a possibilidade da negação da forma verdadeira do imperativo nas línguas de imperativo verdadeiro Classe II, a seguir, o que caracteriza línguas da Classe II. Os dados em (20) e (21) demonstram o paradigma verbal do indicativo, confirmando a existência de um paradigma verbal com a forma verdadeira nas línguas de Classe II.

Imperativo verdadeiro

(18) a. Ceti!

(Búlgaro)

Ler.IMP.2P

'Lê!'

b. Ne ceti

NEG ler.IMP.2S

'Não lê!'

(19) a. Citaj!

(Servo Croata)

Ler.IMP.2P

'Lê!'

b. Ne citaj!

NEG ler.IMP.2P

'Não lê!'

Indicativo

(20) Cetes!

(Búlgaro)

Ler.PRES.2P

'Tu estás lendo!'

(21). Citas!

Ler.PRES.2P

(Servo Croata)

'Tu estás lendo!'

Rivero; Terzi (1995: 304)

A ordem entre o clítico pronominal e o verbo nas línguas de Classe II também contrasta com os dados das línguas de Classe I. Nos exemplos de (22) a (25), percebe-se que a realização do clítico é única, independentemente do modo verbal, ocupando 
sempre a posição de ênclise, em função de uma exigência prosódica da língua, de acordo com Rivero (1994:92;109;106):

Imperativo

(22) Ceti ja!

(Búlgaro)

Ler.IMP=2P clítico

'Lê-o!'

(23) Citaj je!

(Servo Croata)

Ler.IMP=2P clítico

'Lê-o!'

Indicativo

(24) Cetes ja!

Ler.PRES=2P clítico

(Búlgaro)

'Tu estás lendo-o!'

(25) Citas je!

Ler.PRES $=2 \mathrm{P}$ clítico

'Tu estás lendo-o!'

(Servo Croata)

Rivero; Terzi (1995: 304)

De acordo com Rivero (1994) e Rivero; Terzi (1995), nas línguas da Classe I, C abriga traços de modo para imperativo, enquanto nas línguas de Classe II, a categoria C não abriga esses traços. As autoras afirmam que, nas línguas de Classe I, o imperativo possui um traço equivalente a um operador modal que contribui para a determinação da força ilocucionária. Outras ideias antecedentes (Katz and Postal 1964, citados pelas autoras) incluem um morfema abstrato que subjaz à representação imperativa. Nesse sentido, a categoria $\mathrm{C}$ das línguas que seguem o padrão da Classe I possui especializações para o modo imperativo.

Ao contrário disso, as línguas de Classe II não têm uma sintaxe exclusiva para o modo imperativo, sendo os traços do verbo imperativo checados em I assim como os outros verbos da língua. Para discutir a proposta, as autoras citam a comparação entre os verbos do Grego Antigo (Língua de Classe II) e do Grego Moderno (Língua de Classe I). Os verbos imperativos no Grego Antigo podem ocupar a mesma posição que verbos no indicativo, optativo e subjuntivo. Dessa forma, postulam que Línguas de Classe II 
verificam o traço imperativo dos verbos em I, sem precisar de movimento para C. No entanto, os verbos de Classe II podem se movimentar para $\mathrm{C}$ em último caso, não por necessidade estrita de checagem em $\mathrm{C}$, porque seus traços são satisfeitos em I. Esse movimento de $\mathrm{V}$ para $\mathrm{C}$ nessas línguas ocorre apenas se não há um outro constituinte de primeira posição, o que significa que esse processo é sujeito à economia. Como consequência, os verbos das línguas de Classe II têm distribuição sintática independente, sem estabelecer relação com a forma lógica, a flexão do verbo ou marcas morfológicas de modo. Já nas línguas de Classe I, o imperativo é especial porque os verbos ocorrem na superfície em $\mathrm{C}$, estabelecendo uma correlação entre morfologia, intepretação imperativa e posição sintática. Nessas línguas, em razão de haver morfologia específica ao modo imperativo, a negação ocorre em associação com outros modos e formas verbais, em especial com o subjuntivo.

A checagem do traço imperativo, conforme as autoras apontam, segue o Greed Principle, proposto por Chomsky (1995) em que "move raises alpha only if morfological properties of alpha itself would not otherwise be satisfied in the derivation". [mover alça alfa somente se as propriedades morfológicas de alfa não forem satisfeitas na derivação de outra forma]. Em resumo, no caso das línguas de Classe I o verbo se move abertamente para a checagem em C, categoria que codifica os traços do imperativo. As línguas de Classe II realizam o modo imperativo com movimento para I, sem necessidade de checar os traços imperativos em C. Essa diferença de checagem dos traços implica diferenças na sintaxe do modo imperativo nas línguas de Classe I e II.

Os trabalhos de Rivero (1994) e Rivero \& Terzi (1995) são muito importantes no percurso da análise dos padrões de sentenças imperativas no quadro teórico gerativista. Nos próximos capítulos observaremos outras análises como a de Zanuttini (2008) e Isac (2015), que buscam explicar a sintaxe das sentenças imperativas. No entanto, ambas as análises seguem a direção de Rivero, no que diz respeito ao fato de que as diferenças entre sentenças com forma verdadeira e supletiva de imperativo diferem no que tange à categoria em que os traços são checados. As análises citadas ainda apresentam, semelhantemente aos trabalhos de Rivero (1994) e Rivero; Terzi (1995), que sentenças com a forma verdadeira são checadas em $\mathrm{C}$ e que sentenças imperativas supletivas são checadas em um núcleo inferior a $\mathrm{C}$ na estrutura.

Passamos ao estudo das sentenças imperativas no PB, em contraste com o PE. 


\subsubsection{O modo imperativo: PE versus PB}

\subsubsection{O português europeu}

Conforme a literatura a respeito do modo imperativo no PE, Cunha \& Cintra (1985: 464-471) e Mateus et al. (2003:449-460), apresentam duas características do imperativo verdadeiro, o que permite identificá-lo como uma língua da Classe I. A primeira característica é a existência de uma morfologia específica para a expressão desse modo, distinguindo-se do modo indicativo.

\section{Morfologia própria ao modo imperativo $x$ indicativo}

(26) a. Diz tudo! (imperativo, $2^{\mathrm{a}}$ pessoa, singular)

b. Dizes tudo. (indicativo, $2^{\mathrm{a}}$ pessoa, singular)

A outra característica é a ocorrência do imperativo verdadeiro exclusivamente em frases afirmativas, sendo agramatical a negação de sentenças com imperativo verdadeiro. Para a negação, assim como no grego moderno e no espanhol castelhano, a opção é o uso da forma supletiva (associada ao modo subjuntivo):
a. *Não diz a verdade! (Neg + imperativo verdadeiro)
b. Não digas a verdade! (Neg + imperativo supletivo)
c. Não dizes a verdade! (Neg + indicativo)

Em relação aos clíticos, o $\mathrm{PE}$ apresenta comportamento único, mas não exclusivo às sentenças imperativas: a posição é enclítica em todas as construções em que o verbo está na primeira posição. Uma forma de analisar essa restrição é considerar que esse fenômeno se deve a "um padrão geral relacionado à direcionalidade do apoio rítmico das cadeias pretônicas no português europeu, que são associadas a elementos precedentes ou à esquerda no fluxo do discurso" (CARVALHO, 1989, p.432-433 apud SCHERRE ET AL., 2007). ${ }^{7}$

\footnotetext{
${ }^{7}$ Existem inúmeras abordagens que discutem as mudanças observadas na sintaxe de pronomes objeto no português brasileiro. Não é objetivo deste estudo examinar tal fenômeno, o que nos leva a deixar em aberto a discussão quanto à proposta de Carvalho (1989), acima referida.
} 
(28) a. Diga-me a verdade!

b. *Me diga a verdade!

Em resumo, o modo imperativo no português europeu apresenta o imperativo verdadeiro, com morfologia distinta dos modos indicativo e subjuntivo. Também é caracterizado por uma sintaxe imperativa própria, em virtude de a negação não poder ser aplicada à forma verdadeira de imperativo. O uso do clítico em segunda posição, ou seja, em ênclise, também denota o mesmo padrão das línguas de Classe I, embora essa posição não seja restrita ao modo imperativo, sendo também aplicada ao indicativo e ao subjuntivo, o que difere da padronização das línguas de Classe I observadas, sendo, por outro lado, semelhante às línguas de Classe II.

\subsubsection{O português brasileiro}

A principal característica do imperativo no português brasileiro (PB) é o uso variável de duas formas verbais, sem distinção de pessoa.

(29) a. Abre a porta!
b. Abra a porta!
(imperativo)

Diferentemente das línguas de imperativo verdadeiro (Classe I), as sentenças imperativas no PB permitem que ambas as formas verbais sejam negadas, além se serem observadas diferentes estratégias de negação.

(30) a. Não/Num abre/abra o presente!

b. Não/Num abre/abra o presente não!

c. Não/Num abre/abra não o presente!

d. Abre/Abra não o presente!

e. Abre/ Abra o presente não!

f. (Não/num) abre/abra não o presente agora não!

Embora haja preferências dialetais aos usos das formas variáveis, um aspecto relevante é que não há nenhuma forma de restrição sintática à ocorrência dessas formas 
em contextos de negação. A análise dessas questões será desenvolvida no capítulo 4 desse trabalho ${ }^{8}$.

No que diz respeito à sintaxe dos clíticos pronominais, o PB permite tais elementos na posição inicial absoluta em orações imperativas diferentemente do PE, em que a ênclise no modo imperativo afirmativo é obrigatória. ${ }^{9}$

a. Me desculpe/ desculpa se falei demais.

b. Me traz um copo d'água!

Por fim, uma outra questão relevante na sintaxe imperativa do PB é a admissão de sentenças imperativas com sujeito em ordem SV e VS, com as formas verbais variantes presentes na estrutura imperativa.

a. Abre/Abra a porta!
a. Você abra a porta! (Ordem SV - forma supletiva SUBJ)
b. Você abre a porta!
(Ordem VS - forma supletiva IND)

(34) a. Abra você a porta! (Ordem SV - forma supletiva SUBJ)

b. Abre você a porta! (Ordem VS - forma supletiva IND)

O exemplo (32) apresenta a sentença imperativa sem ocorrência lexical do sujeito. Os exemplos em (33) possuem sujeito pronominal em posição pré-verbal. No entanto, a sentença com a forma verbal do indicativo (33b) apresenta ambiguidade com a leitura declarativa. No capítulo 3, defenderemos que essa sentença possui duas estruturas diferentes: uma declarativa e uma imperativa. Já os exemplos em (34)

\footnotetext{
${ }^{8}$ Agradecemos à Prof $^{a}$. Dr ${ }^{\mathrm{a}}$ Marta Scherre pelo questionamento a respeito da variação das formas associadas ao subjuntivo e ao indicativo em enunciados imperativos em relação à polidez. Reiterando nossa análise, ressaltamos que no $\mathrm{PB}$ as formas verbais ocorrem na mesma configuração sintática, independentemente da associação ao paradigma do indicativo ou do subjuntivo, o que se confirma pela uniformidade sintática em relação à presença de marcadores negativos e de sujeitos lexicalmente realizados, não havendo, portanto, contraste semântico. Consideramos igualmente relevante a observação da Professora Marta Scherre em relação ao papel de enunciados interrogativos na codificação da força ilocucionária imperativa no PB. Deixamos essa questão para investigação futura.

${ }^{9}$ De acordo com Carvalho (1989: 432-433), a sintaxe do clítico no PB está associada ao padrão prosódico da língua, que estabelece ligação do clítico com elementos pospostos ou à direita, enquanto no PE a impossibilidade dessa ocorrência se dá devido ao apoio rítmico das cadeias pretônicas. Deixamos para trabalho futuro a discussão acerca das condições que determinam a manifestação dos clíticos no PB e no PE nas sentenças imperativas.
} 
apresentam o sujeito pós-verbal. Nesse contexto, é realizada uma leitura contrastiva para uma interpretação de lista (abre/abra você a porta, não o João).

Essas diferentes configurações que os sujeitos de sentenças imperativas no PB exibem são, também, inovações que devem ser levadas em consideração na caracterização paramétrica do modo imperativo.

A próxima seção é dedicada a apresentar relações entre as formas variáveis dependentes e um conjunto de fatores identificados nos estudos variacionistas labovianos, com ênfase naqueles que propiciam um entendimento das questões gramaticais que desejamos abordar nesta tese. O objetivo é demonstrar que as variedades orais do PB não manifestam os mesmos padrões do PE em relação aos enunciados imperativos. Esse contraste é crucialmente associado à reanálise do sistema pronominal, a qual tem sido considerada um fator relevante no desenvolvimento do modo imperativo do PB, com implicações para a classificação proposta por Rivero (1994), conforme mencionado anteriormente.

1.3.2.3 A interação discursiva e a distribuição das formas do imperativo no português europeu e no português brasileiro

Com o objetivo de caracterizar o contraste entre o PE e o PB, em relação ao uso do imperativo, desenvolveremos uma discussão acerca das formas de tratamento no PB e de sua evolução como formas pronominais, atribuídas às transformações na estrutura da sociedade brasileira, tomando como referência a discussão desenvolvida em um conjunto de artigos produzidos por Marta Scherre e seu grupo de pesquisa em relação a esse tema.

Scherre (2008) observa que, no PE, as relações interacionais com menor distanciamento são formadas com o uso do imperativo verdadeiro, que é o contexto discursivo do pronome $t u$, o qual é caracterizado por controlar a ocorrência de traços da morfologia verbal em contextos de orações não imperativas, e também pelo uso do pronome possessivo teu.

(35). Junta-te ao clube!

Quando a relação interacional ocorre com maior distanciamento, utiliza-se o imperativo com a forma verbal supletiva, situado discursivamente no contexto do 
pronome você, conforme ilustrado em (35), extraído de um anúncio publicitário. Nessa ocorrência o verbo não manifesta traços morfológicos típicos das orações imperativas, sendo usada a forma supletiva (associada ao subjuntivo), e o pronome possessivo correspondente é o de terceira pessoa gramatical. Além disso, identifica-se a presença de vocativos que denotam menos intimidade.

(36). Poupe $50 \%$.

Enquanto, no PE, a associação entre as formas de imperativo está ligada aos contextos de maior ou menor distanciamento dos interlocutores, no PB, de acordo com dados da pesquisa de Scherre (2008), não parece haver uma relação estrita entre o uso das formas de imperativo e os contextos de menor ou maior distanciamento.

Segundo Faraco (1996:63), em Portugal, o uso do pronome 'tu' é de uso corrente no tratamento íntimo; já o uso do pronome 'você' se dá "entre iguais não-solidários e com interlocutores de status social inferior". No PB, essa distinção não é evidente e tem sido estudada por vários pesquisadores que analisam sua distribuição nas regiões do Brasil."

Ainda segundo Faraco (1996), o uso do pronome 'você' em contexto de tratamento íntimo no Brasil tem sua explicação na história da formação do país. O autor afirma que

\footnotetext{
"o uso da expressão 'Vossa Mercê' e de suas variantes era generalizado entre a população não aristocrática de Portugal, lugar de onde vieram os colonos que chegaram ao Brasil. Havia ainda uma crise de tratamento entre os falantes de classes financeiramente mais favorecidas, cujos integrantes, em geral, não emigraram para o Brasil. Considerando essas razões, é possível supor que o traço semântico de maior distanciamento, característico de Portugal, tenha se diluído em algumas regiões do Brasil. Esse evento pode estar relacionado também ao uso das formas imperativas no Brasil, uma vez que os contextos de distanciamento discursivo são correlacionados à expressão do imperativo. Assim, como resquícios do paradigma discursivo de maior distanciamento do PE, o uso de expressões do imperativo na forma subjuntiva predomina em alguns estados no PB". (FARACO 1996:63-64)
}

Em estudo anterior, Faraco (1986) conclui que a mudança no sistema de tratamento no PB é uma evidência de que mudanças sociais podem desencadear mudanças linguísticas e que estas, por sua vez, desencadeiam uma série de outras mudanças internas.

Um outro apontamento importante apresentado por Faraco neste estudo diz respeito à questão de a forma verdadeira de imperativo ser uma forma indicativa com 
valor de atos de fala impositivos. Em sua análise, argumenta que, de um ponto de vista sintático, esses atos de fala são caracterizados pela ausência de sujeito superficial. No que diz respeito aos aspectos fonológicos, são sentenças caracterizadas por um padrão entoacional descendente. Em terceiro lugar, a respeito das características semânticas, o autor afirma que essas sentenças possuem a capacidade de expressar ordens, pedidos, sugestões, súplicas etc. Faraco conclui que essas formas indicativas com valor impositivo são, de fato, imperativas.

Considerando-se que a forma do indicativo é utilizada como parte de um paradigma imperativo, a alternância das formas de imperativo e indicativo independe do tipo de contexto interacional. Uma das possíveis razões é o processo de reanálise do sistema pronominal no português brasileiro, em que a forma de tratamento 'você' é gramaticalizada como pronome de segunda pessoa. Uma das razões para essa reanálise, segundo Faraco (1986:5), tem base diacrônica. A queda do -t final da terceira pessoa do singular do presente do indicativo latino provocou uma homonímia entre essa forma verbal e a forma do imperativo associado ao indicativo - a segunda pessoa do singular, conforme ilustrado abaixo. Assim, o resultado dessa homonímia é visto atualmente no $\mathrm{PB}$, conforme (37)

(37)
a.O pai canta a música.
(indicativo)
b.Canta a música!
(imperativo)

Com a gramaticalização da forma de tratamento 'você' no paradigma pronominal, essa categoria passa a selecionar a forma verbal da terceira pessoa, o que causa uma confluência das formas verbais de segunda e de terceira pessoa.

$$
\begin{aligned}
& \text { (38) a. Tu fazes - Pron. } 2^{\mathrm{a} P S}+\mathrm{V} 2^{\mathrm{a} P S} \\
& \text { b. Ele faz - Pron. } 3^{\mathrm{a} P S}+\mathrm{V} 3^{\mathrm{a} P S} \\
& \text { c. Você faz - Pron. } 2^{\mathrm{a} P S}+\mathrm{V} \mathbf{3}^{\mathrm{a} P S}
\end{aligned}
$$

O resultado dessa confluência é o uso do pronome de terceira pessoa 'você', em contexto discursivo de segunda pessoa do singular. Conforme é possível observar nos exemplos, há uma situação de sincretismo morfológico entre as formas do imperativo e do indicativo, sem realização da forma verdadeira de expressão do modo imperativo. 
(39) Senta aqui perto, pai!

(imperativo)

(40) O pai/ Você senta perto do menino. (indicativo)

1.3.3 Variação linguística e mudança paramétrica no imperativo do português brasileiro

\subsubsection{Fatores linguísticos associados à variação}

Nesta seção, apresentam-se resultados de estudos sociolinguísticos acerca da variação no uso das formas verbais do imperativo no português brasileiro com o objetivo de investigar o papel dos fatores linguísticos e extralinguísticos no uso variável dessas formas verbais. Para tanto, tomamos como referência primordialmente os textos Scherre (2003), Cardoso (2004; 2009), e Scherre et al. (2007), em que são apresentados fatores como o tipo de pronome, na relação com o contexto discursivo, a polaridade da sentença, bem como o papel do paralelismo sintático no processo de variação linguística, além da distribuição regional. ${ }^{10}$

Scherre (2003) parte da observação de que, no português brasileiro contemporâneo, o uso do imperativo gramatical pode variar, no mesmo contexto discursivo, entre duas formas: o imperativo associado ao indicativo, com formas do tipo 'fala', 'abre', 'faz' e o imperativo associado ao subjuntivo, com formas como 'fale', 'abra', 'faça'. O estudo orienta-se para textos de revistas em quadrinhos, em que se verifica a ocorrência do discurso direto e uma incidência maior de frases imperativas. No estudo dos condicionamentos linguísticos, a autora constata a relevância de fatores como a polaridade da sentença, a presença de pronomes, presença/ausência de vocativos, além de fazer referência a fatores dialetais.

Scherre et al. (2007) levantam a hipótese de que, na ausência de uma forma verdadeira para a expressão do imperativo, as formas do indicativo e do subjuntivo no $\mathrm{PB}$ ocorrem em contexto de variação na expressão do modo imperativo no $\mathrm{PB}$, o que permite afirmar que o imperativo nessa língua é formado exclusivamente por formas verbais supletivas.

10 Questões relacionadas aos aspectos fonológicos não serão consideradas. Por indicação de Marta Scherre (c.p.), remetemos o leitor ao estudo Scherre et al. (1998) Evidence from the Imperative in Brazilian Portuguese. In: (orgs) PARADIS, C. et alii. Papers in Sociolinguistics. NWAVE26 à l'Université Laval (Québec): Nota Bene, p. 63-72. Agradecemos à Profa. Marta Scherre a indicação desse texto, além de outros que estão citados indiretamente nesta seção. 
A esse respeito, Scherre (2007) apresenta um interessante mapeamento da expressão variável do imperativo em regiões do Brasil. Esse mapeamento considera a fala espontânea do PB em várias regiões entre as décadas de 70 a 90. Nesse mapeamento, Scherre divide os dados em dois grupos: o primeiro grupo com dados de formas imperativas associadas ao paradigma indicativo e o segundo com formas associadas ao paradigma subjuntivo.

A pesquisa revela que os dados com a forma imperativa associada ao indicativo são predominantes na região Centro-Oeste, Sul e Sudeste. Na região Nordeste, por outro lado, é atestada maior frequência da forma imperativa associada ao subjuntivo ou o equilíbrio das duas formas, conforme o gráfico apresentado a seguir.

Tabela 1.1 Distribuição do imperativo gramatical no eixo geográfico

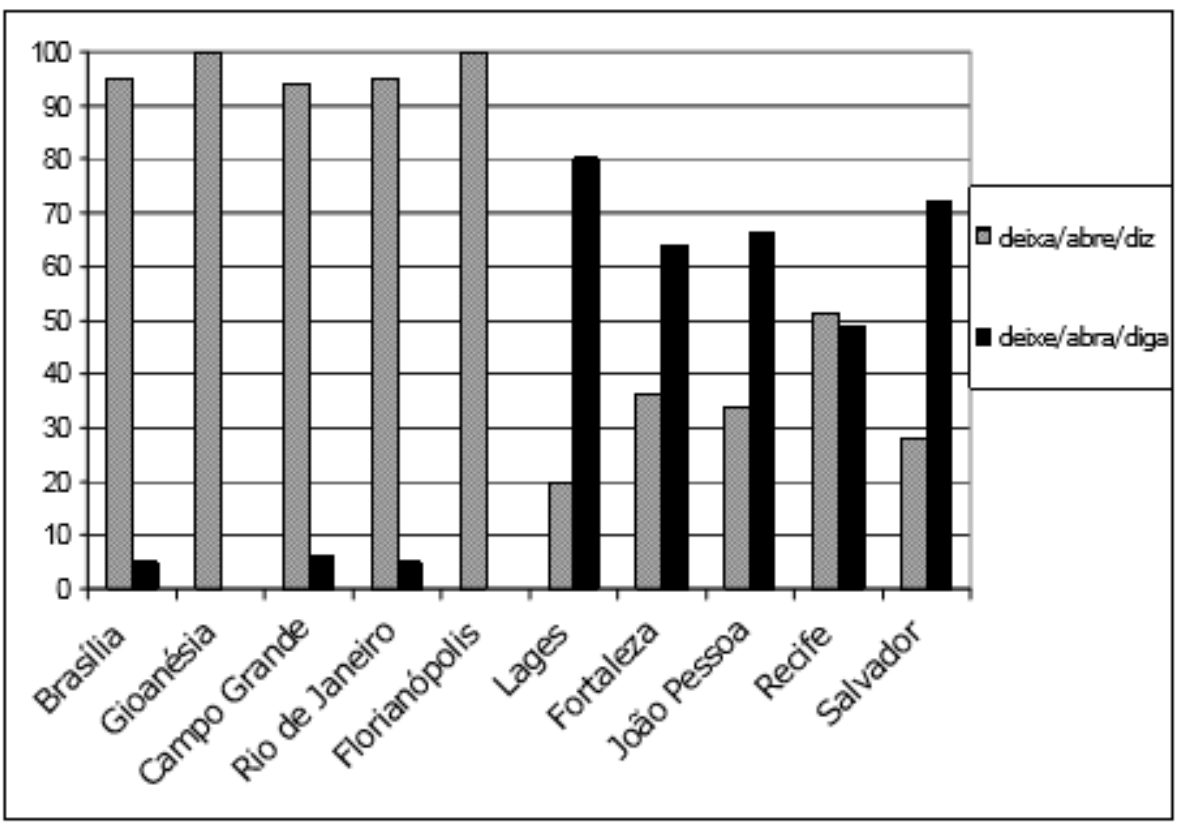

(SCHERRE 2007:194)

De fato, estudos mostram que existem condicionamentos geográficos para a ocorrência das formas variáveis do imperativo: nas regiões Centro-Oeste, Sudeste e em parte da região Sul, predomina o uso do imperativo associado ao indicativo, enquanto na região Nordeste, em cidades como Salvador, João Pessoa, Recife e Fortaleza predomina o uso do imperativo associado ao subjuntivo (cf. Sampaio 2001, citado por Scherre 2003; Alves, 2001; Jesus, 2006; Cardoso, 2006, citados por Cardoso, 2009).

Jesus (2006) retoma essa questão, ressaltando que os estudos evidenciam que já existe uma leve tendência de aumento na frequência de uso do imperativo associado ao 
indicativo em regiões onde predomina o uso do imperativo associado ao subjuntivo. Além disso, a autora observa que a tendência de aumento na frequência de uso do imperativo associado ao indicativo se dá em função da faixa etária e do aumento da escolaridade: os mais novos e os mais escolarizados tendem a usar mais o imperativo associado ao indicativo.

A observação de Jesus vem confirmar os resultados de outras pesquisas sobre a variação do imperativo no português brasileiro (cf. Scherre 2003; 2004, 2007, 2008; Scherre et al. 2007). Essas pesquisas têm revelado que a alternância entre as formas variantes não tem correlação clara com a presença dos pronomes 'tu' ou 'você' no contexto discursivo, inversamente ao que se observa no português europeu, em que a presença desses pronomes marca traços de [+] ou [-] distanciamento, os quais, por sua vez, estão codificados no sistema pronominal e nas formas de tratamento (cf. Cardoso, 2004; Lima, 2005; Jesus, 2006, citados por Cardoso, 2009). Ampliando a investigação a respeito dos fatores linguísticos que motivam a variação no uso do modo imperativo no PB, Cardoso (2009) acrescenta fatores como a sintaxe dos clíticos, além de retomar com mais detalhe a questão da reanálise do sistema pronominal (redução do paradigma verbal), a sintaxe da negação, a presença/posição de elementos pronominais na estrutura do discurso.

Em relação ao paralelismo discursivo, Cardoso (2009) afirma que tal fator consiste em identificar, em uma sequência de orações, a interferência de uma forma precedente sobre a forma subsequente. Segundo a autora, os resultados mostram que há um condicionamento linguístico no plano do discurso, motivado pelas formas precedentes, ou seja, o uso do imperativo associado ao indicativo numa sequência discursiva favoreceria o emprego de outra forma associada ao indicativo. Da mesma forma, o uso do imperativo associado ao subjuntivo favoreceria outra forma subjuntiva.

A outra variável selecionada é denominada "polaridade da estrutura". Ela envolve três aspectos: a polaridade afirmativa e negativa da estrutura; a presença ou a ausência de pronomes no contexto e o tipo de pronome: tu/ teu ou vocêl seu no contexto. Por meio dessa variável, verifica-se a relação entre o registro da tradição gramatical para o imperativo afirmativo e negativo, e o uso na língua falada e escrita. As pesquisas demonstram diferentes percentuais em relação à realização das formas variáveis, no uso das estruturas afirmativas e negativas.

Os exemplos a seguir, extraídos de Cardoso (2009: 41), ilustram a variação em relação ao registro da tradição gramatical: em (41), vê-se uma estrutura afirmativa com 
o uso de imperativo na forma indicativa em contexto de pronome 'você'. O exemplo (42) apresenta a negação sentencial com o uso do imperativo na forma indicativa.

(41) - DEIXA eu ver - disse ele procurando-me na sombra. (exemplo de língua escrita, retirado de Veiga, 1998:83)

(42) Não ATRASA a boiada. (exemplo de língua escrita, retirado de Veiga, 1994:152)

A esse respeito Cardoso (2009:41) comenta:

\begin{abstract}
"Essa alternância no uso de imperativo associado ao indicativo e de imperativo associado ao subjuntivo em estruturas imperativas afirmativas e negativas acontece tanto na fala quanto na escrita (...) Contudo, a tendência verificada é de imperativo afirmativo favorecendo mais o uso de formas como 'leva', 'faz', 'vem' e imperativo negativo favorecendo mais formas como 'leve', 'faça', 'venha'. Segundo Scherre (2003:180), esse efeito evidencia paralelismo semântico, visto que o uso do subjuntivo está associado ao modo irrealis, combinando-se mais com a polaridade negativa".
\end{abstract}

O trabalho de Sampaio (2001) apresenta evidências que confirmam esse efeito. Ao apresentar dados do Rio de Janeiro, cidade em que predomina o uso de imperativo associado ao indicativo, Sampaio afirma que a polaridade negativa da estrutura favorece o uso de imperativo associado ao subjuntivo.

Assim, enquanto em estruturas imperativas afirmativas, 95\% dos usos são realizados com a forma associada ao indicativo, em estruturas com a negação, o percentual cai para 78\%. Dessa maneira, para Sampaio (2001), essa tendência ocorre por causa da possibilidade de preenchimento do sujeito, como poderia ocorrer nos exemplos do par "não jogue/não joga", sendo que o segundo exemplo permite a possibilidade da leitura "você não joga".

Outro fator investigado é o tipo, a posição e a pessoa dos pronomes oblíquos. A presença do pronome oblíquo 'se' ou 'me' depois do verbo (em ênclise) favorece categoricamente o uso do imperativo na forma subjuntiva, como ocorre em "cale-se". De acordo com Cardoso (2009), isso ocorre porque o uso de imperativo associado ao indicativo - como em "cala-se" levaria ao preenchimento de um sujeito de $3^{\mathrm{a}}$ pessoa, deixando de assegurar uma leitura imperativa. Por outro lado, a mudança de posição do pronome para antes do verbo (próclise) favorece o uso variável do imperativo, visto que não bloqueia a leitura imperativa, conforme ocorre em "se coloca no meu lugar". A autora nesse ponto não leva em consideração o fato de que o preenchimento da posição 
de sujeito não bloqueia a leitura imperativa, mas apenas favorece a ambiguidade entre uma leitura declarativa e imperativa (uma questão que retomaremos adiante).

Outros resultados em relação ao tipo e à posição de pronomes são comentados pela autora. ${ }^{11} \mathrm{O}$ pronome oblíquo 'me' proclítico ou a ausência de pronome favoreceriam o uso de imperativo associado ao indicativo, como em (43). Já o pronome oblíquo 'se' proclítico, em (44), favoreceria uso do imperativo associado ao subjuntivo. Isso ocorreria pela possibilidade de perda da leitura imperativa.

(43) - Me DIZ uma coisa - Disse Simão interrompendo. (VEIGA, 1995:54)

(44) E se VISTA para o cemitério se tiver vontade de fofocar.

Retomando a análise de Scherre (2003), vemos que a autora afirma que, além da possibilidade da perda da leitura imperativa das sentenças, caso o verbo seja usado na forma associada ao indicativo, nos casos descritos acima, há outro aspecto a ser considerado para a interpretação da variável que analisa os clíticos: a coexistência de formas que refletem momentos linguísticos diferentes. $\mathrm{O}$ fato de pronomes oblíquos enclíticos favorecerem o imperativo associado ao subjuntivo mostra um reflexo da língua portuguesa falada em outro momento no Brasil. Já o uso do pronome pessoal do caso reto, conjugado ao uso do imperativo associado à forma indicativa, corresponde ao uso atual que se estabelece nas regiões Sul, Sudeste e Centro-Oeste. Nos dados de Scherre (2003), a ocorrência de pronome do caso reto depois do verbo em estruturas imperativas favorece categoricamente o imperativo na forma indicativa.

Em nossa análise, consideramos que as questões associadas à variação linguística dos usos do indicativo e do subjuntivo para expressar o imperativo no PB, inclusive as questões relacionadas ao favorecimento de ocorrência das formas do indicativo ou do subjuntivo em contextos de imperativo são questões exclusivamente dialetais e, por esse motivo, não acarretam consequências para a estrutura sintática do imperativo no PB.

\subsection{Considerações finais do capítulo}

Este capítulo teve como objetivo apresentar os objetivos do presente estudo, bem como as hipóteses que orientam a investigação das características das estruturas

11 Cardoso (2009:42) Exemplos retirados de NURC/RE citado por Jesus (2006). 
imperativas no $\mathrm{PB}$, considerando particularmente a interação entre as formas verbais do imperativo e a sintaxe da negação. Para isso inicialmente apresentamos o quadro teórico que fundamenta a pesquisa: a teoria gerativa, em que foram apontados os pressupostos estabelecidos na formulação da teoria de Princípios e Parâmetros, conforme formulada em Chomsky (1986; 1995, e estudos subsequentes). Na formulação do problema da pesquisa, partimos dos estudos prévios que investigam as línguas com imperativo verdadeiro (classe I e classe II), em que se inclui o PE, em oposição ao PB. Para o estudo sobre a variação paramétrica do modo imperativo no PB em relação ao PE, foram apresentados os trabalhos de Scherre (2003; 2007; 2008); Scherre et al. (2007) e de Cardoso (2004; 2009) em que são apresentadas características relevantes concernentes à realização do modo imperativo no PB. Após a análise do modo imperativo nessas duas línguas, fica evidente que a compreensão sobre o funcionamento da modalidade e sua expressão nas estruturas imperativas, bem como das propriedades da negação é fundamental para o estudo das propriedades formais das inovações que o modo imperativo desenvolveu no PB. No próximo capítulo será apresentada a justificativa para a existência de uma categoria de modalidade na estrutura imperativa. Defendemos que as sentenças imperativas possuem um traço que representa um componente semântico modal. A presença desse traço justifica a necessidade de se projetar a categoria Modality Phrase (ModP) em sua sintaxe. Essa categoria aloja traços de segunda pessoa e marca o posicionamento do destinatário do ato de elocução imperativo. 


\section{CAPÍTULO 2 \\ MODO, MODALIDADE NA ESTRUTURA IMPERATIVA}

\subsection{Objetivos do capítulo}

O objetivo desse capítulo é demonstrar que as sentenças imperativas possuem um traço que representa um componente semântico modal. A presença desse traço justifica a necessidade de se projetar a categoria Modality Phrase (ModP) na estrutura sintática das sentenças imperativas. Para isso, inicialmente apresentaremos as noções de modo gramatical e modalidade no âmbito das gramáticas tradicionais de língua portuguesa no Brasil, considerando-se que tais noções estão subjacentes à descrição das estruturas imperativas proposta nessas obras. Na sequência, será realizada uma revisão na literatura de orientação gerativista, verificando as contribuições de autores a respeito do tema. Tomamos por referência primordialmente o estudo de Isac (2015), no sentido de avaliar o papel da categoria modalidade na estrutura oracional de orações imperativas, tendo em vista o objetivo de verificar a hipótese de uma estrutura que possibilite marcar as sentenças imperativas com um traço de modalidade na estrutura sintática. Após a revisão da literatura, apresentaremos nossa proposta para tais orações, em que buscamos contemplar as características das sentenças imperativas no PB. Nessa abordagem, postulamos que as sentenças imperativas no PB possuem uma categoria responsável pelos traços de modalidade em uma posição relativamente alta na estrutura, logo abaixo de CP, o que permite a existência de diversos matizes de modalidade (deôntica, bulética, exortativa, desiderativa, rogativa, entre outras) associadas às sentenças imperativas. Reiteramos que as matizes de modalidade nas sentenças imperativas no PB são justificadas pela existência de um CP diretivo-optativo, em compatibilidade com a categoria ModP, associada aos traços de modalidade. 


\subsection{Modo, modalidade e a hipótese da projeção ModP}

A tradição gramatical descritivista, inspirada na filosofia escolástica, determina dois componentes na construção dos enunciados: o dictum - aquilo que é objeto da comunicação - e o modus - atitude ou ponto de vista do enunciador relativamente ao objeto de sua comunicação (AZEREDO, 2008). A expressão do modus é realizada de várias maneiras. Uma delas consiste em variar a entoação da frase para exprimir certeza, admiração, dúvida, ceticismo etc. Também pode se recorrer a verbos que expressam atitudes, como saber, duvidar e supor, e a advérbios, como talvez, sinceramente, obviamente etc. Trata-se de recursos de modalização ou modalidade.

Ao produzir um enunciado, o falante inscreve nele, portanto, algumas marcas que servem para balizar a compreensão a ser realizada pelo interlocutor, como pode ser visto nos exemplos abaixo:

(1) a.Vocês podem sair agora. (permissão)

b.Vocês precisam sair agora. (obrigatoriedade)

$\mathrm{Na}$ descrição da gramática tradicional, modo é uma categoria gramatical, em geral associada ao verbo, e que traduz o tipo de comunicação instituído pelo falante entre ele o seu interlocutor, ou entre o falante e os seus próprios enunciados. Considerando os estudos gramaticais voltados para a descrição de línguas ocidentais como o português, distinguem-se os modos imperativo, indicativo e subjuntivo. No discurso, os modos verbais estão associados à modalidade, a qual está relacionada à noções de verdade ou realidade e seu antagônico, referido como irrealis. Ainda neste capítulo veremos detalhadamente as relações estabelecidas entre modo e modalidade. No entanto, primeiramente, passaremos a observar como as gramáticas tradicionais brasileiras apresentam a noção de modo.

2.2.1 A noção de modo e modalidade: a perspectiva das gramáticas tradicionais

A tradição da gramática apresenta o modo verbal como a propriedade que o verbo tem de indicar a atitude da pessoa que fala em relação ao fato enunciado. Essa atitude do falante em relação ao fato enunciado é realizada de três diferentes maneiras, 
por meio dos modos indicativo, subjuntivo e imperativo. A diferença entre as formas de expressão desses modos é marcada morfologicamente.

Cunha \& Cintra (2001:448) caracterizam o modo indicativo como o modo que exprime uma ação ou um estado considerado na sua realidade ou na sua certeza, quer em referência ao presente ao passado ou ao futuro. Apresentam ainda o modo subjuntivo como uma forma incerta, duvidosa, eventual ou mesmo irreal de observar a existência ou não de um fato. Por fim, o modo imperativo é apresentado pelos autores como o modo da exortação, do conselho, do convite, e não de ordem ou comando.

Embora a palavra IMPERATIVO esteja ligada, pela origem, ao latim imperare "comandar", não é para ordem ou comando que, na maioria dos casos, nos servimos desse modo. Há, como veremos, outros meios mais eficazes para expressar tal noção. Quando empregamos o IMPERATIVO, em geral, temos o intuito de exortar o nosso interlocutor a cumprir a ação indicada pelo verbo. É, pois, mais o modo da exortação, do conselho, do convite, do que propriamente do comando, da ordem. (CUNHA \& CINTRA 2001:477)

Ainda sobre o imperativo, Cunha \& Cintra (2001) apresentam duas formas para a expressão desse modo no português: um afirmativo e outro negativo. O imperativo afirmativo caracteriza-se por possuir formas próprias somente para as segundas pessoas do singular e do plural (sujeito 'tu' e sujeito 'vós'). O imperativo negativo não possui forma própria e é "suprido pelo presente do subjuntivo" (Cunha \& Cintra 2001:476). Os autores ainda observam que, em razão de o modo imperativo ser caracterizado pela direção da fala de um indivíduo a um interlocutor, só admite as segundas pessoas do singular e do plural e as terceiras pessoas do singular e do plural, quando o sujeito é expresso por pronome de tratamento como você, o senhor, Vossa Senhoria etc.

É interessante observar que os autores distinguem certas formas do presente do subjuntivo de formas imperativas.

(2) a. Caiam de bruços" (imperativo)

b. Caiam sobre vós as bênçãos divinas! (subjuntivo)

(CUNHA \& CINTRA 2001:476)

Os autores diferenciam, por meio dos exemplos (2a) e (2b), o imperativo como associado à expressão da ordem, ou da exortação, e o subjuntivo, como associado à expressão do desejo. Verifica-se, no entanto, que a distinção realizada pelo autor é 
contraditória em relação à própria citação, transcrita anteriormente. Ao afirmar que o imperativo "é mais o modo da exortação, do conselho, do convite, do que propriamente do comando, da ordem", não se torna claro o motivo da distinção realizada no exemplo acima. Assim, observa-se que a definição dos autores para o imperativo é deficiente. No entanto, a definição de Cunha pode ser ressignificada na possibilidade de apresentar uma espécie de gradação nas sentenças imperativas, que varia desde ordem/exortação a um outro extremo de conselho/convite/súplica. Em nosso trabalho, também atribuímos essa espécie de gradação às estratégias disponibilizadas pelas diferentes modalidades na expressão do imperativo no PB. Conforme mencionado anteriormente, nossa hipótese é a de que as diferentes estratégias de uso das modalidades são muito comuns nas sentenças imperativas no $\mathrm{PB}$ e isso se dá em razão das propriedades estruturais das sentenças imperativas nessa língua.

Bechara (2003:275) apresenta o modo indicativo como o modo que normalmente aparece nas orações independentes e nas dependentes que apresentam um fato real ou tido como tal. Já o modo subjuntivo é apresentado pelo autor como o modo que ocorre normalmente em orações independentes optativas, nas imperativas negativas e afirmativas (apesar de observar como exceções a segunda pessoa do singular e do plural); nas dubitativas, caracterizadas pela presença do advérbio 'talvez' e nas subordinadas, em que o fato é considerado como incerto, duvidoso ou impossível de se realizar. É interessante observar a associação realizada pelo autor entre os modos e a sintaxe. Sua conceituação já demonstra a percepção de uso do imperativo negativo associado ao modo subjuntivo, sem, no entanto, aprofundar a questão. Também cita a associação entre o subjuntivo e orações optativas, atribuindo às optativas o estatuto de orações independentes.

(3) a. Não emprestes, não disputes, não maldigas e não terás de arrepender-te.

b. Bons ventos o levem!

(BECHARA 2003:280)

No entanto, o autor assume apenas a noção de modo, distribuindo as ocorrências entre cinco tipos distintos, inserindo dois novos modos em sua descrição. O condicional, que se refere a fatos dependentes de certa condição, e o optativo, que revela a ação como desejada pelo agente. 
Apesar de não desenvolver explicações a respeito dessas noções de maneira aprofundada, é possível notar que o autor indica que existem muitos fatores envolvidos na caracterização semântica apresentada pela noção de modo.

Adotando pressupostos da descrição tradicional, Azeredo (2008: 209-210) apresenta, além da noção de modo verbal, a noção de modalidade. Ao desenvolver as noções de dictum e de modus, apresenta o modus como a variação da entoação da frase para expressar certeza, admiração, dúvida, sendo possível também recorrer-se a verbos que expressam atitudes como 'saber', 'duvidar', 'supor', além de advérbios, como recursos de modalização ou modalidade, conforme os exemplos a seguir:

(4) a.Vocês podem sair. (permissão)

b.Vocês precisam sair. (obrigatoriedade)

(AZEREDO 2008:210)

Ao analisar a categoria tempo, mostra que o enunciador expressa, por meio de mudanças flexionais do verbo, uma série de relações, às vezes sutis, entre o momento em que fala e o momento em que se situam os fatos a que se refere. $\mathrm{O}$ enunciador é, de fato, quem comanda vários tipos de relações que a língua permite exprimir.

a. A porta está fechada.

b. A porta estava fechada

Situação concreta, real, certa.

c. A porta estará fechada

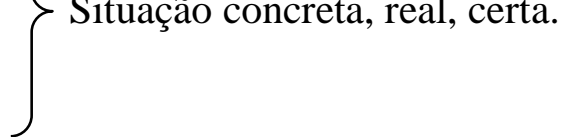

d. É possível que a porta esteja fechada.

e. Acreditávamos que a porta estivesse fechada.

f. Toque a campainha se a porta estiver fechada.
Situação

de possibilidade, dúvida ou suposição

A variação na forma do verbo - 'está/esteja', 'estava/estivesse', 'estará/estiver' para a expressão da atitude do enunciador constitui a categoria gramatical modo. No 
português, o modo e o tempo são expressos por meio dos mesmos morfemas, denominados desinências modo-temporais.

Com base nessas informações, chegamos à conclusão de que a forma como os autores apresentam a noção de modo não satisfaz as possibilidades de realização semântica das sentenças no PB. A investigação a respeito da semântica e da sintaxe das sentenças imperativas no PB requer uma compreensão muito mais detalhada da relação entre o modo verbal e a modalidade. Nesse sentido, passaremos à investigação dessa questão tomando como referência outros estudos que realizam a associação entre modo e modalidade.

\subsubsection{A modalidade e o modo: pressupostos semânticos}

Abordar o desenvolvimento dos conceitos de modalidade e modo na perspectiva da gramática gerativa é uma tarefa que exige a retomada de inúmeros autores e suas contribuições, o que vai além dos objetivos deste trabalho, ainda que seja necessário recorrer a uma definição operacional, diante da sua relevância para a investigação de nosso tema de pesquisa. Por essa razão, vamos apresentar alguns aspectos da caracterização desses conceitos que se mostram relevantes para a discussão das questões que nos propomos investigar, considerando estudos que sistematizam contribuições dos especialistas nesse tema.

Assim, partimos da exposição de Fátima Oliveira, no capítulo 'Modalidade", publicado na obra "Gramática da língua portuguesa", de Mateus et al. (2003), pela abordagem sistemática e objetiva do tema, a ser ampliada com outras contribuições. Oliveira (2003:245) apresenta o conceito de modalidade como a gramaticalização de atitudes e opiniões dos falantes. Afirma que a construção da modalidade nas sentenças pode ocorrer por meio de verbos modais como 'poder' e 'dever', e também por meio de verbos como 'saber', 'crer', 'permitir', 'obrigar', 'precisar de', 'ter de'. Além disso, a modalidade pode ser construída por meio de advérbios como 'possivelmente' ou 'necessariamente', afixos derivacionais como '-vel', que formam adjetivos deverbais como 'lavável', 'concebível', 'solúvel'; além de tempos verbais que podem criar situações alternativas, como é o caso do subjuntivo, do imperfeito, do futuro e do condicional.

Oliveira define a modalidade como a gramaticalização das atitudes do falante. Nesse sentido, a modalidade é vista como uma categoria semântico-formal em que 
intervém, por um lado, uma hierarquia de meios morfológicos, sintáticos, prosódicos e lexicais, e, por outro lado, a atitude do falante perante a validade do conteúdo fixado no enunciado, que é apresentado como coincidente ou não coincidente com a realidade. Há, assim, duas modalidades básicas possíveis em uma sentença: realis e irrealis. A modalidade irrealis é composta por discursos que apresentam um conjunto de situações ou ações que não necessariamente coincidem com a realidade a respeito de que fala o enunciador. Já a modalidade realis representa o que de fato é objeto do discurso do enunciador. Assim, é possível observar que sentenças declarativas sempre apresentam a modalidade realis, em oposição a sentenças contrafactuais condicionais (Se você viesse ontem, teria ganhado um doce) que apresentam claramente a modalidade irrealis.

A respeito dos tipos de modalidade, Oliveira (2003) realiza a divisão, apresentando quatro domínios: modalidades interna ao participante, externa ao participante, deôntica e epistêmica. No que diz respeito à modalidade interna ao participante, insere os itens 'poder' e 'ser capaz de' para possibilidade e 'precisar' e 'necessitar' para necessidade, embora 'necessitar' ocorra em contextos que se assemelham a uma leitura externa ao participante.

De acordo com Oliveira (2003), a modalidade interna refere-se à capacidade ('poder', 'ser capaz de') e necessidade ('precisar', 'necessitar'). É inerente ao participante.

(7) a. A Maria pode sair a qualquer momento.

b. O Rui deve sair amanhã.

(OLIVEIRA 2003:246)

Já a modalidade externa diz respeito às circunstâncias externas (pessoais, regras sociais ou normas) que obrigam ou permitem ao participante envolver-se na situação. Os verbos 'poder' e 'dever' e expressões como 'ter de' são utilizados, quer se trate de permissão ou obrigação direta.

(8) a. O Rui pode sair já.

b. O Rui deve sair já.

c. O Rui tem de sair já.

(OLIVEIRA 2003:247) 
Já a modalidade deôntica está relacionada aos valores de permissão, obrigação e volição. Essa modalidade é condicionada, de um lado, por traços lexicais específicos ligados ao enunciador (+ controle) e, de outro, implica que o enunciatário aceite o valor de verdade do enunciado, para executá-lo.

(9) a.Tu podes/ o Rui pode sair já.

b.Tu deves/ o Rui deve sair já.

c.Tu tens/ o Rui tem de sair já.

(OLIVEIRA 2003:249)

A respeito da modalidade epistêmica, Oliveira (2003) afirma que os verbos modais que exprimem essa modalidade são 'dever' e 'poder'.

(10) a. O Jorge pode ter chegado há minutos.

b. O Jorge deve ter chagado há minutos.

(OLIVEIRA 2003:249)

Outros autores apresentam subdivisões da modalidade epistêmica. São elas as formas certa, plausível (possível epistêmico), contestável e excluído (impossível epistêmico). No entanto, não aprofundaremos as subclassificações dessa modalidade por não serem de interesse deste trabalho.

Segundo Oliveira (2003), os modais apresentam um significado impreciso ou indeterminado, a depender dos contextos em que surgem para determinar o domínio, o raciocínio ou a ação a que se aplicam. Dessa forma, o tipo aspectual dos predicados com os quais se combinam também pode ser relevante, conforme ilustrado a seguir, com dados da autora (p. 250).

(11) a. Ele pode/deve ler o livro até às duas horas. (processo culminado)

b. Ele pode/deve chegar ao cimo do monte. (culminação)

c. Ele pode/deve tocar piano. (processo)

(OLIVEIRA 2003: 250)

A autora ainda apresenta casos em que a leitura deôntica e a leitura epistêmica são possíveis, estando, ao mesmo tempo, acessível a leitura de capacidade e 
probabilidade para 'poder', conforme ilustrado em (12a), em oposição a (12b), extraídos de Oliveira (2003: 250).

(12) a. Ele pode/deve ser simpático.

Estado faseável, adquire características eventivas; leitura deôntica e leitura epistêmica disponíveis

b. Ele pode/deve ser alto. (probabilidade)

Estado não faseável - só a leitura epistêmica disponível.

No exemplo (12a), a leitura deôntica está relacionada com o domínio da ação. Só predicados que envolvam dinamismo, como os eventos e os estados faseáveis (quando adquirem características eventivas), fornecem o contexto apropriado à leitura deôntica. Tal não acontece com (12b), em que se tem o estado não faseável, estando disponível somente a leitura epistêmica.

A respeito da relação entre modalidade e marcadores negativos, Oliveira ressalta que 'poder' pode estar no escopo da negação ou não. A posição da negação interfere na interpretação da modalidade:

a. Ele pode não chegar agora. (leitura epistêmica/ deôntica /[externa algum evento causou])

b. Ele não pode chegar agora. (leitura deôntica/ interna ou externa)

Já o modal 'dever' está fora do escopo da negação, haja vista que é o predicado verbal que é negado, embora sua posição seja tipicamente antes do modal. A realização com o infinitivo composto, porém, permite uma interpretação epistêmica, conforme $(14 c)$ :

(14) a. Ele não deve chegar agora. (leitura deôntica/epistêmica)

b. Ele deve não chegar agora. (leitura deôntica apenas)

c. Ele deve não ter dormido muito bem.

Analisando a expressão da modalidade por uma perspectiva semântica, von Fintel (2006) caracteriza a modalidade como uma categoria linguística relacionada à 
expressão de possibilidades e necessidades, situando uma proposição 'prejacente' em relação a um cenário de possibilidades. É uma categoria expressa por meio de diferentes expressões linguísticas, como afixos, substantivos, adjetivos, advérbios, verbos entre outros. Neste trabalho, o autor apresenta exemplos de diferentes tipos de expressões que têm significado modal no inglês: ${ }^{12}$

a. Sandy must/should/might/may/could be home. Auxiliares modais 'Sandy deveria/deve/pode/poderia estar em casa.'

b. Sandy has tolought to/needs to be home.

Verbos

'Sandy tem de/ precisa estar em casa.'

c. Perhaps, Sandy is home.

Advérbios

'Talvez, Sandy esteja em casa.'

d. There is a slight possibility that Sandy is home.

Nomes

'Há uma leve possibilidade de que Sandy esteja em casa.'

e. It is far from necessary that Sandy is home.

Adjetivo

'Está longe ser necessário que Sandy esteja em casa.'

f. If the light is on, Sandy is home.

Condicionais

'Se a luz está acesa, Sandy está em casa.'

(von FINTEL 2006:1)

Em Von Fintel (2006), observa-se que esses elementos, apesar de terem um conjunto de propriedades gramaticais curiosas, são comumente encontrados como parte do inventário de morfemas gramaticais ou funcionais usados para codificar os significados modais, ainda que associados a idiossincrasias e características gramaticais não produtivas. Ao apresentar os tipos de modalidade, o autor demonstra em exemplos as seguintes classificações: (i) alética, associada à noção de verdade, sendo uma classificação de cunho metafísico; (ii) epistêmica, que diz respeito às noções de possibilidade e necessidade, de uma maneira geral. É uma categoria associada ao conhecimento de mundo; (iii) deôntica, que concerne às noções de necessário, possível, permitido ou obrigatório; (iv) bulética ou bulemaica, associada à representação de desejos e vontades do interlocutor; (v) a modalidade circunstancial ou dinâmica, que diz

\footnotetext{
12 Sabendo dos contrastes translinguísticos no uso de modais, apresentamos uma tradução livre para o português, apenas como um guia para a interpretação dos dados do inglês e dessa forma procederemos nos demais exemplos do capítulo.
} 
respeito a um conjunto de fatores que provocam a realização do conhecimento de mundo e (vi) teleológica, que concerne ao direcionamento a uma meta ou alvo.

Quadro 2.1 - Tipos de modalidade na classificação de von Fintel (2006)

\begin{tabular}{|c|c|c|}
\hline a. It has to be raining. & $\begin{array}{l}\text { 'Tem de estar chovendo.' } \\
\text { (após a observação de } \\
\text { pessoas entrando em um } \\
\text { estabelecimento com } \\
\text { guarda-chuvas) }\end{array}$ & (modalidade epistêmica) \\
\hline $\begin{array}{l}\text { b. Visitors have to } \\
\text { leave by six pm. }\end{array}$ & $\begin{array}{l}\text { 'Os visitantes devem sair } \\
\text { até às seis horas.' }\end{array}$ & (modalidade deôntica) \\
\hline $\begin{array}{l}\text { c. The children have to } \\
\text { go to bed in ten } \\
\text { minutes. }\end{array}$ & $\begin{array}{l}\text { 'As crianças têm de ir para } \\
\text { a cama em dez minutos.' }\end{array}$ & (modalidade bulética) \\
\hline d. I have to sneeze. & 'Eu tenho de espirrar.' & $\begin{array}{l}\text { (modalidade } \\
\text { circunstancial) }\end{array}$ \\
\hline $\begin{array}{l}\text { e. To get home in time, } \\
\text { you have to take a } \\
\text { taxi. }\end{array}$ & $\begin{array}{l}\text { "Para chegar em casa a } \\
\text { tempo, você tem de pegar } \\
\text { um caso.' }\end{array}$ & (modalidade teleológica) \\
\hline
\end{tabular}

Em sua análise, von Fintel (2006) afirma que a modalidade pode ser semanticamente analisada como um instrumento artificial da lógica para compreender um conjunto de mundos possíveis dentro da lógica modal. O princípio desse pensamento remete ao fato de sentenças modais expressarem quantificação sobre mundos possíveis. Isso significa que os diferentes tipos de significados modais correspondem a diferentes opções em relação ao domínio de quantificação. Dessa maneira, a modalidade epistêmica oferece o domínio de quantificação compatível com o que é conhecido, ou seja, com a evidência disponível no mundo de avaliação. A modalidade bulética quantifica sobre mundos, levando em consideração os desejos do interlocutor. Já a modalidade deôntica, oferece o domínio de quantificação sobre mundos que satisfazem leis ou princípios. Em resumo, a análise de sentenças com expressões modais deve ser interpretada com base em três fatores: (i) a força 
quantificacional (possibilidade, necessidade e uma diversa gama de matizes), (ii) um conjunto de mundos acessíveis (base modal) e (iii) uma ordenação desses mundos.

\subsection{Modo e Modalidade na estrutura oracional}

\subsubsection{Noções gerais}

O uso do termo modalidade traz a noção de conteúdo semântico, enquanto o termo modo gramatical contém uma possível manifestação morfológica da modalidade. Modo verbal compreende flexões como indicativo, subjuntivo e infinitivo, e correspondem a contextos sintáticos em que a modalidade pode se manifestar. Ainda sobre modo, existem outras formas de expressão de atitudes modais e conceitos, como verbos modais, adjetivos ou nomes.

Apresentaremos aqui as noções iniciais de modalidade propostas em Kratzer (2012). Seguindo a tradição, Kratzer assume que a modalidade está relacionada à necessidade e à possibilidade. Nesse sentido, segundo a autora, palavras modais possuem comumente leituras ambíguas. Os exemplos a seguir demonstram a ambiguidade de leituras associadas ao modal must, conforme o quadro abaixo.

Quadro 2.2 - Tipos de leitura modalizada em Kratzer (1991)

\begin{tabular}{|c|c|c|}
\hline $\begin{array}{l}\text { a. Jockl must have } \\
\text { been the murderer. }\end{array}$ & $\begin{array}{l}\text { 'Jockl deve ter sido o } \\
\text { assassino.' }\end{array}$ & $\begin{array}{l}\text { (leitura epistêmica - in view } \\
\text { of the available evidence, } \\
\text { Jockl must have been the } \\
\text { murderer) }\end{array}$ \\
\hline b. Jockl must go to jail. & $\begin{array}{l}\text { 'Jockl deve ir para a } \\
\text { prisão.' }\end{array}$ & $\begin{array}{l}\text { (leitura deôntica - in view } \\
\text { of what the law provides, } \\
\text { Jockl } \\
\text { must go to jail) }\end{array}$ \\
\hline c. Jockl must sneeze. & 'Jockl deve espirrar.' & $\begin{array}{l}\text { (leitura circunstancial - in } \\
\text { view of the present state of } \\
\text { his nose, Jockl must } \\
\text { sneeze) }\end{array}$ \\
\hline
\end{tabular}

(KRATZER 1991:640) 
Kratzer (1991) apresenta as sentenças acompanhadas de paráfrase para o entendimento das diferentes variedades de modalidades. O modal na sentença 'a' denota necessariamente a disponibilidade de evidência, em ' $b$ ', necessariamente a existência de lei e em 'c' a possibilidade relativamente às circunstâncias.

Kratzer (1991), afirma que um verbo modal pode expressar uma relação entre o que é conhecido e uma proposição. Dessa maneira, o núcleo semântico da modalidade é construído com base nessa relação expressa pelo verbo. Assim, uma sentença como 'eles chegaram' pode ser parafraseada como 'no sentido do que é conhecido, eles chegaram.'

Para desenvolver a discussão a respeito das palavras modais, Kratzer (1991: 640-642) recorre aos conceitos de proposição, valor de verdade, consequência lógica, consistência, compatibilidade lógica e fundo conversacional, sendo esse último conceito essencial para o desenvolvimento da análise da modalidade presente nas sentenças imperativas.

As proposições são apresentadas pela autora como uma característica comum da elocução de sentenças. Toda elocução de sentenças expressa proposições. Em uma semântica de mundos possíveis, uma proposição é identificada com um conjunto de mundos possíveis, em que é verdadeira. Supondo que seja dado um conjunto $\mathrm{M}$ de mundos possíveis, uma proposição é então verdadeira em um subconjunto de $\mathrm{M}$.

Para definir o valor de verdade de uma proposição, Kratzer (1991) afirma que uma proposição $\mathrm{p}$ é verdadeira em um mundo $\mathrm{m}$ em que $\mathrm{m} \in \mathrm{M}$ se, e somente se, $\mathrm{m} \in \mathrm{p}$, caso contrário, p é falsa em $\mathrm{m}$. O conceito de consequência lógica pode ser definido como uma proposição $\mathrm{p}$ que segue um conjunto de proposições $\mathrm{A}$ se e somente se $\mathrm{p}$ é verdadeira em todos os mundos $\mathrm{M}$ no qual todas as proposições A são verdadeiras. Ao definir a consistência lógica, a autora propõe que um conjunto de proposições A é consistente se, e somente se, existe um mundo $\mathrm{M}$ em que todas as proposições de $\mathrm{A}$ sejam verdadeiras. A definição de compatibilidade lógica adotada diz que uma proposição p é compatível com um conjunto de proposições A se, e somente se, A U $\{\mathrm{p}\}$ é consistente.

Por fim, o fundo conversacional, nos termos de Kratzer (1991), é um dos conceitos mais importantes aplicados à análise da modalidade nas sentenças das línguas naturais. Um fundo conversacional é o conjunto de regras que as leis fornecem ou o conjunto de saberes que temos a respeito do mundo. Levando em conta o conjunto de regras que a lei prevê, o que é previsto pode ser diferente de um mundo possível para outro. O que a lei prevê para um mundo específico é um conjunto de proposições. Essas 
proposições podem ser diferentes de um mundo para outro. Nesse contexto, a denotação do que sabemos (conhecimento de mundo) é o que a lei prevê . O que a lei fornece é diferente de um para outro mundo possível . E o que o lei fornece em um mundo particular é um conjunto de proposições.

Da mesma forma, o conjunto de conhecimentos que caracteriza o que sabemos é diferente de um mundo para outro. O que sabemos em um mundo particular é um conjunto de proposições. A denotação do que a lei estabelece será, então, a função que atribui a cada mundo possível o conjunto de proposições $p$, tal que a lei fornece $p$ nesse mundo. E a denotação do que sabemos é a função que atribui para todo mundo possível o conjunto de proposições que sabemos nesse mundo. Assim, considerando a sentença em (16), temos o conjunto de modalizações possíveis em (17).

(16) They must have arrived.

'Eles devem ter chegado.'

Quadro 2.3 - Conjunto de modalizações em Isac (2015)

\begin{tabular}{|l|l|l|}
\hline Modal relacional & Restrição modal & Escopo modal \\
\hline Must in view of & What is known & They have arrived \\
\hline
\end{tabular}

(ISAC 2015:37)

Isac (2015), em referência ao trabalho de Kratzer (1991), afirma que algumas sentenças modais expressam restrições modais abertamente. Outras já não o fazem abertamente. Inicialmente, devemos considerar que a restrição modal é sempre providenciada pelo contexto. No sentido de compreender as restrições dadas pelo contexto, consideremos os exemplos de Kratzer, presentes em Isac (2015) a seguir.

(18) a. All Maori children must learn the names of their ancestors.

'Todas as crianças maori devem aprender os nomes de seus antepassados.'

b.The ancestors of the Maoris must have arrived from Tahiti.

'Os antepassados dos Maoris devem ter chegado do Tahiti.'

c.If you must sneeze, at least use your handkerchief.

'Se você deve espirrar, pelo menos use seu lenço.' 
d. When Kahukura-nui died, the people of Kahungunu said: Rakaipaka must be our chief.

'Quando Kahukura-nui morreu, as pessoas de Kahungunu disseram: Rakaipaka precisa ser o nosso chefe.'

(ISAC, 2015:37)

De acordo com Isac, a sentença (18a) invoca um conjunto de normas ou deveres e, por esse motivo, é considerada deôntica. O must em (18b) é relacionado a uma parte do conhecimento ou evidência, o que o torna epistêmico. O tipo de must em (26c) é chamado disposicional, pois leva em conta a disposição que as pessoas têm quando não podem ajudar em uma situação de um espirro, conforme o exemplo. O exemplo (26d) é relacionado às preferências ou desejos (bulético). Para Isac, cada modal corresponde a uma única entrada lexical. No entanto, sua força quantificacional é diferente (existencial ou universal) - conforme observa Hacquard (2009), citada em Costa (2016: 105-106), que relaciona modais do tipo 'dever' e 'poder' em termos de acarretamento, assim como o quantificador universal e o existencial o são. ${ }^{13}$ Contudo, nos exemplos anteriores vimos que os modais expressam uma gama variada de modalidades. A pluralidade de interpretações é possível pelo fato de que quantificadores modais são determinados pelo léxico.

O que a restrição modal nos diz é que ao valorarmos um modal, um subconjunto de palavras é disponibilizado. O domínio da valoração (o conjunto de palavras possíveis) é restringido pelo contexto de acordo com o fundo conversacional. Essa restrição ativa um papel análogo ao NP, restringindo o domínio de quantificação. É assim, por exemplo, que podemos ver a restrição da palavra 'todo' em uma frase como 'Todo homem fuma'.

Isac ainda afirma que o fundo conversacional é definido como uma função que atribui um conjunto de proposições a mundos possíveis. Um fundo conversacional epistêmico, definido como o conjunto de conhecimentos 'do que é conhecido', por exemplo, pode definir a função de uma palavra 'p' ao conjunto de possibilidades que são conhecidas em ' $p$ '. Esse fundo conversacional epistêmico restringe o domínio de quantificação do modal ao conjunto de palavras compatíveis com o que é sabido. Da mesma maneira, um fundo conversacional deôntico restringe o domínio de palavras possíveis que são compatíveis com regras, leis e regulações. Em (19a) a base modal é realizada por todos os mundos em que a lei é obedecida e a sentença modal diz que em

${ }^{13}$ A relação se exemplifica como a seguir: João deve sair $\rightarrow$ [acarreta que] João pode sair; Todos os alunos saíram $\rightarrow$ [acarreta que] Algum aluno saiu. 
todos os mundos dessa base modal (i.e., em todos os mundos que a lei é obedecida), (19a) é considerada verdadeira e, por isso, Jane não deve roubar.

(19) a. Jane must not steal.

'Jane não deve roubar.'

b. In view of what the law says, Jane must not steal.

'Em vista do que a lei diz, Jane não deve roubar.'

(ISAC 2015: 38)

Essa restrição determinada pelo contexto provê a base modal para a interpretação do modal. Isac (2015) afirma, contudo, que a base modal não é o único tipo de restrição modal provida pelo contexto. Um modal é restringido por um segundo fundo conversacional - a fonte da ordenação, que ordena os mundos em uma base modal de acordo com um ranking contextual. Fontes de ordenação capturam a observação de que o entendimento de uma sentença modalizada implica o uso de estados de coisas idealizados, descrevendo o mundo como ele deveria ser (de acordo com a lei, de acordo com o curso normal dos eventos, de acordo com o que é desejável, etc.). Uma fonte de ordenação - um conjunto de proposições que descrevem o ideal - ordena proposições em uma base modal de acordo com o grau que atingem na realização do que foi descrito pela fonte de ordem em si mesma.

Para esses casos, a base modal do mesmo tipo de 'b' não é suficiente. A base modal de (19b) contém todos os mundos em que a lei é obedecida e isso significa o que é relevante para a interpretação de 'a' são os mundos em que a lei é desobedecida. Tal situação distingue-se de Jane must go to jail ('Jane tem de ir para a cadeia'), em que a fonte de ordenação que garante a verdade de (19a) é insuficiente, pois inclui todos os mundos em que a lei é obedecida, mas não prevê a restrição correta. Diante disso, faz-se necessário um segundo fundo conversacional, conforme citado anteriormente, que ordena os mundos em uma base modal de acordo com um conjunto ideal de um corpo de leis. O matiz deôntico do modal resulta dessa fonte de ordenação, o que lhe confere um caráter circunstancial. Assim, conforme resume Isac (2015: 39), em uma síntese do trabalho de Kratzer (1991), "os melhores mundos em consonância com essa fonte de ordenação serão aqueles em que nenhuma lei é desobedecida, o próximo mundo melhor não terá nenhuma lei desobedecida (e. g. Jane roubou), mas os outros obedeceram (Jane vai para a cadeia, etc. Considerando que uma base modal circunstancial retorna ao 
conjunto de mundos, nos quais Jane roubou, os melhores mundos nesse conjunto serão aqueles em que existe um ladrão, Jane, mas em que ela vai para a cadeia" (ISAC 2015; $39)^{14}$. Assim, Isac propõe que a base modal (circunstancial) conterá o fato de que Jane roubou ou quebrou a lei de alguma forma. A fonte de ordenação pode ser definida como um conjunto de proposições L, que descreve um corpo de leis (como a proposição de que não há ladrões, que não há assassinos e que assassinos vão para a cadeia). Esse conjunto de proposições irá constituir uma ordenação na base modal circunstancial. Essa ordenação diz que um mundo $\mathrm{x}$ é mais ideal que um mundo y se a maioria das proposições no conjunto $\mathrm{L}$ contenham mais $\mathrm{x}$ do que $\mathrm{y}$. Assim, o melhor mundo de acordo com a fonte de ordenação será aquele em que nenhuma lei é quebrada, o segundo mundo melhor será aquele em que terá apenas uma lei quebrada, mas outras obedecidas. Dado que a base modal circunstancial retorna ao conjunto de mundos em que a ação é realizada, os melhores mundos no conjunto serão aqueles em que há uma ladra (no contexto de 18a, Jane), mas ela irá para a cadeia.

Isac (2015) ainda considera que uma base deôntica modal é restrita por dois fundos conversacionais: primeiro pela base modal circunstancial $\mathrm{f}(\mathrm{w})$, que retorna um conjunto de mundos em que certos fatos em w estão contidos (Jane roubou um carro); segundo, um conjunto de mundos dados por $\mathrm{f}(\mathrm{w})$ que são classificados por uma fonte de ordenação $\mathrm{g}(\mathrm{w})$, de acordo com um ideal provido pela lei.

Diante das considerações sobre a modalidade, conforme sistematizadas nesta seção, passamos a discutir o estatuto dessa categoria em sentenças imperativas. Essa questão mostra-se relevante para a presente análise, uma vez que existe uma divergência na literatura em relação ao estatuto das formas do imperativo (particularmente pelo contraste entre imperativo verdadeiro e supletivo) como realização da categoria Modo, considerada uma realização gramatical/ morfossintática da Modalidade nesse tipo de sentença, conforme passamos a apresentar, seguindo exposição de Isac (2015), cuja proposta será (parcialmente) adotada neste trabalho.

\footnotetext{
14 "Thus, the best worlds according to this ordering source will be those in which no law is broken, the next best world will have one law broken (e. g. Jane stole), but the others obeyed (e.g. Jane goes to jail), etc. Given that the circumstantial modal base returns a set of worlds in which Jane stole, the best worlds in this set will be those in which these is a thief, Jane, but where she goes to jail." [tradução deste autor]
} 
2.3.2 O imperativo não é um modal: a argumentação de Portner (2007)

De acordo com Isac (2015), Portner (2007) argumenta que as formas do imperativo podem ser interpretadas como uma grande subvariedade de modais não dinâmicos, admitindo leituras deônticas, buléticas e teleológicas. Nessa discussão, o autor assume a divisão tripartite dos modais, que distingue modais epistêmicos, deônticos e dinâmicos, referida anteriormente (ver seção 3.1), embora, defenda que o tipo deôntico seja substituído por uma classe por ele chamada de priority modals (modais prioritários), que incluem leituras deônticas, buléticas e teleológicas. Dessa forma, defende que a interpretação das sentenças imperativas está diretamente associada à interpretação dos modais prioritários. $\mathrm{O}$ autor afirma que as sentenças imperativas, assim como declarativas, utilizam fundo conversacional como contexto e uma fonte de ordenação. Essa fonte de ordenação pode estabelecer leis ou regulamentos (no caso de modais prioritários deônticos), desejos (no caso de modais prioritários buléticos), ou metas (no caso de modais prioritários teleológicos) (ISAC 2015: 41) ${ }^{15}$. Em particular, a fonte de ordenação é dada por uma to-do list (lista de tarefas), que serve de guia em relação às ações que o alocutário deve se comprometer a cumprir.

Portner parte da argumentação de que imperativos têm uma dimensão modal, dado que eles apresentam uma proposição como um estado de coisas possível e desejável. Nesse sentido, considerando sua expressão morfossintática em línguas românicas por meio da forma verdadeira e supletiva (esta última associada ao subjuntiva), imperativos podem ser tratados como ocorrências da categoria Modo $(\mathrm{Mood})$, entendidas como manifestações morfológicas da modalidade.

Contudo, a opinião de Portner (2007) é que imperativos não devem ser igualados a modais prioritários, conforme é argumentado na literatura, com base no fato de que eles compartilham as interpretações citadas anteriormente. Para o autor, imperativos e modais se distinguem em relação a duas propriedades básicas, a 'denotação' (denotation) e o 'sujeito' (subject), a seguir descritas.

\footnotetext{
${ }^{15}$ The parallelism between root modals and imperatives extends to the ordering source, as well. The ordering source of root modals orders the propositions in the modal base according to some standart: either laws or regulation (in the case of deontic priority modals), wishes/ desires (in the case of bouletic priority modals), or some goals (in the case of teleological priority modals).
} 
A respeito da denotação (denotation), Portner (2007) utiliza os dados em (20), observando que sentenças modais, como (20a), podem ser avaliadas como verdadeiras ou falsas, enquanto imperativos, como (20b), não podem.

(20) a. Noah should sit down right now (given that he's ordered to do so).

'Noah deveria sentar-se agora (dado que ele é obrigado a fazê-lo) '

b. Sit down right now!

'Sente-se agora!'

(PORTNER 2007:359)

Para o autor, (20a) é verdadeira se é possível constatar que decorre das proposições na base modal que Noah se senta e falsa se a regra falha no que diz respeito a Noah se sentar. Diferentemente, não há como considerar (20b) verdadeira ou falsa.

Já em (21a-b), o modal de prioridade pode se referir a um sujeito de primeira, segunda ou terceira pessoa, enquanto o sujeito de imperativo se restringe à segunda pessoa.

(21) a. \#Sam must go to confession, but he's not going to.

b. \#You must go to confession, but you're not going to.

c. \#I must go to confession, but I'm not going to.

(22) \#Go to confession! You're not going to go to confession.

(PORTNER 2007:364)

Tais fatores são considerados cruciais pelo autor na caracterização de uma sentença como modal ou não, o que o leva a concluir que imperativos não seguem o padrão característico de sentenças modais com respeito a essas propriedades.

A seguir, veremos a contra-argumentação de Isac (2015) quanto a essa conclusão.

2.3.3 Fatores relevantes para comprovação da modalidade em sentenças imperativas

Com o objetivo de demonstrar a presença de interpretação modal em imperativos, Isac (2015) argumenta, contra Portner (2007), que os imperativos não são modais no sentido em que os modais de prioridade o são. Nesse sentido, propõe que a modalidade dos imperativos possui diferentes características se comparada aos modais de prioridade. 
Isac (2015) trabalha com as duas características que Portner (2007) afirma serem problemáticas na identificação de imperativos como modais, citadas anteriormente - a saber a denotação, em que se constata ausência de valor de verdade, e o sujeito, em que se constata a orientação fixa para o sujeito de $2^{\mathrm{a}}$ pessoa). Sua argumentação se apoia na ideia de que "these properties are relevant for distinguishing not only between priority modals and imperatives, but also between two larger classes of verbal forms, that include priority modals and imperatives, respectively" (ISAC 2015: 42). ${ }^{16}$ De acordo com Isac (2015), essa classe maior, formada pelos imperativos e por outras formas verbais que são indiscutivelmente modais, contrasta com os modais prioritários. Nesse sentido, demonstrar que os modais prioritários são essencialmente modais não significa ausência de modalidade nos imperativos, mas simplesmente que a classe a que pertencem os imperativos manifesta a modalidade de uma maneira diferente. Para argumentar, a autora retoma as características citadas por Portner (2007).

\subsubsection{Ausência de valor de verdade}

A respeito da primeira característica problemática apontada por Portner (2007), Isac (2015) afirma que, como no caso dos imperativos, a ausência de valor de verdade pode ser constatada em epistêmicos verdadeiros e deônticos verdadeiros. Assim, em (35), em uma situação em que a evidência está disponível (apenas) para o falante (orientação para o falante), não há como avaliar o valor de verdade (a não ser pelo falante).

(23) Superman must be jealous of Lois.

'O Super-homem deve ter inveja de Lois.'

(ISAC 2015:44)

Outros diagnósticos, mostrados por Papafragou (2006), e outros autores, conforme Isac (2015: 44), confirmam o argumento, como a impossibilidade de encaixar modais epistêmicos em estruturas factivas, ou de contestar ou endossar seu conteúdo, como em (24a-b), também observada em imperativos, como em (25):

(24) a.? It's surprising that Superman must be jealous of Lois.

'É supreendente que o Super homem deve ter inveja de Lois. '

\footnotetext{
16 “(...) essas propriedades são relevantes para distinguir não apenas imperativos dos modos prioritários, mas também duas grandes classes de formas verbais que incluem modais prioritários e imperativos, respectivamente. [Tradução deste autor]
} 
b. A. Superman must be jealous of Lois.

B.? I don't believe it/? That's not true/? I agree

'? Eu não acredito nisso/? Não é verdade. /? Eu concordo.'

(ISAC 2015:44)

(25) a. Leave now!

'Saia agora!'

b.? It is surprising that you must leave now.

'? É surpreendente que você tem de sair agora.'

c.? I don't believe it.

'? Não acredito nisso.'

d.? That's not true.

'? Não é verdade.'

e.? I agree.

'? Eu concordo.'

(ISAC 2015:44)

\subsubsection{Orientação ao sujeito}

Em relação ao sujeito, em que, na problematização de Portner (2007), a orientação fixa para o interlocutor é atribuída ao imperativo, em oposição aos modais prioritários, Isac (2015) observa que alguns deônticos expressam uma obrigação ou permissão que é colocada no destinatário. Seguindo Hacquard (2006), Isac (2015) designa esse subtipo de verdadeiros deônticos. No entanto, destaca que nem todos os deônticos apresentam essa propriedade, pois existem também aqueles em que a orientação é para o sujeito. Assim, a autora propõe que sejam divididos em duas categorias: verdadeiros deônticos (em que a ordem é dirigida ao destinatário) e deônticos orientados ao sujeito (em que a ordem é dirigida ao sujeito).

Para ilustrar, é possível demonstrar que uma das possíveis interpretações do deôntico must é a de (26a), pois é a obrigação que vem de certas normas ou regras e da responsabilidade individual do sujeito de executar o comando (orientação para o sujeito). A outra interpretação está parafraseada em (26b), em que o modal é interpretado como uma obrigação dirigida ao destinatário:

(26) Kitty must/has to brush her teeth. 
'Kitty tem de escovar os dentes.'

a. According to some set of rules, Kitty must brush her teeth.

b. (Talking to the babysitter) I (i.e. the speaker) am putting an obligation on you (i.e. the adressee) to see to it that Kitty brush her teeth. ${ }^{17}$

(ISAC 2015:45)

O mesmo se aplica aos modais epistêmicos, que também se subdividem em dois tipos: um epistêmico que expressa um estado do falante, e outro que expressa um estado epistêmico do sujeito. Dessa forma, é possível identificar o subtipo que denota o estado do falante, com a propriedade de ser ancorado a um participante do ato discursivo, exatamente como os imperativos.

(27) Pour aller au zoo, Jane a dû prendre le train. (French)

'Para ir ao zoológico, Jane teve de pegar o trem.'

(ISAC 2015:45)

Isac (2015) observa que o exemplo (27) é ambíguo, admitindo a interpretação epistêmica orientada ao sujeito, em que se leva em conta o conhecimento de Jane das circunstâncias relevantes - o conhecimento em relação à distância do zoológico, a disponibilidade de outros meios de transporte, do tempo quando ela foi ao zoo etc -, e a interpretação orientada ao falante, em que é levada em conta a evidência disponível ao falante. A ida de Jane ao zoo é compatível com essa evidência. O subtipo orientado para o falante será considerado verdadeiro epistêmico e, com o imperativo, compartilha a propriedade de ser orientado para um participante do evento. O outro tipo, constituído pelos modais não verdadeiros, correspondem aos modais prioritários raízes, e não aos modais não raízes.

Assim como os outros predicados que se comportam como os imperativos são orientados ao destinatário, existem predicados que se alinham com raízes modais prioritárias no sentido de que são orientadas ao sujeito, em vez de serem direcionados ao destinatário. Assim, um modal dinâmico como can (28) pode se referir livremente à habilidade de um sujeito de terceira pessoa do plural ou uma segunda pessoa, por exemplo.

\footnotetext{
${ }^{17}$ De acordo com um certo conjunto de regras, Kitty tem de escovar os dentes.

b. (Falando à babysitter) (i.e. o falante) Estou colocando minha ordem em você (i. e o destinatário) para garantir que Kitty escove os dentes. [tradução deste autor]
} 
(28) a. They can eat twenty apples in an hour (ability, 3rd person plural subject)

b. I can eat twenty apples in an hour. (ability, 1st person subject)

(ISAC 2015:44)

Com o objetivo de comprovar as diferenças entre os dois tipos de classe de elementos modais (uma que contém os imperativos e que contrasta com os modais prioritários), Isac (2015) apresenta ainda duas outras propriedades: acarretamentos de atualização e orientação temporal.

\subsubsection{Acarretamentos de realização no mundo real (Actuality entailments)}

Isac (2015) mostra que modais prioritários e modais dinâmicos permitem o acarretamento de que o evento descrito pelo verbo lexical a que se ligam ocorreu no mundo real, o que não ocorre com imperativos, verdadeiros epistêmicos e verdadeiros deônticos. A autora contrasta dados para demonstrar que o modal prioritário no perfectivo traz um acarretamento de realização no mundo real para o evento descrito no complemento, e não somente em mundos possíveis.

(29) a. Pour aller au zoo, Jane devait prendre le train.

For goINF to zoo Jane had take.INF the train

'To go to the zoo, Jane had to take the train.' 18

b. Pour aller au zoo, Jane a dû prendre le train.

For go.INF to zoo, Jane has had take.INF the train.

'To go to the zoo, Jane had to take de train.' (actualized necessity) ${ }^{19}$

(ISAC 2015:48)

Nota-se que a codificação da interpretação de acarretamento confirmado pela realização no mundo real pelo aspecto perfectivo (gramatical) não está disponível em todas as línguas (comparem-se os dados do francês em (29a) e (29b), e também a respectiva tradução em português nas notas 6 e 7, com suas respectivas traduções em inglês, em que não há diferença gramatical na codificação do aspecto). Esse contraste é referido por Bhatt (1999), citado por Isac (2015:49). Embora os acarretamentos de atualização de realidade dos modais prioritários e dinâmicos não sejam codificados no

\footnotetext{
18 "Para ir ao zoo, Jane tinha de pegar o trem."

19 "Para ir ao zoo, Jane teve de pegar o trem." (necessidade consistente com a realidade)
} 
aspecto perfectivo em inglês, podem ser realizados também por meio de advérbios temporais.

Isac (2015) demonstra então que, em contraste com modais prioritários e dinâmicos, verdadeiros epistêmicos, verdadeiros deônticos e imperativos não estão sujeitos ao acarretamento de realização no mundo real.

Considerando uma sentença como 'Close the door', nota-se que, de nenhuma forma, existe a implicação de que a porta foi fechada ou que será fechada. A autora acrescenta que, mesmo em línguas em que existem imperativos perfectivos, como o polonês, o acarretamento de realização no mundo real não se sustenta, embora exista um tipo de acarretamento teleológico. Nessa língua, "the perfective imperative is used when the addressee is to carry the action to completion" (p. 49). ${ }^{20}$

A autora conclui mostrando que epistêmicos verdadeiros e deônticos verdadeiros, como o imperativo, não impõem acarretamento de realização no mundo real, o que confirma a hipótese de que o imperativo possui propriedades compartilhadas com verdadeiros modais. Conforme destacado anteriormente, Isac (2015) recorre a essa identificação para questionar o argumento de Portner (2009) quanto à ausência da categoria modo na estrutura de orações imperativas, com base na ausência de alinhamento dessas formas verbais com modais de prioridade no que se refere a outras propriedades.

\subsubsection{Orientação temporal}

Isac (2015) traz ainda uma diferença entre modais prioritários e modais dinâmicos, por um lado, e imperativos, verdadeiros deônticos e verdadeiros epistêmicos, por outro, para confirmar sua proposta de que imperativos não são desprovidos da categoria modo em sua projeção sintática. Trata-se da perspectiva de orientação temporal. Nota-se que modais prioritários e dinâmicos são compatíveis com o tempo passado, diferentemente de imperativos, epistêmicos verdadeiros e deônticos verdadeiros, que não podem ser interpretados no passado.

A incompatibilidade entre o passado e o imperativo pode ser explicada em termos da noção de anomalia semântica, uma vez que direcionar uma obrigação ao destinatário para realizar uma ação no passado não tem sentido. Isac (2015) refere-se ao estudo de Zanuttini

\footnotetext{
20 “ (...) o imperativo perfectivo é usado quando o destinatário deve levar uma ação ao término. " [Tradução deste autor]
} 
(1991), em que é demonstrado que a incompatibilidade entre imperativo e tempo não se restringe ao tempo passado, assumindo-se que a avaliação da interpretação temporal do imperativo é sempre dependente do momento de fala. Da mesma forma, o tempo de realização dos verdadeiros epistêmicos e verdadeiros deônticos é o presente.

Tomando como referência dados do inglês citados por Hacquard (2006), a autora demonstra que mesmo em sentenças com o modal might (passado) que denota uma possibilidade acerca de um tempo passado, a avaliação é feita em relação ao momento de fala: "it is possible, as far as I (the speaker) know (right now), that (at some past time) they won the game. ${ }^{21}$ (HACQUARD, 2006:51)

(30) They might (already) have won the game.

Traz-se à tona um choque entre o tempo de realização do comando direcionado ao destinatário e o tempo de realização da ação proposta, no caso, no passado, o que não se observa em relação aos epistêmicos verdadeiros, que podem ser avaliados no tempo presente, em relação a uma denotação referente a um tempo passado.

Assim, Isac (2015) apresenta quatro propriedades para distinguir dois grupos de elementos modais: ancoramento do sujeito em um dos participantes do evento discursivo, denotação, acarretamentos de realização no mundo real e orientação temporal. Com essa sistematização, a autora demonstra que a distinção não se resume aos modais prioritários e imperativos, mas entre modalidades raízes (modais prioritários e dinâmicos), por um lado, e portadores de modalidade não raiz, por outro lado. Essas informações são apresentadas no quadro a seguir, extraído de Isac (2015: 53):

21 “(...) é possível, até onde eu (o falante) sei (agora), que (em algum tempo passado) eles ganharam o jogo.’[tradução deste autor] 
Quadro 2.4 - Tipos de elementos modais, conforme Isac (2015)

\begin{tabular}{|c|c|c|c|c|}
\hline $\begin{array}{l}\text { Type/ } \\
\text { Tipo }\end{array}$ & $\begin{array}{l}\text { Anchor/ } \\
\text { Ancoramento }\end{array}$ & $\begin{array}{l}\text { Truth value/ } \\
\text { Valor de } \\
\text { verdade }\end{array}$ & $\begin{array}{l}\text { Actuality } \\
\text { entailment/ } \\
\text { Acarretamento } \\
\text { no mundo real }\end{array}$ & $\begin{array}{l}\text { Temporal } \\
\text { orientation/ } \\
\text { Orientação } \\
\text { Temporal }\end{array}$ \\
\hline $\begin{array}{l}\text { Imperative/ } \\
\text { Imperativo }\end{array}$ & $\begin{array}{l}\text { Participant to } \\
\text { Speech Event/ } \\
\text { Participante no } \\
\text { Evento de fala }\end{array}$ & - & No/ não & $\begin{array}{l}\text { Speech time/ } \\
\text { Momento de } \\
\text { Fala }\end{array}$ \\
\hline $\begin{array}{l}\text { "True" } \\
\text { Deontic/ } \\
\text { Deôntico } \\
\text { Verdadeiro }\end{array}$ & $\begin{array}{l}\text { Participant to } \\
\text { Speech Event/ } \\
\text { Participante no } \\
\text { Evento de fala }\end{array}$ & - & No/ não & $\begin{array}{l}\text { Speech time/ } \\
\text { Momento de } \\
\text { Fala }\end{array}$ \\
\hline $\begin{array}{l}\text { "True" } \\
\text { epistemic/ } \\
\text { Epistêmico } \\
\text { Verdadeiro }\end{array}$ & $\begin{array}{l}\text { Participant to } \\
\text { Speech Event/ } \\
\text { Participante no } \\
\text { Evento de fala }\end{array}$ & - & No/ não & $\begin{array}{l}\text { Speech time/ } \\
\text { Momento de } \\
\text { Fala }\end{array}$ \\
\hline $\begin{array}{l}\text { Priority modal/ } \\
\text { Modal } \\
\text { Prioritário }\end{array}$ & $\begin{array}{l}\text { Subject/ } \\
\text { Sujeito }\end{array}$ & + & Yes/ Sim & $\begin{array}{l}\text { Time provided by } \\
\text { Tense/ } \\
\text { Tempo } \\
\text { fornecido pelo } \\
\text { tempo }\end{array}$ \\
\hline $\begin{array}{l}\text { Dinamic modal/ } \\
\text { Modal } \\
\text { Dinâmico }\end{array}$ & $\begin{array}{l}\text { Subject/ } \\
\text { Sujeito }\end{array}$ & + & Yes/ Sim & $\begin{array}{l}\text { Time provided by } \\
\text { Tense/ } \\
\text { Tempo } \\
\text { fornecido pelo } \\
\text { tempo }\end{array}$ \\
\hline
\end{tabular}

\subsubsection{Posicionamento da categoria Modo na estrutura de sentenças imperativas}

Conforme observa Isac (2015), uma consequência de fazer a distinção entre os dois tipos de modais é que não é possível manter a proposta de Kratzer (1991), segundo a qual existe apenas uma entrada lexical para o modal, sendo as diferentes interpretações determinadas no contexto (definido como fundo conversacional, em 
função da base modal e de uma fonte de ordenação). Assim, uma forma de reter (parcialmente) a ideia de Kratzer é assumir que cada classe corresponde a uma entrada lexical, que, por sua vez, ocupa uma posição sintática distinta na estrutura oracional, o que não exclui o fundo conversacional, que deve prover os mundos possíveis e a fonte ordenação em cada caso. Nesse sentido, seguindo (parcialmente) Kratzer (1991), assumimos que o modal é inserido como um item em uma dada posição, sendo as possibilidades de interpretação determinadas pelo fundo conversacional, que inclui a base modal e a fonte de ordenação.

Diante da identificação das duas classes de elementos modais, com a inclusão dos imperativos, Isac (2015) propõe realizar os dois tipos de modais em dois posicionamentos distintos na estrutura sintática: uma posição mais baixa para modais prioritários e dinâmicos e uma posição mais alta para verdadeiros epistêmicos, deônticos e também imperativos. ${ }^{22}$

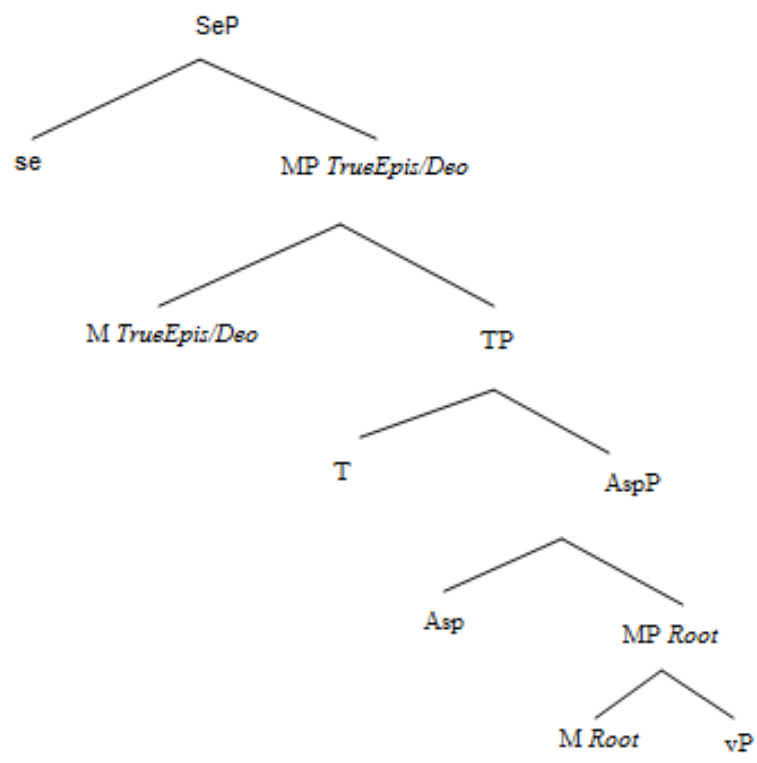

(ISAC 2015:59)

Isac (2015) observa que a estrutura em (31) comporta uma análise como a de Hacquard (2009), que utiliza a posição relativa do nódulo de Aspecto em relação à

\footnotetext{
${ }^{22}$ Isac parte da análise de Hacquard (2006), que não trata de imperativos. No entanto, a autora assume que a análise de Hacquard pode ser estendida aos imperativos em razão do compartilhamento das propriedades com os verdadeiros deônticos e verdadeiros epistêmicos, conforme demonstrado na seção anterior.
} 
projeção que hospeda o modal de raiz para dar conta dos contrastes de acarretamento de realização no mundo real. Assim, se AspP é projetado acima do modal de raiz, o acarretamento de realização no mundo real se sustenta, pois a variável de 'mundo', introduzida, por hipótese, pelo núcleo Asp, poderá ser ligada por um elemento default ou por um outro modal realizado acima dessa projeção, que confere a referida interpretação; diferentemente, se AspP for dominado pela posição que hospeda modais epistêmicos verdadeiros e deônticos verdadeiros, a variável de mundo de Asp será ligada por esse modal, e a leitura de acarretamento de realização no mundo real não se manifesta. As diferenças translinguísticas no ordenamento da categoria de aspecto e do modal de raiz são tratadas em termos das exigências de SpellOut.

Citando a análise de Bhatt (1999), que distingue as interpretações perfectiva e não-perfectiva em termos da distinção mais geral entre genéricos e não-genéricos, Isac $(2015 ; 56)$ propõe que o contraste nos acarretamentos de realização em um mundo real seja analisado em termos dessa noção, tendo em vista os estudos que demonstram que a contribuição semântica do aspecto imperfectivo nas línguas em geral é a genericidade, o que não ocorre com o perfectivo. Cabe ainda destacar que, além do aspecto imperfectivo, o operador genérico pode ter outras fontes, como verbos modais e o tempo presente.

Isac (2015) acrescenta a observação de Bhatt (1999), segundo a qual os modais de raiz devem ser analisados como verbos lexicais, que introduzem sua própria variável de evento, e não como um operador genérico (GEN), como no caso dos modais epistêmicos verdadeiros e dos modais deônticos verdadeiros, o que explica que estes últimos não possam prover uma leitura de acarretamento de realização em um mundo real. Quanto aos modais de raiz, a interpretação genérica será introduzida por outra fonte (o tempo presente, por exemplo), não como uma contribuição intrínseca do modal. Modais de raiz que se alojam na projeção mais baixa são dominados por TP, e a categoria Tempo pode ligar a variável de evento - se for tempo presente, o acarretamento de realização no mundo real não se sustenta, se for passado, a variável de evento é ligada por um operador existencial default, e o tempo passado introduz um acarretamento de realização no mundo real. É o que se depreende de (32), a seguir, extraído de Isac (2015: 56), a partir do dado de Bhatt (1999): ${ }^{23}$

\footnotetext{
${ }^{23}$ A autora faz a ressalva de que o modal no passado pode ter leitura genérica se houver um operador genérico introduzido por um advérbio do tipo 'back in the days' ('no passado'), como ilustrado no contraste entre Yesterday, firemen were able to eat 50 apples/ Back in the days firemen were able to eat 50 apples, em que na primeira existe um acarretamento de realização no mundo real, mas não na segunda.
} 
(32) a. Last night, a masked assailant attacked me on my way home. I was able to wrestle him do the ground (Bhatt 1999, apud Isac 2015: 56)

'[Na] noite passada, um assaltante mascarado me atacou no meu caminho de casa. Fui capaz de empurrá-lo até o chão'.

b. a. Last night, a masked assailant attacked me on my way home. I am able to wrestle so I managed to pin him to the ground.

' $\mathrm{Na}]$ noite passada, um assaltante mascarado me atacou no meu caminho de casa. Sou capaz de derrubar e portanto consegui jogá-lo no chão’.

Com essa discussão, Isac (2015) confirma a hipótese que postula duas posições distintas para os modais: ${ }^{24}$

\begin{abstract}
Root modals are lower than Tense in the syntactic structure, and thus can bind the event variable introduced by the root modal. If the tense operator is generic (i. e present) then no actuality entailment obtain. If, however, the tense is Past, the event variable introduced by the root modal is bound by a default existential operator and the entailment is that the event did take place. In the presence of a GEN operator introduced by an adverbial for example, the event variable of the root modal will be bound by this Gen operator rather than by the default existential operator. In contrast, true epistemic and deontics are higher than Tense, and thus Tense does not have scope over these modals. Moreover, these modals are generic themselves, which, in Bhatt's view, excludes actuality entailments. (ISAC 2015: 56-7)
\end{abstract}

Como nosso interesse se concentra na representação dos imperativos, que, seguindo Isac (2015), se alinham com verdadeiros epistêmicos e deônticos, não levaremos adiante a questão da representação dos modais prioritários e dinâmicos.

Em relação aos elementos modais que são realizados em uma projeção de modalidade mais alta (verdadeiros epistêmicos, verdadeiros deônticos e imperativos), assumimos que são concatenados ao nódulo MP, que é c-comandado pela projeção que hospeda, por hipótese, os traços do Evento de fala/Speech Event (SeP), conforme (31),

\footnotetext{
24 "Modais de raiz estão abaixo de Tempo na estrutura sintática, e, portanto, podem ligar a variável de evento por eles introduzida. Se o operador de tempo é genérico (isto é, presente) então não haverá acarretamento de realização no mundo real. Se, no entanto, o tempo é passado, a variável de evento introduzida pelo modal de raiz, é ligada por um operador existencial default e o acarretamento é o de que o evento efetivamente ocorreu. Na presença do operador Gen introduzido por um advérbio por exemplo, a variável de evento do modal de raiz vai ser ligada pelo esse operador Gen e não pelo operador existencial default. Em contraste, o modal epistêmico verdadeiro e o modal verdadeiro deôntico estão em posição mais alta do que Tempo, e assim Tempo não tem escopo sobre esses modais. Além disso, esses modais são genéricos, os quais, conforme Bhatt, excluem acarretamentos de realização no mundo real." [tradução deste autor]
} 
acima. $^{25}$ Os elementos modais posicionados no núcleo dessa categoria não podem ser restringidos por Tempo, haja vista que o nódulo TP é mais baixo que a variável do evento introduzida pelo modal e, por esse motivo, não pode realizar a ligação. Isac (2015) assume que a ligação é feita pelo núcleo da projeção SeP (Speech Event/SeP), situado na posição mais alta da estrutura oracional.

Seguindo Hacquard (2009), Isac (2015) propõe que o conteúdo de SeP varia com base no tipo de ato discursivo. ${ }^{26} \mathrm{O}$ conteúdo de um SeP declarativo, por exemplo, é o conjunto de crenças do emissor. Nos imperativos, SeP consiste da lista de proposições que o destinatário tem de realizar. Isac ressalta ainda que Hacquard (2009) formula sua proposta com base em Speas e Tenny (2003), citados por Isac (2015), que defendem que os participantes do ato discursivo são representados sintaticamente na estrutura, em núcleos seperados na periferia da oração (uma ideia também complementar ao estudo de Rizzi 1997, dedicado à cisão das categorias que compõem a estrutura do CP).

\subsection{Considerações finais do capítulo}

Com este capítulo, fornecemos evidências para comprovar que as sentenças imperativas possuem um traço que representa um componente semântico modal. A presença desse traço justifica a necessidade de se projetar a categoria Modality Phrase (ModP) em sua sintaxe. A projeção dessa categoria nos permite explicar a existência de diferentes matizes de modalidade nas sentenças imperativas do PB.

Vimos primeiramente que as análises das gramáticas brasileiras são insatisfatórias com relação à explicação da diferenciação entre modo e modalidade e não abordam a modalização de sentenças imperativas. Em seguida, vimos que diversos autores da literatura gerativista já abordaram essas questões. Seguimos, então, com a abordagem de Portner (2007) e de Isac (2015) com o objetivo de demonstrar que as sentenças imperativas possuem uma categoria responsável pela projeção de traços

\footnotetext{
${ }^{25}$ Assumimos que o nódulo Speech Event, situado na projeção mais alta da estrutura, compartilha as propriedades do $\mathrm{CP}$ especializado para o traço optativo, que adotamos em nossa proposta, a ser detalhada adiante.

${ }^{26}$ Isac (2015) faz a ressalva de que, ao assumir que SeP codifica os tipos de ato de fala, não postula a existência de um verbo performativo elíptico a selecionar os traços que definem cada ato de fala (nos termos da Performative Hypothesis, de Ross 1970), uma ideia contestada amplamente desde Levinson (1983, citado por ISAC 2015: 60), que demonstra não haver equivalência no valor de verdade de sentenças como (i) e (ii), em que (i) será verdadeira pelo simples fato de ter sido enunciada por um falante (no caso 'eu'), mas (ii) não o será:

(i) I state to you that the Earth is flat

(ii) The Earth is flat.
} 
modais na sintaxe e que as sentenças imperativas projetam esses traços em uma posição relativamente alta na estrutura, isto é, imediatamente posterior à categoria $\mathrm{CP}$.

No próximo capítulo, observaremos como se dá o funcionamento do $\mathrm{CP}$ diretivo/optativo e como essa categoria dá suporte para nossa análise. Assim, desenvolveremos a hipótese de que o modo imperativo no PB ocorre em uma configuração em que o núcleo da categoria $\mathrm{C}$ é marcado para um traço diretivo-optativo, não exigindo o movimento do verbo para $\mathrm{C}$ como ocorre no PE. Veremos que essa projeção é responsável pelo acionamento de um operador optativo que, somado à força diretiva de segunda pessoa, representa uma expressão volitiva implícita [Quero/que] que licencia a ocorrência da oração imperativa marcada pela modalidade irrealis/ optativa preservando a generalização de que o modo subjuntivo, que é o modo por meio do qual se constroem as estruturas supletivas. Essa configuração, somada à projeção dos traços de modalidade na categoria ModP, explica sintaticamente os diferentes matizes de modalidade associadas às sentenças imperativas no PB.

Além disso, esse tipo de configuração permite a neutralização das formas de indicativo e subjuntivo na expressão do paradigma supletivo do imperativo no PB. No intuito de explicar a ocorrência de sujeitos abertos em posições distintas nas sentenças imperativas, veremos que essa configuração também possibilita licenciar sujeitos em posição pré-verbal ou mesmo pós-verbal em sentenças imperativas. Essa mesma característica possibilita a ocorrência de marcadores negativos em sentenças imperativas no $\mathrm{PB}$, ao contrário do $\mathrm{PE}$, em que as sentenças imperativas negativas com a forma verdadeira são agramaticais. A análise sobre os marcadores negativos, porém, será desenvolvida posteriormente. 


\section{CAPÍTULO 3}

\section{A CONFIGURAÇÃO OPTATIVA-DIRETIVA NAS SENTENÇAS IMPERATIVAS DO PB}

\subsection{Objetivos do capítulo}

O objetivo deste capítulo é apresentar uma hipótese a respeito da configuração estrutural das sentenças imperativas no português brasileiro (PB).

Seguindo a proposta de Isac (2015), assumimos que línguas que possuem a oposição sistemática entre imperativo verdadeiro e supletivo podem ser diferenciadas em termos da finitude da categoria de modalidade, ou seja, pelo fato de o imperativo verdadeiro ocorrer em uma configuração não-finita, não compartilha traços com categorias c-comandadas. Assim, nas sentenças com imperativo verdadeiro, os traços sempre são checados em $\mathrm{C}$ e o sujeito dessas sentenças é obrigatoriamente idêntico ao Destinatário (segunda pessoa). Já a forma supletiva, é finita, apresenta traços phi, o que resulta no fato de que a categoria Mod (Modality) transmite esses mesmos traços para o núcleo funcional que a seleciona. Assim, Isac conclui que a existência de um traço de pessoa permite que sentenças com a forma supletiva possuam inclusive sujeitos de terceira pessoa.

A oposição entre esses sistemas não é suficiente para resolver as questões presentes no $\mathrm{PB}$, haja vista que a perda da categoria Modo no sistema flexional do verbo no imperativo (representado pela ausência da morfologia da forma verdadeira) não permite a formação do contraste em termos da presença/ausência de traços phi e da finitude.

Nossa hipótese é a de que as mudanças que o PB sofreu (a reanálise do sistema pronominal; a neutralização das formas do indicativo e do imperativo, as inovações na sintaxe do sujeito, as inovações em relação à sintaxe da negação - estas últimas a serem tratadas no capítulo 4 - interagem com as propriedades do CP imperativo, o que desencadeia a reestruturação da gramática do imperativo no PB. Dessa maneira, propomos que o PB apresenta um sistema uniforme, caracterizado por um CP 
imperativo, que possui um núcleo funcional que inclui um operador semântico (EX) relacionado à primeira pessoa (emissor), pelo qual é codificada uma força ilocucionária expressiva que se realiza por uma escala, que permite ao emissor direcionar ao destinatário a mensagem imperativa com diferentes matizes (ordem, pedido, súplica). Esse operador representa uma expressão volitiva desiderativa implícita, que licencia a ocorrência de um enunciado marcado pela modalidade optativa. O traço optativo é, por sua vez, relacionado a um traço diretivo, que seleciona a presença da segunda pessoa do discurso - como destinatário do ato de elocução -, o que configura a enunciação da sentença imperativa. Esse traço diretivo encontra-se na projeção da categoria ModP, selecionada pelo CP optativo.

A análise é desenvolvida com base na proposta de Grosz (2011) a respeito da configuração optativa. Grosz postula a presença de um operador EX, que codifica a força ilocucionária/ expressiva optativa, introduzida pelo falante, que denota uma modificação da proposição numa escala contextualmente determinada. Nossa hipótese relaciona sentenças imperativas à modalidade optativa em razão das seguintes propriedades: (i) enunciados optativos expressam desejo, arrependimento, esperança, súplica (características que exibem a relação sujeito-destinatário idêntica ao imperativo) sem a presença de um item lexical correspondente a essas denotações; (ii) apresentam material em C (no inglês é possível inserir complementadores do tipo if, that; verbo/auxiliar finito, segundo Grosz (2011))

Em seguida, apresentamos a análise de Zanuttini et al. (2008) a respeito da configuração Jussiva (Jussive Phrase) como codificadora dos enunciados imperativos. Relacionamos o sintagma jussivo às sentenças imperativas do PB por essa configuração possuir um sistema especializado, em relação à da $2^{\mathrm{a}}$ pessoa do discurso, que, associada à realização sintática do operador EX, permite a codificação do falante e do ouvinte na estrutura do enunciado imperativo. Essa configuração permite a associação do uso uniforme das formas verbais supletivas na realização dos enunciados imperativos no PB a sujeitos abertos em posição pré-verbal (na ordem SV).

Ainda a respeito da configuração do $\mathrm{CP}$ imperativo no $\mathrm{PB}$, investigamos as implicações dessa análise para a proposta apresentada por Isac (2015), que defende a existência de uma projeção funcional para sentenças imperativas caracterizada pela presença de uma categoria específica responsável por hospedar os traços de segunda pessoa. Essa configuração é denominada Speech Phrase (SeP). 
Após a apresentação das análises prévias, partiremos para a apresentação de nossa proposta para as sentenças imperativas no PB. Como será demonstrado, a configuração do $\mathrm{CP}$ imperativo no $\mathrm{PB}$ inclui a projeção de núcleos funcionais que hospedam os traços EX e phi de $1^{\mathrm{a}}$, e os traços JUS e de $2^{\mathrm{a}}$ pessoa, além do traço EPP. Nessa configuração, será possível dar conta da realização de sujeitos abertos pré-verbais na sentença imperativas do PB, que configuram propriedades inovadoras do imperativo, em relação às propriedades sintáticas presentes nas sentenças com a forma verdadeira.

\subsection{Caracterização das sentenças imperativas: aspectos gerais}

Conforme amplamente descrito na literatura, e também no capítulo inicial desta tese, a oração imperativa é um tipo básico de sentença, assim como as sentenças declarativas, exclamativas e interrogativas. Sentenças desses quatro tipos possuem ocorrência atestada universalmente. Cada um desses tipos de sentença apresenta uma função comunicativa diferente (ordenar, declarar, exclamar e interrogar), a que é possível associar diferentes características morfossintáticas. Na perspectiva gerativa, os tipos frasais passam a ter um tratamento formal com a postulação de um campo da estrutura oracional relacionado à codificação da força ilocucionária imperativa, declarativa, exclamativa, interrogativa. Destaca-se a contribuição de Rizzi (1990, 1997), a que se somam diversos estudos que seguiram sua análise.

As sentenças imperativas são caracterizadas de maneira peculiar em relação aos outros tipos frasais. Entre as principais características das sentenças imperativas podemos citar a obrigatoriedade de que o sujeito seja de segunda pessoa, sendo o destinatário do ato discursivo, ao passo que, em declarativas e interrogativas, é possível compor uma combinação diversificada de relação entre pessoa e número. A assimetria que sentenças imperativas apresentam em relação aos outros tipos de sentença, no que se refere à ocorrência de outras pessoas do discurso, indica a importância do componente pragmático na constituição do paradigma imperativo: em razão de não ser possível expressar a primeira ou a terceira pessoas nessas sentenças (embora pronomes de terceira pessoa possam ser empregados em sentenças imperativas, mediante a gramaticalização de sistemas de honoríficos e de polidez), a realização de sujeito aberto pode parecer redundante (Portner 2004; van der Wurff 2007; Zanutinni 2008; entre outros). 
Outra restrição apresentada por sentenças imperativas, referida na literatura (cf. ZANUTTINI 2008), diz respeito à categoria gramatical tempo, que apresenta um conjunto bastante restrito de possibilidades. O tempo em sentenças imperativas limita-se ao presente ou a um futuro próximo. Não há a possibilidade de ocorrência de sentenças imperativas no passado, em contraste com o amplo paradigma verbal, que compõe sentenças declarativas e interrogativas. Essa restrição pode ser formulada em termos da exigência de que o tempo do imperativo seja avaliado em relação ao momento de fala, conforme observado em Isac (2015). Tal propriedade parece interagir com a leitura modalizada dos imperativos, diante da possibilidade identificá-los com os modais de sentenças raiz (conforme demonstrado no Capítulo 3).

\subsection{Enunciados optativos: a análise de Grosz (2011)}

Grosz (2011) assume que as construções optativas são orações que expressam desejo, esperança ou vontade sem apresentar um item lexical que represente essas noções, conforme descrito na literatura (cf. Quirk et al. 1972, 1985; Scholz 1991; Rosengren 1993; citados por Grosz (2011; 13), entre muitos outros). Na discussão, exclui que enunciados optativos sejam expressões formulaicas, contestando o argumento que menciona a presença sistemática de partículas do tipo if only (="se pelo menos'), do inglês. Citando o trabalho de Rifkin (2000), o autor demonstra que os elementos da expressão mudam de posição na estrutura oracional, em inglês, além de terem correspondentes em outras línguas - o que sugere que não são acidentais. Propõe ainda que esses enunciados são variantes de enunciados exclamativos.

Nessa argumentação, o autor avança no sentido de reformular o argumento de Rifkin (2000) de que optativas são determinadas pela presença da partícula do tipo only (Hipótese optativa-only), ao demonstrar que outras partículas podem ser usadas, como at least, com diferença de significado (no sentido de implicar um desejo mais modesto), ou de haver línguas em que somente a partícula correspondente a at least ocorre (como o Português Brasileiro). A consequência é que o enunciado optativo não será determinado pela presença da partícula, conforme será demonstrado adiante.

A análise de Grosz (2011) parte do contraste entre as sentenças optativas e as exclamativas polares, que denotam surpresa ou espanto. Seu objetivo é compreender a forma como as configurações sintática, semântica e pragmática se relacionam nessas sentenças por meio das propriedades que apresentam. Nesse sentido, propõe que sentenças optativas e exclamativas polares contêm um operador semântico EX 
(abreviação para 'expressivo'/ 'exclamativo'), dedicado a expressar a emoção do enunciador. EX seleciona um escala contextualmente saliente, denotando que a proposição modificada excede um limite saliente nessa escala (p. 14) ${ }^{27}$. A diferença é que enunciados exclamativos polares selecionam uma escala de não probabilidade (unlikelyhood).

Além disso, Grosz (2011) propõe que o modo semântico presente nessas construções não é codificado por EX - uma condição para analisar uniformemente optativas e exclamativas (polares). O modo encontra-se, portanto, em um núcleo independente, do tipo Mood/ Modo, cujo conteúdo formal determina o modo morfológico e o material linguístico presente em $\mathrm{C}$.

A essas propriedades vem somar-se a presença das partículas, que, segundo Grosz (2011), atuam como gatilhos que interagem com a 'optatividade' das sentenças. Esses gatilhos de três maneiras diferentes: (i) transmitindo informações a respeito da proposição modificada, (ii) eliminando alternativas de ambiguidade e (iii) ao eliminar as ambiguidades, tornando as partículas licenciadoras ideais para marcar o tipo de elocução desejada.

Segundo o autor, sentenças optativas permitem variação na sua periferia esquerda. Ao analisar sentenças do inglês, Grosz afirma que, em primeiro lugar, essa variação pode ser representada por meio das partículas if e that.

(1) a. Oh, that I had told them both a year ago!

'Oh, que eu tinha dito a ambos um ano atrás!'

(Martin F. Tupper. 1851. The Twins; A Domestic Novel. Hartford: Silas Andrus.)

b. If only I had told them both a year ago!

'Se eu tivesse dito a ambos um ano atrás!'

(GROSZ 2011:13)

Em segundo lugar, Grosz propõe que construções optativas podem variar em termos das partículas prototípicas que contêm (only, but);

(2) a. If I'd only listened to my parents!

\footnotetext{
${ }^{27}$ Traduzido de Grosz (2011: 13): "EX selects a contextually salient scale and conveys that the modified
} proposition exceeds a salient threshold on that scale." 
'Se eu apenas tivesse ouvido meus pais!'

b. If I could just make them understand my point of view!

'Se eu apenas os fizesse entender meu ponto de vista!'

c. If I could but explain!

'Se eu pudesse explicar!'

(Quirk et al. 1985:842)

d. Oh that Apollo would but drive his horses slowly, that the day might be three hours longer; for it is too soon to depart, $[\ldots]$

'Oh, se Apollo guiasse seus cavalos mais lentamente, o dia poderia ter três horas a mais, pois é tão cedo para partir, [...]

(A. Marsh. 1682. The Ten Pleasures of Marriage. London: The NavarreSociety.)

(GROSZ 2011:13)

Acrescenta que falantes de inglês compartilham a intuição de que, em (3), excluídas as partículas 'only/but' em (2a-b), as sentenças não são optativas bem formadas. Em contraste, parecem ser sentenças condicionais incompletas.

a. *If I'd listened to my parents!

'Se eu tivesse ouvido meus pais!'

b. *If I could make them understand my point of view!

'Se eu os fizesse entender meu ponto de vista!'

(GROSZ 2011:15)

Grosz (2011) pergunta se é possível derivar o significado de uma sentença optativa como (2a) da composição do significado padrão de uma if-clause e do significado padrão apenas da partícula. Observando os dados em (3a-b), Grosz rejeita a ideia de que enunciados optativos surjam de composição a partir unicamente do significado padrão de if-clauses e do significado padrão de elementos com only, but. Em contraste, argumenta que enunciados optativos são inerentemente independentes da presença de tais partículas. Para explicar a distribuição de tais partículas, o autor defende que a semântica das partículas conspira com a semântica de um enunciado optativo, fazendo com que essas partículas tenham características optativas. 
Em primeiro lugar, justifica que expressões optativas são uma variante de enunciados exclamativos pela presença de um operador EX nulo. EX seleciona uma escala contextualmente saliente e impede que a proposição modificada exceda um limite saliente nessa escala - itens do tipo 'if' e 'that' podem ser complementos de EX. Em optativas, a escala relevante reflete a preferências do falante (cf. (4)). Crucialmente, o significado lexical do operador EX é fraco. Simplesmente indica que a proposição modificada está em posição relativamente alta em um dado nível dessa escala.

(4) a. EXScale:Speaker-Preferences [(oh) that I had told them both a year ago]!/EscalaEX: Preferências-falantes [(oh) que eu tenha dito a eles no ano passado]!

b. EXScale:Speaker-Preferences [if only I had told them both a year ago]!/ EscalaEX: Preferências-falantes [se somente eu tivesse dito a eles um ano atrás.]

c. $\quad$ Core meaning (due to EX): [p I told them both a year ago] ./ Significado central (devido a EX): [p Eu disse a eles um ano atrás] excede o limite $\xi$ em uma escala que reflete as preferências do falante no contexto enunciado

(GROSZ 2011:14)

A análise de Grosz trata vários tipos de exclamações uniformemente, incluindo exclamativas polares (enunciados que expressam surpresa em relação a um fato) (cf. (5a)), ao postular que tais exclamativas contêm o operador EX. Exclamativas polares só diferem de enunciados optativos na escala que selecionam (aproximadamente: improbabilidade) (cf. (5b)).

a. That you could ever want to marry such a man!

'Você poderia querer casar com um homem assim!'

(Quirk et al. 1985:841)

b. EXScale:Speaker-Unlikelihood [that you could ever want to marry such a man]! / EscalaEX: Preferências-falantes-Improbabilidade [você poderia querer casar com um homem assim]

(GROSZ 2011:14) 
Grosz (2011) argumenta que as partículas do tipo only, just, but, em enunciados optativos envolvem leituras mais fracas. Nessa discussão, defende que existem dois tipos de partícula only, a saber o prototípico $\mathrm{ONLY}_{1}$, que significa 'não mais do que', e o $\mathrm{ONLY}_{2}$, que detém um significado vácuo do ponto de vista do valor verdade, e expressa o nível 'baixo' da proposição que modifica em uma escala de saliência. $\mathrm{ONLY}_{2}$ é definido como o tipo de partícula que ocorre nos enunciados optativos. Crucialmente, essa definição conduz à seguinte conclusão:

\begin{abstract}
It follows that optativity does not compositionally arise from the presence of the particles only, just or but, I argue that their quasi-obligatoriness is due to the following semantic conspiracy (...) EX contributes generalized exclamativity, one shade of which is optativity, while particles (such as $\mathrm{ONLY}_{2}$ ) contribute non-truth-conditional meaning. The contribution of $E X$ is thus orthogonal to that of the particles. (GROSZ 2011: 15) $)^{28}$
\end{abstract}

Para exemplificar, o autor utiliza os dados a seguir: (6a) tem uma leitura optativa marcada, dada em (6c). No entanto, a leitura em (6b) é não optativa e não marcada (infeliz para a leitura condicional, porque incompleta). Grosz propõe que o bloqueio da letura em (6c) se dá em razão de princípios extra-gramaticais.

a. * If I'd listened to my parents!

'Se eu tivesse ouvido meu pais!'

b. unmarked reading: *conditional antecedent

(infelicitous, because incomplete)/ leitura não-marcada: antecedente condicional (infeliz, porque incompleta)

c. marked reading: ok optative utterance (good, but somehow blocked)/ leitura marcada: ok, para enunciado optativo (boa, mas bloqueada de alguma forma)

(GROSZ 2011:15)

\footnotetext{
${ }^{28}$ Segue-se que a optatividade não decorre composicionalmente da presença das partículas only, just e but, meu argumento é que sua quase obrigatoriedade se deve à seguinte conspiração semântica (...) $E X$ contribui para a exclamatividade generalizada, um dos tipos sendo optatividade, enquanto as partículas (como $\mathrm{ONLY}_{2}$ ) agregam um significado não baseado no valor de verdade. A contribuição de $E X$ é, portanto, ortogonal à das partículas. [tradução deste autor]
} 
$\mathrm{O}$ autor defende que as partículas têm leituras marcadas, devido a implicaturas que desencadeiam ou devido à incompatibilidade com leituras não marcadas, o que inverte preferências interpretativas.

(7) a. If I'd only listened to my parents!

'Se eu apenas tivesse ouvido meus pais!

b. dispreferred unmarked reading: * conditional antecedent/ leitura nãomarcada não preferida: * para antecedente condicional

c. preferred marked reading: ok optative utterance/ leitura marcada preferida: ok para enunciado optativo

(GROSZ 2011:16)

Para explicar a não aceitabilidade de (6a), Grosz (2011) propõe que, para garantir o sucesso da comunicação, os participantes do discurso utilizam partículas para garantir uma leitura marcada sempre que o contexto não for suficiente para eliminar uma leitura menos marcada. Correspondentemente, o ouvinte interpretará declarações desprovidas de partículas de acordo com viés contextual (ou seja, prioritariamente como probabilidade). Dado que as leituras não marcadas têm uma probabilidade mais elevada, (7a) sempre será interpretada (e pretendida pelo orador) como o fragmento condicional em (7b) e não como a optativa em (7c). Dessa forma, é derivada a quase obrigatoriedade de partículas em optativas. ${ }^{29}$

$\mathrm{O}$ autor argumenta, portanto, contra uma abordagem em que o significado de partículas é um ingrediente da composicionalidade do traço desiderativo presente nos enunciados optativos. Contrariando esse ponto de vista, demonstra que o significado central de um enunciado optativo é independente dos significados das partículas que contém, mas os dois componentes do significado conspiram para dar origem à quaseobrigatoriedade de tais partículas.

\footnotetext{
${ }^{29} \mathrm{O}$ autor cita o português brasileiro para mostrar que as línguas variam quanto à partícula que ocorre nesse tipo de contexto. No caso, o correlato de 'only' 'só/somente' não ocorre, e sim o de de 'at least', que no PB é 'pelo/ao menos', conforme (i) e (ii), extraídos de Grosz 2011: 37). O autor não menciona, porém, que o português brasileiro dispensa qualquer partícula, conforme ilustrado em (iii) - nesse sentido, a opcionalidade da partícula constitui um argumento adicional para a proposta do autor:

(i) *Ah, se só João tivesse ouvido a Maria!

(ii) $\mathrm{Ah}$, se ao menos João tivesse ouvido a Maria!

(iii) Ah, se (ao menos) João tivesse ouvido a Maria!
} 
Nessa perspectiva, Grosz (2011) aprofunda a discussão sobre o estatuto das optativas, pela demonstração de como se identificam com enunciados exclamativos (polares), e ainda pela indicação dos argumentos que justificam a existência das exclamativas polares do tipo V1 em oposição às declarativas do tipo V1, no alemão, em que a ocupação da periferia da oração $(\operatorname{specCP})$ tem caráter restritivo, por ser uma língua do tipo padrão V2. Desta forma, ressalta que optativas e exclamativas polares (i) podem assumir a forma de orações introduzidas por que (that-clauses) e de orações do tipo V1; (ii) são usadas para exclamar; (iii) indicam uma comparação entre a proposição expressa e seu conteúdo oposto, já que a optativa denota o que se deseja, enquanto sua negação é o que efetivamente ocorre, ao passo que a exclamativa polar denota o que surpreendentemente ocorre, enquanto sua negação é o que se espera (p. 41).

$\mathrm{Na}$ sequência da argumentação, o autor demonstra que exclamativas polares do tipo V1 efetivamente existem (contra argumentos que as identificam com perguntas V1 e declarativas do tipo V1 com apagamento de specCP). Dessa forma, contesta a hipótese de que exclamativas polares V1 são declarativas V2 em que um elemento (do tipo pronome temporal ou situacional) em specCP é apagado, uma possibilidade apontada por Scholz (1991), com base em Oppenrieder (1989), citados pelo autor.

Grosz (2011) demonstra que exclamativas polares V1 em alemão não são casos de inversão narrativa ou de apagamento de tópico, duas propriedades bem estabelecidas de declarativas V1 nessa língua. Tomando-se como referência a inversão narrativa, por exemplo, a pergunta é se é possível excluir as exclamativas polares V1. O autor parte da observação de Önnerfors (1997b) de que as exclamativas V1 se identificam com a inversão narrativa por não ocorrerem como resposta a uma pergunta (cf. (8), extraído de Grosz (2011: 49) - com glosa e tradução nossa).

\author{
A: Was war los? \\ what was up/ o que foi PRT \\ 'What happened?'/ 'O que aconteceu?'
}

B1: Da stand plötzlich ein Mann vor der Tür.

there stood suddenly a man before the door/ ali estava de-repente um homem diante da porta

'Suddenly, there was a man standing in front of the door.'/ 'De repente, havia um homem de pé diante da porta.'

B2: Es stand plötzlich ein Mann vor der Tür.

it stood suddenly a man before the door/ EXPL estava de repente um homem diante da porta 
'Suddenly, there was a man standing in front of the door.'/ 'De repente, havia um homem de pé diante da porta.'

B3: ??Stand plötzlich ein Mann vor der Tür.

stood suddenly a man before the door/ estava de repente um homem diante da porta

'Suddenly, there was a man standing in front of the door.' / 'De repente, havia um homem de pé diante da porta.'

(Önnerfors 1997b:51)

No entanto, uma diferença é que, contrariamente às estruturas de inversão narrativa, exclamativas polares V1 admitem enunciados genéricos, conforme ilustrado nos pares (9) e (10), extraídos de Grosz (2011: 49/ 50), com glosa e tradução nossa: .

(9) a. *Sind Kritiker Idioten. / Kritiker sind Idioten. are critics idiots/ critics are idiots são críticos idiotas/ críticos são idiotas 'Critics are idiots.'/ 'Críticos são idiotas

(Önnerfors 1997a:306)

b. *Weinen Kinder leicht. / Kinder weinen leicht. cry children easily /children cry easily choram crianças facilmente/ crianças choram facilmente 'Children cry easily.'/ 'Crianças choram facilmente'

(Önnerfors 1997a:307)

Regnet es da plötzlich ins Haus. rains it then suddenly into-the house chove EXPL então de repente dentro de casa

'Suddenly, it's raining into the house.'/ 'De repente, está chovendo dentro de casa.'

(Önnerfors 1997a:302)

Diferentemente, exclamativas polares admitem enunciados genéricos, conforme ilustrado em (11), extraído de Grosz (2011: 51):

(11) a. Haben diese Tiere doch glatt vier Beine! polar exclamative have these animals doch outright four legs têm esses animais PRT de fato quarto pernas '[It's remarkable that] these animals have four legs!'/ '[É impressionante que] esses animais tenham quatro pernas!'

b. Mensch, sind Kritiker doch tatsächlich Idioten! man are critics doch indeed idiots homem são críticos PRT de fato idiotas 'Man, [it's schocking that] critics are really idiots!'/ 'Cara, [é surpreendente que] críticos sejam realmente idiotas!' 
$\mathrm{O}$ autor acrescenta que exclamativas polares V1 não são um tipo de declarativa por denotarem algo que merece destaque, o que não se impõe para declarativas.

A partir desses ingredientes, a análise orienta-se para a definição da estrutura sintática da proposição selecionada pela projeção CP que hospeda o operador EX em specCP. Considerando-se que o estatuto factual de enunciados optativos pode ou não ser pressuposto, o que justifica a realização independente de uma projeção de Modo, o autor propõe que o modo semântico pode ser codificado morfologicamente em dois domínios da oração: no campo medial, pelo verbo flexionado ou pelo auxiliar (no subjuntivo ou no indicativo), na periferia da oração, pelo complementador, os quais interagem com a (im)possibilidade de movimento de (V-para-)T-para-Mood-para-C.

De acordo com a proposta, a presença do material lexical em $\mathrm{C}$ é determinada pela presença do traço EPP em C (e Mood): se C tem o traço EPP (mas não $M o o d)$, o núcleo Mood move-se para $\mathrm{C}$, sem carrear T. No alemão, $[\mathrm{C}+$ Mood $]$ é pronunciado como wenn 'if'. Se C e Mood manifestam o traço EPP, então ocorre V-para-T-paraMood-para-C, resultando na optativa V1. Na ausência de EPP em C, o núcleo C é pronunciado como o complementador dass 'that', considerada a opção default (p. 79). Dessa forma, as pressuposições sobre o estatuto factual são determinadas pelos traços interpretáveis de modo, os quais têm um reflexo na sintaxe aberta, seja em C, seja no domínio do verbo.

A proposta completa está sistematizada a seguir, conforme extraído de Grosz (2011: 79):

$$
\begin{aligned}
& \text { a. } \mathrm{C}_{[\mathrm{uM} \text { Mod, }, \mathbf{E P P}] \ldots} \ldots \text { Mood }[\mathrm{iMood}, \mathrm{uT},+\mathbf{E P P}] \ldots \mathrm{T}[\mathrm{iT}] \\
& \rightarrow \mathrm{C}_{[\mathrm{uM} \text { Mood }]} \ldots \mathrm{T}[\mathrm{iT}]+\operatorname{Mood}[\mathrm{iMood}, \mathrm{uT}] \ldots\left\langle\mathrm{T}_{[\mathrm{iT}]}\right\rangle \\
& \rightarrow \text { spell-out: } \mathrm{C}_{[\mathrm{uMood}]} \Leftrightarrow \square \text { dass 'that'/'que' }
\end{aligned}
$$

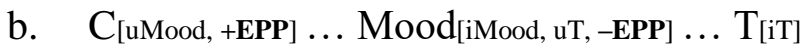

$$
\begin{aligned}
& \rightarrow \operatorname{Mood}_{[\mathrm{iMood}, \mathrm{uT}]}+\mathrm{C}_{[\mathrm{uMood}]} \ldots\left\langle\operatorname{Mood}_{[\mathrm{iMood}, \mathrm{uT}] \ldots \mathrm{T}[\mathrm{iT}]}\right. \\
& \rightarrow \text { spell-out: } \operatorname{Mood}[\mathrm{iMood}, \mathrm{uT}]+\mathrm{C}_{[\mathrm{uMood}]} \Leftrightarrow^{\mathrm{TM}} \text { wenn 'if'/'se' } \\
& \text { c. } \quad \text { C }[\text { uMood, }+ \text { EPP }] \ldots \text { Mood }[\text { iMood, uT, }+\mathbf{E P P}] \ldots \mathrm{T}[\mathrm{iT}] \\
& \left.-\rightarrow \mathrm{C}_{[\mathrm{uMood},+\mathrm{EPP}]} \ldots \mathrm{T}[\mathrm{iT}]+\operatorname{Mood}_{[\mathrm{iM} \text { Mod, }} \mathrm{uT}\right] \ldots\left\langle\mathrm{T}_{[\mathrm{iT}]}\right\rangle \\
& -\rightarrow\left[\mathrm{T}_{[\mathrm{iT}]}+\operatorname{Mood}_{[\mathrm{iMood}, \mathrm{uT}]}\right]+\mathrm{C}_{[\mathrm{uMood}]} \ldots\left\langle\left\langle\mathrm{T}_{[\mathrm{iT}]}+\operatorname{Mood}_{[\mathrm{iMood}, \mathrm{uT}]}\right\rangle \ldots\left\langle\mathrm{T}_{[\mathrm{iT}]}\right\rangle\right. \\
& \text { spell-out: }\left[\mathrm{T}_{[\mathrm{iT}]}+\operatorname{Mood}_{[\mathrm{iMood}, \mathrm{uT}]}\right]+\mathrm{C}_{[\mathrm{uMood}]} \Leftrightarrow \mathrm{V} 1
\end{aligned}
$$

(13) a. dass 'that' spells out $\mathrm{C}$ on its own./ 'que' pronuncia $\mathrm{C}$ sozinho.

b. wenn 'if' spells out [C [Mood]]./ 'se' pronuncia [C [Mood]]. 
c. $\quad V 1$ spells out $[\mathrm{C}[\mathrm{T}[\mathrm{Mood}]]] . / \mathrm{V} 1$ pronuncia $[\mathrm{C}[\mathrm{T}[\mathrm{Mood}]]]$.

O autor conclui:

For languages like German and Dutch, the view that overt material in $\mathrm{C}$ is a realization of $C, C+\operatorname{Mood}$ or $C+M o o d+T$ derives the complementarity of 'complementizers' and V-to-C movement, originally observed by den Besten (1983) (p. 79)..$^{30}$

Em resumo, a proposta de Grosz é interessante para nosso trabalho por apresentar diversas características que os enunciados optativos possuem e que, de acordo com nossa hipótese, também podem ser identificados em sentenças imperativas no PB. Para Grosz, os enunciados optativos são caracterizados (i) pela expressão do modo optativo independentemente da presença de itens lexicais, sendo realizada por meio da estrutura sintático-semântica da sentença; (ii) pelo fato de enunciados optativos conterem um operador semântico EX, na periferia da oração, dedicado a expressar a emoção presente na elocução, em uma escala definida contextualmente, que modela as preferências do falante; (iii) por possuírem uma representação sintático-semântica que determina a realização morfológica de itens por meio do material presente em C; (iv) por demonstrar que os complementadores do tipo if, that; verbo/auxiliar finito atuam como representantes do operador semântico optativo e não atuam como definidores do caráter optativo da sentença, ou seja, os complementadores apenas manifestam a existência do traço optativo; (v) por indicarem a diferenciação do modo gramatical: contrafactual (=subjuntivo) vs. não-contrafactual (=indicativo); (vi) por assumirem que a presença de partículas como only, at least, doch (do inglês e do alemão), consideradas modificadores proposicionais, são inseridas nas construções optativas em função do operador semântico - e não o contrário -, o que marca a independência da estrutura optativa de operadores lexicais.

A análise de Grosz (2011) dos enunciados optativos será adotada nesta tese na discussão das características dos enunciados imperativos do português brasileiro. Conforme mencionado, a hipótese de trabalho é a de que os enunciados imperativos do PB se estruturam em uma configuração optativa, nos termos da proposta por Grosz (2011), embora seja incluída projeção adicional, que codifica a força ilocucionária

\footnotetext{
30 "Em línguas como o alemão e o holandês, a concepção de que material lexical em C é a realização de $\mathrm{C}, \mathrm{C}+$ Mood, ou C + Mood $+\mathrm{T}$ deriva a complementaridade entre 'complementadores' e movimento de $\mathrm{V}$ para-C, conforme originalmente observado por den Besten (1983)" [tradução deste autor].
} 
diretiva (jussiva), nos termos de Zanuttini (2008), além de especificações a respeito das propriedades formais do núcleo Mood, como será demonstrado a seguir.

\subsection{A força diretiva nas sentenças imperativas: a proposta de Zanuttini (2008)}

A análise de Zanuttini (2008) estrutura-se em termos da hipótese de que a força ilocucionária nas sentenças imperativas está associada à relação entre a noção de destinatário e o licenciamento da posição de sujeito em orações imperativas. Entre as hipóteses apresentadas, a autora menciona que a representação sintática das sentenças imperativas contempla a noção de destinatário por meio de uma projeção funcional com traços de segunda pessoa, a projeção ‘jussiva' (Jussive Phrase, doravante JP), que entra em relação sintática com o argumento na posição de sujeito, compartilhando os traços de pessoa.

Retomando a investigação de Portner (2004) acerca das propriedades únicas de sujeitos imperativos, Zanuttini (2008) observa a existência de quatro tipos de sentenças imperativas em inglês, que são aceitas por todos os falantes. São elas: (i) imperativas com sujeitos nulos, (ii) imperativas com pronome expresso 'you' (2p); (iii) imperativas com alguns sujeitos quantificacionais, e (iv) imperativas com nomes nus (ver exemplos adiante). Em relação às sentenças imperativas com sujeitos nulos, os traços de $2^{\mathrm{a}}$ pessoa são identificados, uma vez que é possível ligá-los com pronomes e anáforas de $2^{\mathrm{a}}$ pessoa, como em (14a-b). Isso também é confirmado pelo fato de que, quando é seguido por uma 'tag question', o pronome na 'tag question' é de $2^{\mathrm{a}}$ pessoa, como em (14c-d).

(14) a. Raise your hand!

'Levante suas mãos!'

b. Wash yourselves!

'Lavem-se!'

c. Raise your hand, won't you?

'Levante suas mãos, você não vai?

d. Wash yourselves, won't you?

Lavem-se, vocês não vão?

(ZANUTTINI 2008: 187). 
Em relação à estrutura morfológica, Zanuttini (2008) observa que, nas línguas, o paradigma imperativo tem um número pequeno de formas. Quando tem apenas uma forma, como no inglês, sujeitos nulos são interpretados como segunda pessoa. Segundo Zanuttini (2008), isso é um puzzle por dois motivos: línguas não ProDrop como o inglês permitem sujeitos nulos em orações não finitas, onde há interpretação genérica ou controlada, como ilustrado em (15a) e (15b), respectivamente. A interpretação de imperativas não é, no entanto, nem genérica, nem controlada, mas se refere a um conjunto de destinatários ou a conjuntos que contenham destinatários, conforme ilustrado em (15c-d).

(15) a. $\mathrm{PRO}_{\text {Arb }}$ hiking is popular.

'Caminhar é popular.'

b. $\mathrm{He}_{\mathrm{i}}$ likes $\mathrm{PRO}_{\mathrm{i}}$ to hike.

'Ele gosta de caminhar'

c. Eat!

'Coma!'

d. Don't leave now!

'Não saia agora!'

(ZANUTTINI 2008: 188).

O contraste em (15) é importante porque demonstra que o sujeito nulo de imperativas não é o mesmo sujeito nulo de orações não finitas. Em razão de ser reduzido o paradigma imperativo, o mecanismo de licenciamento de sujeitos nulos em imperativas também não é o mesmo que nas declarativas ou interrogativas. Os exemplos do italiano (abaixo) ilustram, contrastivamente em relação ao inglês, a presença de uma vogal temática no paradigma imperativo, conforme ilustrado em (16). No italiano, a presença da vogal temática como demarcadora da estrutura morfológica das formas imperativas corresponde, portanto, ao que é descrito na literatura como o 'imperativo verdadeiro', em oposição às formas ditas supletivas, em que é acionado o paradigma do subjuntivo (conforme referido no Capítulo 1).
(16) a. Mangia!
(Italiano)
'Eat!'/ 'Come!' 
b.Bevi!

'Drink!'/ 'Bebe!'

c. Vieni!

'Come!'/ 'Vem!'

(dados extraídos de Zanuttini 2008: 189, com tradução nossa)

Diferentemente, porém, o italiano é uma língua ProDrop, que permite sujeitos nulos em orações finitas. Por hipótese, a possibilidade de identificação e licenciamento de sujeito nulo deve-se exatamente pelo fato de possuir uma morfologia 'um pouco' mais desenvolvida.

Diante desse contraste, Zanuttini (2008) observa que, em inglês, na realização de sujeitos pronominais abertos, um pronome de segunda pessoa pode ser sujeito de um imperativo, mas há restrição à ocorrência dos pronomes de primeira e terceira pessoa. ${ }^{31}$

(17) a. You do it!/ Você fazer IMP isso!

b.*I do it! / Eu fazerIMP isso!

c. ${ }^{*}$ He do it!/ Ele fazer ${ }_{I M P}$ isso!

(ZANUTTINI 2008: 189).

Com os exemplos, Zanuttini (2008) reitera que sentenças imperativas sempre envolvem referência a um destinatário. Além dos exemplos anteriores, é possível ver a possibilidade de compor o paradigma imperativo com sujeitos quantificacionais, conforme ilustrado em (18), extraídos da autora

(18) a. Nobody touch your pencils!

'Ninguém toque seus lápis!'

b. Everyone say hello to the principal!

'Todo mundo diga 'olá' ao reitor'

c. Someone come up to the blackboard and do this problem!

'Alguém venha ao quadro negro e resolva este problema!'

(ZANUTTINI 2008: 190).

\footnotetext{
${ }^{31}$ No caso do PB, a existência o pronome de terceira pessoa (você) no paradigma pronominal imperativo se dá em razão de sua gramaticalização como categoria associada à $2^{a}$ pessoa do discurso, conforme referido no primeiro capítulo desta tese. Retornaremos ao preenchimento da posição de sujeito no PB.
} 
Esses sujeitos diferem de sujeitos quantificacionais em outros tipos de orações por dois motivos. Primeiramente, a interpretação quantificacional nas imperativas é restrita a um conjunto limitado de indivíduos, definidos pela propriedade de figurar como destinatários, conforme ilustrado a seguir.

(19) a. Nobody touch your pencils until we start timing the test!

'Ninguém toque seus lápis até que nós comecemos a marcar o tempo!'

b. Everyone do your homework!

'Todos façam seu dever de casa!'

(ZANUTTINI 2008: 190).

A autora acrescenta que sentenças declarativas e interrogativas podem limitar o conjunto de destinatários, mas não o fazem de maneira obrigatória. Para exemplificar a diferença, apresenta a seguinte situação. Considerando-se um contexto em que uma professora destina uma mensagem a uma sala, os quantificadores são naturalmente interpretados como um conjunto limitado de destinatários. Mas, em um contex to em que duas professoras estão conversando, sem uma classe presente, os mesmos quantificadores são interpretados como um conjunto de estudantes que não são destinatários.

(20) a. Nobody should touch their pencils until we start timing the test.

'Ninguém toque seus lápis até que nós comecemos a marcar o tempo!'

b. Did everyone do their homework?

'Todos fizeram seu dever de casa?'

(ZANUTTINI 2008: 190).

A segunda diferença apresentada diz respeito às possibilidades de ligação. Em sentenças imperativas, sujeitos quantificacionais não podem ligar pronomes de terceira pessoa e anáforas, mas apenas pronomes e anáforas de segunda pessoa.

(21) a. Everyone $_{(\mathrm{i})}$ raise $\left(*\right.$ his $_{(\mathrm{i})} /$ her $_{(\mathrm{i})} /$ their $\left._{(\mathrm{i})}\right) / \operatorname{your}_{(\mathrm{i})}$ hand!

'Todos levantem suas mãos!'

b. Someone $(\mathrm{i})$ raise $\left({ }^{*} \operatorname{his}_{(\mathrm{i})} /\right.$ her $_{(\mathrm{i})} /$ their $\left._{(\mathrm{i})}\right) / \operatorname{your}_{(\mathrm{i})}$ hand! 
'Alguém levante sua mão!'

(ZANUTTINI 2008: 190).

A autora inclui então dados em que nomes próprios e nomes nus são usados em estruturas imperativas no inglês, o que requer uma explicação diante de uma possível incompatibilidade desses itens com o traço de $2^{a}$ pessoa. Dessa forma, conforme a autora: "Proper names as subjects of imperatives thus exhibit the characteristic properties of elements with 2nd person features, both from the point of view of interpretation and of binding." (p. 192) ${ }^{32}$

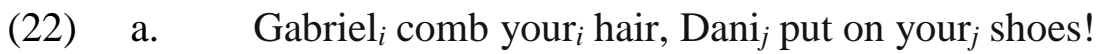

'Gabriel penteie seu cabelo e Dani ponha seus sapatos!'

b. $\operatorname{John}_{i}$ raise your ${ }_{i}$ hand, Mary ${ }_{j}$ wiggle your $_{j}$ fingers!

'John levante suas mãos e Mary mexa seus dedos!'

(23) a. $\quad *$ Gabriel $_{i}$ combed your ${ }_{i}$ hair, while Dani $_{j}$ put on your shoes. $_{j}$ shato

'Gabriel penteou seu cabelo enquanto Dani colocou seus

sapatos.'

b. *Did Gabriel comb your $r_{i}$ hair, while $\operatorname{Dani}_{j}$ put on your ${ }_{j} \operatorname{shoes}$ ?

'Gabriel penteou seu cabelo enquanto Dani colocou seus

sapatos?'

A autora propõe que a ausência do determinante é fator decisivo para o uso de nomes próprios e nomes nus na estrutura imperativa, propondo tentativamente que a fronteira nula do DP viabilizaria o compartilhamento do traço de $2^{\mathrm{a}}$ pessoa em JP com a posição de sujeito, com a consequente possibilidade de ligar o pronome na posição de objeto. ${ }^{33}$

\footnotetext{
32 "Nomes próprios como sujeitos de imperativos exibem, portanto, as propriedades características de elementos com traços de 2 a pessoa, tanto do ponto de vista da interpretação quanto da ligação." [tradução nossa]

${ }^{33}$ Zanuttini (2008) discute ainda dados do inglês em que, para alguns falantes, é possível o uso do determinante na estrutura de sintagmas nominais, na estrutura com interpretação de lista (cf. (i)).

Segundo a autora, trata-se de duas gramáticas distintas, sendo a gramática que autoriza essa possibilidade um correlato de estruturas imperativas em línguas que utilizam formas flexionadas no subjuntivo, em que se postula um núcleo funcional que aloja o traço de $2^{\text {a }}$ pessoa e licencia o sujeito, ao tempo em que bloqueia a relação entre o núcleo Jussivo e o sujeito.
}

(i) The girls straighten their shoulders, the boys lift their chins!" (Zanuttini 2008: 206) 
Considerando as características morfológicas do paradigma imperativo e sua relação com a realização do sujeito, Zanuttini (2008) define que as sentenças com força diretiva contêm uma projeção funcional exclusiva, que permite distinguir o enunciado imperativo de outros tipos de enunciados (assertivos e interrogativos). A autora denomina a projeção funcional responsável por esse tipo de característica de projeção jussiva (JP), em alusão à semântica diretiva, e postula que essa categoria tem um operador no seu especificador que atua como operador lambda acima do sujeito e abstrai sobre o sujeito. Nessa configuração, JP entra em operação de concordância (Agree) com o sujeito, que resulta na ocorrência do traço de pessoa em ambas as posições (no núcleo Jussivo e no sujeito).

Remetendo a Portner (2004), entre outros autores, na caracterização do operador lambda na projeção JP, Zanuttini (2008: 196) define que o operador lambda toma como input uma proposição, abstraindo sobre o sujeito que satura o predicado que a constitui, e gera uma propriedade como output. Essa propriedade, por sua vez, inclui a pressuposição de que argumento que corresponde ao sujeito tem como referente o destinatário (ou a um conjunto que contém o destinatário desejado), ao qual será dirigida uma força diretiva específica (ordem, desejo, convite) pelo componente pragmático. A projeção JP inclui ainda traços de pessoa, os quais não se referem a um indivíduo, mas tão somente introduz na derivação sintática o traço de pessoa. Disso decorre seu estatuto interpretável, obtido pela pressuposição que o vincula ao destinatário.

A projeção JP tem, portanto, traços específicos e interpretáveis de pessoa ${ }^{34}$. Quando os elementos carregam traço de pessoa estruturalmente próximo ao sujeito, o núcleo de JP entra em concordância com o sujeito, resultando em uma relação sintática que resulta no surgimento dos mesmos traços em ambos os lugares (o núcleo de JP e no sujeito). Para atribuição dos traços de pessoa em estruturas em que o sujeito é nulo, Zanuttini segue os requisitos para a ocorrência da relação Agree, de acordo com Chomsky (2000) e conforme revisto em Pesetsky e Torrego (2007). Em particular, assume a ausência de TP ou de traços phi em TP (como no caso dos imperativos com

\footnotetext{
${ }^{34}$ Nos casos aqui apresentados, trata-se de $2^{\text {a }}$ pessoa. No entanto, os autores apresentam casos como o do coreano em que há outras possibilidades de traços de pessoa (cf. Portner, Zanutinni e Pak (2012). Conforme observam Ferreira; Salles (2016), em línguas com um sistema de honoríficos gramaticalizado, é possível supor outras pessoas nesse contexto, bem como a necessidade de que sejam distinguidas em enunciados imperativos das demais pessoas do sistema pronominal. O caso do pronome 'você' pode ser considerado uma forma de gramaticalização de um pronome originalmente situado em um paradigma de honoríficos. Desse sistema resultam formas de polidez, em que são usados pronomes de $3^{\mathrm{a}}$ pessoa, ou de $1^{\mathrm{a}}$ pessoa do plural, com as implicações inerentes quanto à flexão do verbo.
} 
morfologia infinitiva, ou com uma única forma verbal, como no inglês), postulando que a presença de traços não interpretáveis de Caso no DP sujeito propicia a relação sintática entre o núcleo da projeção JP e o sujeito, contando ainda com o fato de que Agree é sensível à localidade e à presença do traço não interpretável de caso (nominativo) no sujeito (o que torna ativo o sujeito para tal operação).

Contudo, se houver um elemento interveniente entre o sujeito e JP, a operação Agree não ocorre - é o caso, por exemplo, de estruturas imperativas em que as formas verbais carregam traços phi, o que habilita a projeção TP a licenciar o traço de caso do sujeito, que é validado como nominativo. A presença da projeção interveniente não exclui o papel de JP, cujo traço associado ao destinatário é interpretável e se mantém ativo. A autora cita dados do islandês, em que é contrastado o uso de forma imperativa sem marca de tempo (infinitiva), sendo o sujeito nulo capaz de ligar o pronome de $2^{a}$ pessoa na posição de objeto (cf. 25a), em oposição ao uso de forma verbal imperativa flexionada na $3^{\mathrm{a}}$ pessoa, em que não é possível a ligação do pronome de $2^{\mathrm{a}}$ pessoa (cf. $25 b)::^{35}$

(24) a. Allir taka upp bækurnar sínar / ykkar. (Icelandic)

All.MASC take.INF up books.the REFL / yours

Todos levar INF PRT livros.os REFL/ 2pl

Everyone pick up your books!/ Cada um pegue seus livros!

b. Allir taki upp bækurnar sínar / *ykkar.

All.MASC take.3.PL.SUBJ.PRES up books.the SELF / yours

Todos levem.3.PL.SUBJ.PRES PRT livros.os REFL/*2pl

Everyone should pick up his books./ Cada um pegue seus livros!

${ }^{35}$ É interessante notar que, diferentemente do islandês, em português (padrão), o imperativo verdadeiro não poderia ser usado, mas tão somente a forma supletiva, cujo sujeito pode ligar o pronome, que, por sua vez, tem referente de $2^{\mathrm{a}}$ pessoa e forma gramatical de $3^{\mathrm{a}}$ pessoa, conforme ilustrado a seguir - essa questão será retomada:

(i) *Cada um pega teus livros.

(ii) Cada um pegue seus livros. 
A autora assume a seguinte estrutura para a projeção de JP.

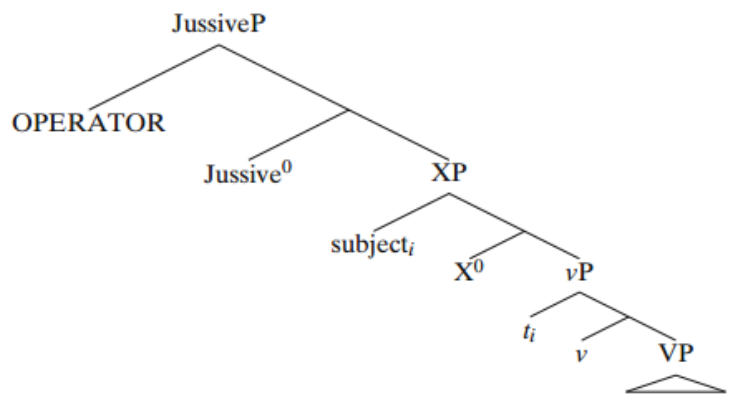

(ZANUTTINI 2008:198)

Dessa forma, nos casos em que o núcleo $\mathrm{X}$ é realizado por um verbo cuja morfologia precisa de traço de pessoa (como nos imperativos formados exclusivamente com a raiz verbal), o núcleo de JP é o elemento com esses traços mais próximo ao sujeito, o qual pode estabelecer a relação por meio de Agree - e assim compartilhar o traço de $2^{\mathrm{a}}$ pessoa nas duas posições. A relação Agree é estabelecida da seguinte forma: o sujeito tem traços de Caso não checados; o núcleo de JP atua como Sonda e entra em relação Agree com o sujeito, validando ou compartilhando o traço de pessoa e validando o traço de Caso. Tendo em vista que JP está presente nas imperativas translinguisticamente, Zanuttini (2008) conclui que todas as línguas permitem sujeitos nulos definidos em imperativas, mesmo quando os traços de pessoa na flexão verbal são fracos ou não ricos o suficiente para licenciar e identificar um sujeito nulo nos outros tipos de sentenças - é o que se confirma pelos dados translinguísticos. ${ }^{36}$

\footnotetext{
${ }^{36}$ Em estudo posterior, Zanuttini (2012) justifica como núcleos múltiplos atuam juntos para licenciar Agree: "though features might enter the derivation through different instances of Merge, when they are in a given local domain they are all accessible to the same syntactic operations." (p. 1.243) [embora entrem na derivação por meio de diferentes ocorrências de Merge, uma vez em um dado domínio local, os traços estão todos acessíveis para as mesmas operações sintáticas]. Segundo a autora, essa possibilidade tem origem no estudo seminal de Pollock (1989), citado pela autora, em que os traços formais de pessoa, número, tempo ocorrem distribuídos em núcleos funcionais distintos, mas são reunidos por movimento de núcleo para licenciar o sujeito em uma relação de concordância. Em nossa análise, essa possibilidade se aplica diante da relação entre o CP marcado para o traço optativo, e JP marcado para o traço jussivo.
} 
Em resumo, a proposta de Zanuttini (2008) capta a existência de uma estrutura imperativa com uma projeção designada JP, que hospeda um operador dedicado à codificação da força diretiva. Nos termos da autora: ${ }^{37}$

\begin{abstract}
In sum, I am proposing that the Jussive Phrase enters an Agree relation with the subject when the TP is missing or lacks $\varphi$-features. By virtue of having $2^{\text {nd }}$ person features and entering an Agree relation with the subject, the Jussive Phrase (a) makes null subjects possible, (b) allows quantificational subjects with null domain restrictions to acquire 2 nd person features and bind $2^{\text {nd }}$ person elements in object position, and (c) enables noun phrases with a null determiner (proper names and bare nouns) to acquire 2 nd person features and bind 2nd person elements. The first property holds cross-linguistically, whenever the verbal form employed by the imperative lacks $\varphi$-features. The others are more restricted.
\end{abstract}

A seguir, veremos a proposta de Isac (2015) que também leva em consideração o estudo de Zanuttini (2008) a respeito das características da projeção Jussiva. No entanto, diferentemente de Zanuttini, propõe que as sentenças imperativas possuem dois eventos de causa, argumentando que é necessária uma estrutura que capte esses eventos.

Conforme demonstrado até o momento, as propostas para a estrutura optativa e jussiva postulam a existência de projeções dedicadas à codificação da $1^{\mathrm{a}}$ pessoa/ falante e da $2^{\mathrm{a}}$ pessoa/ destinatário, respectivamente. É importante notar que tais projeções são associadas a enunciados específicos, diferentemente de análises prévias, em que a codificação desses traços é postulada como propriedades inerentes a todos os enunciados. Mesmo reconhecendo a pertinência de identificar o falante e o destinatário nos enunciados em geral, é relevante investigar as implicações de vincular a realização sintática desses traços, como meio de distinguir os enunciados na interface com a pragmática da comunicação. É a hipótese que pretendemos assumir.

\footnotetext{
37 "Em suma, proponho que o sintagma jussivo (JP) entra em relação Agree com o sujeito quando o TP está ausente ou não manifesta traços-phi. Por manifestar traço de 2a pessoa e por entrar uma relação Agree com o sujeito, o sintagma jussivo (a) torna o sujeito nulo possível, (b) permite que sujeitos quantificacionais com domínio de restrição nulo adquiram traços de $2^{\mathrm{a}}$ pessoa liguem elementos de $2^{\mathrm{a}}$ pessoa na posição de objeto, e (c) habilita sintagmas nominais com determinante nulo (nomes próprios e nomes nus) a adquirir traço de $2^{\mathrm{a}}$ pessoa e ligar elementos de $2^{\mathrm{a}}$ pessoa. A primeira propriedade manifesta-se translinguisticamente, sempre que a forma verbal usada pelo imperativo não tem traços-phi. As demais são mais restritas.” [tradução nossa]
} 


\subsection{A análise sintático-semântica das sentenças imperativas: o estudo de Isac} (2015)

3.5.1 Uma posição na estrutura para o destinatário do ato de elocução

O trabalho desenvolvido por Isac (2015) busca explicar o comportamento de sentenças imperativas verdadeiras e supletivas. Sua hipótese é marcada pela relação dessas sentenças com um núcleo sintático-semântico que apresenta o ato de elocução imperativo com um emissor da sentença e com um destinatário. Sua preocupação é identificar traços morfossintáticos relevantes que expliquem como as sentenças imperativas realizam as proposições e como os atores do ato de elocução participam desse ato.

A evidência considerada pela autora é que os traços morfossintáticos presentes nas sentenças imperativas (EPP, Phi, Caso), que participam da operação Agree de checagem de traços, explicam as diferenças sintáticas entre as formas de sentenças imperativas. Nesse sentido, Isac (2015) propõe novas projeções relevantes na sintaxe imperativa e inclui uma discussão acerca da semântica desses traços.

A autora compartilha a visão presente em estudos prévios (Zanutinni 2003, Zanutinni 2008 e Zanutinni et al. 2012) a respeito da existência de categorias funcionais que podem ser identificadas exclusivamente em sentenças imperativas. A autora defende a existência de uma categoria para a modalidade nas sentenças imperativas Modality Phrase (ModP), postulada no capítulo anterior com base na argumentação de Isac (2015) (também assumida no âmbito da proposta de Grosz (2011) para orações optativas, ver seção 3.3) - que interage com uma projeção codificadora do evento de fala, rotulada Speech event Phrase (SeP) - que capta as relações de elocução presentes na sentença imperativa. Essa projeção é representada sintaticamente em uma configuração em que o núcleo Se c-comanda a projeção de modalidade $(M o d P)$.

A análise de Isac (2015) é crucialmente fundamentada na hipótese de haver diferença sintática entre o imperativo verdadeiro e o imperativo supletivo. No intuito de observar as principais contribuições de Isac (2015) para nossa proposta, apresentaremos a discussão a respeito das diferenças entre as sentenças imperativas com a forma verbal verdadeira e sentenças imperativas com a forma verbal supletiva, do ponto de vista da estruturação sintática que a autora propõe para esses dois tipos de sentenças e do ponto de vista da interação dos verbos imperativos com sujeitos abertos. 
3.5.2 A categoria SeP e os participantes da elocução imperativa

Para representar o imperativo, Isac (2015) adota uma proposta que combina propostas prévias, que a autora sistematiza na discussão (Speas; Tenny, 2003; Rupp 2003; Schwager 2005 e Zanuttini 2008). Em particular, assume tal qual Zanuttini 2008 que existe uma projeção com um núcleo funcional que contém traços de $2^{\mathrm{a}}$ pessoa e que esse núcleo entra em concordância com o sujeito apenas na ausência de traços phi na flexão verbal. Assim, quando o verbo é flexionado, o núcleo T, por hipótese é dotado de traços phi, e entra em concordância com o sujeito. Dessa forma, Isac (2015) também assume que o destinatário é representado na sintaxe imperativa, independentemente de a sentença ser realizada com a forma verdadeira ou com a forma supletiva de imperativo. Para Isac, o destinatário é concatenado no especificador (Spec) da projeção Speech Event $(\mathrm{SeP})$ e entra em concordância com o núcleo Se e seus traços phi.

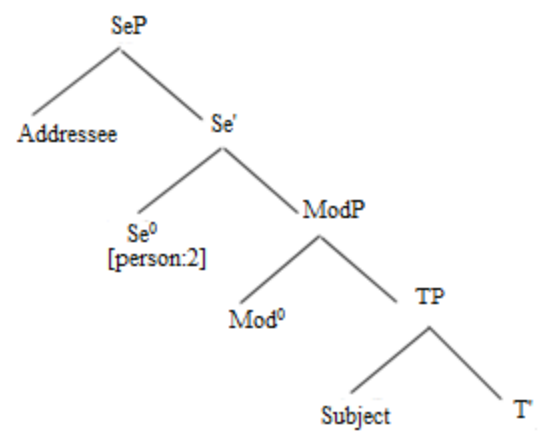

(ISAC 2015:97)

Isac (2015) adota, portanto, a categoria Speech Event em vez de utilizar a projeção jussiva de Zanuttini em razão de que, para ela, a projeção SeP dá conta não apenas da orientação do imperativo para o destinatário, mas também do ancoramento temporal ao evento discursivo. Além disso, a autora afirma que a projeção jussiva é sempre orientada para a segunda pessoa e que SeP, além de comportar os traços de segunda pessoa, abrange outros traços de pessoa.

Dessa forma, Isac (2015) assume que a projeção SeP está presente em todos os tipos de sentenças e que os traços presentes em seu núcleo diferem de acordo com o tipo de destinatário e o tipo de emissor que formam o estado de conhecimento. A autora 
chama atenção para o fato de que, ao dizer que o núcleo SeP tem um traço de segunda pessoa inerente, será necessário diferenciar sentenças imperativas de declarativas. A distinção proposta por ela fundamenta-se na hipótese de que as sentenças imperativas possuem um componente causativo e que as declarativas não possuem esse componente.

Speech event has the speaker as the causer but the actor responsible for carrying out the caused event is the addressee.

(ISAC 2015: 98)

A presença do traço [causa] em Se nas sentenças imperativas é justificada na análise de Quer (1998), citado pela autora, sobre 'seleção de modo', com base na observação de que, em muitas línguas, se um verbo causativo aceita sentenças finitas, o complemento do verbo causativo estará no subjuntivo. Considerando-se que o evento causado representa uma situação futura distinta em comparação com a situação inicial, explica-se o porquê de verbos causativos poderem tomar orações finitas que utilizam o subjuntivo. Tal situação é ilustrada em (28), com dado fornecido pela autora (do romeno).

(27) A face pe cineva as faca ceva INF.PRT make ACC. Somebody SBJ.PRT do.SUBJ.3SG something INF.PRT fazer ACC.alguém SBJ.PRT fazer.SUBJ.3sg algo 'to make somebody do something'/ 'fazer que alguém faça algo'.

(ISAC 2015:99)

Seguindo com a argumentação de Quer (1998), a autora assume que a estrutura semântica do enunciado inclui um operador de CAUSA, que intermedia a relação entre o verbo causativo e seu complemento. Dessa maneira, verbos causativos não selecionariam diretamente seus complementos, mas seriam ligados a um VP cujo núcleo é formado por um predicado de CAUSA, o qual, por sua vez, seleciona o complemento subjuntivo. O verbo causativo é, portanto, responsável apenas por denotar o modo da causação. Estendendo essa análise aos enunciados imperativos, Isac (2015) postula que a presença de um componente causal nas imperativas permite construir para uma sentença como (28a), com a interpretação em (28b)

(28) a. Brush your teeth!

'Escova o dente!' 
b. The speaker causes it that the addressee brings it about that his/her teeth are brushed by uttering (a).

O falante causa que o destinatário faça com que seus dentes fiquem escovados ao enunciar (a).

(ISAC 2015:99)

Há nesse contexto dois componentes causais: o primeiro envolve o ato de elocução em que o emissor causa no destinatário a ação de fazer algo por meio da elocução imperativa e um outro componente que envolve a realização do comando pelo destinatário a fazer algo acontecer. Essa separação é crucial na análise de Isac (2015), sendo determinada pela presença do traço [CAUSA] na projeção funcional SeP da oração imperativa, a qual, por sua vez, manifesta traço de $2^{\mathrm{a}}$ pessoa. Dessa forma, conclui a autora: "Not all Speech Event have a 2nd person feature, only those Speech Event heads that have a [cause] feature to do so.” (p. 100)

\subsubsection{A configuração do imperativo verdadeiro}

A análise das sentenças imperativas com a forma verdadeira proposta por Isac (2015) é baseada na identificação de traços. Para a autora, o traço de Mod é um afixo de PF que precisa ser adjacente ao verbo. Os verbos imperativos com a forma verdadeira realizam movimento para o núcleo da categoria Mod. A estrutura também manifesta TP, mas a autora considera que o núcleo $\mathrm{T}$ nas sentenças imperativas verdadeiras é não finito. Isso significa que o núcleo $\mathrm{T}$ em imperativas verdadeiras não apresenta traços phi. Essa análise traz como consequência o fato de que o único tipo de sujeito que pode ocorrer gramaticalmente em sentenças com a forma verdadeira é o sujeito sem traço de pessoa valorado, que pode ser valorado apenas como segunda pessoa em concordância com o núcleo Mod, que é inerentemente marcado para segunda pessoa.

A natureza defectiva de $\mathrm{T}$, em relação aos traços phi, a autora atribui à ausência de traços phi no núcleo Mod (equivalente a C) das sentenças imperativas. Essa relação sustenta-se na proposta de que $\mathrm{T}$ sempre herda os traços phi e de Caso de C, conforme Chomsky $(2007,2008)$. A autora argumenta que a presença de TP se justifica em função da ocorrência de sintagmas adverbiais temporais que ancoram os predicados em orações 
imperativas a um intervalo de tempo, conforme ilustrado a seguir, com um dado de Kaufmann (2011), citado pela autora (p. 102):

(29) Sună-mă marțea viitoare! (ancoragem externa)

Call IMP.2sg.-CL.1sg Tuesday next/ Chamar $_{\text {IMP.2sg.-CL.1sg terça-feira próxima }}$

'Call me next Tuesday!'/ 'Me chame na próxima terça-feira!'

Assim, por serem de domínio não finito, sentenças imperativas com a forma verdadeira sempre terão sujeitos idênticos aos destinatários. Dessa forma, todos os casos em que houver discrepância entre o Destinatário e o sujeito não serão realizados com verbos com a forma verdadeira. As sentenças com a forma supletiva, por outro lado, podem ser realizadas com verbos que acionem destinatários diferentes da segunda pessoa.

A autora passa a analisar as sentenças com imperativo verdadeiro, distinguindo os da classe I, que não admitem serem negados (e exigem o clítico pós-verbal), e os da classe II, que não apresentam restrição à negação (e à sintaxe do clítico). Após excluir a hipótese de analisar traço Mod de imperativos da classe I como afixos em PF, proposta em estudos prévios, Isac (2015) passa a defender uma análise baseada no movimento do verbo (o que, a nosso ver, resgata a proposta original de Rivero (1994), conforme apresentada no Capítulo 1).

Isac (2015) parte dos dados e da análise de Zanuttini (2008) (cf. seção 3.4), em que são considerados os seguintes tipos de sujeito (da oração imperativa): (i) DPs não pronominais definidos, com traço de $3^{\text {a }}$ pessoa valorado inerentemente; (ii) DPs não pronominais com D nulo: nomes nus, sintagmas quantificadores, nomes próprios, com traço de pessoa interpretável não valorado; (iii) sujeitos pronominais lexicalmente realizados, inerentemente marcados para $1^{\mathrm{a}}, 2^{\mathrm{a}}$ e $3^{\mathrm{a}}$ pessoa (ou seja, seu traço de pessoa é interpretável e valorado); (iv) sujeitos pronominais nulos. (p. 110)

Na hipótese da ocorrência de um DP definido não pronominal com traço de terceira pessoa inerente em uma sentença imperativa verdadeira, a análise prevê que a derivação não vai convergir. Segundo Isac (2015), a explicação para a não convergência está no fato de que o traço de Caso de um sujeito DP somente poderá ter traços valorados em contraste com o traço de Caso do núcleo Se. No entanto, esse núcleo em sentenças imperativas com a forma verdadeira sempre exibirá um traço de segunda pessoa. Como o traço de Caso do sujeito não pode ser valorado com T, pelo fato de que $\mathrm{T}$ nas sentenças com a forma verdadeira não tem traços phi (admitindo-se que passe a 
tê-los por herança de Mod/SeP), não ocorrerá a convergência da derivação (cf. 29). É o que está ilustrado no dado (30).

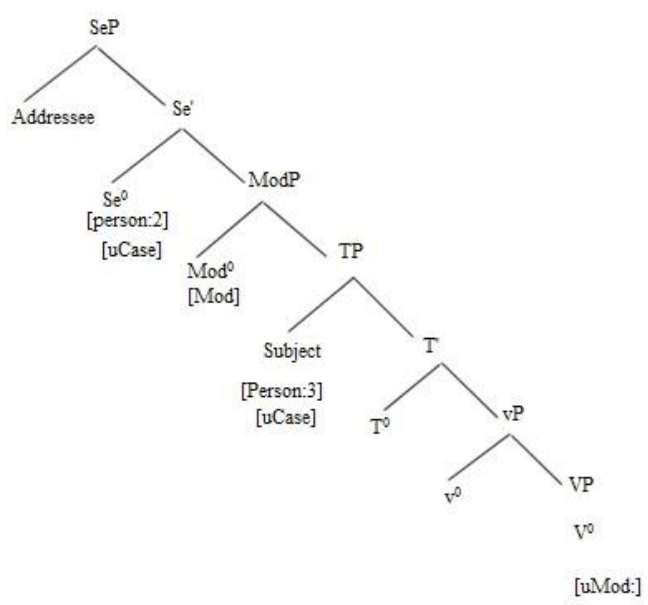

(ISAC 2015:110)

(31) *(Fata) du-te (fata) acasa! (Romanian/Romeno)

(girl.the) take.IMP.2SG-yourself.CL (girl.the) home

(moça.a) leve.IMP.2SG-SE.CL (moça.a) casa

'Go home girl!'/ 'Moça vá para casa!'

(ISAC 2015:111)

Seguindo a argumentação de Isac (2015: 111), se um DP não pronominal com um D nulo é concatenado como sujeito de uma sentença com a forma imperativa verdadeira, seu traço de pessoa interpretável (não valorado) será valorado por concordância com o traço de segunda pessoa no núcleo Se. O traço de Caso desses sujeitos será valorado no mesmo núcleo Se. Necessariamente o traço de pessoa no núcleo Se e o traço de pessoa no sujeito corresponderão em termos de valor, já que estão em relação de concordância.

Se um pronome foneticamente realizado, inerentemente marcado como primeira, segunda ou terceira pessoa é concatenado como sujeito em uma sentença com a forma verbal do imperativo verdadeiro, o resultado somente será gramatical se o pronome tiver o traço de segunda pessoa. Isto se dá porque é a única situação em que o traço de pessoa 
do sujeito pode se associar ao traço do núcleo levando assim à eliminação do traço de Caso no sujeito, conforme ilustrado em (32), com dados de Isac (2015: 111).

(32) a.(Tu) du-te (tu) în câmera ta! (Romeno)

(you) take.IMP.2SG-yourself (you) in room.DEF your

'You go to you room!'/Você vai para o seu quarto!'

b.*(El) du-se (el) în camera lui!

(he) take.IMP.2SG-himself (he) in room.DEF his

'Make him go to his room!'/'Faça ele ir para o seu quarto!'

c.*(Eu) du-ma (eu) în câmera mea!

(I) take.IMP.2SG-myself (I) in room.DEF

my

'Make me go to my room'. Me faça ir para o meu quarto.

(ISAC 2015:111)

Quanto às sentenças imperativas em que o sujeito é nulo, a única opção é validálo como $2^{\mathrm{a}}$ pessoa, tendo como referência a hipótese originalmente formulada em Chomsky (1982) e Rizzi (1986), citados pela autora, de que devem ser identificados por traços phi de um núcleo funcional (Infl, no caso de orações finitas). Assumindo-se, nos termos da autora, que a presença do traço de Caso não interpretável no DP pronominal o torna ativo para a operação Agree, seu traço de pessoa será validado na relação com o núcleo da projeção Mod, marcado para o traço de $2^{\mathrm{a}}$ pessoa (por herança de $\mathrm{Se}$ ),

Nesse sentido, os únicos tipos de sujeito que gramaticalmente podem ocorrer em sentenças com imperativo verdadeiro são aqueles que possuem o traço de pessoa não valorado, que pode ser valorado exclusivamente como segunda pessoa em concordância com o núcleo Mod, e aqueles que são inerentemente marcados para segunda pessoa, compatíveis para concordar com Mod ou Se coincidentemente. Assim, Isac assume que o sujeito de sentenças imperativas verdadeiras é sempre idêntico ao Destinatário. Todos os casos em que há divergência entre destinatário e sujeito não serão categorizados como imperativos verdadeiros, mas como imperativos supletivos.

A explicação para impossibilidade de negar o imperativo verdadeiro apoia-se na hipótese de que a negação é marcada para o traço de modalidade, conforme proposto em estudos prévios (cf. Giannakidou 1997, citado por Isac (2015). Nesse sentido, segundo a autora, 
the Mod head that has a matching feature than the imperative verb (...) the [Mod] feature on the Mod head cannot "reach" further than the most local march, which in our case is Neg. (p. 116) ${ }^{38}$

Em relação às línguas Classe II, que admitem que o imperativo verdadeiro seja negado, a autora propõe que a diferença em relação às línguas da Classe I se deve a dois fatores: (i) o estatuto sintático da negação (núcleo X ou sintagma XP) (nos termos de Zanuttini (1991), citado pela autora), e os traços morfossintáticos do marcador de negação (afixal ou não afixal). Línguas da classe II usam um marcador neg do tipo XP dessa forma o verbo se move para o núcleo nulo Neg, que nessas línguas, é afixal, e depois o complexo [V+Neg] se move para o núcleo Mod. A opção de um marcador de negação do tipo X está também disponível para línguas da Classe I, embora Neg nessas línguas não seja afixal, o que impede a formação do complexo [V+Neg], excluindo-se a possibilidade do movimento para Mod, em PF.

\subsubsection{A configuração do imperativo supletivo}

Em relação ao imperativo supletivo, Isac (2015) desenvolve a análise apontando semelhanças e diferenças em relação ao imperativo verdadeiro, o que permite retomar as propriedades postuladas até o momento, em relação à modalidade e ao envolvimento do destinatário/ $2^{\mathrm{a}}$ pessoa, bem como o envolvimento do falante.

Adotando perspectiva translinguística, a autora parte da observação de que os verbos no subjuntivo são utilizados em vários contextos. Em contextos matrizes, os verbos no subjuntivo podem ocorrer em sentenças optativas e diretivas, conforme ilustrado com dados da autora.

Optativas
a.(Che) Dio ci aiuti!
(Italiano)
(That) God us help.SUBJ.3SG
'God help us'/ 'Que Deus nos ajude!'

b.(Que) Dieu nous aide!

(Francês)

\footnotetext{
38 “(...) a impossibilidade de negar imperativos decorre nesta análise do fato de que a negação manifesta traços de Modalidade e NegP está mais perto do núcleo Mod que tem o traço compatível do que o verbo no imperativo (...) o traço [Mod] no núcleo Mod não consegue "alcançar" uma posição mais distante, que no nosso caso é Neg." [tradução nossa]
} 
(That) God us help.SUBJ.3SG us

'God help us!' / 'Que Deus nos ajude!'

c.Gott hilfe uns!

(Alemão)

Gos help.SUBJ.3SG us

'God help us!' / 'Que Deus nos ajude!'

d.God help us!

God help.SUBJ.3SG us!

(Inglês)

'God help us!' / 'Que Deus nos ajude!'

Diretivas

a.(Che) Mario parta!

(Italiano)

(That) Mario leave.SUBJ.3SG

'Let Mario leave!' / 'Deixe Mario sair!'

\author{
b.Gehe Paul weg! \\ Go.SUBJ.3SG Paul away \\ 'Let Paul go!' / 'Deixe Paulo ir!' \\ (Alemão)
}

(ISAC 2015:153)

Em contextos de encaixamento, o subjuntivo é, geralmente, utilizado após verbos volitivos, conforme ilustrado a seguir (com dados da autora).

(34) a. Paolo vuole che tu venga.

(Italiano)

Paolo wants that you come SUBJ.2SG

'Paul wants you to come.' / 'Paulo quer que você venha.'

b. Paul veut que tu viennes

(Francês)

Paul wants that you come.SUBJ.2SG

'Paul wants you to come.' / 'Paulo quer que você venha.'

c. Ich wollte, du warest hier.

(Alemão)

I wanted you wereSUBJ.2SG here.

'I wanted you were here'/'Eu queria que você estivesse aqui.'

d. Jon vill ad Maria fari

Jon wants that Maria leave.SUBJ.3SG

(Islandês)

'Jon wants that Maria'/ 'Jon quer que Maria saia.'

(ISAC 2015:154)

Isac (2015) observa que a diferenciação entre o indicativo e o subjuntivo é tradicionalmente realizada por meio da distinção realis (modo da asserção) e irrealis (modo da não asserção), respectivamente. Reconhecendo a simplicidade dessa distinção, a autora ressalta que seu objetivo não é exatamente aprofundar a análise desse contraste, 
retendo apenas a ideia de que o subjuntivo carrega um elemento modal nos contextos encaixados, a ser entendido nos termos de Kratzer $(1981,1991)$, citada pela autora:

the subjunctive expresses a relation between a context (roughly provided by the main clause) and the proposition expressed by the embedded clause. (p. $155)^{39}$

Assim, conforme Isac (2015), nos exemplos em (34a), a proposição expressa pela oração encaixada é avaliada com relação ao conjunto de 'desejos' do sujeito da oração matriz. A mesma análise pode ser estendida a orações em que o verbo subjuntivo ocorre na oração matriz, particularmente em relação ao subjuntivo utilizado como imperativo na forma supletiva.

(35) Che Mario vada!

(Italiano)

That Mario go.SUBJ.3SG

'Let Mario go!'

'Deixe Mario ir!'

(ISAC 2015: 155)

A análise segue argumentando que imperativos com verbos no subjuntivo (doravante imperativos subjuntivos), como imperativos verdadeiros, são também orientados para o falante. O falante é a fonte da obrigação/ permissão no imperativo supletivo. Essa afirmação é comprovada pelo contraste entre enunciados imperativos e deônticos: enquanto o primeiro exige que o falante seja a fonte da obrigação, o segundo admite que a fonte da obrigação não seja o enunciador, conforme indicam os dados a seguir, extraídos de Isac (2015: 64-65).

(36) a. Open the window! I insist on it!

'Abra a janela! Eu insisto!'

b. \#Open the window! Everyone but me insists on it!

'Abra a janela! Todos menos eu insistem nisso!'

(37) a. You must open the window. I insist on it.

'Você precisa abrir a janela. Eu insisto.'

b. You must open the window. Everyone but me insists on it.

'Você precisa abrir a janela! Todos menos eu insistem nisso!'

39 “(...) o subjuntivo expressa a relação entre o contexto (grosso modo fornecido pela oração matriz) e a proposição expressa pela oração encaixada." [tradução nossa] 
Outra evidência, segundo Isac (2015), é que o emissor nas imperativas com verbos no subjuntivo deve crer que a situação descrita pelo verbo imperativo é realizável.

A autora menciona ainda que existem línguas em que são usadas diferentes partículas dependendo de a ordem ser dada na perspectiva do falante ou do ouvinte - é o caso do Badiotto (língua reto-românica), que usa a partícula ma se o comando beneficia o destinatário, e não pode ser usada se o beneficiário é o falante, enquanto a partícula mo é usada nos contextos em que ma não pode ser usado. Isac (2015) observa que tais partículas, estando em distribuição complementar, não podem ser atribuídas às posições sintáticas que codificam o emissor e o destinatário. Dessa forma, descritivamente, são evidência para justificar a presença do ponto de vista do falante e do destinatário, mas sua distribuição sugere que sejam associadas a uma projeção de modo ou uma projeção do tipo evidencial (conforme sugere o estudo de Poletto e Zanuttini (2003), citado pela autora).

O envolvimento do destinatário é também uma propriedade das sentenças imperativas com formas verbais supletivas. Conforme demonstrado anteriormente, o sujeito em imperativos verdadeiros é sempre uma $2^{\mathrm{a}}$ pessoa, e portanto, sempre idêntico ao destinatário. Imperativos subjuntivos também o são, mas admitem que o sujeito não seja de $2^{\mathrm{a}}$ pessoa. Ou seja, nas imperativas verdadeiras o sujeito sempre é idêntico ao destinatário, nas imperativas supletivas o sujeito pode ter outros tipos de sujeito além da segunda pessoa. A autora exemplifica com o dado em (38) (p. 157):

(Romeno)

Petre să tacă din gură (că nu stie despre)

Petre SBJ.PRT shut-up.3SG of mouth (that not know.PRES.3SG about ce e vorba)!

'Petre should keep his mouth shut (because he doesn't know what he's talking about)!'

'Petre deveria manter sua boca fechada (porque ele não sabe sobre o que está falando)!'

(ISAC 2015:157)

No exemplo, o sujeito e o destinatário são distintos ('Petre' não é um membro do conjunto da lista de destinatários), mas o destinatário é o responsável por garantir que outra pessoa (o sujeito) desempenhe o evento descrito na sentença. 
Isac (2015) conclui que os imperativos supletivos apresentam as mesmas propriedades que os imperativos verdadeiros: são modais, orientados ao falante e orientados ao destinatário. Uma diferença relevante, porém, é que, enquanto nas imperativas verdadeiras o sujeito é sempre o destinatário, nas imperativas supletivas o sujeito e o destinatário não necessariamente precisam ser idênticos, mas quando ocorre o sujeito de $3^{\mathrm{a}}$ pessoa, a obrigação de preencher a ordem é colocada no destinatário, em vez de no sujeito.

Retomando a argumentação de Hacquard (2006), citada pela autora (cf. também Capítulo 2), que identifica imperativos e modais (epistêmicos e deônticos) verdadeiros, em oposição aos modais de raiz (no que se refere à orientação para o falante e para o destinatário, à ausência de denotação, à ausência de acarretamentos de atualização na realidade, ao ancoramento temporal no evento de fala), Isac (2015) propõe que imperativos verdadeiros e imperativos subjuntivos ocupam posição alta na estrutura (exatamente como os modais verdadeiros em oposição a modais de raiz, na proposta de Hacquard).

Com essa descrição, Isac (2015) passa a definir a constituição dos núcleos na estrutura da sentença imperativa com o verbo no subjuntivo. Inicialmente, propõe que o núcleo Se carrega traços de pessoa e de caso.

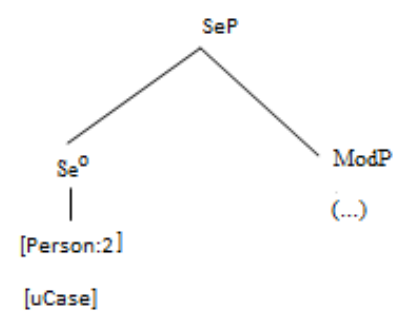

(ISAC 2015:160)

Para a autora, as diferenças entre imperativas verdadeiras e imperativas supletivas podem ser definidas em termos de que o núcleo Mod tem traços diferentes na composição de imperativas supletivas. Enquanto o núcleo de imperativas verdadeiras é não-finito, o de imperativas supletivas é finito. Retomando Chomsky (2008), Isac assume que o Mod finito tem traços phi não interpretáveis e traços de caso, e que Mod transmite esses traços para o núcleo funcional que seleciona - uma análise que pode ser 
comparada à de Zanuttini (2008). Além disso, assume que Mod carrega um traço EPP em imperativas supletivas, tal como as imperativas verdadeiras.

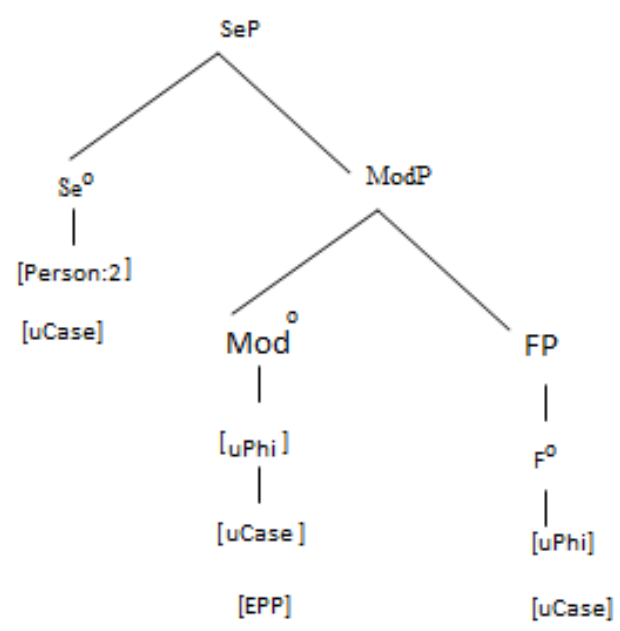

(ISAC 2015:161)

Ambas as imperativas, verdadeiras e subjuntivas, têm um núcleo Mod com traços EPP, mas o núcleo Mod das subjuntivas é finito e, dessa forma seus traços phi e de caso são transmitidos para o núcleo funcional $\mathrm{F}$ selecionado por Mod. Para Isac (2015), a principal consequência dada pela diferença entre as estruturas imperativas com a forma verdadeira e com a forma supletiva está na valoração dos traços de pessoa dos sujeitos.

"Subjects of subjunctive imperatives end up with two possible
sources for checking their person and Case features: either the
Se head, or F head that inherits such features from Mod. In
contrast, subjects of true imperatives can only check their
person and Case feature against the Se head."

(ISAC 2015:161)

Isac (2015) assume que posicionar um traço EPP em Mod garante que o núcleo de Mod sempre atraia um núcleo c-comandado e, assim, que Mod seja sempre preenchido. A autora apresenta os itens que podem ocorrer em Mod em sentenças imperativas subjuntivas. São elas: as partículas subjuntivas de línguas como o grego e o romeno, em que ocorre uma divisão de trabalho, já que a partícula realiza Mod, e o verbo carrega outros traços flexionais e traços phi, e os verbos flexionados no

40 "Sujeitos de imperativos subjuntivos têm duas formas possíveis de verificar seus traços de pessoa e Caso: seja o núcleo Se ou o núcleo F que herda tais traços de Mod. Em contraste, sujeitos de imperativos verdadeiros podem somente verificar seus traços de pessoa e Caso em relação ao núcleo Se.” [tradução nossa] 
subjuntivo, em línguas como o alemão, em que não há essa divisão, pois não há evidência da existência de partícula, mas o verbo é marcado para a categoria de modo.

Para a presente análise, interessa a discussão em torno das estruturas imperativas do francês e do espanhol (com equivalentes em português) introduzidas por que, ilustradas a seguir com dados do espanhol, adaptados de Isac (2015: 169), em que se constata a obrigatoriedade de que:

(41) *(Que) lo escribáis!

That it write.suBj.2pl/ que $\mathrm{CL}_{3 \mathrm{~s}}$ escrevais

'You just write it!'/ 'Que escrevam isto!'

Diferentemente das partículas do romeno e do grego, que não precisam estar adjacentes ao verbo (ou a clíticos e à negação), o que descarta uma análise como um clítico, a partícula que se concatena no especificador de uma projeção hospedeira de clíticos (FP) - conforme proposto para as partículas subjuntivas dessas línguas. Assim, a autora propõe que a partícula que em dados como (41) se concatena como núcleo diretamente em Mod. Além disso, postula que, como introdutora de imperativos subjuntivos, a partícula que não tem as mesmas propriedades de que introdutor de orações encaixadas, sendo esta última concatenada como núcleo de CP. No entanto, segundo a autora, o fato de serem parafraseáveis como "I (the speaker) told you (the addressee) that $\mathrm{p}$ (the que subjunctive)" (p. 170) ${ }^{41}$ é motivo assumir que tenham estatuto de oração encaixada e que sejam analisadas como um $\mathrm{CP}$ que não contém $S e \mathrm{P}$ (sendo SeP postulado apenas para orações principais), manifestando traços phi/Caso, que serão transmitidos a Mod.

$\mathrm{Na}$ análise do sujeito dos imperativos subjuntivos, Isac (2015) retoma o contraste com os imperativos verdadeiros, em relação à possibilidade de que sejam realizados pelas três pessoas, observando que isso exclui a análise em que SeP inclui o traço interpretável de $2^{\mathrm{a}}$ pessoa o núcleo a ser validado pelo sujeito (conforme proposto para os imperativos verdadeiros).

Considerando que a tipologia de sujeitos é a mesma observada para imperativos verdadeiros, Isac (2015) leva em conta cada uma das possibilidades: (i) sujeito com um traço interpretável de pessoa intrínsecamente valorado (DPs definidos e pronomes abertos); (ii) sujeitos com um traço interpretável de pessoa, mas não valorado (Nomes Nus, nomes próprios, sujeitos quantificacionais) e (iii) pronomes nulos. Em

\footnotetext{
41 “Eu (o falante) disse a você (o destinatário) que $p$ (a oração subjuntiva de que)." [tradução nossa]
} 
casos em que um DP contém um traço de pessoa intrinsecamente valorado, o traço não interpretável de pessoa em F entra em concordância (Agree) com o DP sujeito, sendo eliminado, assim como o traço de Caso do DP sujeito.

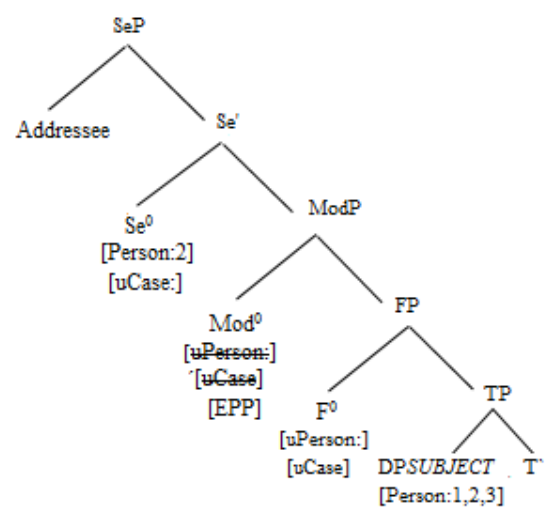

(ISAC 2015:172)

O exemplo (43) demonstra cada tipo de sujeito que é inerentemente marcado para pessoa: em (43a) um pronome de segunda pessoa aberto, em (43b) um pronome de terceira pessoa, em (43c) um DP definido e em (43d) um pronome de primeira pessoa.

(43) a.Tu să stai lânga usă!

(Romeno)

you SUBJ.PRT stay.SUBJ.2SG near door

'You stay by the door!' / 'Que você fique perto da porta!'

b.El să stea lânga usă!

He SUBJ.PRT stay.SUBJ.3SG near door

'Have him stay by the door!' / 'Que ele fique perto da porta!'

c.Cătelul să stea lânga usă!

Dog.the SUBJ.PRT stay.SUBJ.3SG near door

'Have the dog stay by the door' /'Que o cachorro fique perto da porta!'

d.?Eu să stau lânga usă!

I SUBJ.PRT stay.SUBJ.1SG near door

Have me stay by the door! / 'Que eu fique perto da porta!'

(ISAC 2015:172)

Isac (2015) observa que os pronomes de primeira pessoa podem ser gramaticais como sujeitos de imperativas subjuntivas, em razão de que a interpretação de sentenças imperativas sempre envolve um destinatário que observa que a ação descrita na sentença seja realizada pelo sujeito e é difícil obter uma interpretação em 
que o falante (que normalmente é o controlador de suas próprias ações) convide ao destinatário para causar alguma ação que afete o próprio falante.

Na discussão dessa questão, Isac (2015) retoma a proposta de que as sentenças imperativas são duplamente causativas: existe um traço causal no ato de elocução - o falante faz com que o destinatário realize algum evento pela elocução imperativa; adicionalmente, existe um segundo componente causal que consiste na execução do comando pelo destinatário. Dessa forma, o falante é o agente do evento discursivo enquanto o destinatário é o agente do evento encaixado. Existem, portanto, três eventos envolvidos, conforme descrito em (44): o evento de fala (Se); o evento que tem o destinatário como agente (Ae); e o evento descrito pelo verbo, o evento do sujeito (SBe) - SBe pode ser um agente ou o sujeito de um estado. Diante dessa cadeia de relações transitivas, o sujeito, além de ser Agente, pode ser interpretado como Tema/Paciente.

Componentes causais em imperativos

[se I (speaker) causes [Ae you (addressee) to cause [sBe the subject to do something]]]

(ISAC 2015:173)

Dada a ligação entre os dois eventos causados, o falante é indiretamente de uma maneira parcial o causador do evento e pode ser interpretado como, ao mesmo tempo, o causador indireto e o causador direto do evento (é o que denota (43d). Isac (2015) acrescenta que se o sujeito da sentença é o falante, mas o sujeito não for interpretado como Agente do respectivo evento, o resultado é aceitável na $1^{\mathrm{a}}$ pessoa, conforme os dados (45a-b), extraídos de Isac (2015: 173).

(45) a.Eu să fiu asezat lânga usa

(Romeno)

I SBJ.PRT be.SUBJ1SG placed near door

'Place me by the door!/ See to it that I'm placed by the door!'

b. Eu să cad in picioare!

I SBJ.PRT fall.SUBJ1SG in feel

'Make me fall on my feet'

(ISAC 2015:173)

Sujeitos que carregam inerentemente traços de $\left(3^{\mathrm{a}}\right)$ pessoa valorados são gramaticais não apenas em línguas que usam partículas subjuntivas clíticas foneticamente realizadas (como o grego e o romeno), mas também em línguas como o inglês, que, por hipótese, possui partículas subjuntivas cobertas (nos termos da análise 
de Zanuttini 2008), ou como o alemão, que não possui essas partículas e o verbo manifesta traços de modo. Os dados relevantes aduzidos por Isac (2015: 174) estão citados a seguir:

a. The boys stand by the door!

(Inglês)

'Os garotos ficam perto da porta!'

b. Schreib Du den Aufsatz!

(Alemão)

Write.2SG.imp you the letter

'You write the letter!' /'Você escreve a carta!' (Han, 2000 ex 10)

c. Gehe Paul weg!

(Alemão)

Go.SUBJ Paul away

'Let Paul leave!'/ Deixe Paul ir!' (Giogi and Pianesi, 1997:195,

ex 3)

(ISAC 2015:174)

$\mathrm{Na}$ análise de Isac (2015), o fato de o núcleo funcional $\mathrm{F}$, em imperativas subjuntivas, ter um traço de pessoa diferencia esse tipo de sentença das imperativas verdadeiras, em que o SeP aloja um traço interpretável de $\left(2^{a}\right)$ pessoa não valorado. A autora defende que é essa propriedade que explica por que imperativas subjuntivas permitem sujeitos de terceira pessoa, em oposição às imperativas verdadeiras, que apenas permitem sujeitos de segunda pessoa (no singular ou no plural). Como os traços de pessoa em F não são inerentemente valorados, são compatíveis com qualquer valor para o traço de pessoa na posição de sujeito. Esse contraste é ilustrado em (47) pela autora com o par mínimo extraído do romeno:

(47) a.*Fetele plecati de aici!

(Romeno)

girls.the leave.IMP.2PL from here

'The girls leave!'/ As meninas saem!'

b. Fetele sa plece de aici!

Girls.the SBJ.PRT leave.SBJ.3PL from here

'The girls should leave!' /'As meninas deveriam sair!'

(ISAC 2015:174)

Sujeitos com traços de pessoa interpretáveis e não valorados - expressões quantificacionais, nomes próprios, e nomes nus - em sentenças imperativas subjuntivas podem ter seu traço de pessoa valorado como $2^{\mathrm{a}}$ ou $3^{\mathrm{a}}$ pessoa. ${ }^{42}$ Segundo Isac (2015), a

\footnotetext{
${ }^{42}$ Os casos de imperativos com sujeitos quantificacionais/ nomes próprios/ e nomes nus que ligam
} pronomes de $3^{\text {a }}$ pessoa em inglês são analisados por Zanuttini (2008), sob o argumento de que têm como 
valoração do traço de $2^{\mathrm{a}}$ pessoa é feita pelo traço interpretável de $2^{\mathrm{a}}$ pessoa (não valorado) em SeP. No entanto, o traço de $3^{a}$ pessoa requer outra explicação. A autora propõe que

(...) the variable introduced by these expressions can be bound by two different operators, one that adjoins to the FP projection and is associated with a default, $3^{\text {rd }}$ person feature, and one that adjoins to the SeP level, that is associated with a $2^{\text {nd }}$ person feature (p. 175) ${ }^{43}$.

A proposta de Isac (2015) toma como referência a contribuição do contexto, bem como a noção de ligação de variáveis de situação. Para tanto, assume com von Fyntel (1994) e Percus (2000) que expressões nominais são interpretadas em relação a uma situação (definida como um estado de coisas, com uma especificação espacialtemporal). Essa dependência do contexto é particularmente evidente quando se trata de verificar o conjunto definido pelos restritores de expressões quantificadas, que pode ser a intersecção com um conjunto de indivíduos contextualmente relevantes ou com o conjunto de destinatários, os quais correspondem, respectivamente, à terceira pessoa e à segunda pessoa. ${ }^{44}$

correlatos os imperativos subjuntivos, embora não manifestem as categorias morfossintáticas relevantes (cf. seção 3.4).

43 “(...) a variável introduzida por essas expressões pode ser ligada por dois operadores diferentes, um que se adjunge à projeção FP e é associada a um traço default de 3a pessoa, e uma que se adjunge ao nível de SeP, que é associado a um traço de $2^{\text {a }}$ pessoa." [tradução nossa]

44 Seguindo Percus (2000), que defende serem essas restrições implementadas como uma variável sintaticamente representada, que é ligada, Isac (2015) observa que há propostas em que a variável é introduzida pelo determinante quantificacional ou pelo nominal restritor. No entanto, propõe situar a variável em um determinante definido, segundo a proposta de que a restrição contextual do domínio de um quantificador é feita por um determinante não quantificacional, selecionado pelo quantificador (o que permite um tratamento unificado em relação a nomes próprios e nomes nus). Esses determinantes envolvem quantificação sobre indivíduos e situações. A autora propõe então que a dependência entre expressões quantificacionais e o contexto é expressa na sintaxe, tendo em vista que tem sua origem em um traço de pessoa, que é valorado na sintaxe. Enfocando variáveis introduzidas por verbos, e considerando que verbos não são quantificacionais, observa que a variável introduzida por verbos está sujeita ao fechamento existencial. Seguindo proposta de Heim; Kratzer (1998), citada pela autora, assume que, nessa relação de dependência, variáveis livres são ligadas por um operador lambda nulo na sintaxe. Considerado um equivalente do fechamento existencial, o operador lambda liga a variável e ao mesmo tempo muda o tipo do termo (type) na posição de complemento, convertendo a fórmula que contém as variáveis livres em predicados. Seguindo Parcus (2000), a autora propõe que, em imperativos subjuntivos, o operador lambda é adjungido a vP e move-se para TP, o que em sua análise refere-se à projeção FP. Variáveis de situação introduzidas por DP podem também ser ligadas existencialmente, mas não por um operador independente. A diferença entre a variável de situação dos verbos e a dos nomes é quanto à ligação de 's' [situação], se por um operador lambda ou não. Enquanto variáveis verbais de situação são ligadas localmente, variáveis de situação introduzidas por determinante definido não são restringidas por localidade, e serão co-indexadas com uma variável de situação introduzida por um verbo - seja um verbo local, seja um verbo na oração mais alta. Considerando que a análise das imperativas postula dois eventos (o evento denotado pelo vP e o evento de fala (Se)), Isac (2015) assume que cada um desses eventos é associado ao operador lambda. Crucialmente, o operador lambda valora traços de pessoa, mas não elimina 
Considerando que expressões quantificacionais, nomes próprios e nomes nus introduzem não só uma variável de indivíduo, mas também uma de situação (nos termos de Percus 2000, citado pela autora), Isac (2015) propõe que esta última pode ser ligada ao operador existencial adjungido tanto a TP (local) quanto a SeP, resultando que o DP ligado terá a interpretação default de $3^{\mathrm{a}}$ pessoa ou de $2^{\mathrm{a}}$ pessoa, respectivamente.

The two interpretations are thus due to the fact that the individual variable introduced by these expressions can be interpreted either relative to the situation that the sentence is about or relative to the speech situation. (ISAC 2015: 181)

Além do inglês, que admite estruturas imperativas com expressões quantificacionais, nomes próprios e nomes nus (com ligação de pronomes de $2^{\mathrm{a}}$ e $3^{\mathrm{a}}$ pessoa), a análise é estendida aos casos de imperativos subjuntivos de línguas que utilizam partículas subjuntivas (como o grego e o romeno) ou línguas em que o traço EPP de Mod é verificado pelo movimento do verbo, como o alemão e o islandês.

Segue-se a discussão acerca dos pronomes nulos como sujeitos. A autora retoma estudos prévios sobre a sintaxe de sujeitos nulos, observando com Holmberg (2005, 2010), citado pela autora, que, nos termos da teoria de valoração de traços de Chomsky (2001), os traços phi não interpretáveis de Infl são valorados pelos traços phi interpretáveis de pro. No entanto, a autora questiona, com base em Torrego e Pesetsky (2008), a relação biunívoca entre intepretabilidade e valoração de traços, investigando as possibilidades de lógicas em que os traços podem ter: (i) pro tem traços de pessoa interpretáveis e valorados; (ii) pro tem traços de pessoa não interpretáveis, porém valorados; (iii) pro tem traços de pessoa interpretáveis, porém não valorados; (iv) pro tem traços de pessoa não interpretáveis, e não valorados.

No primeiro caso, a conclusão é a mesma para sujeitos DPs inerentemente marcados para o traço de pessoa - os traços phi não interpretáveis de F serão verificados e eliminados, assim como o traço de Caso. Em (ii) e (iv), seria necessário acionar os traços interpretáveis de Se para verificar e valorar os traços não interpretáveis (não valorados) de pro, já que os traços de F, sendo não interpretáveis, não podem fazê-lo, o que implica que pro deve manifestar apenas a $2^{\mathrm{a}}$ pessoa, uma opção que não se sustenta nos dados, já que a $3^{\text {a }}$ pessoa ocorre em imperativos subjuntivos. A opção (iii) dispensa pro de verificação de seus traços pelo núcleo Se, deixando em aberto a opção de valorá-

os traços (de pessoa) não interpretáveis de F, o que requer a relação Agree com os traços interpretáveis do DP sujeito (cf. Isac 2015, p. 177) 
los - se a variável de situação introduzida por pro é ligada por operador lambda local (adjungido a IP), pro é valorado pela opção default como $3^{\mathrm{a}}$ pessoa, sendo os traços não interpretáveis de F verificados por pro mediante Agree, se pro é ligado pelo operador lambda vinculado a SeP, então o traço de pessoa em pro é valorado como $2^{\mathrm{a}}$ pessoa, e o traços phi não interpretáveis de F serão valorados mediante Agree - em ambas as opções, o traço não interpretável de Caso de pro é verificado por Agree com o núcleo F. As soluções (i) e (iv) sendo viáveis são retidas, para uma discussão que contemplará a questão da polaridade (a ser desenvolvida no Capítulo 4).

Ainda sobre a relação entre os tipos de sujeito e as sentenças imperativas, é relevante considerar um outro fator apontado por Isac (2015): o efeito de polidez. A autora observa que há uma diferença de polidez entre sentenças com a forma verdadeira e em subjuntivas raízes. Para Isac (2015), a maneira como o sujeito verifica os traços phi e de Caso afeta as sentenças imperativas. O destinatário nas sentenças imperativas verdadeiras é sempre idêntico ao sujeito, ou seja, nessas sentenças o sujeito é valorado inerentemente como de segunda pessoa e o traço de Caso vai ser identificado com Se e não com F. Por outro lado, nas sentenças imperativas formadas por meio de subjuntivas raízes, se o sujeito é inerentemente valorado como segunda pessoa, o traço de pessoa no núcleo F será valorado como segunda pessoa por concordância com o sujeito e F e, ao checar o traço, deleta o traço de Caso no sujeito.

Como nas subjuntivas o sujeito e o destinatário podem ser entidades distintas, nas sentenças subjuntivas com terceira pessoa, por exemplo, o destinatário pode ser convidado a fazer com que o sujeito realize a ação diretiva. O efeito de polidez ocorre então nas orações imperativas com a forma subjuntiva e a razão que Isac aponta para esse fato é que nessas orações o sujeito é sempre licenciado por F e não por Se, enquanto em imperativas verdadeiras o sujeito é sempre licenciado por Se. Por meio dessa caracterização, Isac propõe que as sentenças com a forma verdadeira e com a forma supletiva possuem diferenças de polidez, sendo a estrutura com a forma verbal do subjuntivo a forma mais polida.

\subsection{Considerações parciais}

A proposta de Isac é interessante para este trabalho, primeiramente, por propor uma diferença entre as sentenças imperativas com a forma verdadeira e supletiva por meio do contraste de traços: sentenças com a forma verdadeira são não finitas e 
verificam os traços diretamente no núcleo Se, enquanto sentenças supletivas verificam os traços em F, núcleo c-comandado por Mod. Nesse sentido, nos identificamos com essa proposta no sentido de que as sentenças do $\mathrm{PB}$, por não apresentarem a forma verdadeira, compõem o paradigma supletivo por meio de formas associadas ao subjuntivo e ao indicativo, haja vista a neutralização desses modos no PB. Além disso, o efeito de polidez pode ser vinculado aos fatores implicados na reanálise pronominal, que, como vimos, envolve a gramaticalização da forma de tratamento você, com implicações de ordem pragmática, com a neutralização da oposição entre pronomes de $2^{\mathrm{a}}$ pessoa e de $3^{\mathrm{a}}$ pessoa (cf. Capítulo 1 ).

Ao assumir a análise de Isac (2015) para as sentenças imperativas subjuntivas, identificamos essa proposta com a de Grosz (2011) e postulamos que as sentenças imperativas com o paradigma supletivo são optativas. Como consequência disso, nossa análise considera que as estruturas imperativas no PB também apresentam diferentes matizes de polidez, pelo fato de apresentarem um operador optativo no especificador de C, que marca a expressão do emissor no ato de elocução imperativo. Essa questão nos leva a supor que línguas que perderam a oposição sistemática entre imperativo verdadeiro e imperativo supletivo possuem um $\mathrm{C}$ especializado para o traço optativo, que capta a expressão do emissor, designando matizes modais distintas para a estrutura imperativa.

Além disso, Isac (2015) propõe uma estrutura que capta os participantes do ato de elocução. Conforme mencionado anteriormente, a relação dos componentes semânticos do ato de elocução imperativo é dada por meio de dois eventos causais diferentes: um relacionado ao emissor e um relacionado ao destinatário. Essa conclusão nos permite formular a hipótese, a ser desenvolvida e testada adiante, de que os participantes do ato de elocução são marcados em categorias diferentes, conforme o papel que desempenham nos eventos que realizam o enunciado imperativo. Assim, diferentemente de Isac (2015), propomos que o evento realizado pelo emissor é associado, na estrutura, ao operador EX, que marca a expressão do desejo do emissor na elocução imperativa. Nesse sentido, nas imperativas subjuntivas (supletivas), o núcleo SeP é substituído por uma projeção que inclui o operador EX, nos termos de Grosz (2011). Além disso, retemos a codificação do destinatário recorrendo à projeção jussiva proposta na análise de Zanuttini (2008). Nesse sentido, emissor e destinatário têm projeções dedicadas independentes, uma ideia disponível em análises prévias, com 
implicações diferentes, por abarcarem todos os enunciados, o que não está contemplado em nossa análise.

Esse contraste nos permite dar conta da hipótese de que o PB perdeu a configuração do imperativo verdadeiro, em razão da neutralização das propriedades a seguir: (i) reanálise do sistema pronominal; (ii) neutralização das formas do indicativo e do imperativo; (iii) variação entre as formas do indicativo e do subjuntivo, (iv) inovações em relação a sintaxe da negação e (v) inovações na sintaxe do sujeito em sentenças imperativas, conforme amplamente demonstrado em estudos prévios (cf. Capítulo 1). Com a manifestação articulada dessas propriedades, o PB perdeu tanto a morfologia quanto a sintaxe exclusiva da forma imperativa, o que desarticulou a gramática do imperativo verdadeiro. Vimos, anteriormente, que os resultados de Scherre (2007) e Scherre et al. (2007) conduziram para a conclusão de que o imperativo no PB passou a ser realizado apenas com a forma supletiva, recorrendo a formais verbais do indicativo e do subjuntivo.

Do ponto de vista da derivação sintática, a consequência dessa inovação é que, a partir do momento em que perdeu a forma verdadeira, o PB passou a ter apenas a derivação em que a projeção CP é marcada para o traço optativo, em que a primeira pessoa, na figura do emissor do ato de elocução, é introduzida pelo operador EX, o que corresponde ao primeiro evento de causa - o emissor causa uma ação ao estabelecer um comando - o qual é descrito no evento encaixado - a ser desempenhado pelo destinatário. O emissor na relação com o operador EX é responsável pela modalização do enunciado imperativo com diferentes matizes de significação (tal como Isac (2015) demonstra nas imperativas subjuntivas raízes). A análise inclui o núcleo Mod, que, diferentemente da forma verdadeira, possui traços phi e de Caso, os quais são verificados no núcleo $\mathrm{F}$, instanciado num nível mais baixo e que, na relação com o sintagma vP, denota o segundo evento, realizado pelo destinatário na elocução imperativa.

Essa estrutura dá suporte à nossa hipótese de que o ato de elocução das sentenças imperativas do PB é duplamente marcado: tanto para o emissor, por meio do operador expressivo, quanto para o destinatário, por meio do traço intrínseco de segunda pessoa em Mod (equivalente à projeção jussiva). Acreditamos que essa dupla marcação permite captar a hipótese de dupla causa existente nas sentenças imperativas, nos termos de Isac (2015), em que o emissor causa um evento ao atribuir um comando ao 
destinatário, e o destinatário é engajado na execução do comando dado pelo emissor. Detalharemos essa proposta na seção a seguir.

\subsection{Hipótese da configuração diretivo-optativa no PB}

\subsubsection{As propriedades da configuração optativa em C no PB}

O objetivo dessa seção é demonstrar, conforme estudos previamente desenvolvidos (cf. FERREIRA JUNIOR 2011; FERREIRA JUNIOR e SALLES 2015), que as sentenças imperativas no PB são enunciados optativos, que ocorrem em uma configuração em que o traço optativo, marcado por um operador expressivo (EX) é realizado no domínio de CP. Esse operador é responsável por avaliar o conteúdo expressivo da elocução expressa pela proposição introduzida na estrutura da projeção $\mathrm{CP}$, tendo em vista um desejo do emissor ( $\left(1^{\mathrm{a}}\right.$ pessoa do discurso $)$.

Recuperando a análise de Grosz (2011) (cf. Seção 3.3), podemos identificar que os enunciados optativos são caracterizados pela expressão do modo optativo independentemente da presença de itens lexicais, sendo realizado por meio da estrutura sintático-semântica da sentença. Por hipótese, esses enunciados contêm um operador semântico EX, dedicado a expressar a emoção presente na elocução. A emoção expressa no ato de elocução está diretamente relacionada à primeira pessoa, ou seja, ao emissor. Dessa maneira, é interessante notar que a leitura semântica do traço EX atribuída por Grosz (2011) às construções optativas se ajusta à interpretação que desejamos dar à leitura expressa estruturas imperativas no $\mathrm{PB}$, em que se verifica o uso variável de formas verbais associadas ao indicativo e ao subjuntivo. Dessa maneira, ambas as formas ocorrem em estruturas que envolvem um tipo de expectativa do emissor em relação a que se cumpra o que está sendo descrito, sendo essa expectativa matizada por efeitos de polidez, que se manifestam na relação com o sistema pronominal e com a sintaxe do sujeito - em que a realização nula alterna com a realização lexical, em posição pré-verbal (não marcada), em contraste com a posição pós-verbal (marcada).

Ainda adotaremos em nossa análise a perspectiva defendida por Zanuttini (2008) a respeito da presença do traço diretivo no ato de elocução imperativo. Zanuttini destaca que o CP em sentenças imperativas é marcado pelo traço diretivo, responsável por direcionar a força ilocucionária do imperativo para o destinatário. 
A expectativa gerada pelo evento causado pelo emissor na elocução imperativa é apresentada por Isac (2015), no sentido da proposta de que sentenças imperativas apresentam uma dupla relação de causa.

Nossa proposta agrupa as características das propostas de Grosz (2011), Zanuttini (2008) e Isac (2015) para oferecer uma compreensão inovadora a respeito da configuração imperativa no PB. Assim, seguindo o pressuposto do ato de elocução em duas instâncias, propomos que, nas sentenças imperativas no $\mathrm{PB}$, o primeiro evento de causa está diretamente associado à presença do operador optativo em $\mathrm{C}$, e representa a expectativa que o emissor tem ao realizar a proposição inicial do ato de elocução. $\mathrm{O}$ ato de elocução é marcado em (48) por uma relação de causa que representa a expectativa que o emissor cria ao realizar a proposição. Esse ato corresponde na estrutura a um desejo, que pode ser representado pela expressão 'quero que'.

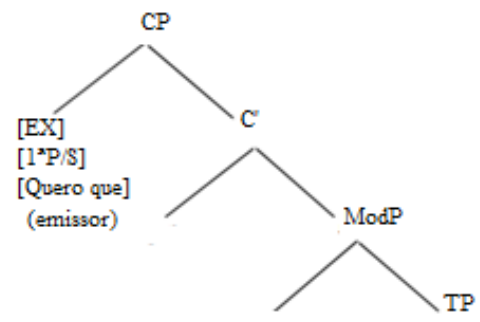

A realização desse operador nas sentenças imperativas do PB como correlato de uma expressão volitiva desiderativa implícita que licenciaria a modalidade optativa preserva a generalização quanto à distribuição sintática do modo subjuntivo (ainda que em variação com o modo indicativo). A importância de se preservar a generalização quanto ao papel do modo subjuntivo em nossa hipótese baseia-se no fato de que a formação do paradigma imperativo no PB mantém as formas supletivas do subjuntivo, em variação com as do indicativo.

A presença da morfologia do indicativo em variação com a de subjuntivo em construções imperativas do PB é explicada em termos da neutralização entre as formas do subjuntivo e do indicativo observada em orações completivas de verbos volitivos atestada no PB, e referida em vários estudos (cf. ROCHA 1997; SAMPAIO 2001; OLIVEIRA 2006; 2007). 
(49) a. Eu quero que você verifique o óleo e o nível da água da bateria da próxima vez.

b. Espero que algum dia o governo federal olha de uma maneira mais positiva pr'aqui $[\ldots]$

(dados de fala, extraídos de Rocha (1997))

Verificamos anteriormente que Isac (2015) apresenta sentenças raízes com formas verbais de subjuntivo em línguas como o espanhol como sentenças imperativas subjuntivas, conforme ilustrado em (43), repetido a seguir, como (50). Ainda, afirma que essas sentenças apresentam diferença de polidez com relação às sentenças imperativas com a forma verdadeira.

(50) *(Que) lo escribáis!

That it write.suBJ.2pl/ que $\mathrm{CL}_{3 \mathrm{~s}}$ escrevais

'You just write it!'/ 'Que escrevam isto!'

(ISAC 2015:169)

Assim como Isac (2015), consideramos que as sentenças imperativas com a forma supletiva possuem diferenças de polidez em relação às formas verdadeiras. Dessa maneira, línguas que possuem a distinção entre sentenças imperativas verdadeiras e supletivas apresentam as diferenças de matizes (polidez) por meio da diferença de checagem dos traços: imperativas verdadeiras checam os traços em C (para Isac, Speech event) e as sentenças com a forma supletiva realizam a checagem com a categoria funcional c-comandada por Mod (para Isac, F). No entanto, como em nossa hipótese o PB perdeu a forma verdadeira de imperativo, os matizes de polidez são apresentados de uma maneira diferente. Assumimos a presença do traço optativo em C, e do operador EX em adjunção a $\mathrm{CP}$, que capta o traço de primeira pessoa na expressão de um desejo do falante por meio do ato de elocução, o que oferece o contexto estrutural para a realização do sujeito pré-verbal com ambas as formas verbais.

Em nossa análise, o traço optativo não é analisado como uma categoria encaixada num verbo performativo. É um traço formal realizado no nível da forma lógica, e associado ao falante e ao operador EX, manifestando, por hipótese, correlatos sintáticos, diante da possibilidade de ligar uma variável introduzida por argumento interpretado como beneficiário, ou por partículas que denotam a existência ou não de um efeito pela execução do comando em relação ao falante. Dizer isso indica que as 
orações imperativas no PB não são realizadas por meio de encaixamento, mas, ao contrário, são sentenças raízes construídas com uma forma verbal associada ao subjuntivo em variação com a forma verbal associada ao indicativo. Além da constituição formal da categoria C (optativa), essas sentenças selecionam uma projeção que tem como núcleo a categoria Mod, que codifica a modalidade na estrutura oracional (a ser detalhada a seguir).

Dessa maneira, a categoria $\mathrm{C}$ das sentenças imperativas se distingue de $\mathrm{C}$ das declarativas e das interrogativas entre outros fatores por não corresponder a situações de encaixamento. Em nosso trabalho, a referência à expressão 'Quero que', como na estrutura em (48) é motivada apenas como ilustração do que representaria semanticamente o traço optativo nas estruturas imperativas no PB. Essa noção é captada na análise de Grosz (2011) das sentenças optativas na associação do traço optativo,

ligado à primeira pessoa do discurso, à expressão do desejo do emissor. Assim, os traços compartilhados pelo núcleo $\mathrm{C}$ por meio do operador $\mathrm{EX}$ possibilitam os diferentes matizes de modalidades presentes nas sentenças imperativas, os quais tentamos representar por meio dos exemplos em (51), a seguir.

a. Você abre/abra a porta (por favor)! (matiz brando)

b. Abre/Abra a porta (agora)! (matiz severo)

Nossa hipótese de trabalho é a de que esses matizes podem ser captados mesmo sem as expressões 'por favor' (51a) e 'agora' (51b), que contrastam os matizes de presença de polidez em oposição à ausência de polidez.

É relevante ressaltar que a possibilidade de captar os matizes citados está associada à presença do traço EX na estrutura, representando a expressão que o emissor deseja transmitir no ato de elocução. Nesse sentido, a proposição será selecionada pelo traço optativo, pelo qual é transmitida a um destinatário a existência de um desejo do falante, representado na estrutura em (40) pelo traço de $1^{\mathrm{a}}$ pessoa. Por hipótese, essa opção está disponível na GU, e permite introduzir, na configuração imperativa, um beneficiário/ maleficiário. Essa situação pode ser ilustrada com a língua Badiotto (língua reto-românica), referida por Isac (2015), que alterna o uso das partículas ma e mo, para codificar a relação entre o comando e o destinatário (cf. seção 3.5.4). Essa possibilidade pode ser expressa em línguas como o português por meio da categoria 
dativo (de interesse/ ético), introduzida na estrutura do VP, a qual será ligada pelo operador EX - o que se confirma (parcialmente) pela tendência a que essa categoria seja realizada pela primeira pessoa.

(52) Não me abre a porta! / Abre a porta pra mim!

Essa análise exclui, portanto, a projeção SeP, que codifica o evento de fala, nos termos de Isac (2015). Ainda que SeP seja estruturalmente equivalente à projeção CP optativa, as propriedades formais não coincidem, uma vez que SeP introduz o traço de $2^{\mathrm{a}}$ pessoa, que será valorado pelo sujeito da oração imperativa, enquanto o CP optativo introduz o traço de primeira pessoa. Na análise de Zanuttini (2008), a sentença imperativa é uma projeção JP, não havendo, portanto, nenhuma categoria equivalente ao CP optativo e ao SeP, em Grosz (2011) e Isac (2015), respectivamente.

3.7.2 O traço diretivo (de segunda pessoa) no núcleo da categoria Mod

Conforme observamos inicialmente, a interpretação de uma sentença imperativa está associada a uma condição pragmática específica e especializada: um indivíduo emissor de uma elocução que é caracterizada por uma força ilocucionária diretiva direcionada a um destinatário ou um conjunto de indivíduos que correspondem a um conjunto de destinatários. Nesse sentido, as sentenças imperativas possuem uma força ilocucionária característica, diferente das sentenças declarativas e interrogativas. Sentenças em que a força ilocucionária não é orientada obrigatoriamente para um destinatário ou quantifica sobre um conjunto formado por um ou mais indivíduos além do destinatário geralmente são realizadas por outros paradigmas verbais diferentes do imperativo.

Diante da observação de que sentenças imperativas possuem força ilocucionária diretiva, vários estudos propõem associar sua realização à presença de traços alojados na categoria C. Conforme dito anteriormente, nosso trabalho assume a hipótese de que a categoria $\mathrm{C}$ apresenta traços associados à primeira pessoa na relação com um operador EX em seu especificador, que representa a expressão do emissor no ato de elocução. Seguindo o estudo de Zanuttini (2008) e de Isac (2015), assumimos que a estrutura imperativa do PB apresenta uma categoria dedicada à codificação do destinatário embora, suas propriedades sejam distintas em outros aspectos (JP é uma projeção 
associada à modalidade deôntica em que é codificado o destinatário, enquanto SeP refere-se ao evento de fala, e seleciona a projeção ModP, que codifica a modalidade dêontica). Na presente análise, postulamos que o núcleo $\mathrm{CP}$ optativo seleciona o sintagma codificador da modalidade deôntica, que hospeda o traço de pessoa associado ao destinatário, o qual corresponde à projeção JP e ModP, na análise de Zanuttini (2008) e Isac (2015), respectivamente. É o que representamos em (53);

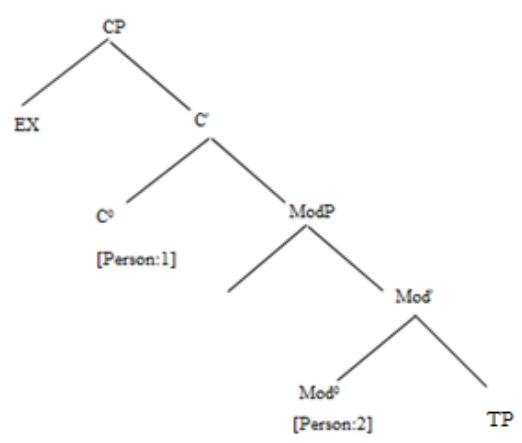

Conforme proposto nas análises de Zanuttini (2008) e Isac (2015) (cf. seções 3.4 e 3.5), as línguas distinguem as sentenças com as formas verbais do imperativo verdadeiro e do imperativo subjuntivo/ supletivo. No primeiro caso, o traço de $2^{\mathrm{a}}$ pessoa interpretável (em SeP e JP) é valorado mediante Agree pelo DP na posição de sujeito. Em Zanuttini (2008), o imperativo verdadeiro é considerado não finito, e a projeção XP, selecionada pelo núcleo Jussivo, tem um núcleo deficiente, em relação aos traços phi/ Caso e de Tempo, o que explica que o sujeito seja licenciado na relação com JP, por intermédio de Agree. Em Isac (2015), o núcleo Se (evento de fala), que hospeda o traço de $2^{\mathrm{a}}$ pessoa, seleciona ModP, que codifica a modalidade deôntica, cujo núcleo seleciona, por sua vez, FP, este último responsável por alojar o sujeito da oração imperativa, que terá seus traços valorados pela projeção SeP.

No caso de orações imperativas subjuntivas, ambas as análises postulam a realização de traços phi em projeções específicas, TP e FP, respectivamente. Na presença de partículas subjuntivas ou de traços flexionais de subjuntivo no verbo, é acionada a operação Agree, exatamente como em contextos finitos de sentenças declarativas e interrogativas, o que explica a possibilidade de sujeitos de primeira, segunda e terceira pessoa. 
Portanto, no que tange à projeção do traço de segunda pessoa inerente em SeP e do traço deôntico em ModP, concordamos com Isac (2015) em relação ao fato de que a projeção jussiva (JP) proposta por Zanuttini (2008) não possui as mesmas características. Por outro lado, Isac (2015) apresenta um núcleo em Mod com traços EPP a fim de garantir a identificação entre os traços postulados para a configuração imperativa especializada. Diante dessas possibilidades de análise, consideramos ainda a argumentação de Zanuttini (2008), em que é associada à projeção jussiva a possibilidade de realizar um conjunto de sentenças com diferentes modalidades. Segundo a autora, semanticamente, essas sentenças têm a particularidade de impor um requerimento ou uma expectativa ao(s) participante(s) da conversa: sentenças imperativas impõem um requerimento ao destinatário, sentenças exortativas impõem esse requerimento em ambos os participantes da conversa e sentenças promissivas são caracterizadas pela imposição desse requerimento ao próprio falante. Essas possibilidades podem ser observadas nos dados a seguir, do coreano, em que cada requerimento é codificado morfologicamente na mesma posição/ configuração, conforme aponta Zanuttini (2008).

(54) a. Cemsiym-ul mek-ela. (imperative/imperativo)

lunch-ACC eat-IMP

Eat lunch! / 'Coma o almoço!'

b. Cemsiym-ul mek-ca. (exhortative/ exortativo)

lunch-ACC eat-EXH

Let's eat lunch. /'Vamos comer o almoço.'

c. Nayil cemsiym-ul sa-ma. (promissive/ promissivo)

tomorrow lunch-ACC buy-PRM

' I will buy lunch tomorrow.' / 'Eu vou comprar o almoço amanhã.'

(ZANUTTINI 2008:214)

Por essa razão, retemos a projeção jussiva, considerando que, juntamente com o $\mathrm{CP}$ optativo constitui o sistema optativo/jussivo das orações imperativas no PB. Essa configuração corresponde às estruturas ditas imperativas subjuntivas no que se refere à possibilidade de não impor restrição de pessoa aos sujeitos. No entanto, distingue-se por não apresentar uma forma verbal específica associada ao subjuntivo - embora não 
apresente uma forma verbal específica para o imperativo. Essa configuração caracterizase por não exigir o movimento do verbo para $\mathrm{C}$, o que interage com a possibilidade de o verbo ocorrer na série supletiva do indicativo e do subjuntivo. O uso variável dessas formas na sentença optativa é então associado à neutralização da oposição indicativo vs subjuntivo no sistema verbal no PB, conforme propõe Ferreira Junior (2011). Igualmente, nessa configuração, na presença das formas verbais supletivas, não há restrição à ocorrência de marcadores negativos.

Finalmente, a existência de uma projeção com essas características permite explicar a existência de sujeitos abertos em posição pré-verbal, em sentenças imperativas no PB, com interpretação não marcada, o que permite vinculá-la a um efeito de polidez, conforme referido anteriormente (cf, FERREIRA JUNIOR; SALLES 2016). Essa questão será detalhada a seguir.

\subsubsection{Posicionamento dos sujeitos nas sentenças imperativas do PB}

A princípio, é necessário deixar claro que sujeitos de sentenças imperativas são considerados genuinamente sujeitos, e não vocativos. A literatura ${ }^{45}$ apresenta uma clara distinção entre vocativos e sujeitos de imperativas, demonstrando que, nas imperativas, os sujeitos têm um comportamento idêntico ao de sujeitos de outros tipos de sentenças.

Isac (2015) apresenta três argumentos que demonstram a diferença entre sujeitos de imperativas e vocativos. O primeiro argumento diz respeito à prosódia. Enquanto vocativos são separados do restante de uma sentença por meio de uma pausa na entonação, os sintagmas nominais sujeito em sentenças imperativas não necessitam dessa mesma pausa, conforme ilustrado em (54), com dados da autora, extraídos de Rupp (2003: 56-57).

(55) a. Truckdrivers, the rule is to keep to the right.

'Caminhoneiros, a regra é manter-se à direita.'

b. *Truckdrivers the rule is to keep to the right.

'Caminhoneiros a regra é manter-se à direita.'

c. Truckdrivers keep to the right!

45 Isac (2015) cita Levenston (1969); Stockwell et al. (1973); Schmerling (1975); Davies (1986); Beukema and Coopmans (1989); Zhang (1991); Henry (1995); Downing (1998); Potsdam (1998); Jensen (2003); Rupp (2003) e Zanuttini (2008) como autores que demonstram que o sujeito em sentenças imperativas apresenta comportamento prototípico de sujeitos. 
'Caminhoneiros mantenham-se à direita.'

d. Truckdrivers, keep to the right!

'Caminhoneiros, mantenham-se à direita.'

(ISAC 2015: 81)

O segundo argumento diz respeito ao fato de que certas expressões que podem ser utilizadas como sujeito de sentenças imperativas não podem ser utilizadas como vocativos, conforme ilustrado em (56), com dados da autora, sendo (56a) extraído de Rupp (2003:58).
a. Nobody make a move!
'Ninguém faça nenhum movimento!'
b. *Nobody, make a move!
'Ninguém, faça nenhum movimento!'

(ISAC 2015: 81)

Isac (2015) aponta ainda que vocativos não podem acionar concordância com terceira pessoa ou ligar pronomes de terceira pessoa, mesmo sendo uma categoria que manifesta inerentemente o traço de terceira pessoa, conforme ilustrado em (57), com dados da autora, sendo (57a) extraído de Rupp (2003: ex. 41a/42a).

(57) a.*Everybody ${ }_{i}$, take out their , $_{i}$ books!

'Todos, peguem os livros deles!'

b. Everybody ${ }_{i}$ take out their ${ }_{i}$ books! $^{\prime}$

'Todos peguem os livros deles!'

No exemplo, como o termo 'everybody' está separado do resto da sentença, há uma pausa na entonação, o que interrompe a coindexação entre esse termo e o pronome possessivo de terceira pessoa 'their'. Por outro lado, como não há quebra de entonação, a ligação entre o sujeito e o pronome que o recupera não é interrompida.

Além disso, Isac (2015) aponta ainda outras três propriedades a respeito da caracterização de sujeitos de imperativas como sujeitos prototípicos. Em primeiro lugar, sujeitos de imperativas podem ser passivizados da mesma maneira que sujeitos de declarativas, conforme ilustrado em (58), com dados da autora, extraídos de Rupp (2003: 64). 
(58) a. He was caught speeding.

'Ele foi pego correndo.'

b. Don't anyone be caught speeding!

'Ninguém seja pego correndo!'

(ISAC 2015: 82)

Outro fator apresentado é que sujeitos de imperativas podem ser alçados, ou seja, podem se mover para posições mais altas da mesma maneira que sujeitos de outros tipos de sentença, conforme ilustrado em (59), com dados da autora, extraídos de Rupp (2003: 64).

(59) You just appear you to be sick when your wife comes in!

'Você parece

(ISAC 2015: 82)

Com base nas características apontadas por Isac, observamos que as sentenças imperativas no PB possuem tais características, ainda, outras propriedades relacionadas à realização de sujeitos. Assim, na estrutura com a pausa delimitadora da função vocativa, existe a restrição ao uso do pronome ninguém, à ligação anafórica do pronome de $3^{\mathrm{a}}$ pessoa, como nos pares (60a-b), (61a-b), (62a-b), além da possibilidade de realizar a voz passiva e o alçamento, conforme ilustrado em (61) e (63).

(60) a. Ninguém se mexa/mexe!

b. *Ninguém, se mexa/ mexe!

(61) a. Todo mundo ${ }_{i}$, leve lleva seus $_{\mathrm{i}}[3 \mathrm{p}]$ livros!

b. Todo mundo leve/leva seus $\mathrm{i}_{\mathrm{i}[\mathrm{p}] /[2 \mathrm{p}]}$ livros!

(62) a. Ele foi pego correndo.

b. Ninguém seja pego correndo!

(63) Você pareça/? parece você estar doente quando sua mulher entrar! 
Conforme dito anteriormente, o PB admite sentenças imperativas com sujeito em ordem SV, com interpretação não marcada, uma característica que o distingue do português europeu (e de outras línguas românicas) e o identifica com o inglês. Em nossa análise, propomos que a estrutura sintática com projeção do sistema optativo/ jussivo permite realizar a estrutura imperativa do $\mathrm{PB}$, e tem implicações para a sintaxe do sujeito.

A princípio, conforme mencionado anteriormente, assumimos que as sentenças imperativas apresentam dois eventos: um desempenhado pelo emissor e outro desempenhado pelo destinatário. Para aplicar essa ideia, recuperamos o esquema em (44), repetido a seguir como $(64)^{46}$.

(64) [se Eu (falante) causo [Ae você (destinatário) causar $p$ [sBe o sujeito fazer algo]]]

Conforme mencionado, nas sentenças imperativas do $\mathrm{PB}$, esse primeiro participante é introduzido por meio do operador optativo EX, que é responsável por captar a expressão do desejo do emissor no ato de elocução. Esse operador, característico das sentenças optativas, é realizado no PB em razão das sentenças imperativas subjuntivas/ indicativas raízes serem a forma canônica de manifestação da força ilocucionária diretiva no PB. Nesse sentido, o C imperativo no PB é marcado para a primeira pessoa, que representa o emissor.

A categoria C optativa, por sua vez, seleciona a projeção JP (=ModP), responsável por alojar o destinatário. O destinatário é o responsável pelo segundo

\footnotetext{
${ }^{46}$ Agradecemos ao Prof. Dr. Marcus Lunguinho pela observação quanto à dupla relação de causa proposta para as sentenças imperativas, no sentido de haver (ou não) uma leitura causativa se o enunciado é marcado para a interpretação irrealis. Consideramos a dupla relação de causa das sentenças imperativas em dois pontos: primeiramente, a relação de causação 1 é desencadeada pelo Emissor no momento em que a sentença é proferida, sendo esta marcada para a interpretação realis. Na realização desse enunciado, o Emissor descreve um evento caracterizado por uma expectativa de realização por parte do Destinatário - causação 2. O caráter realis do primeiro evento é mantido em razão de haver a certeza quanto à emissão do comando, e o caráter irrealis do segundo evento deve-se a não haver certeza quanto ao cumprimento do comando expresso pelo ato de elocução. O evento imperativo é caracterizado pela modalidade irrealis exatamente por não haver certeza sobre a concretização do comando dado pela elocução imperativa. Nesse ponto, gostaríamos de fazer um paralelo com sentenças causativas como 'fez/mandou que João saísse', em que o verbo da oração subordinada ocorre no subjuntivo, mas o evento da oração encaixada será interpretado como realis ou irrealis a depender do auxiliar causativo (e não do verbo da encaixada, que manifesta o verbo no subjuntivo). Assim, o caráter irrealis é determinado nas sentenças imperativas mediante a possibilidade de o Destinatário assumir o comando dado pelo emissor mas isso não exclui que existam dois eventos na estrutura do enunciado imperativo.
} 
evento causado (causar no sujeito a realização de algo) e recebe, dessa forma, a orientação diretiva da sentença representada sintaticamente pelo traço de segunda pessoa. Dessa maneira, enquanto o emissor é marcado para primeira pessoa, o destinatário é marcado para o traço de segunda pessoa. Assim, os participantes do ato de elocução são captados pela sintaxe ${ }^{47}$. É o que podemos ver em (65).

\footnotetext{
${ }^{47}$ Agradecemos à $\operatorname{Prof}^{\mathrm{a}} \mathrm{Dr}^{\mathrm{a}}$. Jânia Ramos pelo questionamento a respeito da relação entre o componente pragmático e o imperativo no $\mathrm{PB}$. Em nossa proposta, consideramos que a configuração estrutural do imperativo no PB - desde a perda do imperativo verdadeiro até a existência de uma configuração que permite diversos matizes de polidez - espelha as modificações na estrutura das relações sociais no decorrer do tempo, ou seja, a ordem social desencadeou as mudanças na língua. A esse respeito, Gaglieti; Barbosa (2006) apresentam um trabalho sobre 'brasilidade', fundamentado na concepção teórica do "dilema brasileiro", adotada por Roberto da Matta. Ao comentarem a obra Raízes do Brasil, de Sérgio Buarque de Holanda, os autores afirmam que "a cordialidade é uma tentativa de reconstrução, no plano da sociedade, do mesmo tipo de sociabilidade, assentada em laços comunitários, que vigorava na família patriarcal. Seriam exemplos dessa tentativa algumas formas de linguagem (...) e a busca de intimidade no tratamento dispensado pelos indivíduos à autoridade." Os autores ainda destacam, como estratégias de legitimação, o convívio mais emocional que racional sendo o elemento definidor da brasilidade e da cultura dos povos latino-americanos. Assim, destacam que “(...) essa especificidade da cultura latinoamericana, e especialmente da brasileira, relativiza a hierarquia, a respeitabilidade dos nomes de família e os títulos distintivos, incitando os "desiguais" em qualquer escala hierárquica a, logo que possível, buscarem no convívio íntimo a estratégia legitimadora das relações sociais." (GAGLIETI; BARBOSA 2006:36). Considerando essas informações, é possível propor que as mudanças na hierarquia das relações sociais implicam reflexos no comportamento linguístico dos falantes do $\mathrm{PB}$, desencadeando a perda de marcas de distanciamento discursivo, como (i) a perda do imperativo verdadeiro associada ao sistema de tratamento e das restrições sintáticas; (ii) a reanálise do sistema pronominal; (iii) a neutralização das formas verbais do indicativo e do imperativo; (iv) o uso variável do indicativo e do subjuntivo na expressão do imperativo e também a existência de um CP configurado por um operador optativo, que marca a expressão do emissor na elocução imperativa, juntamente com uma categoria responsável por marcar a segunda pessoa no ato de elocução imperativo e os matizes de polidez presentes no traço diretivo. Dessa maneira, podemos indicar a possibilidade de o componente pragmático estar associado à realização do modo imperativo no $\mathrm{PB}$, o que vem ao encontro dos resultados das pesquisas gerativistas que buscam codificar essa relação no domínio do CP.
} 
$(65)$

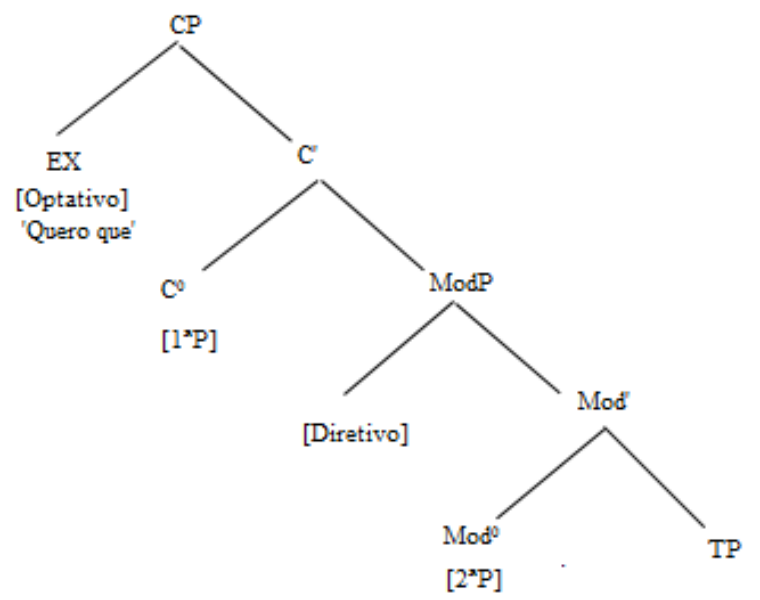

Conforme mencionado anteriormente, as sentenças imperativas do PB são formadas por sentenças raízes com formas verbais subjuntivas e indicativas, que não manifestam restrição à pessoa do discurso. Nesse sentido, têm os traços phi e de Caso completos checados com o núcleo funcional FP (ou TP), selecionado por Mod/J. Essa situação se confirma pela possibilidade de realizar o enunciado imperativo em que o emissor está incluído no conjunto dos destinatários, seja por identidade referencial, seja por uma leitura inclusiva, conforme ilustrado a seguir.

(66) a. [que] Eu seja curado!

b. (nós) vamos em paz!

Com base nas considerações apresentadas, passamos a observar outros aspectos da realização do sujeito em sentenças imperativas no PB. Verificamos que o PB apresenta três possibilidades de realização do sujeito em sentenças imperativas: a realização nula, a pré-verbal e a pós verbal, conforme ilustrados em (67a), (67b) e (67c), respectivamente. ${ }^{48}$

\section{a.Abra/Abre a porta!}

b.Você abra/abre a porta!

\footnotetext{
${ }^{48}$ Não incluímos na discussão o uso do pronome 'tu' nesse mesmo contexto - uma variante com distribuição regional. Aprofundar a discussão sobre o uso variável de 'tu' e 'você' vai além do escopo deste trabalho, embora seja relevante para a discussão sobre a reanálise pronominal observada no PB (cf. Scherre 2007). Neste ponto da discussão, interessa observar essencialmente a posição do sujeito, em oposição à estrutura de sujeito nulo.
} 
c.Abre/Abra você a porta!

Um primeiro ponto a destacar é que as sentenças imperativas do PB na configuração SV com a forma verbal do indicativo manifestam ambiguidade de interpretação imperativa/ declarativa, conforme ilustrado a seguir (68a-b) - o que não se verifica na estrutura com a forma verbal de subjuntivo (69).

(68) a.Você abre a porta. (declarativo)

b.Você abre a porta! (imperativo)

(69) Você abra a porta. (imperativo/*declarativo)

Esse contraste se resolve na presente análise, em termos da configuração optativa/ jussiva, associada à sentença imperativa, a qual capta, por hipótese, o sistema de representação temporal de Reichenbach (1947), que define os tempos (verbais) a partir de três pontos de localização: o momento de fala $(\mathrm{S}=$ speech), o ponto de referência $\mathrm{R}$ (point of reference) e o ponto do evento $\mathrm{E}$ (point of event). Na estrutura marcada pela interpretação assertiva (68a), tem-se um leitura estativa e habitual do predicado, enquanto naquela marcada pela força ilocucionária imperativa (68b), tem-se um leitura eventiva e episódica do predicado. Pode-se então afirmar que, no primeiro caso, o momento de fala $(\mathrm{S})$ coincide com o momento de referência (R) e com o momento do evento (E), o que gera a configuração S, R, E (Você entra aqui [sempre]). No segundo caso, o momento de fala (S) é anterior ao ponto de referência (R) e ao ponto do evento (E), estes últimos sendo simultâneos, o que gera a configuração $S-R$, $\mathrm{E}$ (Você entra aqui [agora]!).

Antes de passarmos à derivação das estruturas imperativas no PB, gostaríamos de fazer algumas observações.

Seguindo a concepção de Chomsky (2008) quanto à transmissão de traços phi na periferia da oração para a projeção funcional TP responsável por licenciar o sujeito da oração, postulamos que o núcleo Mod, com o traço de $2^{\mathrm{a}}$ pessoa, pode transmitir esses traços para o núcleo $\mathrm{F}^{\circ}$. Ao transmitir os traços para $\mathrm{F}$, o sujeito em SpecFP verifica os traços de pessoa e Caso do sujeito por meio da relação Agree. 
(70)

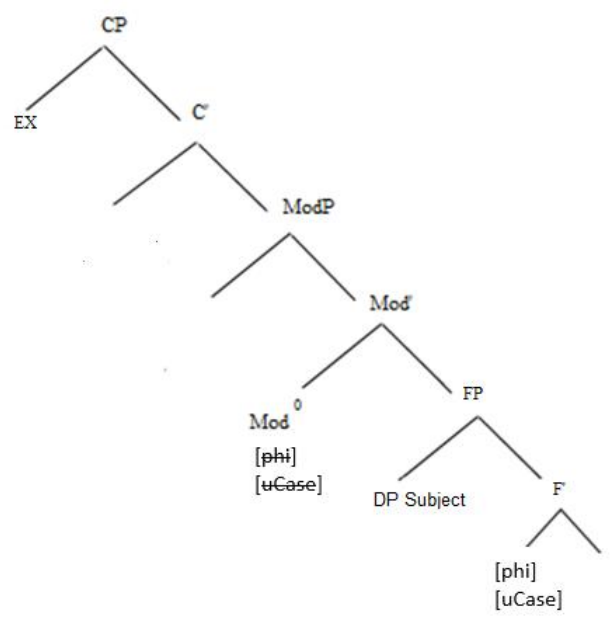

No caso da realização de sujeitos com traço de pessoa intrinsecamente valorados, o traço de pessoa no núcleo T entra em relação de Concordância com o sujeito DP. O traço não interpretável em F será checado e eliminado por meio dessa relação.

(71)
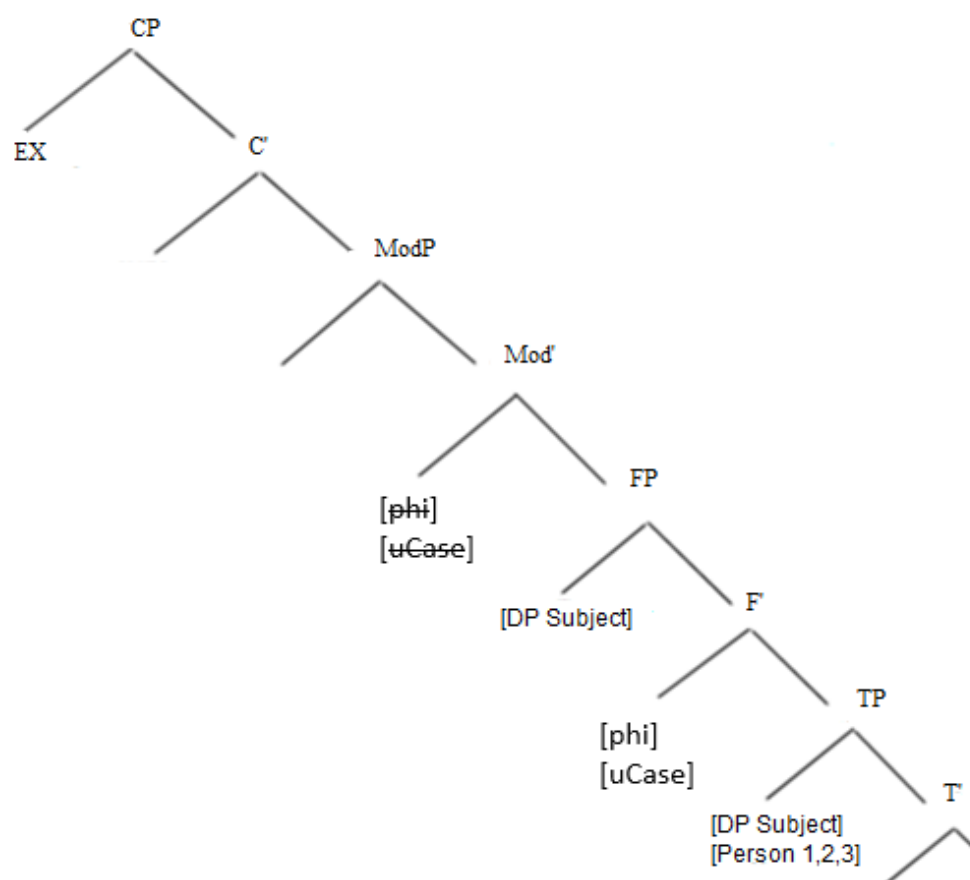

No caso de sujeitos com traço de pessoa intrinsecamente valorados (DPs definidos ou pronomes abertos) nossa proposta segue Isac (2015), no que diz respeito à 
presença de um traço de pessoa que permite a ocorrência de sujeitos de primeira ou terceira pessoa.

No caso de sujeitos com traço de pessoa intrinsecamente valorados, o traço de pessoa no núcleo T entra em relação de Concordância com o sujeito DP. O traço não interpretável em F será checado e eliminado por meio dessa relação.

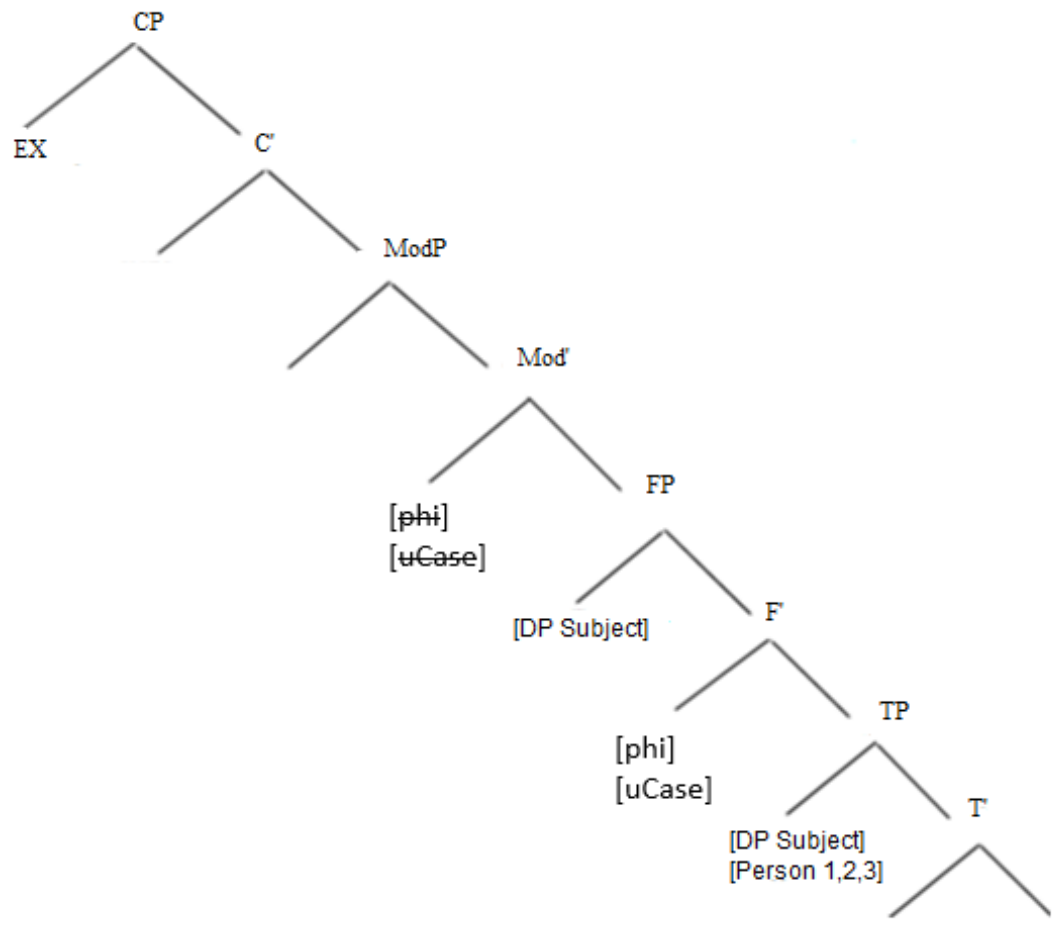

$\mathrm{Na}$ ocorrência de sujeitos com traço de pessoa não valorados, (nomes nus, expressões quantificadas e nomes próprios), esses DPs podem ser valorados tanto como segunda ou terceira pessoas. Seguimos Isac na explicação de que essas duas interpretações estão associadas a dois diferentes traços: o de terceira pessoa, default, adjungido em FP, e a de segunda pessoa em Mod. Segundo Isac (2015), esses DPs podem gerar duas interpretações:

(i) Interpretação de terceira pessoa

a. (Ms Hauser) Boysi raise their ${ }_{i}$ hands!

b. 


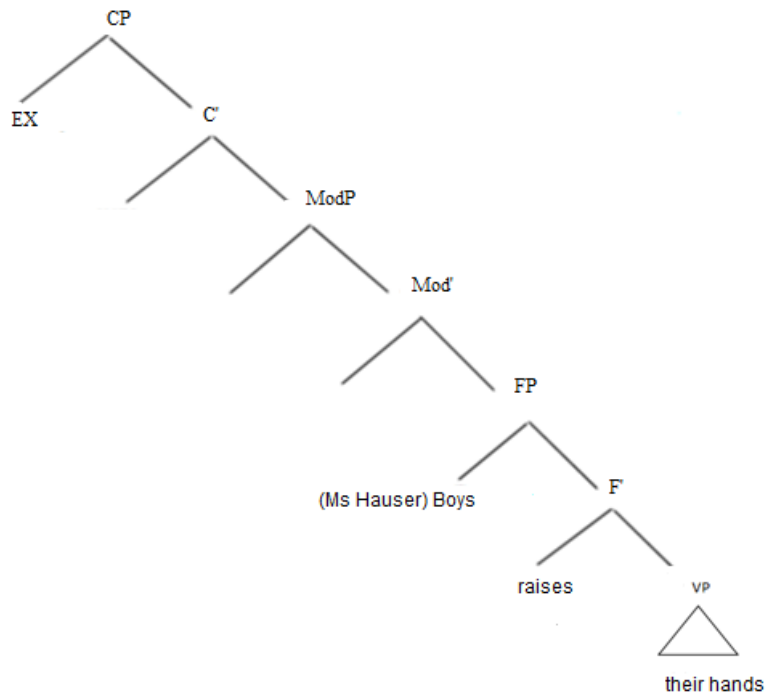

(ii) Interpretação de segunda pessoa

a. Boysi raise your $r_{i}$ hands!

b.

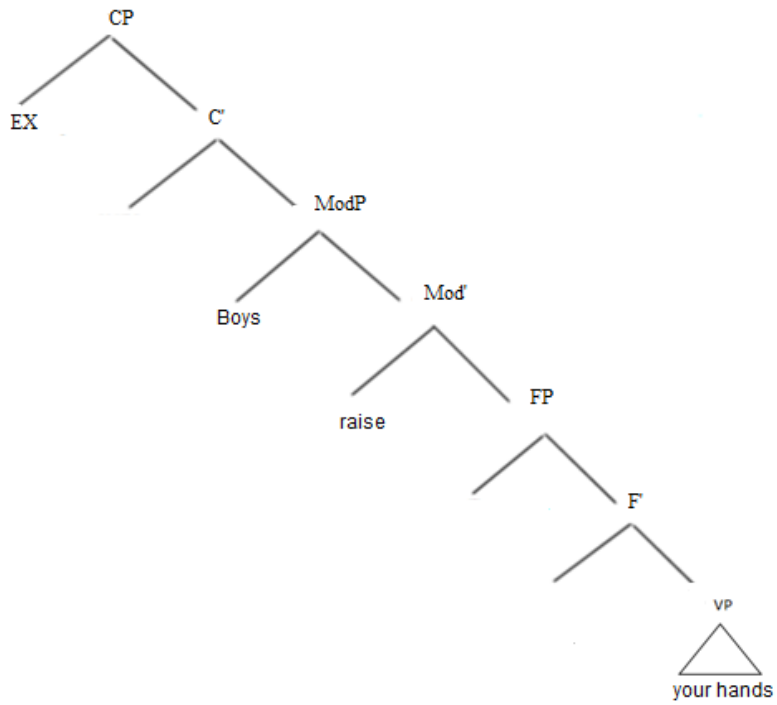

De posse dessas informações, pasamos à análise da derivação das sentenças no PB.

3.7.4 A derivação de sentenças imperativas no PB

O primeiro caso de derivação das sentenças imperativas do PB que analisaremos é a oração imperativa sem realização de sujeito lexical, conforme a estrutura em (74) 


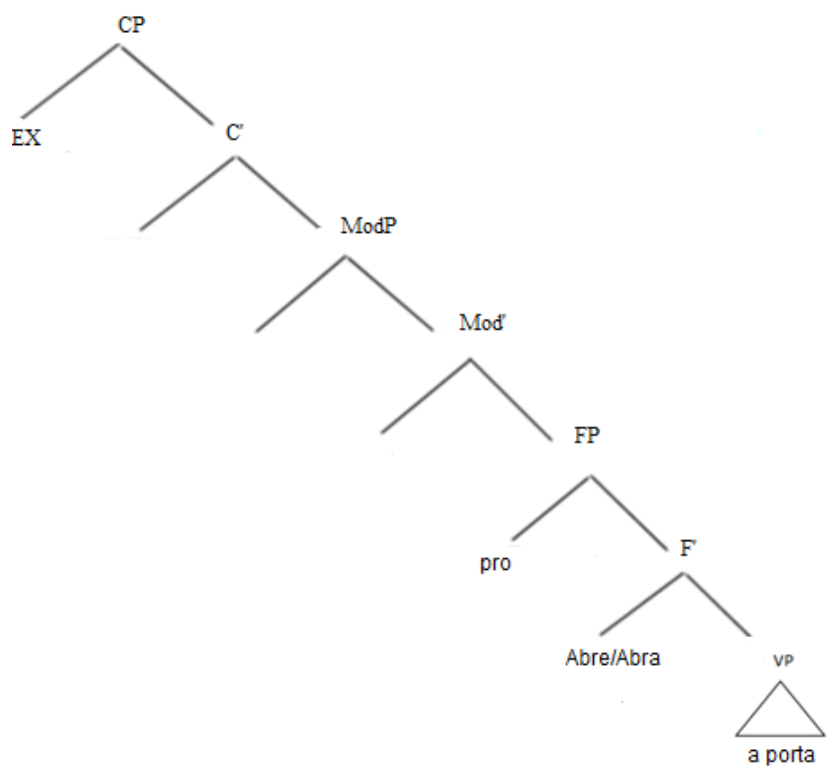

Seguindo Isac (2015), assumimos que o núcleo Mod pode transmitir os traços de pessoa e de Caso para $\mathrm{F}$. O sujeito não é realizado lexicalmente. O verbo verifica os traços por meio da relação Agree com o núcleo Mod e permanence hospedado no núcleo de F.

Na sentença imperativa (67a) derivada em (74), o verbo (flexionado) é inserido em vP/VP, se move para $\mathrm{T}$ e, posteriormente, para uma projeção funcional (FP). $\mathrm{O}$ sujeito é realizado como 'pro' em specvP, e move-se para specTP, onde verifica os traços phi não-interpretáveis de $\mathrm{T}$, e valora o traço de Caso (nominativo). Uma vez verificado o traço de Caso, pro em spec FP fica indisponível para valorar o traço de (segunda) pessoa em Mod por meio de Agree - o que não interfere na derivação, pois esse traço permanece interpretável em relação à orientação para o destinatário.

$\mathrm{Na}$ sentença imperativa em (67b) derivada em (75), com a configuração de sujeito pré-verbal realizado lexicalmente com a forma verbal do subjuntivo, o verbo é hospedado em FP, projeção dominada por Mod. A categoria Mod compartilha os traços de pessoa e Caso com o núcleo de F, permitindo a leitura imperativa da sentença. Além disso, o sujeito em specFP verifica os traços por meio da relação de concordância com o núcleo F. 
(75)

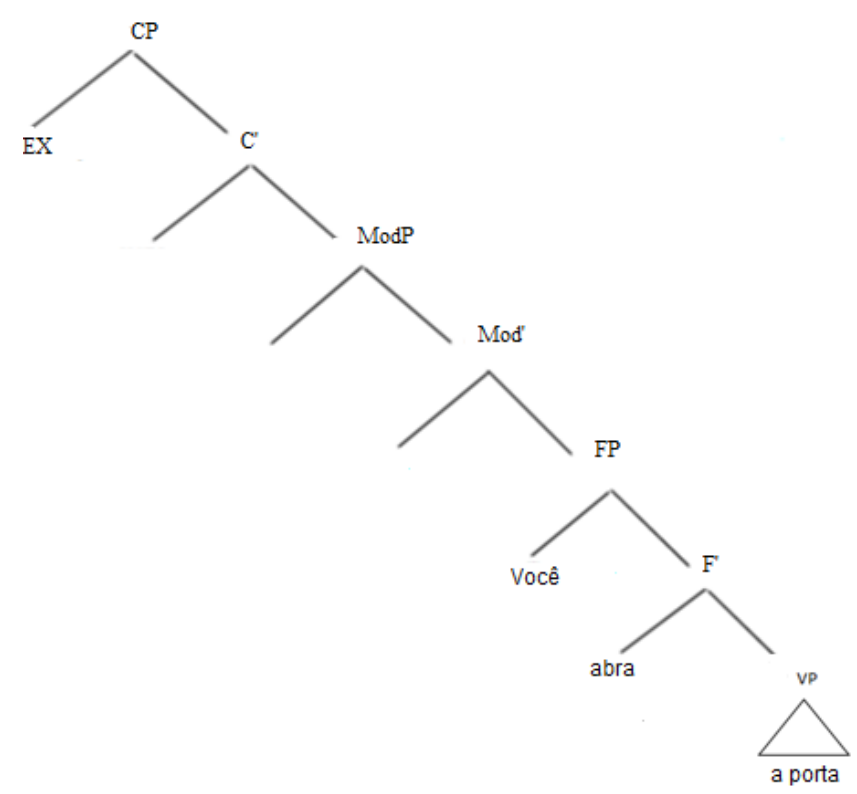

Relevante neste ponto é o fato de a estrutura admitir o sujeito de primeira pessoa, de segunda pessoa e de terceira pessoa, conforme ilustrado a seguir (76):

(76) a. (*que) Eu abro a porta!/ */?(que) eu abra a porta!

b. ?(/*que) A professora abre a porta!/ (que) a professora abra a porta!

c. (que) Ninguém (de nós/vocês/deles) abre a porta!/(que) ninguém (de nós/vocês/deles) abra a porta!

A projeção do sistema optativo/jussivo permite então licenciar o DP sujeito Ninguém em specTP/FP, por intermédio de Agree, restando disponível o traço interpretável do destinatário ( $2^{\mathrm{a}}$ pessoa) em J/Mod e do emissor ( $1^{\mathrm{a}}$ pessoa) em

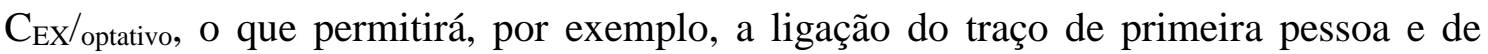
segunda pessoa, em (69c), simultaneamente ao traço de terceira pessoa associado ao DP ninguém. Igualmente relevante é a distribuição da partícula que, a qual analisamos (parcialmente) conforme Isac (2015), como uma categoria associada à estrutura imperativa subjuntiva optativa, realizada em C (cf. seção 3.5.3) - na presente análise $\mathrm{C}_{\text {optativo/Ex }}$ (não contemplado em Isac), daí a diferença em relação ao que declarativo. Os dados em (76) apontam para contrastes interessantes em relação à pessoa, o que se 
constata por exemplo em relação ao dativo ético (referido anteriormente), Deixamos essa questão para investigação futura.

Retomando as sentenças imperativas com a forma verbal associada ao indicativo e com sujeito expresso na ordem SV, em que encontramos a ambiguidade entre a leitura imperativa e a declarativa (cf. 68), repetido em (76), cabe agora relacionar à derivação proposta.

a. Você abre a porta!

a'. Você abre a porta *[sempre/ todos os dias].

A (aparente) ambiguidade entre as sentenças é resolvida se considerarmos a existência de estruturas distintas para a expressão de sentenças imperativas e declarativas, nos termos propostos nos estudos citados e também na presente análise. Enquanto no enunciado declarativo, o verbo é realizado no núcleo da projeção TP e o sujeito no especificador da projeção TP, no enunciado imperativo com verbos na forma indicativa (e subjuntiva), o verbo é, por hipótese, alçado para o núcleo de FP. O núcleo fase (Mod) compartilha o traço imperativo, além de compartilhar o traço de $2^{\mathrm{a}}$ pessoa com o núcleo de $\mathrm{F}$, permitindo a leitura imperativa da sentença.

As sentenças declarativas não possuem essa força ilocucionária e, por esse

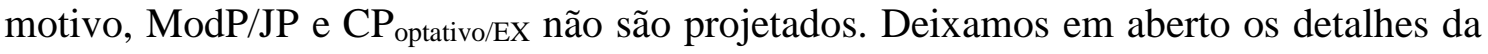
derivação do predicado estativo habitual.

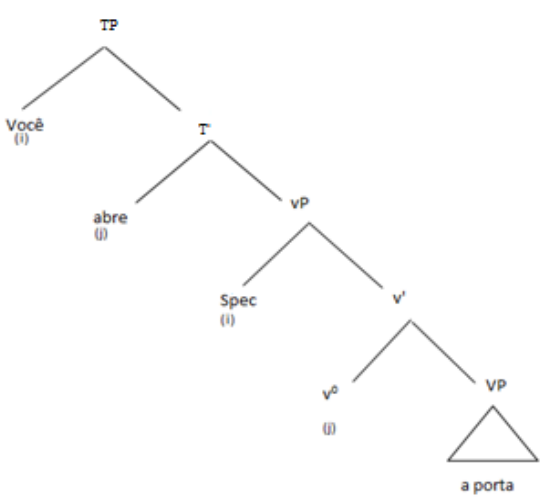


Passamos finalmente à estrutura em que o DP sujeito é realizado em posição pós-verbal. A interpretação captada para essa estrutura parece ser marcada (por foco contrastivo ou por foco identificacional). Observemos os pares em (78), (79) e (80), em que se depreende um contraste, que parece ser resolver por meio de uma interpretação marcada para os casos em (b) (foco e tópico pendente).

(78) a. Você abre/abra a porta! (DP pronominal)

b. Abre/Abra você a porta!
a. O André abre a porta!
(DP nominal)

b. Abre o André a porta (não você)!
a. Ninguém abre a porta!
(DP negativo)

b. Abre ninguém a porta!

Para esse momento, nosso interesse é explicar a relação entre a posição de sujeito (pós-verbal) e a estrutura proposta as estruturas imperativas do PB. Questões associadas a focalização exigem a observação de outras variáveis que não consideramos nessa análise.

Considerando-se que as sentenças imperativas com ordem VS possuem uma leitura marcada, assumimos que a derivação dessas sentenças ocorre com o movimento do verbo para a posição de núcleo de ModP. Nessa posição, o verbo assume uma leitura deôntica, valorando os traços imperativo/ $2^{\mathrm{a}}$ pessoa diretamente no núcleo de Mod.

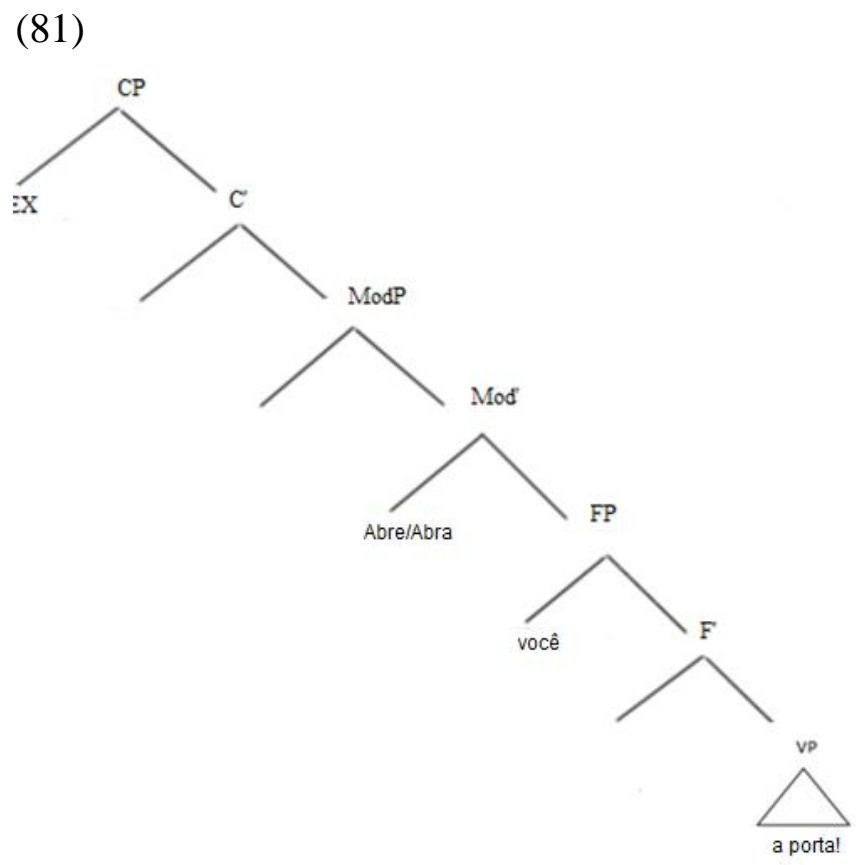


Aqui observamos um interessante contraste com a ocorrência de sentenças imperativas com a ordem SV. Na ordem VS o verbo parece assumir uma leitura deôntica mais forte, fato também evidenciado pelo contraste na leitura imperativa (Abre você, não ele!). Em nossa análise, atribuímos essa leitura deôntica mais forte à posição argumental do verbo. Se nas sentenças imperativas com a ordem SV, a hospedagem do verbo em FP permite um maior matiz de polidez, espera-se que em Mod - categoria que domina FP - o traço imperativo seja mais forte. Essa generalização pode ser atestada também pelo fato de que, em sentenças imperativas com a forma verdadeira há uma combinação entre a posição de hospedagem do verbo (no núcleo de C) e um matiz de polidez menor em relação a verbos imperativos com a forma supletiva (com hospedagem em categorias mais baixas como FP ou TP) - conforme observado em Isac (2015). O desenvolvimento dessas questões será objeto de estudos futuros.

\subsection{Considerações finais do capítulo}

Este capítulo teve como objetivo apresentar uma proposta de análise a respeito da configuração estrutural das sentenças imperativas no português brasileiro (PB).

Nossa hipótese, apoiada em estudos prévios, é a de que o PB sofreu uma série de mudanças que neutralizaram propriedades do imperativo, o que desencadeou a desarticulação da gramática do imperativo verdadeiro nessa língua. Dessa maneira, propomos que os enunciados imperativos no PB são realizados em um sistema que se caracteriza por projetar um CP optativo que possui um especificador com um operador semântico (EX) relacionado à primeira pessoa (emissor), que consiste na elocução da força expressiva por meio da avaliação do status da proposição modificada numa escala contextual, que permite ao emissor direcionar ao destinatário a mensagem imperativa com diferentes matizes (ordem, pedido, súplica).

Em seguida, passamos ao estudo da categoria ModP/JussivoP, com base nas características apresentadas por Zanuttini (2008) e Isac (2015). Na presente análise, a interpretação da categoria Mod/Jussivo é responsável por codificar o traço diretivo nas

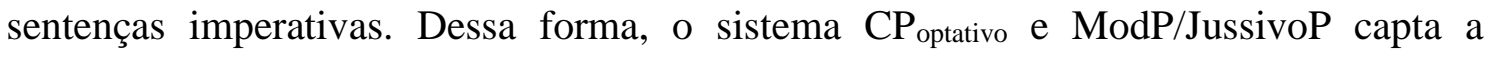
proposta de Isac (2015) de que as sentenças imperativas apresentam dois eventos de causa distintos: o primeiro relacionado ao emissor e o segundo relacionado à ação causada pelo destinatário da mensagem realizado na posição de sujeito. Nessa perspectiva, ao propor um CP que capta a expressão do emissor e um Mod que capta a 
ação do destinatário por meio do traço diretivo, entendemos que a sentença imperativa no PB exibe os dois eventos causados pela elocução imperativa. Nessa configuração,

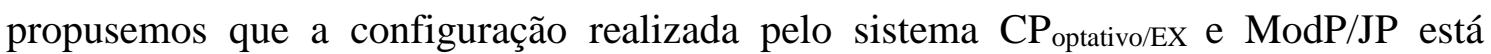
associada a um efeito de polidez, conforme apresentado por Isac (2015).

No capítulo seguinte, pretendemos demonstrar as características das sentenças imperativas em contexto de negação. A análise de aspectos sintáticos de sentenças imperativas negativas no PB complementa esse estudo, haja vista que uma das principais características que sentenças do $\mathrm{PB}$ exibem no contraste com sentenças imperativas formadas com verbos na forma imperativa verdadeira é a ampla possibilidade de realização de marcadores negativos, a saber pré-verbal, pós-verbal e com dupla negação. Afirmamos que essa ampla possibilidade está associada às propriedades da configuração estrutural das sentenças imperativas do PB, que são formadas por meio do supletivismo, com orações subjuntivas raízes que possuem uma categoria $\mathrm{C}$ especializada em função de um operador optativo que marca a expressão do emissor no contexto do ato de elocução. 


\section{CAPÍtULO 4}

\section{A INTERAÇÃO ENTRE SENTENÇAS IMPERATIVAS E AS ESTRATÉGIAS DE NEGAÇÃO NO PB}

\subsection{Objetivos do capítulo}

Este capítulo $^{49}$ investiga aspectos sintáticos e semânticos de sentenças imperativas negativas no português brasileiro (PB), com o objetivo de identificar as inovações apresentadas no contraste com o português europeu (PE), classificado como língua de imperativo verdadeiro de Classe I, conforme proposto por Rivero (1994) e Rivero \& Terzi (1995), relacionando-as à expressão dos enunciados imperativos no PB. Conforme amplamente observado na literatura (cf. Capítulo 1), o PE, em sentenças com imperativo verdadeiro, apresenta restrições a marcadores negativos. Para a formação do imperativo negativo, são usadas formas verbais advindas do modo subjuntivo, sendo essas formas conhecidas na literatura como supletiva, em oposição à forma verdadeira (ver Rivero 1994).

Conforme mencionado anteriormente, nossa hipótese de trabalho é a de que o PB não possui uma forma verdadeira de imperativo. Essa conclusão está formulada em estudos prévios (cf. Scherre et al. 2007, e referências ali citadas), sendo fortemente fundamentada na sintaxe da negação. Conforme mencionado anteriormente, o paradigma verbal imperativo no $\mathrm{PB}$ traz formas verbais inovadoras, que não estabelecem restrição ao uso da negação. Conclui-se que sua distribuição é comparável à das formas do subjuntivo, o que permite supor que, em ambos os paradigmas, são formas supletivas na expressão do imperativo.

Portanto, uma consequência de não haver uma forma verdadeira de imperativo no PB é a ausência de restrições na presença de marcadores negativos. Outro fator de interesse é que a sintaxe do imperativo negativo no PB permite a ocorrência de três diferentes estratégias de negação em relação à posição do marcador negativo: na posição pré-verbal (Neg-V), na posição pós-verbal (V-Neg) e simultaneamente em ambas as posições (Neg-V-Neg).

\footnotetext{
${ }^{49}$ Este capítulo, por retomar estudos prévios, desenvolve-se solidamente com base em minha dissertação de mestrado. [FERREIRA JUNIOR, M. N. A sintaxe da negação em configuração imperativa no português brasileiro. Dissertação de Mestrado. Universidade de Brasília. (2011)]
} 
Nosso objetivo é o de demonstrar que a configuração da sintaxe imperativa no $\mathrm{PB}$, no que se refere à presença e à posição dos marcadores negativos, é um dos fatores preponderantes para diferenciar parametricamente o modo imperativo no PB e no PE. Em particular, nas sentenças imperativas com marcadores negativos, é possível identificar diferenças sintáticas em contextos de dupla negação e de negação pós-verbal, o que nos motiva a investigar a natureza e a distribuição desses marcadores em correlação com o Ciclo de Jespersen, tendo em vista as inovações observadas no PB em relação ao uso desses marcadores.

Para construir a abordagem dos fenômenos apresentados, primeiramente apresentamos um breve histórico dos estudos sobre os marcadores negativos. Em seguida, para compreender a relação entre a negação e sentenças imperativas, apresentaremos a proposta de Rivero (1994), com o objetivo de demonstrar os aspectos sintáticos que restringem a ocorrência de marcadores negativos em sentenças com imperativo verdadeiro, tendo como hipótese associar o movimento do verbo ao licenciamento de traços formais na periferia da oração relacionados à interpretação diretiva/ imperativa. Continuaremos com a apresentação da proposta de Han (1999), que questiona a análise de Rivero (1994) quanto à impossibilidade de ocorrência da negação nas sentenças com imperativo verdadeiro. Han (1999) propõe que a restrição de ocorrência da negação se dá por um problema semântico, em razão do escopo da negação sobre a força ilocucionária imperativa.

Neste ponto, passamos a descrever como as mudanças no paradigma pronominal do PB influenciam na configuração do modo imperativo. Inicialmente, retomamos algumas questões apresentadas em Cardoso (2009), a respeito do papel da polaridade da estrutura e do tipo de pronome no contexto discursivo, no uso variável das formas do indicativo ou do subjuntivo na expressão do imperativo. Tendo em vista a relação demonstrada em Cardoso (2009) entre a presença da negação e as formas do subjuntivo, retomamos a análise de Vitral (2006) e de Ramos (2006), que apontam evidências do enfraquecimento do marcador negativo pré-verbal no PB, reconhecendo-o como uma "forma fraca", diferentemente da forma encontrada em posição pós-verbal (tônica). Além disso, a análise de Vitral e Ramos considera a coocorrência do marcador pósverbal (e da dupla negação) como uma forma inovadora no PB. Assumiremos, com esses autores, que o PB apresenta um processo de "gramaticalização" da negação préverbal, por um lado, e o surgimento de uma "negação adverbial" pós-verbal, por outro. 
Essas propriedades inovadoras interagem com as formas inovadoras da estrutura imperativa, como será demonstrado.

Na discussão, apresentamos, ainda, a análise de Biberauer \& Cyrino (2009), em que demonstram que a estrutura (V-NEG) não é permitida em oração encaixada ou com o preenchimento de sujeitos não definidos - em que se incluem as estruturas com verbos no imperativo -, em contraste com a configuração (NEG-V-NEG) que, por um lado, é compatível com orações infinitivas e encaixadas temporais e, por outro lado, não apresenta restrições quanto ao tipo de sujeito. Com isso, pretendemos verificar as restrições à ocorrência exclusiva do marcador negativo pós-verbal (V-NEG) em sentenças imperativas. Veremos, ainda, conforme Sousa (2015), a hipótese de três interpretações distintas para os três tipos de marcadores negativos. Em nossa análise, pretendemos demonstrar que esses fatores permitem caracterizar a sintaxe do imperativo negativo do PB como uma inovação, diferenciando-se em termos paramétricos do PE, com implicações para a sintaxe de sentenças imperativas.

\subsection{Apresentação do problema}

O problema apresentado neste capítulo diz respeito às diferenças entre o PE e o $\mathrm{PB}$, no que se refere à configuração de sentenças imperativas com marcadores negativos. Como apresentamos no capítulo 1, existem línguas em que as sentenças imperativas com a forma verdadeira não podem ser negadas, conforme se depreende dos dados do espanhol (castelhano), do grego moderno, e do português europeu, citados na seção 1.3.1.

Dessa maneira, observamos que o PE apresenta um paradigma específico para o modo imperativo, que se diferencia dos outros modos por apresentar uma especialização morfológica. A marca morfológica própria do imperativo interage com aspectos sintáticos peculiares ao modo imperativo. Entre os aspectos sintáticos característicos das sentenças imperativas que apresentam verbos com a forma verdadeira, está a restrição à coocorrência com marcadores negativos, conforme mencionado, e também com outras categorias, como a sintaxe dos pronomes complemento.

No entanto, o PB diferencia-se do $\mathrm{PE}$, no que diz respeito às restrições a marcadores negativos em sentenças imperativas (e também em relação à sintaxe do clítico). Em particular, o PB não possui restrições sintáticas na presença de marcadores 
negativos. As principais características do paradigma imperativo do PB, no que diz respeito à presença de marcadores negativos, é retomada a seguir:

Apresenta duas formas, independentemente da orientação ao interlocutor pela $2^{a}$ pessoa ou pela $3^{a}$ pessoa (gramatical)
(1)
a. Abre o presente!
b. Abra o presente!

Ambas as formas permitem marcadores negativos.
(2)
a. Não abre o presente!
b. Não abra o presente!

$\mathrm{O}$ PB ainda permite a realização de marcadores negativos com formas distintas e com ocorrência em diferentes posições.

(3) a. Não/Num liga/ligue a televisão porque está trovejando. (Neg-V)

b. Não/Num abre/abra a caixa não. (Neg -V-Neg)

c. Fica/fique triste não. (V-Neg)

Diante das diferenças apresentadas entre o PE e o PB na configuração do modo imperativo, especificamente no que diz respeito à presença de marcadores negativos, pretendemos investigar neste capítulo as seguintes questões: (i) a diferenciação entre marcadores negativos pré-verbais e pós-verbais; (ii) as restrições a marcadores negativos em sentenças com a forma verdadeira; (iii) as características da negação préverbal no PB; (iv) as diferenças no emprego de marcadores negativos em dupla-negação (Neg-V-Neg) e em posição pós-verbal (V-Neg) no PB; (v) a negação em sentenças imperativas do PB como uma questão estrutural vinculada ao ciclo de Jespersen para os marcadores negativos.

Para tanto, apresentamos sucintamente a análise de Zanuttini (1995) acerca dos marcadores negativos nas línguas românicas, a ser adotada na presente análise; em seguida, retomamos análises prévias sobre as restrições ao uso da negação com o imperativo verdadeiro, em oposição às formas supletivas; passamos finalmente a 
considerar as características inovadoras da negação no PB, relacionando-as às estruturas imperativas.

\subsection{Os tipos de marcadores negativos nas línguas românicas: Zanuttini}

(1995)

A análise de Zanuttini (1995) demonstra que podem ser encontrados dois tipos de marcadores negativos nas línguas românicas: um que pode negar a sentença independentemente e um segundo tipo que depende da coocorrência com outra partícula negativa pós-verbal. Zanuttini (1995) define essa distinção pela natureza do traço negativo dessas partículas (forte/fraco) e pela posição sintática que ocupam.

Os marcadores negativos com traço forte ocupam a posição de núcleo, podendo negar a sentença sem o auxílio de outro marcador negativo. Zanuttini (1995) propõe que esses marcadores ocorrem em uma categoria responsável pela checagem dos traços de polaridade da sentença. A autora chama essa categoria de PolP (Polarity Phrase), a qual é semelhante à categoria $\Sigma \mathrm{P}^{50}$, proposta originalmente por Laka (1990). ${ }^{51}$ Já os marcadores negativos que contêm um traço fraco ocorreriam em posição de adjunção ao núcleo de uma categoria funcional independente, funcionando como clítico.

Zanuttini (1995) propõe então que três padrões básicos de realização da negação são encontrados nas línguas por ela estudadas (espanhol, francês, piemontês, florentino etc.), conforme ilustrado em (4).

(4) a. Gianni a l'ha nen cappi tut. (piemontês) - negação pré-verbal:

Gianni didn't understand everything.

'Gianni não entendeu tudo'

b. I l'ai vist gnun. (piemontês) - negação pós-verbal

I have seen nobody.

'Eu não vi ninguém'

\footnotetext{
${ }^{50}$ Conforme observado por Jânia Ramos (c.p.), categorias do tipo $\Sigma$ P têm sido exploradas na teoria em outros domínios na periferia da oração, associadas à codificação da modalidade, conforme proposto em Tomic (2007). Nesse sentido, fica evidente a relação entre modalidade e polaridade. Essa questão é abordada neste trabalho com a hipótese da codificação da modalidade optativa nas sentenças imperativas no PB, o que será detalhado adiante.

${ }^{51}$ A contribuição de Laka (1990) é no sentido de demonstrar, por meio de dados do basco, a existência de uma projeção associada à polaridade da sentença (afirmativa/negativa) em posições distintas na projeção oracional, acima de TP ou abaixo de TP. A possibilidade de variação paramétrica explica a distribuição do marcador negativo. LAKA, I. (1990). Negation in syntax: on the nature of functional categories and Projetions. MIT, Tese de Doutorado.
} 
c. Jean n'aime pas la viande. (francês padrão) - dupla negação John doesn't like meat.

'John não gosta de carne.'

(ZANUTTINI 1995: 563, 570, 571)

Ao discorrer sobre as diferenças que as partículas negativas podem exibir na estrutura sintática, Zanuttini (1995) propõe que as línguas românicas apresentam dois marcadores de negação - o adverbial e o gramatical. O primeiro tipo, adverbial, é aquele que pode negar a sentença independentemente. É geralmente posposto e tônico, exibindo características de especificador.

Três características distinguem os marcadores negativos com caráter adverbial em relação aos marcadores gramaticais. Em primeiro lugar, os marcadores negativos com características adverbiais não possuem posição fixa em relação ao verbo, permitindo a interpolação de elementos, enquanto os marcadores gramaticais possuem posição fixa em relação ao verbo. Estes são sempre prepostos, inclusive com infinitivos, não admitindo nenhum elemento interpolado, salvo pronomes átonos. Tais fatos estão ilustrados nos exemplos a seguir, extraídos de Zanuttini (1994: 433, 434), com tradução e glosa nossas.

Quadro 4.1 Tipo de marcadores negativos

\begin{tabular}{|c|c|}
\hline Marcadores negativos do tipo adverbial & Marcadores negativos do tipo gramatical \\
\hline $\begin{array}{l}\text { [Piemontês] } \\
\text { a) Maria a mangia nen } \\
\text { Maria ela come não } \\
\text { "Maria não come" } \\
\text { b) Maria a l'ha nen parlá tant } \\
\text { Maria ela o tem não falado tanto } \\
\text { "Maria não falou muito" }\end{array}$ & $\begin{array}{l}\text { [Italiano] } \\
\text { a) Non me l'a ancora detto } \\
\text { Não me o tem ainda dito } \\
\text { b) Ancora non me l'a detto } \\
\text { c) *Non ancora me l'a detto } \\
\text { "(Ele) não me disse (isso) ainda" }\end{array}$ \\
\hline
\end{tabular}


Em segundo lugar, os marcadores negativos com caráter adverbial não interferem na distribuição de outros elementos gramaticais, enquanto os marcadores de negação gramaticais interferem na distribuição de outros elementos gramaticais, particularmente no posicionamento de pronomes átonos, conforme ilustrado em (5), com dados extraídos de Zanuttini (1994: 433, 434).

(5) a. Te quisiera ver más.

b. Quisiera no verte más.

c. *Te quisiera no ver más.

Por fim, entre as características que distinguem os marcadores negativos, Zanuttini (1995) afirma que os marcadores negativos gramaticais têm distribuição restrita em relação à morfologia verbal, não ocorrendo com formas do imperativo verdadeiro, mas com uma forma verbal sincrética/supletiva. Tais fatos estão ilustrados no quadro a seguir, com dados extraídos de Zanuttini (1994:120,121) e tradução nossa.

Quadro 4.2 Marcador negativo em sentenças imperativas

\begin{tabular}{|l|l|l|}
\hline $\begin{array}{l}\text { Marcadores negativos com } \\
\text { caráter adverbial }\end{array}$ & \multicolumn{2}{|l|}{ Marcadores negativos com caráter gramatical } \\
\hline Piemontês & Italiano & \\
Parla! (2s) & Imperativo Afirm. & Imperativo Neg. \\
Parla nen! & Telefona! (2s) & *Non telefona! \\
Milanês & Telefonare! & Non telefonare \\
Guarda minga i tosànn! & Telefonate! (2pl) & Non telefonate! \\
Olha-2s não as garotas & Telefoniamo! (1pl) & Non telefoniamo! \\
& & \\
\hline
\end{tabular}

Observando as três diferenças entre os marcadores de negação, Zanuttini (1995) demonstra que existe evidência de que os marcadores de negação pré-verbais nas línguas românicas são elementos da morfossintaxe sentencial. Assim, esses marcadores diferenciam-se dos marcadores pós-verbais, morfossintaticamente autônomos, com distribuição semelhante à dos advérbios.

Zanuttini (1997) analisa a posição dos marcadores negativos com relação à posição do verbo e de advérbios em TP e AspP, seguindo a hierarquia de advérbios 
de Cinque (1999, citado pela autora). Nesse sentido, os marcadores negativos apresentam diferentes propriedades de acordo com a posição em que ocorrem na sentença. E, com isso, a autora propõe quatro posições, ao menos, para a ocorrência dos marcadores negativos (cf. (8)). Para tanto toma por base as seguintes considerações, extraídas de estudo prévio de sua autoria: ${ }^{52}$.

I represent the negative markers (..) as occurring in the specifier of a projection labeled NegP. Reserving the label NegP-1 for the projection headed by the pre-verbal negative markers that by itself can negate a clause, I label the other projections hosting post-verbal negative markers NegP-2, $\mathrm{NegP}-3$, and NegP-4, increasing the number as I move lower in the structure. I therefore conclude that not only is it impossible to talk about one structural position for negative markers in Romance, but also it is not correct to talk about two structural positions only, one preceding and one following Infl (cf. Zanuttini 1991). Rather, the negative markers that follow the finite verb can occur in a range of structural positions, the choice among which is determined within a single language. (ZANUTTINI 1997:114)

Zanuttini (1997:114) apresenta a estrutura proposta, relativamente aos marcadores NegP-2, NegP-3 e NegP-4.

(6)

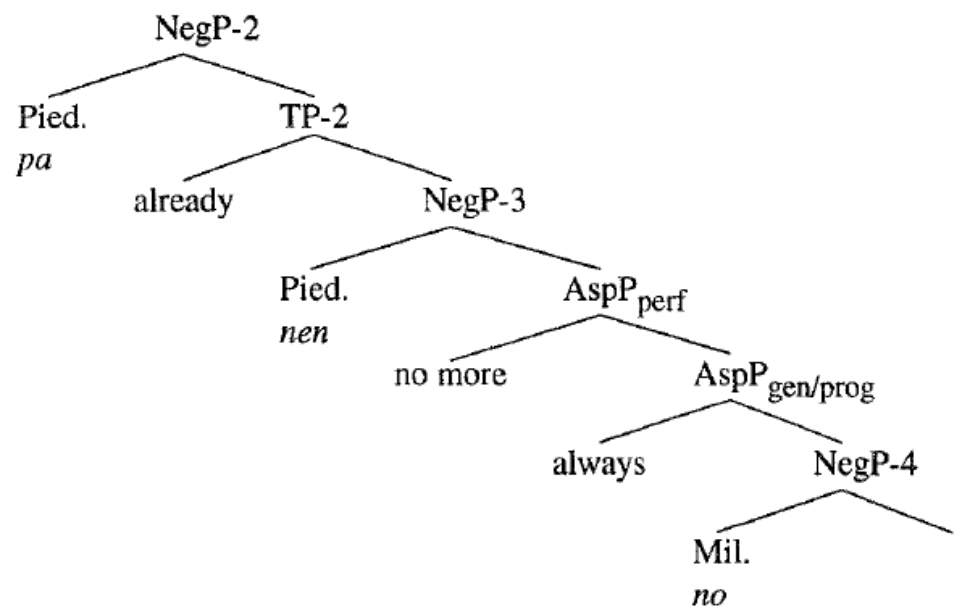

52 "Represento os marcadores negativos na posição de especificador de uma projeção rotulada NegP. Ao reservar o rótulo NegP-1 para a projeção que tem como núcleo marcadores negativos pré-verbais que, por si só pode negar uma oração, eu rotulo as outras projeções que hospedam marcadores negativos pósverbais como NegP-2, NegP-3, e NegP-4, aumentando o número à medida que é deslocado para baixo na estrutura. Concluo, portanto, que não só é impossível falar em uma posição estrutura para marcadores negativos em línguas Românicas, como também não é correto falar sobre duas posições estruturais somente, uma precedendo e uma seguindo Infl (Zanuttini 1991). Antes, marcadores negativos que se seguem ao verbo finito podem ocorrer em uma gama de posições estruturais, sendo a escolha entre elas determinada em cada língua." (ZANUTTINI 1997:114) 
A proposta de Zanuttini $(1995 ; 1997)$ são importantes no que se refere às características que distinguem os marcadores negativos. Primeiramente, conforme mencionado, os marcadores com características adverbiais não possuem posição fixxa em relação ao verbo, permitindo a interpolação de elementos. Esses marcadores não interferem na distribuição de outros elementos gramaticais, enquanto os marcadores de negação gramaticais interferem na distribuição de outros elementos gramaticais, especialmente no posicionamento de pronomes átonos. Além disso, os marcadores negativos gramaticais têm distribuição restrita em relação à morfologia verbal, não ocorrendo com formas do imperativo verdadeiro, exigindo antes alguma forma sincrética/ supletiva. Como o paradigma verbal imperativo do PB é formado apenas por formas supletivas, não há restrições aos marcadores negativos. As sentenças imperativas podem ocorrer em contextos de negação com as formas verbais com morfologia tanto do indicativo quanto do subjuntivo, o que torna a sintaxe de marcadores de negação préverbais significativa para esse trabalho na articulação com os marcadores pós-verbais. Antes de passar a essa discussão, retomamos a discussão em torno das restrições à negação em sentenças de imperativo verdadeiro.

\subsection{Restrições à negação em sentenças com imperativo verdadeiro}

\subsubsection{A análise de Rivero (1994)}

O estudo de Rivero (1994) propõe uma explicação para a impossibilidade de negar a forma do imperativo verdadeiro em línguas da Classe I, em termos de condições estruturais relacionadas ao movimento do verbo. Na análise, a agramaticalidade da sentença com negação pré-verbal diante de verbos com forma própria do imperativo ocorre por uma restrição ao movimento do verbo no imperativo para a categoria C. A autora parte do pressuposto de que o núcleo funcional $\mathrm{C}^{\circ}$ é responsável pela força ilocucionária da sentença, abrigando, portanto, o traço imperativo. O verbo imperativo, nas construções em que apresenta a morfologia especializada (forma verdadeira), deve sofrer checagem através do movimento para a posição $\mathrm{C}^{\circ}$.

A impossibilidade da negação em posição anterior ao verbo flexionado na forma verdadeira do imperativo seria, de acordo com a autora, consequência de um efeito de 
minimalidade ${ }^{53}$ imposto pela presença do marcador negativo, que bloquearia o movimento do verbo para $\mathrm{C}^{\circ}$. A estrutura a seguir demonstra a restrição de negação para as sentenças com imperativo verdadeiro de línguas como italiano e espanhol, em que a partícula negativa, sendo núcleo da categoria NegP, localizada entre o CP e o TP, impede o movimento do $\mathrm{V}$ para $\mathrm{C}$ através de $\mathrm{T}$, por violar um requisito de minimalidade.

(Espanhol)

(Rivero 1994:91)

b.

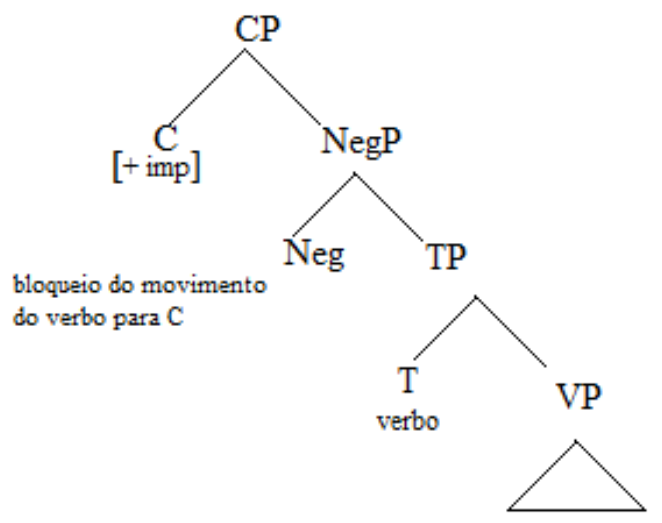

Ao contrário das sentenças com a forma verdadeira, a forma supletiva em sentenças imperativas é permitida pelo fato de que realizam apenas um movimento mais baixo, para a categoria $\mathrm{I}(=\mathrm{T})$, não necessitando realizar movimento para a categoria $\mathrm{C}$. A interpretação do imperativo nessas sentenças com a forma supletiva, de acordo com a autora, é feita através da pragmática. Essa afirmação pode levar a uma generalização de que as línguas que não possuem imperativo verdadeiro não possuem construções formalmente imperativas.

Tratando das línguas da Classe II, como o búlgaro e o servo-croata, que possuem formas exclusivas de imperativo, mas admitem que sejam negadas, Rivero (1994) desenvolve seu argumento no sentido de afirmar que, nessas línguas, a força ilocucionária está codificada no IP (não em CP), mediante a presença de um traço forte

${ }^{53}$ Dessa forma o marcador negativo se torna uma barreira para o movimento do verbo. De acordo com Roberts $(1997,226)$, a barreira por minimalidade é definida da seguinte forma: $\beta$ é uma barreira por minimalidade para $\alpha$ se, e somente se: $\beta$ é um X' (diferente de I'); $\beta$ domina $\alpha$; e o núcleo de $\beta$ é lexical. 
imperativo no núcleo I. Dessa forma, o CP nessas línguas não é uma categoria codificadora desse ato ilocucionário. Essa propriedade interage com o fato de que, nessas línguas, os clíticos são licenciados no domínio de CP (Wackernagel). Sendo o CP uma projeção que acolhe clíticos pronominais, $\mathrm{C}$ nessas línguas é marcado para o licenciamento de um traço $\mathrm{D}$, mediante o movimento de $\mathrm{V}$ para $\mathrm{C}$ (como uma exigência de PF). Nesse sentido, a marcação fixa de C para força ilocucionária seria incompatível com o movimento de $\mathrm{V}$ para cumprir as exigências de licenciamento do clítico, que não estão sujeitas à força ilocucionária. Dessa forma, o movimento de $\mathrm{V}$ para $\mathrm{C}$ não licencia o traço (forte) de imperativo, mas possibilita a manifestação do clítico, por exigência de PF.

4.4.2 Força ilocucionária, escopo e negação: o problema semântico apresentado por Han (1999)

O estudo de Han (1999) parte de uma crítica à análise de Rivero (1994), considerando a hipótese de que marcadores negativos em línguas como o italiano e o espanhol têm caráter clítico (o mesmo se aplicaria ao português). Sendo um elemento clítico, a negação constituiria um núcleo complexo com o verbo e não deveria impedir o seu movimento para $\mathrm{C}^{\circ}$, passando sobre NegP. O caráter clítico da negação nessas línguas pode ser confirmado pelo fato de que nenhum outro elemento que também seja clítico pode interromper a ligação estrita do verbo com a negação conforme (8a): a interrupção da adjacência entre negação e verbo por um pronome (8b) torna a sentença agramatical.

(8) a. No dar le el libro

Neg give.Inf him the book

(Espanhol)

'Don't give him the book!'

'Não dê o livro a ele'

b. *No le dar el libro!

Neg him give.Inf the book

'Don't give him the book!'

'Não dê o livro a ele'

(HAN 1999:54) 
Um argumento adicional trazido por Han (1999) é a possibilidade de haver movimento do verbo para $\mathrm{C}^{\circ}$, em sentenças negativas, incluindo-se a negação, nos contextos de Aux-to-Comp, conforme discutido em Rizzi (1982, citado pela autora):
a. Avendo Gianni fatto questo, ...
Having Gianni done this
'Tendo Gianni feito isso'
b. Non avendo Gianni fatto questo...
Neg having Gianni done this
'Não tendo Gianni feito isso'

(Italiano)

(HAN 1999:30)

Assumindo que, em (9b), o movimento do auxiliar para C indica o caráter clítico da negação, Han (1999) alega que a ausência de restrição nesse caso se deve ao fato de o núcleo $\mathrm{C}^{\circ}$ não ser marcado para o traço ilocucionário. Dessa forma, não ocorre o efeito do escopo da negação sobre o traço ilocucionário em $\mathrm{C}^{\circ}$.

Han (1999) propõe então que o movimento do verbo para $\mathrm{C}^{\circ}$ não é bloqueado pela sintaxe, mas pela semântica, como consequência do efeito do escopo da negação sobre a força ilocucionária da sentença. Considerando a ausência do imperativo em oração encaixada como evidência, Han (1999) assume que operador ilocucionário está situado em $\mathrm{C}$, havendo um requerimento de interface que impede que a força ilocucionária imperativa esteja sob o escopo da negação. Assumindo-se que, por razões sintáticas, o verbo deve mover-se para a projeção C, para checagem do traço imperativo, e que a negação funciona como um clítico, o movimento do verbo de $\mathrm{V}$ para $\mathrm{C}$ passa pela projeção NEG, criando uma configuração em que a negação se cliticiza a $\mathrm{V}$ passa a ter escopo sobre o traço imperativo, causando uma representação ilegítima em LF.

Com isso, a autora defende que esse movimento impõe um requerimento de interface de que a negação nunca tenha escopo sobre a força ilocucionária. Na interpretação de uma sentença imperativa negativa como (10), a força ilocucionária toma escopo sobre a negação e não o contrário. Diferentemente, na presença da forma verbal supletiva, no subjuntivo, o traço ilocucionário em $\mathrm{C}$ é verificado sem movimento de $\mathrm{V}$ para $\mathrm{C}$.

$$
\begin{aligned}
& \text { *Mi grapse to! } \\
& \text { Neg write-2sg.Imp it } \\
& \text { 'Don't write it!' } \\
& \text { 'Não escreva isso!' }
\end{aligned}
$$


Segundo Han, é justamente isso que ocorre quando o complexo [neg + V] se move para $\mathrm{C}^{\circ}$ : o movimento coloca o traço imperativo de $\mathrm{C}^{\circ}$ e a negação (sob ccomando de C) no mesmo domínio, gerando uma leitura proibida. Para justificar essa restrição, recorre aos dados em (11), em que contrasta a sentença imperativa raiz com polaridade negativa, com uma estrutura em que o conteúdo proposicional está expresso em uma oração encaixada a um verbo do tipo causativo/diretivo, com a negação realizada ora na oração encaixada, ora na oração matriz, demonstrando que existe equivalência de significado com a primeira, mas não com a segunda.
a. Don't call!
'Não ligue!'
b. $\quad \approx$ It is required that you not call
'É necessário que você não ligue'
c. $\quad \neq$ It is not required that you call.
'Não é necessário que você ligue.'

(HAN 1999: 40)

Em relação às línguas da Classe II, que não manifestam restrição à negação do imperativo (verdadeiro), Han (1999) reconhece que seriam contra-exemplos a sua análise, caso fosse assumido um tratamento uniforme para a força ilocucionária como uma propriedade de $\mathrm{C}^{\circ}$. A solução para esse dilema é assumir a análise de Rivero; Terzi (1995) para essas línguas, em que o V não se move para C (pelo fato de haver clíticos pré-verbais em contextos imperativos em que o verbo não está na primeira posição). No entanto, diferentemente de Rivero; Terzi (1995), Han (1999) mantém o requisito de que operador ilocucionário está situado em C, postulando o movimento de V para C em LF, o que não afeta a negação, já que a cliticização é um fenômeno de PF.

Conforme observado em Ferreira Júnior; Salles (2016), em relação ao dado envolvendo movimento "Aux-to-Comp" referido por Han (1999) para confirmar a hipótese de que a impossibilidade de negar o imperativo (verdadeiro) decorre do efeito do escopo da negação sobre a força ilocucionária, e não do efeito de minimalidade imposto por Neg ao movimento de V para C, conforme proposto por Rivero (1994), caberia considerar o fato de que existem estruturas "Aux-to-Comp" com polaridade 
negativa, em que é possível confirmar que o núcleo $\mathrm{C}^{\circ}$ é marcado para um traço de modalidade. É o caso do movimento em estruturas infinitivas selecionadas por verbos atitude proposicional, como acreditar, que podem selecionar tanto um CP realis quanto um CP irrealis, sendo esse traço determinado pelo núcleo $\mathrm{C}$, conforme ilustrado a seguir em que a estrutura encaixada é ambígua para as duas interpretações:

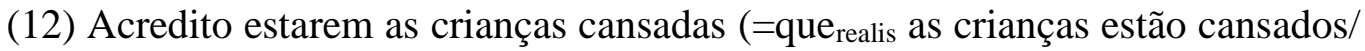
que $_{\text {irrealis }}$ as crianças estejam cansados)

Nessas estruturas, como nas estruturas com o verbos diretivos, a negação impõe restrições à interpretação ao conteúdo proposicional da oração encaixada, indicando efeito semelhante ao que está sendo associado às construções, que ficaria sem explicação nos termos propostos pela autora.

(13) a. As crianças não estão cansadas.

b. $\quad \approx$ Acredito não estarem as crianças cansadas.

c. $\quad \neq$ Não acredito estarem as crianças cansadas (=que $e_{\text {realis }}$ as crianças estão cansadas/ que irrealis $_{\text {as crianças estejam cansadas) }}$

Dessa forma, adotando-se o argumento de Han (1999) baseado no efeito do escopo da negação sobre a força ilocucionária, caberia indagar por que o movimento não bloqueia o efeito do escopo em relação ao dado em (15), em que, nos mesmos termos, existe movimento de $\mathrm{V}$ para $\mathrm{C}$.

Neste trabalho, tendo em vista o modelo de análise proposto no Capítulo 3 para as orações imperativas, em que as propriedades ilocucionárias estão codificadas no domínio de CP, retemos a proposta de Rivero (1994) e de Rivero; Terzi (1995) para o contraste entre as línguas da Classe I e da Classe II em termos do movimento de V para $\mathrm{C}^{54}$.

\footnotetext{
${ }^{54}$ Referimos o leitor ao estudo de Cavalcante (2010), que questiona a análise baseada no movimento do verbo, em favor de uma proposta em que a restrição à negação do imperativo verdadeiro resulta de uma exigência no nível de PF de adjacência entre o verbo e morfema imperativo abstrato em C (nos termos de BOŠKOVIĆ 2004, citado pelo autor). Para tanto, questiona as análises de Rivero (1994) e Han (1999) baseadas no movimento de $\mathrm{V}$ para $\mathrm{C}$, invocando dados em que advérbios negativos como NUNCA, realizados por hipótese no especificador de NegP, desencadeiam o mesmo efeito de bloquear o imperativo verdadeiro, embora não criem o efeito de minimalidade postulado nas análises prévias, por sua posição estrutural. Diferentemente, para o argumento baseado na exigência de adjacência no nível de PF, o item NUNCA produz efeito de interveniência desejado, conforme prevê a análise. Nosso entendimento é o de
} 
Em relação ao $\mathrm{PB}$, sabemos que as formas do imperativo não impõem restrição à negação, conforme ilustrado na seção inicial deste Capítulo. Vários estudos têm se dedicado às estruturas imperativas no PB. Além da descrição e análise dos aspectos que envolvem o uso variável das formas do indicativo e do subjuntivo nessas estruturas, e das variáveis que as condicionam, no quadro teórico da sociolinguística laboviana, citados no Capítulo 1, existem estudos no quadro teórico gerativista, particularmente em relação ao problema colocado pelos itens de polaridade (negativa).

Nesse sentido, partindo da análise proposta no Capítulo 3, verificamos que a principal questão relativa às estruturas de imperativo negativo no PB é a possibilidade de negar as formas disponíveis. Tendo analisado sua manifestação no Capítulo 1, concluímos pela hipótese de que o PB não manifesta a forma do imperativo verdadeiro, um fenômeno que interage com um conjunto de características morfossintáticas, amplamente discutidas na literatura, entre elas a reanálise do sistema pronominal (com a gramaticalização de você), a neutralização das formas verbais finitas de $2^{\mathrm{a}}$ e $3^{\mathrm{a}}$ pessoa, a sintaxe dos clíticos, a ausência do movimento do verbo para $\mathrm{C}$, a sintaxe da negação, a neutralização das formas do indicativo e do subjuntivos em orações completivas selecionadas por verbos volitivos e de atitude proposicional.

Em relação à proposta original de Rivero (1994), em que a sintaxe do imperativo verdadeiro é associada ao movimento de $\mathrm{V}$ para $\mathrm{C}$, a inexistência desse movimento no PB constitui um aspecto relevante. A perda do movimento para $\mathrm{C}^{\circ}$ é também identificada em outras construções do PB, como as sentenças declarativas e as interrogativas (cf. Torres Morais 1993; Lopes Rossi 1993; Figueiredo e Silva 1996; Kato; Mioto 2005). Tais propriedades podem ser ainda relacionadas à sintaxe da negação, que manifesta os padrões de negação pré-verbal, pós-verbal e a dupla negação. Essas questões serão retomadas na seção a seguir.

Conforme discutido no Capítulo 3, a hipótese da ausência de movimento para C em sentenças com a forma supletiva também é compartilhada por Isac (2015). A autora afirma que verbos imperativos com a forma verdadeira checam traços no núcleo Se (Speech Event), marcado para o traço do destinatário (e portanto para a $2^{\mathrm{a}}$ pessoa), enquanto verbos imperativos com a forma supletiva realizam a checagem de traços em F, categoria c-comandada por Mod, que detém traços phi e de Caso. Nesse sentido, compartilhamos a compreensão de que as diferenças entre o PE e o PB, em relação à

que o efeito de minimalidade pode ser elaborado em termos da presença de uma morfema abstrato na projeção que hospeda o item NUNCA, produzindo o efeito desejado para a análise baseada na minimalidade. 
possibilidade de negar estruturas imperativas, poderiam ser explicadas a partir da hipótese de que verbos com a forma verdadeira e com a forma supletiva checam seus traços em categorias diferentes. Entendemos, ainda, conforme Isac (2015), que a diferença na checagem dos traços gera interpretações diferentes, o que gera um efeito de polidez em contextos de imperativo supletivo (ISAC 2015:186).

\subsection{Os marcadores negativos no PB}

Nesta seção, retomamos o comportamento das duas formas de negação sentencial apresentadas por Zanuttini (1995), e referidas na seção 4.3, a fim de verificar se a tipologia por ela proposta pode ser aplicada ao $\mathrm{PB}$, em relação aos tipos e estratégias de negação encontradas nessa língua.

Conforme é possível identificar na literatura (cf. Mioto, 1991; Namiuti 2008; Biberauer;Cyrino, 2009 entre outros), há evidência de que a negação pré-verbal manifesta o estatuto de marcador gramatical, ocorrendo em posição fixa em relação ao verbo, já que apenas pronomes átonos podem intervir entre a negação e o verbo.

(14) Maria não pode te ajudar.

(15) Maria pode não te ajudar.

(MIOTO 1991:63)

Em (14) o não tem escopo sobre 'pode te ajudar' e em (15) sobre 'te ajudar'. Segundo Mioto (1991), o resultado da subida do clítico em (14) gera em (16a) uma interpretação marginal, mas, se houver a subida do clítico em (15), a interpretação da sentença é ruim. A sentença em (16b) demonstra ainda a impossibilidade de haver interpolação entre o clítico e o verbo: ${ }^{55}$

(16) a. *? Maria não te pode ajudar.

b. * Maria te não pode ajudar.

(MIOTO 1991:63)

\footnotetext{
55 A interpolação do clítico entre a negação e o verbo já ocorreu no português. As primeiras ocorrências de interpolação da negação nesses contextos são encontradas consistentemente em textos do século 13, 14, 15, e são frequentes nos séculos 16 e 17 (cf. MATTOS \& SILVA, R. V. 1993; NAMIUTI, C. Aspectos da história gramatical do português. Interpolação, negação e mudança. UNICAMP. CampinalSP, 2008).
} 
No PB vernacular, são ainda encontradas duas outras formas de apresentação da negação, conforme ilustrado a seguir, em exemplo nosso.

(17) a. João não abriu a caixa não .

b. João abriu não.

Comparando-se as duas formas em (17) às apresentadas por Zanuttini (1995), podemos supor que o PB apresenta uma negação de caráter adverbial e outra que possui características de categoria gramatical, identificando-se assim as três estratégias de sentenças negativas.

A relação entre os diferentes marcadores negativos é analisada na literatura de formas diversas. Entre as possibilidades de manifestação da negação em relação ao verbo, a construção Neg-V-Neg no PB é abordada em diferentes análises. Nesse sentido, Seixas et al. (2012) apresentam algumas hipóteses formuladas para a formação da dupla-negação.

1. Essa estrutura surgiu através do contato do português com línguas africanas, caracterizando-se como um caso de "influência de substrato" Hipótese do contato (HOLM, 1988; BERNINI \& RAMAT, 1996; BAXTER \& LUCCHESI, 1997; BAXTER, 1998). 2. Essa estrutura é resultado do enfraquecimento do primeiro não, que fez com que aparecesse o segundo hipótese do enfraquecimento (SALLES FILHO, 1980; FURTADO DA CUNHA, 1996). 3. Essa estrutura é resultado de mudança paramétrica (GONÇALVES, 1994; MARTINS, 1997) 4. Essa estrutura é resultado da reanálise do item não. Este elemento teria passado de enunciado completo, para constituinte da oração - hipótese proposta por Alkmim (2001). Para a autora, o segundo não era um elemento que não fazia parte da oração. Posteriormente, foi incorporado (gramaticalizado), perdendo na fala, a pausa, e na escrita, a vírgula. 5. Essa estrutura, do ponto de vista sintático, apresenta uma partícula não final com a mesma realização fonológica de duas categorias distintas (não2 e não3), que ocupariam diferentes posições na estrutura sentencial, e do ponto de vista semântico, enquanto nãol desencadeia uma negação proposicional, não2 e não3 são descritos como marcadores de negação pressuposicional - hipótese proposta por Cyrino \& Biberauer (2009). (Seixas et al. 2012: 269-270)

Para o estudo a respeito dos marcadores negativos no $\mathrm{PB}$, vamos começar com a análise do marcador negativo pré-verbal. Na análise, adotamos o posicionamento de Ramos (2006), que demonstra o enfraquecimento do marcador negativo pré-verbal, e a manifestação da forma num como uma variante de não. Assumimos também a proposta de Vitral (2006) segundo a qual o enfraquecimento do marcador pré-verbal no PB tem relação com o Ciclo de Jespersen para o surgimento dos marcadores negativos. 
Duas diferentes possibilidades de negação surgem inicialmente com o enfraquecimento do marcador negativo pré-verbal. Conforme Zanuttini (1995), esse enfraquecimento é visto na passagem do primeiro para o segundo estágio do Ciclo de Jespersen. O enfraquecimento gera repercussões também no nível fonético, o que, no PB, corresponde à realização de 'num' em contexto pré-verbal (cf. Ramos 2006). Ramos ainda apresenta a hipótese de que a natureza fraca do marcador negativo préverbal no PB não permite que a sentença seja negada independentemente. Nesse sentido, é necessária a ocorrência de outro marcador negativo para que a negação da sentença ocorra, gerando a dupla negação [Não-V-não]. Ainda há a possibilidade de que a negação pós-verbal [V-Não] negue a sentença independentemente.

4.5.1 O estatuto clítico do marcador negativo pré-verbal no dialeto mineiro: a análise de Ramos (2002; 2006)

O estudo de Ramos $(2002 ; 2006)$ examina dados de fala oral coletados na região Sudeste e Centro-Oeste, mostrando a ocorrência das variantes num e não. A análise parte da hipótese de que o marcador negativo pré-verbal é uma categoria (quase-)clítica, nos termos de Ilari et al. (1991: 131-133), citado pela autora, sendo a ocorrência da forma reduzida num (não>num) uma evidência do processo de gramaticalização que a autora busca investigar.

A autora apresenta quatro fatores que favorecem a ocorrência de num, considerados evidência para seu estatuto clítico:

(18) a. a posição não final na sentença

b. a presença da variante plena "não" na mesma sentença.

c. a posição pré-verbal e

d. contiguidade com $\mathrm{V}$.

(RAMOS 2006:121)

Dessa forma, é agramatical sua realização no contexto da negação pós-verbal.

(19) a. se eu num/não sou formada hoje

b. acredito não/*num 
c. que eu num/não concordava com aquilo *num/não

$(\text { RAMOS 2006:119) })^{56}$

Segundo Ramos (2006), as características em (19) podem ser comparadas com propriedades exibidas por clíticos pronominais, extraídas de Kayne (1976: 84110), citado pela autora, sendo essas: (i) a impossibilidade de algum elemento intervir entre o clítico e o verbo, exceto outros clíticos (José não/num é inteligente/ José não/num me viu), (ii) o clítico não poder ser modificado, não aceitar acento contrastivo, não poder ser coordenado (A: -Você comprou o carro?/B: - Não/*num) e (iii) a ordem clítico-V ser fixa José não/num me viu/*José me não/num viu). ${ }^{57}$

No sentido de verificar a interferência dos tipos de elementos que aparecem à esquerda ou à direita, a autora chega à conclusão de que o tipo de elemento à esquerda (Sujeito NP/ pausa/ outros) não é significativo para a distribuição de num: "[e]ste resultado constitui indicação de que a forma num se liga a elementos à direita, e não aos elementos à esquerda, pois mesmo após pausa ambos os itens ocorrem." (p. 123)

Segue-se então a verificação do efeito de elementos à direita, sendo confirmada a significância do fator, que aponta para a cliticização à direita a verbo auxiliar e verbo simples, confirmada pela ausência quase categórica de num antes de pausa, "uma vez que ausência de pausa constitui uma evidência de não autonomia fonológica de num" (p. 124).

Tabela 4.1. Distribuição de num de acordo com elemento na posição seguinte

\begin{tabular}{|l|l|l|l|}
\hline Posição Seguinte & Ocorrência & Frequência & Probabilidade \\
\hline Verbo auxiliar & $102 / 168$ & $61 \%$ & .76 \\
\hline Verbo principal & $227 / 384$ & $58 \%$ & .75 \\
\hline Outros elementos & $11 / 30$ & $37 \%$ & .51 \\
\hline Pausa & $4 / 180$ & $2 \%$ & .03 \\
\hline
\end{tabular}

(Ramos 2006:124)

Foi constatada também maior frequência de num em orações principais/ raiz, do que em subordinadas, o que está de acordo com as previsões quanto à

\footnotetext{
56 Os dados agramaticais não estão presentes nos exemplos apresentados por Ramos (2006). e são utilizados aqui apenas para demonstrar didaticamente o contraste entre as sentenças. Adaptamos para as propriedades citadas os dados fornecidos pela autora para ilustrar as estruturas Neg-V, V-Neg, Neg-V$\mathrm{Neg}$.

57 Os dados não constam do texto da autora, e foram inseridos com base em Vitral (1999).
} 
possibilidade de que essa forma esteja associada a um processo de mudança.

Na busca de confirmar a hipótese da mudança linguística, a autora recorre à variável tempo aparente. Uma das evidências da ocorrência da gramaticalização da forma pré-verbal num é a maior incidência de realizações dessa forma de acordo com o extrato etário dos jovens, havendo um efeito gradual em relação aos demais extratos.

Tabela 4.2 Distribuição de num de acordo com grupo etário do informante

\begin{tabular}{|l|l|l|l|}
\hline Grupo Etário & Ocorrências & Frequência & Probabilidade \\
\hline Jovens & $139 / 165$ & $84 \%$ & .70 \\
\hline Medianos & $120 / 237$ & $51 \%$ & .48 \\
\hline Velhos & $85 / 225$ & $38 \%$ & .32 \\
\hline
\end{tabular}

(Ramos 2006:126)

Consta ainda da investigação a manifestação de num em relação a itens negativos. A pergunta é: “Até que ponto a presença da segunda negação favorece o item num pré-verbal?"'(p.128) Observou-se que quantificadores negativos pospostos, como ninguém, favorecem num, embora os dados sejam reduzidos, como é de se esperar.

Tabela 4.3 Distribuição de não e num em frases da forma [...Neg... QNeg...]

\begin{tabular}{|l|l|l|}
\hline Forma realizada & Ocorrências & Frequência \\
\hline Não & 21 & $36 \%$ \\
\hline Num & 37 & $64 \%$ \\
\hline Total & 58 & $100 \%$ \\
\hline
\end{tabular}

(Ramos 2006:128)

Verificou-se também a incidência do marcador negativo num, em relação a não, com o marcador negativo tônico pós-verbal não. A hipótese da autora é a seguinte: "[s]e a presença da "segunda" negação compensar a primeira, teremos um perfil crescente de num nas negativas simples e presença categórica de num nas negativas duplas." Enquanto num na negativa simples revelou decréscimo, não se confirmou seu uso categórico na negativa dupla. No entanto, assumindo-se a negativa simples e a negativa dupla como etapas de um mesmo processo de mudança (conforme o ciclo de Jespersen), é de se esperar que a forma simples esteja decaindo. É o que se verifica nos dados quantitativos, conforme a tabela 4.2. 
A autora conclui que os resultados apontam para uma situação de mudança linguística em processo, conforme o esquema a seguir:

(20) $[\mathrm{NÃO}>\mathrm{NUM}]$

[NÃO V NÃO] > [NUM V NÃO]

Ramos (2006) observa que as conclusões são preliminares, havendo necessidade de ampliação da amostra e a investigação de outras variáveis, particularmente a relação entre as formas variantes num/não (observada nas estruturas Neg-V e Neg-V-Neg), e a ocorrência das estruturas V-Neg, como em Ele tomava banho não (cf. RONCARATTI 1996:103), citada pela autora.

Diante dessa observação, acrescentamos outro trabalho que analisa o enfraquecimento da negação pré-verbal, que é o de Furtado da Cunha (1996). Neste trabalho, a autora considera a existência do marcador negativo pós-verbal na estrutura de dupla negação como reforço. A pesquisa desenvolvida apresenta dados do dialeto do Rio Grande do Norte. Em seu trabalho, a autora propõe que a redução fonológica do marcador negativo pré-verbal de 'não' para 'num' justifica a existência de um marcador negativo pós-verbal como reforçador da negação em estruturas com dupla negação.

Em sua pesquisa, os resultados obtidos apresentam 88,9\% de estruturas com negação pré-verbal [Neg-V], 10,4\% de estruturas com dupla negação [Neg V Não] e 0,3\% de estruturas com negação pós-verbal [V Não]. Os dados encontrados na fala perfazem um total de 1505 ocorrências. Ao comparar os dados obtidos com textos escritos, a autora constata que entre as três estruturas, apenas a primeira $[\mathrm{Neg}-\mathrm{V}]$ é realizada na escrita.

A inexistência de sentenças com dupla negação na escrita é justificada pela autora em razão de que na escrita não ocorre redução fonética do item negativo e, por consequência, não ocorre o enfraquecimento do marcador pré-verbal. Esse fato justifica também, segundo essa análise, que a reduplicação não ocorra para efeito de reforço ou ênfase, fenômeno típico da fala. Retomando o processo dos marcadores negativos na fala, a autora observa que o enfraquecimento nos marcadores negativos pré-verbais encontra motivação no discurso falado rapidamente. A pronúncia do 'não' tônico sofre enfraquecimento e redução para o 'num' átono, ou até mesmo para uma nasalização. Esse enfraquecimento gera o processo de reforço da negação por meio da inserção de um novo marcador negativo na posição adverbial da sentença. 
4.5.2. A projeção sintática do marcador de negação no PB no quadro teórico minimalista: a análise de Vitral (1999; 2006)

Vitral (1999; 2006) apresenta uma hipótese a respeito da projeção sintática da negação no PB, partindo da análise de itens de polaridade negativa (como anybody, anything, anywhere) e quantificadores/itens negativos (como nobody, nothing) em inglês. Observa que, no $\mathrm{PB}$, quantificadores/itens negativos $(\mathrm{N})$ ninguém e nada manifestam o fenômeno da concordância negativa, que prevê a presença da partícula negativa, quando ocorrem em posição pós-verbal, mas a dispensam quando em posição pré-verbal, conforme ilustrado a seguir, com dados do autor (p. 136):

(21) a. Ninguém (*não) conseguiu passar no vestibular.

b. Manuel *(não) viu ninguém no cinema.

Assumindo que o marcador negativo é núcleo de uma categoria funcional, o autor propõe, no quadro da teoria de checagem de traços, que um marcador negativo deve c-comandar um núcleo lexical na sintaxe visível. Nesse sentido, na presença de uma partícula negativa ou de um item $\mathrm{N}$ (ninguém, nada, nunca) com traço formal [+Neg] na numeração, esse traço formal é responsável pelo surgimento de uma categoria que também é representada por esse traço, que é forte. $\mathrm{O}$ marcador negativo será inserido na derivação por meio do MERGE em Neg, com a respectiva checagem do traço [+Neg].

Para Vitral (2006), a hipótese apresentada explica a possibilidade de itens $\mathrm{N}$ ocorrerem em posição pré-verbal, conforme ilustrado em (22), extraído de Vitral (2006: 140), mediante a hipótese de que o núcleo NEG pode ser nulo.

(22) a. José nunca/jamais ganhará na loto.

b. Nunca/ Jamais o Pedro diria uma coisa dessas.

c. Pedro nada comprará naquela loja.

d. Nada a Maria devolveu ao Pedro.

e. Nada foi feito pelo Pedro.

f. Ninguém sai de casa com um tempo desse!

g. ?NINGUÉM o José encontrou a feata. 
Vitral (2006) propõe que a derivação dessas sentenças ocorra da seguinte maneira: itens $\mathrm{N}$ como 'nada' e 'ninguém' na posição de objeto ou argumento externo e 'nunca' e 'jamais' numa posição adverbial adjunta a VP realizam deslocamento na derivação por meio de MOVE, podendo então ocupar a posição de especificador de $\mathrm{NegP}$ ou transitar por ela. Essas duas operações permitem checar o traço [+Neg]. Se o deslocamento dos itens $\mathrm{N}$ tiver lugar na sintaxe visível, a inserção do marcador negativo 'não' não será necessária. Caso o marcador negativo seja inserido por meio de MERGE, o movimento dos itens $\mathrm{N}$ não precisa ocorrer, e esses itens permanecem nas posições previstas.

O autor estende sua hipótese para línguas com marcadores negativos em posição final. Para o autor, nessas línguas, os marcadores negativos ocupam a posição de adjuntos de VP antes do Spell-Out e realizam movimento para a checagem de Neg na sintaxe encoberta. Conclui que o traço Neg é fraco nessas línguas. Para desenvolver o significado teórico do estatuto Forte/Fraco de Neg, Vitral (2006) recorre ao ciclo da negação de Jespersen. Assim, considera que elementos negativos pré-verbais sofrem redução e passam a ser incorporados ao verbo. Para que haja reforço da negação na sentença, surgem outros elementos em posição pós-verbal. Esses elementos diacronicamente recebem valor negativo. Assim, assume que o ciclo de Jespersen pode ser entendido como fases do processo de gramaticalização.

$\mathrm{Na}$ análise de Vitral (2006), é crucial a hipótese de que o marcador negativo no PB é um clítico, o que confirma seu estatuto sintático de núcleo da projeção NegP. Essa análise, por sua vez, é fortemente apoiada no estudo de Ramos (2006) sobre a ocorrência do marcador num em variação com não, no dialeto mineiro.

A seguir apresentamos o estudo de Biberauer; Cyrino (2009), que examina a coexistência de diferentes tipos de marcadores negativos no PB, apontando para a possibilidade de que um processo de mudança linguística esteja em curso, que consiste na passagem de um padrão pré-verbal para um pós-verbal, exibindo como uma fase intermediária, com a coocorrência da dupla negação. 
4.5.3 Características inovadoras da negação no PB: a dupla negação e a negação pós-verbal na análise de Biberauer; Cyrino (2009)

Biberauer; Cyrino (2009) apresentam a dupla negação como uma estrutura que possui dois itens negativos, sendo que um item funciona como um elemento de concordância (Agree), que geraria necessariamente uma interpretação reforçativa. Para definir a análise, as autoras adotam a categoria PolP, para explicar a derivação de estruturas com dupla negação. Essa categoria estaria presente na derivação entre $\mathrm{CP}$ e TP e seria preenchida apenas em casos em que houvesse ênfase pressuposicional.

(23) Q: O João comprou a casa?

A: Ele disse que [PolP não2]

Negativa simples: Ele disse que [PolP [TP num/ não1comprou]]

Negativa enfática: Ele disse que [PolP [TP num/ não1comprou] não2 <TP $>$ ]

(BIBERAUER; CYRINO 2009: 60)

As autoras consideram que a origem da estrutura de dupla negação é explicada a partir do negador pró-frase, que nas línguas românicas ocorre em PolP:

(24) a. Acho que sim/ não.

b. Creo que sí/ no (espanhol)

c. Penso di sì/ non (italiano)

(25) a. *Ich glaube dass/ vonnein (alemão) 'eu acredito que de não'

b. *Ik denk dat/ vannee (holandês) 'eu acho que de não'

(africâner)

c. *Ek dink dat/ vannee 'eu acho que de não'

(BIBERAUER; CYRINO 2009:61)

Nesse sentido, as estruturas com dupla negação não estariam restritas a contextos responsivos, podendo veicular informação nova, diferentemente do que as autoras propõem para a negação pós-verbal. Por esse motivo, Biberauer; Cyrino (2009) 
consideram que as estruturas com dupla negação e com negação pós-verbal não representam o mesmo tipo de fenômeno. Além disso, as autoras propõem que os dois marcadores negativos finais podem ser considerados como elementos lexicais distintos, sendo consequentemente representados em posições sintáticas distintas. Assim, definem o marcador negativo pós-verbal da dupla negação como 'não2', e o marcador negativo pós-verbal isolado como 'não3'. Consideram como 'nao1' os marcadores negativos préverbais. Para justificar a distinção entre esses marcadores negativos, as autoras apresentam um conjunto de dados:

(26) Q: Por que você está desesperada? O que aconteceu?

a. A: Eu (num/ não1) tô achando minha gatinha(não2)

b. A: *Tô achando minha gatinha (não3)

(BIBERAUER; CYRINO 2009:63)

Segundo as autoras, diferentemente do 'não3', o 'não2' não está restrito a contextos pressuposicionais. Conforme o exemplo apresentado em (b), a ocorrência do 'não3' na sentença é considerada agramatical. O 'não2' pode ocorrer ainda tanto em sentenças matrizes quanto em encaixadas (a), diferentemente do 'não3', que só é possível em sentenças matrizes, como é possível observar nos exemplos a seguir:

(27) a. Ele disse que ele (num/ não1) comprou a casa (não2).

b. *Ele disse que ele comprou a casa (não3)

(BIBERAUER; CYRINO 2009:64)

Além disso, as autoras apontam que a ocorrência do 'não2' em estruturas com sentenças interrogativas que solicitam respostas do tipo sim-não simples (30a) é gramatical, o que não ocorre com o 'não3', que só ocorre em sentenças interrogativas que tenham ênfase pressuposicional (36c).

(28) a. Você (num/ não1) comprou a casa (não2)? 

b. *Você comprou a casa (não3)? (interrogativa simples)
c. Você comprou a casa não3? (ênfase pressuposicional)

(BIBERAUER; CYRINO 2009:69)

Outro fator que diferencia esses marcadores negativos diz respeito à compatibilidade desses marcadores negativos com itens de Polaridade Negativa. Enquanto o 'não2' é compatível, o 'não3' seria incompatível com esses itens:

(29) O João é rico!

a. O quê? ele (num/ não1) tem um tostão furado!

b. O quê? ele (num/não1) tem um tostão furado (não2)!

c. *O quê? ele tem um tostão furado (não3)!

(BIBERAUER; CYRINO 2009:69)

As autoras apresentam o contraste entre o 'não2' e o 'não3' no que diz respeito à possibilidade de omissão em sentenças. Enquanto o 'não2' pode ser omitido, sem prejuízo para a negação da sentença, caso o 'não3' seja omitido, a sentença passará a ser afirmativa.

(30) a. João (não1) comprou a casa (não2).

b. João (não1) comprou a casa $\emptyset$.

c. João comprou a casa (não3).

d. *João comprou a casa $(\varnothing)$ (considerando-se a sentença como negativa)

(BIBERAUER; CYRINO 2009:69)

Com base nessa hipótese, Biberauer; Cyrino (2009) estabelecem uma diferença entre os marcadores de negação pós-verbais de sentenças com dupla-negação 'neg2' e de sentenças com ocorrência exclusiva de marcadores pós-verbais 'neg3'. Apresentamos, no quadro a seguir, as diferenças de contextos gramaticais entre 'neg2' e 'neg3'. 
Quadro 4.3 - Distribuição dos marcadores negativos no PB por tipos de sentença

\begin{tabular}{|c|c|c|c|}
\hline $\begin{array}{l}\text { Tipo de } \\
\text { sentença }\end{array}$ & NEG-V & NEG-V-NEG & V-NEG \\
\hline Declarativas & $\begin{array}{c}\text { Maria } \\
\text { não/*num viu o } \\
\text { acidente. }\end{array}$ & $\begin{array}{l}\text { Maria não/num viu o } \\
\text { acidente não/*num. }\end{array}$ & Choveu não/*num. \\
\hline Interrogativas & $\begin{array}{l}\text { Você não quer que } \\
\text { eu vá? }\end{array}$ & $\begin{array}{l}\text { Você não quer que eu } \\
\text { vá não? }\end{array}$ & $\begin{array}{l}\text { *Você quer que eu vá } \\
\text { não? }\end{array}$ \\
\hline Encaixadas & $\begin{array}{l}\text { João não quer que } \\
\text { você vá. }\end{array}$ & $\begin{array}{l}\text { João não/num quer } \\
\text { que você vá não/*num }\end{array}$ & $\begin{array}{l}\text { *João } \\
\text { você vá não. }\end{array}$ \\
\hline Imperativas & Não use esse tênis. & $\begin{array}{l}\text { Não usa esse tênis } \\
\text { não. }\end{array}$ & Usa esse tênis não. \\
\hline $\begin{array}{l}\text { Verbos não } \\
\text { finitos }\end{array}$ & $\begin{array}{l}\text { Não fumar faz bem à } \\
\text { saúde. }\end{array}$ & $\begin{array}{l}\text { *Não fumar não, faz } \\
\text { bem à saúde. }\end{array}$ & $\begin{array}{l}\text { *Fumar não, faz bem à } \\
\text { saúde. }\end{array}$ \\
\hline $\begin{array}{l}\text { Coocorrência } \\
\text { com } \\
\text { conjunções } \\
\text { subordinativas }\end{array}$ & $\begin{array}{l}\text { Lamento que você } \\
\text { não possa vir. }\end{array}$ & $\begin{array}{l}\text { *Lamento que você } \\
\text { não possa vir não. }\end{array}$ & $\begin{array}{l}\text { *Lamento que você } \\
\text { possa vir não. }\end{array}$ \\
\hline Tópico & $\begin{array}{ll}\text { Esse tênis } & \text { eu } \\
\text { não/num lavei. } & \end{array}$ & $\begin{array}{l}\text { Esse tênis eu não/num } \\
\text { lavei não }\end{array}$ & *Esse tênis eu lavei não \\
\hline
\end{tabular}

As sentenças apresentadas no quadro demonstram que existem grandes restrições no que diz respeito à ocorrência de 'neg3'. Em contextos de tópico, coocorrência com conjunções subordinativas, verbos não finitos e sentenças encaixadas, não é possível realizar 'neg3', sendo 'neg2' realizado nas mesmas sentenças com sucesso. As restrições a 'neg3' ainda aumentam se considerarmos ocorrências em tipos diferentes de orações subordinadas. No quadro 4, observamos que, se, por um lado, 'neg2' ocorre sem restrições em todos os contextos apresentados, 'neg3' não pode ocorrer em nenhum dos mesmos contextos apresentados. 
Quadro 4.4 - Distribuição dos marcadores negativos no PB por tipos de orações subordinadas

\begin{tabular}{|c|c|c|c|}
\hline $\begin{array}{r}\text { Tipo de } \\
\text { ubordinada }\end{array}$ & NEG-V & NEG-V-NEG & V-NEG \\
\hline Completiva & $\begin{array}{l}\text { A Maria acha que o } \\
\text { edro não/ num comprou } \\
\text { o carro }\end{array}$ & $\begin{array}{l}\text { A Maria acha que o } \\
\text { Pedro não/ num } \\
\text { comprou o carro não }\end{array}$ & $\begin{array}{c}\text { *A Maria acha que o } \\
\text { Pedro comprou o carro } \\
\text { não. }\end{array}$ \\
\hline Subjetiva & $\begin{array}{l}\text { É melhor não/ num } \\
\text { ficar acordado até } \\
\text { tarde. }\end{array}$ & $\begin{array}{l}\text { É melhor não/ num } \\
\text { ficar acordado até } \\
\text { tarde não. }\end{array}$ & $\begin{array}{l}\text { *É }^{\mathrm{E}} \text { melhor ficar } \\
\text { acordado até tarde não. }\end{array}$ \\
\hline Condicional & $\begin{array}{l}\text { Se você não/ num for } \\
\text { viajar mesmo, passa lá } \\
\text { em casa no fim de } \\
\text { semana. }\end{array}$ & $\begin{array}{l}\text { Se você não/ num for } \\
\text { viajar mesmo não, } \\
\text { passa lá em casa no } \\
\text { fim de semana. }\end{array}$ & $\begin{array}{l}\text { *Se você for viajar } \\
\text { mesmo não, passa lá em } \\
\text { casa no fim de semana. }\end{array}$ \\
\hline $\begin{array}{l}\text { Relativa } \\
\text { explicativa }\end{array}$ & $\begin{array}{l}\text { Tem político que não/ } \\
\text { num rouba }\end{array}$ & $\begin{array}{l}\text { Tem político que não/ } \\
\text { num rouba não. }\end{array}$ & $\begin{array}{l}\text { *Tem político que } \\
\text { rouba não. }\end{array}$ \\
\hline Consecutivas & $\begin{array}{l}\text { O Otávio tava tão } \\
\text { bêbado que não/ num } \\
\text { viu o poste. Bateu em } \\
\text { cheio! }\end{array}$ & $\begin{array}{l}\text { O Otávio tava tão } \\
\text { bêbado que não/ num } \\
\text { viu o poste não. Bateu } \\
\text { em cheio! }\end{array}$ & $\begin{array}{l}\text { *O Otávio tava tão } \\
\text { bêbedo que viu o poste } \\
\text { não. Bateu em cheio! }\end{array}$ \\
\hline
\end{tabular}

Assim, as autoras propõem que existem dois diferentes marcadores negativos finais no $\mathrm{PB}, \mathrm{Neg} 2$ e $\mathrm{Neg} 3^{58}$.

Assumindo a distinção entre os três tipos de negação, referimos ainda o estudo de Sousa (2015), em que é contestada a distinção proposta por Biberauer; Cyrino (2009), em termos das noções de ênfase, pressuposição ou contexto de ativação. Partindo da interpretação do evento discursivo, Souza (2009) propõe que os três tipos de negação do PB (neg1, neg2 e neg3) sejam analisados de acordo com a interpretação dos eventos, que podem ser de duas naturezas: pressuposicionais ou metalinguísticos. A autora afirma que, em termos de interpretação, Neg2 pode ser usado para negar informação nova, enquanto Neg3 não pode. Além disso, neg2 nega apenas proposições, o que a qualifica como uma negação semântica. Por outro lado, neg3 é utilizada como

${ }^{58}$ Neste ponto da análise, a discussão sobre a posição sintática de Neg2 e Neg3 foge ao escopo deste trabalho. Por essa razão, indicamos apenas a presença da negação pré-verbal. 
uma negação metalinguística. Já neg1 é considerada como uma negação semântica sobre os eventos, mas mantém a possibilidade de expressão como uma negação metalinguística.

No presente estudo, não aprofundaremos o debate entre as análises citadas, particularmente porque nossa proposta de análise de imperativas negativas do PB prevê que as características formais e semânticas do imperativo excluem a estratégia Neg3, conforme descrita nesta seção. Assumindo-se que Neg3 não pode negar informação nova, entende-se que terá como requisito que a informação seja dada, o que é incompatível com a leitura do enunciado imperativo, que, por suas características semânticas, não admite interpretação como informação dada. Nesse sentido, nossa hipótese é a de que a negação pós-verbal isolada em sentenças imperativas é uma variante de Neg2 (ou seja, uma configuração do tipo Neg-V-Neg, com apagamento do item Neg na posição mais alta).

Com base nas contribuições das teorias apresentadas até o momento, passamos a examinar a estrutura das sentenças imperativas negativas.

\subsubsection{A negação em estruturas imperativas no $P B$}

O objetivo de análise deste capítulo consiste na diferenciação da configuração do modo imperativo entre o $\mathrm{PB}$ e o $\mathrm{PE}$, no que diz respeito à forma de expressão sintática e semântica da negação de sentenças imperativas. Assim, no PE, observamos uma sintaxe imperativa que restringe a ocorrência de marcadores negativos associada às formas do imperativo verdadeiro. A possibilidade de negar sentenças imperativas no PE ocorre mediante a forma supletiva, com morfologia verbal diferenciada da forma verdadeira de imperativo.

Já no PB, a sintaxe do modo imperativo apresenta particularidades na presença de marcadores negativos. Conforme observado no Capítulo 1, seguindo os resultados de Cardoso (2004; 2009), Scherre et al. (2007) observam que marcadores negativos préverbais tendem a favorecer a forma verbal do imperativo com a morfologia supletiva advinda do modo subjuntivo e a negação pós-verbal e a dupla negação tendem a favorecer o imperativo com morfologia supletiva advinda do modo indicativo. Dados reais que ilustram cada caso estão citados a seguir. 
(31) a. Ei, não tira essas goiabas!

b. Não pule, é perigoso!

c. Faz isso não, homem de Deus!

d. Faça não, deixe disso!

e. Não faz isso comigo não!

f. Não falte não!
$(\mathrm{NEG}+\mathrm{V})$

$(\mathrm{NEG}+\mathrm{V})$

$(\mathrm{V}+\mathrm{NEG})$

$(\mathrm{V}+\mathrm{NEG})$

$(\mathrm{NEG}+\mathrm{V}+\mathrm{NEG})$

$(\mathrm{NEG}+\mathrm{V}+\mathrm{NEG})$

(SCHERRE ET AL.,2007:213)

Assumimos que, nas estruturas imperativas, as formas variáveis associadas ao indicativo e ao subjuntivo, embora caracterizem uma situação de favorecimento da forma subjuntiva, não oferecem restrição sintática a marcadores negativos, independentemente da estratégia de negação. As preferências pelas formas do indicativo ou do subjuntivo estariam associadas a fatores regionais. Em particular, os dialetos falados no nordeste manifestam preferência pelas formas do subjuntivo, o que pode ser relacionado à preferência pela forma do subjuntivo em completivas, atestada em estudos sociolinguísticos (cf. Oliveira 2008). Diante da perda da gramática do imperativo verdadeiro, pelos fatores referidos anteriormente, a ausência de restrição à negação das formas supletivas disponíveis é o resultado esperado.

Conforme proposto em Ferreira Junior (2011) e Salles e Ferreira Junior (2013), a possibilidade de realizar a negação com ambas as formas verbais (indicativo e subjuntivo) está associada à estrutura com o traço optativo em C.

Nas sentenças imperativas negativas com marcadores pré-verbais, Neg se posiciona como uma categoria abaixo de Mod e TP. Nessa configuração, o verbo imperativo (supletivo) se move do vP para o núcleo de Neg, que atua como uma sonda, por seu caráter clítico, e depois para o núcleo de TP. O complexo formado $(\mathrm{Neg}+\mathrm{V})$ move-se para o núcleo de Mod na sintaxe, que, por hipótese, manifesta o traço EPP. Na presença do sujeito pré-verbal, verifica-se o movimento do DP a partir de vP para specTP, a fim de verificar traços phi e de Caso. Nessa configuração, o DP sujeito valora o traço interpretável de $2^{\mathrm{a}}$ pessoa (destinatário) em specMod, conforme a estrutura a seguir. 
(32)

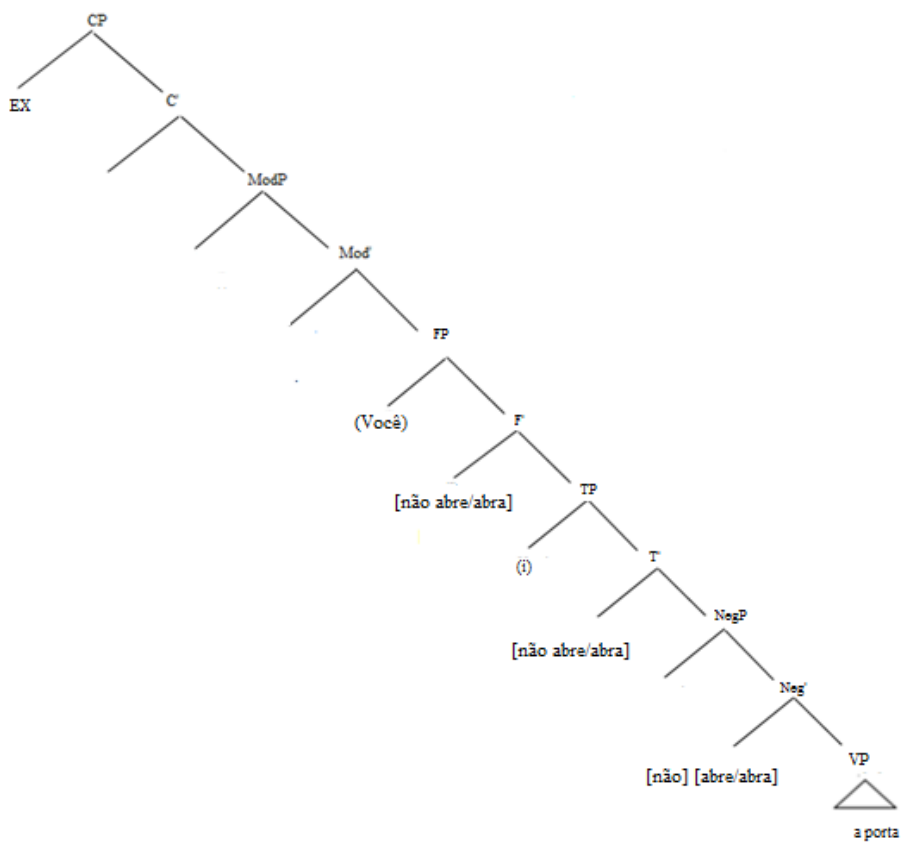

Em consonância com as análises apresentadas na seção anterior, assumimos que existe diferença entre a estratégia da dupla negação (Neg2) e a estratégia da negação em ocorrência isolada pós-verbal (Neg3). Neg1 tem caráter clítico, átono e sua projeção deve c-comandar o complexo nucleado pelo verbo; Neg2 é realizada como uma negação interna na estrutura da oração, seguindo a proposta de Sousa (2015). Neg3 tem realização adverbial.

No entanto, nossa hipótese de trabalho é que a estratégia Neg3 não está disponível para as estruturas imperativas. Em particular, entendemos que as propriedades semântico-discursivas da sentença imperativa bloqueiam o uso da estratégia Neg3, conforme descrita na seção anterior (cf. BIBERAUER; CYRINO 2009; SOUZA 2009) para sentenças declarativas. Em se tratando de um comando diretivo, não é possível atribuir a esse enunciado uma leitura metalinguística, que se caracteriza pela impossibilidade de negar informação nova, já que seu conteúdo é essencialmente informação nova. Nesse sentido, propomos que as sentenças imperativas com Neg pósverbal isolado manifestam as propriedades comparáveis à estratégia da dupla negação, distinguindo-se essencialmente pelo apagamento da primeira ocorrência de Neg. 
As estruturas imperativas com negação pós-verbal isolada permitem concluir que o PB apresenta um padrão semelhante ao francês, no que diz respeito ao ciclo da negação. Nesse sentido, ainda que restrita ao contexto imperativo, é possível afirmar que o PB tenha pelo menos uma fase em que o marcador negativo pós-verbal é caracterizado como item de reforço (cf. Furtado da Cunha (1996); Sousa (2007;2012); Biberauer \& Cyrino 2009).

A essa exigência, acrescentamos a hipótese de que o contexto discursivo da negação no imperativo seja primordialmente favorável ao uso da negação pós-verbal denotadora de ênfase. $\mathrm{O}$ fato de a negação pós-verbal ser favorecida na frase imperativa (em oposição aos demais tipos frasais) sugere que esse marcador adverbial é licenciado pelo traço optativo em C, em uma relação Agree, o que se confirma pelas propriedades quantificacionais dos traços formais em ambas as categorias, respectivamente $[+\mathrm{Neg}] \mathrm{e}$ [+Optativo/EX/1 ${ }^{\mathrm{a}}$ pessoa]. Essa operação seria, por hipótese, condição necessária para a gramaticalização da negação pós-verbal como uma fase do Ciclo de Jespersen no PB.

Nesse contexto, é possível afirmar que não somente o PB desenvolveu um parâmetro peculiar em relação ao $\mathrm{PE}$, mas também a sintaxe do imperativo é o produto de diversas mudanças paramétricas, trazendo características inovadoras. Esse conjunto de mudanças ainda se estende a dois outros fatores: o licenciamento do sujeito préverbal e de marcadores negativos na estrutura de dupla negação e de negação pós-verbal isolada mediante as propriedades codificadoras da modalidade optativa.

Nas sentenças imperativas negativas com marcadores pré-verbais, Neg se posiciona como uma categoria abaixo de Mod e TP. Nessa configuração, o verbo imperativo (supletivo) se move do vP para o núcleo de Neg, que atua como uma sonda, por seu caráter clítico, e depois para o núcleo de TP. O complexo formado $(\mathrm{Neg}+\mathrm{V})$ manifestando o traço supletivo não interpretável entra em uma relação Agree com o núcleo de Mod na sintaxe fechada, verificando o traço diretivo. Na presença do sujeito pré-verbal, verifica-se o movimento do DP a partir de vP para specTP, a fim de verificar traços phi e de Caso. Nessa configuração, o DP sujeito valora o traço interpretável de $2^{\mathrm{a}}$ pessoa (destinatário) em specMod.

\subsection{Considerações finais do capítulo}

Este capítulo teve como objetivo identificar a relação de aspectos sintáticos da negação no português brasileiros com a configuração de sentenças imperativas. Foi 
possível identificar que as inovações apresentadas nas sentenças imperativas negativas do PB permitem um claro contraste com o português europeu (PE), classificado como língua de imperativo verdadeiro de Classe I, conforme proposto por Rivero (1994) e Rivero; Terzi (1995).

Através dessa análise, vimos que Rivero (1994) aponta restrições sintáticas ao movimento da negação para checagem de traços na categoria $\mathrm{C}$ em sentenças com a forma verdadeira, haja vista o núcleo da categoria Neg se tornar uma barreira para a hospedagem do verbo na categoria $\mathrm{C}$, responsável pela força ilocucionária. Em seguida, apresentamos a análise de Han (1999), que argumenta que o caráter clítico da negação permitiria o movimento desse item para a categoria $\mathrm{C}$, sem violar, portanto, a minimalidade postulada no estudo de Rivero (1994). Propõe, então, que a restrição à negação se deve à impossibilidade de que a negação tenha escopo sobre a força ilocucionária imperativa da sentença, o que geraria um problema de restrição semântica.

Verificando-se que o PB, diferentemente do PE, não apresenta restrições categóricas em relação à negação de sentenças imperativas, apresentamos a análise de Zannutini (1995) sobre os dois padrões de negação (um gramatical, de caráter clítico, e um de caráter adverbial), que parece ser adequada para explicar as estratégias de negação no PB. O desenvolvimento das três estratégias de negação no PB é, então, associado em Ramos (2006) ao processo já descrito por Zannutini (1995) e também apresentado por Vitral (2006), em que a ocorrência das estratégias de negação estaria submetida às etapas do Ciclo de Jespersen. Essa variação compreende a mudança da negação pré-verbal para um padrão pós-verbal, passando por estágios com formas em que ocorre também a dupla negação. Ramos (2006) apresenta a variação entre as formas pré-verbais 'não/num' como evidência de que esse ciclo seja observado no PB, assim como já ocorreu em outras línguas.

Finalmente, demonstramos a derivação das imperativas negativas com negação pré-verbal. Em relação a estruturas imperativas negativas, nossa proposta é a de que as estruturas de dupla negação e de negação isolada pós-verbal se identificam na sintaxe (sendo, portanto, equivalentes), distinguindo-se essencialmente pelo apagamento do item mais alto, em PF. Dessa forma, concluímos que a estratégia Neg3 não está disponível em sentenças imperativas. 


\section{CAPÍTULO 5}

\section{CONSIDERAÇÕES FINAIS}

O objetivo principal deste trabalho foi investigar propriedades sintáticas e semânticas das sentenças imperativas no português brasileiro (PB), haja vista que, em comparação com o português europeu (PE), essa língua apresenta uma configuração inovadora. A hipótese apresentada é a de que o surgimento dessa configuração inovadora está associado a um conjunto de propriedades que distinguem o PB em relação ao PE - a reanálise do sistema pronominal; a neutralização das formas do indicativo e do imperativo em orações completivas; o surgimento de diferentes estratégias na sintaxe da negação, as inovações na sintaxe do sujeito e as restrições à ordem VS), resultando na desarticulação da gramática do imperativo verdadeiro no PB. Dessa maneira, diferentemente do PE, o PB apresenta apenas um sistema imperativo de base exclusivamente supletiva.

Com o objetivo de compreender a estrutura das sentenças imperativas do PB, nos dedicamos a investigar a hipótese de que o imperativo no PB é caracterizado por um $\mathrm{CP}$ optativo, que hospeda um operador semântico (EX), que representa uma escala que excede um limite definido no contexto, nos termos de Grosz (2011), marcando a expressão do desejo do emissor na elocução imperativa. Por hipótese, esse operador permite ao emissor direcionar ao destinatário a mensagem imperativa com diferentes matizes de polidez, ao imprimir uma gradação (escala) ao seu desejo. Além disso, na estrutura imperativa do $\mathrm{PB}$, o núcleo $\mathrm{C}$ com o traço optativo seleciona uma projeção que é marcada com um traço diretivo/ jussivo, cujo especificador hospeda um traço interpretável de segunda pessoa do discurso, no espírito da análise de Zanuttini (2008) e de Isac (2015). Essa projeção é referida como ModP. Assim, defendemos que a expectativa do emissor do ato de elocução imperativo se manifesta na relação com a sintaxe do sujeito - em que a realização nula alterna com a realização lexical, em posição pré-verbal (não marcada), em contraste com a posição pós-verbal (marcada). Essa configuração compreende ainda a representação de duas instâncias de causa na expressão do ato de fala imperativo, conforme propõe Isac (2015). O primeiro evento de causa está diretamente associado à presença do operador optativo em $\mathrm{C}$, e representa a expectativa que o emissor tem ao realizar a proposição inicial do ato de elocução. Já o 
segundo evento de causa está associado ao traço de segunda pessoa hospedado na categoria Mod.

Além disso, pelo fato de que, na configuração supletiva, o verbo não realizam movimento para $\mathrm{C}$, na sintaxe aberta, para checagem do traço optativo, permanecendo, assim, em Mod, não são identificadas restrições a marcadores negativos, diferentemente das sentenças imperativas do PE, o que torna o português brasileiro uma língua com uma configuração imperativa inovadora. Nessa configuração, é possível ainda a ocorrência de sujeitos abertos em posição pré-verbal, no especificador de ModP.

O percurso deste trabalho consistiu em apresentar, no capítulo 1, o quadro teórico de análise desta pesquisa. Seguiu-se a caracterização do modo imperativo sob a perspectiva translinguística, observando, segundo Rivero (1994) e Rivero \& Terzi (1995), as características sintáticas das sentenças imperativas de línguas de Classe I e Classe II, que se distinguem, respectivamente, por admitirem ou não a negação da forma imperativa verdadeira. Após essa análise, passamos à análise do contraste entre as características das sentenças imperativas no PB e no PE. Em relação ao PB, destacamos a existência do uso variável de formas imperativas associadas ao indicativo e do subjuntivo, tomando como referência estudos de Scherre (2003, 2007, 2008); Cardoso (2004; 2009), Scherre et al. (2007), desenvolvidos na abordagem variacionista laboviana. Em particular, observamos que a distribuição das formas variantes do modo imperativo tem uma determinação nas regiões do Brasil. Essa análise permitiu confirmar que as formas associadas ao indicativo e ao subjuntivo ocorrem em variação sem implicar distinção de configuração sintática, uma vez que as formas verbais no contexto de uso do imperativo não apresentam restrições ao uso de marcadores negativos. Verificamos também que o posicionamento de sujeitos abertos manifesta-se em diferentes estratégias (pré-verbal ou pós-verbal).

Assumimos, seguindo os autores, que o desenvolvimento do paradigma supletivo associado ao indicativo (em variação com as formas associadas ao subjuntivo) relaciona-se à reanálise do sistema pronominal e ao sincretismo morfológico decorrente, que proporciona as inovações apresentadas no que diz respeito ao uso das formas verbais variantes e de sujeitos lexicalmente realizados em ordem SV.

No capítulo 2, demonstramos a necessidade de se projetar uma categoria específica para codificar a modalidade diretiva/ jussiva - designada como Modality Phrase (ModP) na estrutura sintática das sentenças imperativas. Seguindo Isac (2015), formulada no espírito da proposta original de Zanuttini (2008), postulamos que as 
sentenças imperativas possuem uma categoria responsável pelos traços de modalidade em uma posição relativamente alta na estrutura oracional. Essa configuração no PB permite (i) captar o licenciamento do traço diretivo, relacionado à segunda pessoa do discurso na elocução imperativa, tal como o traço jussivo proposto por Zanuttini (2008) e (ii) captar a existência de diversos matizes de polidez associadas às sentenças imperativas do PB. Assim, a composição da estrutura imperativa é formalmente estabelecida pela projeção de duas categorias: um $\mathrm{C}$ marcado por um operador optativo e que licencia um traço intrínseco de primeira pessoa e uma categoria Mod, ccomandada e selecionada pelo $\mathrm{C}$ optativo, que hospeda os verbos imperativos e licencia o traço de segunda pessoa, permitindo a ocorrência de sujeitos nulos ou realizados lexicalmente em posição pré-verbal.

No capítulo 3, iniciamos a análise, apresentando a proposta da configuração optativa, seguindo Grosz (2011). Grosz postula um operador EX que indica, na elocução optativa, a força expressiva do falante em um escala contextual em relação a um enunciado. Adotamos essa proposta, postulando que as sentenças imperativas do PB demonstram um comportamento de sentenças optativas. Em seguida, apresentamos a análise de Zanuttini (2008) e Isac (2015), em que é postulada a presença do traço de segunda pessoa nas estruturas imperativas, em uma categoria marcada para um traço de modalidade diretiva/jussiva. Em nossa proposta, o traço jussivo ocorre na projeção jussiva, que hospeda a segunda pessoa do discurso - o destinatário do ato de elocução imperativo - no seu especificador. Adotar essa configuração nos permite explicar a associação das formas supletivas a sujeitos abertos em ordem SV no PB.

Ainda neste capítulo investigamos as estratégias de posicionamento dos sujeitos abertos no PB. Vimos que os sujeitos podem ocorrer em posição pré-verbal e pósverbal. Apresentamos, ainda, uma proposta para solucionar a ambiguidade das estruturas declarativas e imperativas na ordem SV com a forma verbal advinda do indicativo (Você abre a porta! ;Você abre a porta.). Demonstramos que as duas sentenças possuem configurações sintáticas distintas e que, por esse motivo, a ambiguidade é apenas aparente.

No capítulo 4 tivemos como objetivo apresentar a análise de aspectos sintáticos de sentenças imperativas negativas no PB. Inicialmente, recuperamos a discussão apresentada no capítulo 1 com o objetivo de identificar as restrições aos marcadores negativos apontadas na análise de Rivero (1994) e Rivero \& Terzi (1995) para as sentenças imperativas com a forma verdadeira, em que é postulado um efeito de 
minimalidade da projeção NegP ao movimento do verbo para C. Observamos que, no $\mathrm{PE}$, as formas verdadeiras oferecem restrições à ocorrência de marcadores negativos, e recorre a formas supletivas para realizar a negação de sentenças imperativas. Em seguida, apresentamos a proposta de Han (1999), que alega que o movimento do verbo para $\mathrm{C}^{\circ}$ não é bloqueado pela sintaxe, mas pela semântica, como consequência do efeito do escopo da negação sobre a força ilocucionária da sentença. Nessa discussão, foi questionado o argumento de Han quanto à restrição de escopo, mantendo-se a proposta baseada na sintaxe. Diante do fato de que o PB, diferentemente do PE, não apresenta restrição à negação de sentenças imperativas, passamos a examinar a análise de Zannutini (1995) sobre para o posicionamento dos marcadores de negação na estrutura oracional. Em seguida, demonstramos que o PB permite a ocorrência de três diferentes estratégias de negação: com a ocorrência do marcador negativo na posição pré-verbal (Neg-V), pós-verbal (V-Neg) e simultaneamente em ambas as posições (Neg-V-Neg), assumindo a proposta de Ramos (2006) de que existe uma relação entre enfraquecimento do marcador negativo pré-verbal e manifestação das diferentes estratégias. Nessa direção, assumimos, conforme Vitral (2006), que tanto o enfraquecimento do marcador negativo pré-verbal como a realização de dupla negação apontam para a realização do Ciclo de Jespersen para a negação do PB, permitindo correlacionar a etapas do ciclo em questão aos processos de licenciamento formal dos marcadores negativos no PB. Assumindo o estudo de Biberauer; Cyrino (2009) em relação às estratégias de negação do $\mathrm{PB}$, que distingue três tipos de marcadores de negação, respectivamente Neg1 (Neg-V), Neg 2 (Neg-V-Neg) e Neg 3 (V-Neg), concluímos que as sentenças imperativas não manifestam Neg 3, que corresponde a enunciados que não codificam informação nova. Nesse sentido, as ocorrências de enunciados imperativos na ordem V-Neg são instâncias de Neg2, com o apagamento em PF da primeira ocorrência de Neg.

Entre as contribuições, entendemos que este trabalho avança em relação ao entendimento da estrutruras imperativas, cabendo avaliar de que maneira essa proposta se aplica a outras línguas. Muitas questões permanecem em aberto, como a relação entre a realização lexical do sujeito e a ocorrência da ordem SV e VS, os detalhes da projeção sintática das estratégias de negação, a sintaxe dos clíticos pronominais, além da formalização das propriedades semânticas informalmente assumidas, o que reservamos para a pesquisa futura, na expectativa de avançar o entendimento das propriedades da gramática universal. 


\section{REFERÊNCIAS BIBLIOGRÁFICAS}

ALKMIN, M. G. R. (2002) Estudo da variação do modo imperativo em obras de Jorge Amado. Ms., Universidade de Brasília.

AZEREDO, J. C. (2008) Gramática Houaiss da Língua Portuguesa. Publifolha, São Paulo.

BECHARA, E. (2003) Moderna gramática portuguesa. RJ: Lucerna.

BELLETTI, A. Aspects of the low IP area. In: RIZZI, Luigi. The structure of CP and IP: The cartography of syntactic structures. Oxford, New York: Oxford University Press, 2004. v. 2, p. 16 - 51.

BIBERAUER, T., (2009). Jespersen of course? The case of contemporary Afrikaans negation. In: Gelderen, E. (Ed.), Cyclical Changes, vol. 146. John Benjamin, Amsterdam, pp. 91.

BIBERAUER, T; CYRINO, S (2009). Apearances are deceptive: Jespersen's Cycle from the perspective of the Romania Nova and Romance-based Creoles, paper presented at Going Romance 23, University of Nice

CARDOSO, D. B. B. (2009). Variação e mudança do imperativo no português brasileiro: gênero e identidade. Tese de doutorado.

- (2006) O imperativo gramatical no português do Brasil. Revista de Estudos da Linguagem, v. 14, $\mathrm{n}^{\mathrm{o}}$ 2. Universidade Federal de Minas Gerais. PP 317-340.

CARVALHO, J. B. de. (1989). Phonological conditions on Portuguese clitic placement: on syntactic evidence for stress and rhythmical patterns. Linguistics

27 , p. 405-436.

CASTILHO, A. (2010) Nova gramática do português brasileiro. SP: Contexto.

CAVALCANTE, R. (2007). A negação pós-verbal no português brasileiro: análise descritiva e teórica de dialetos rurais de afro-descendentes. Salvador: UFBA. Dissertação de Mestrado.

. (2010). Interação entre imperativo e negação. Revista de Estudos da Linguagem, dezembro de 2010. v. 8, n. 2, p. 9-36.

. (2012) Negação anafórica no Português Brasileiro: Negação sentencial, negação enfática e negação de constituinte. São Paulo. Tese (Doutorado em Linguística) - Universidade de São Paulo, 
CHOMSKY, N. (1981). Lectures on Government and Binding. Dordrecht: Foris.

Praeger. (1986) Knowledge of Language: its origin, nature and use. New York: (1995) The Minimalist Program, Current studies in linguistics 28, MIT Press, Cambridge, MA. . (1998) Minimalist inquiries: the framework. MIT OPL 15. Dept. of Linguistics, MIT. (1999) O Programa Minimalista. Tradução de Eduardo Raposo. Lisboa: Caminho. Título original: The Minimalist Program. (2002). Derivation by Phase. Ken Hale: A Life in Language. Kenstovicz, Michael (ed). Cambridge, Mass: MIT Press. pp. 1-54.

CINQUE, G; RIZZI, L. (2008) The cartography of syntactic structures. CISCL Working Papers, Siena, v. 2, p. 42 - 58.

CUNHA, C. \& CINTRA, L. (2001) Nova Gramática do Português Contemporâneo“, $3^{a}$ Edição revisada, $5^{a}$ Reimpressão, Ed. Nova Frunteira.

Dahl, Ö., (1979) Typology of sentence negation. Linguistics 17 (1--2), 79--106.

DUARTE, M. E. (2000) "The loss of the 'avoid pronoun' principle in Brazilian Portuguese". In: Kato, Mary \& Esmeralda Negrão (eds.) Brazilian Portuguese and the Null Subject Parameter. Frankfurt, Vervuert.

DUARTE, I. (2004). "Padrões de colocação dos pronomes clíticos". In Mateus, M. H. M., Brito, A. M., Duarte, I. Faria, I. H. et al. Gramática da Língua Portuguesa, $6^{\text {a }}$ edição, Lisboa, Caminho, 847-867.

FARACO, C. A. (1986)Considerações sobre a sentença imperativa no português do Brasil. D.E.L.T.A., Vol. 2, no 1, p. 1-15.

Fragmenta 13: 51-82. (1996) O tratamento você em português: uma abordagem histórica

FERREIRA JUNIOR, M. N. (2011) A sintaxe da negação em configuração imperativa no português brasileiro. Dissertação de Mestrado. Universidade de Brasília.

SALLES, H.M.M.L \& FERREIRA JUNIOR, M.N. (2013) Aspectos sintáticos dos marcadores negativos no português brasileiro - restrições de ocorrência em sentenças com marcadores pós-verbais. In IV Simpósio Mundial de Estudos de Língua Portuguesa. Anais. Goiânia. p. 1832-1838

- (2015) Propriedades morfossintáticas e semânticas de sentenças imperativas no português brasileiro. In. VII Encuentro de Gramática Generativa (EGG7) Museo del Libro y de la Lengua Buenos Aires - BA. 29,30 e 31 de julho 
(2016) O imperativo no PB: propriedades tipológicas e estruturais. In:

Temas em Teoria Gerativa: homenagem a Lúcia Lobato. Brasília. Ed Blanche $1^{\mathrm{a}}$ ed.

von FINTEL, K. (2006) Modality and language. In: BORCHERT, D. enciclopedia of Philosophy. Detroit: MacMillan Reference.

FIGUEIREDO SILVA, M. C. (1996). A Posição do Sujeito no Português Brasileiro: Frases Finitas e Infinitivas. Campinas: Editora da UNICAMP.

FURTADO DA CUNHA, M. A. (2001) O modelo das motivações competidoras no domínio funcional da negação. D.E.L.T.A. 17.1: 1-30

GROSZ, P. (2011) On the grammar of optative constructions. . Ph. D. Thesis. MIT. Massachusetts Institute of Technology, Dept. of Linguistics and Philosophy, 2011 September.

GAGLIETI, M., BARBOSA, M.H.S. A brasilidade no entre-lugar: leituras de Dyonélio Machado e Sérgio Buarque de Holanda. Letras de Hoje. Porto Alegre, v. 41, n. 3, p. 29-36, setembro, 2006.

HAN, Chung-Hye. (1999). Cross-linguistic variation in the compatibility of negation and imperatives. Proceedings of the 17th West Coast Conference on Formal Linguistics. CSLI, Stanford, 265-279. (2001). Force, negation and imperatives. The Linguistic Review 18, p. 289-325.

HOPPER, P J., and C TRAUGOTT, E. C.. Grammaticalization. Cambridge, England: Cambridge University Press. 256 pages (1993).

HORNSTEIN, Norbert; NUNES, Jairo; GROHMANN, Kleanthes K. (2005).

Understanding Minimalism. Cambrigde: Cambrigde University Press.

ISAC, D. (2015) The Morphosyntax of Imperatives. Oxford Studied in Theoretical Linguistics. Oxford United Press, UK. First edition

JESPERSEN, O. (1971) The Philosophie de la Grammaire. Tradução francesa de The Philosophy of Grammar. Paris: Editions de Minuit.

JESUS, É. T. (2006). O Nordeste na mídia e os estereótipos linguísticos: Estudo do imperativo na novela Senhora do Destino. Brasília. Dissertação de Mestrado, Universidade de Brasília (UnB)

KATO, M.A. (1999). 'Strong Pronouns, Weak Pronominals and the Null Subject Parameter'. Probus. 11: 1. pp. 1-37.

KATZ,.J.J. and POSTAL (1964).An Intergrated Theory of Linguistic Description, The MIT Press: Cambridge, Mass. 
KATO, M. A.; MIOTO, C. (2005) A multi-evidence study of European and Brazilian

Portuguese wh-questions. In: KEPSER, S.; REIS, M. (Orgs.). Linguistic evidence:

empirical, theoretical and computational perspectives. Berlin; New York: Mouton de Gruyter,. p. 307-328.

KENEDY, E. (2013). Curso básico de linguística gerativa. SP: Contexto,

KRATZER, A. (1991) Modality. In: von STECHOW, A; WUNDERLICH, D. Semantics: an international handbook of contemporary research. Berlin: Mouton de Gruyter.

LAKA, I. (1990). Negation in syntax: on the nature of functional categories and Projetions. MIT, PhD Thesis.

Force, negation and imperatives. (2001). The Linguistic Review 18, p. 289325.

LOPES, C.R.S. (1999). A inserção de a gente no quadro pronominal do português: Percurso histórico. Rio de Janeiro: Tese de Doutorado, Letras/UFRJ.

MATOS, G. "Aspectos sintácticos da negação". In Mateus, M. H. M., Brito, A. M., Duarte, I. Faria, I. H. et al. (2004). Gramática da Língua Portuguesa, 6ª edição, Lisboa, Caminho, 767-793

MATTOS E SILVA, R. V. (1993) O português arcaico - morfologia e sintaxe. São Paulo: Contexto.

MATEUS, M. H. M. et alii. (2003) Gramática da língua portuguesa. $5^{a}$ edição revista e aumentada. Lisboa: Caminho.

MATOS E SILVA, R. V. (1993). Português brasileiro: raízes e trajetórias (Para a construção de uma história). Discursos, Lisboa, n.3, p. 75-92, 1993.

MARTINS, E. E. (1997). Sentential negation in spoken Brazilian Portuguese. Washington: Georgetown University. Dissertação de Mestrado.

MIOTO, C. (1991). Negação sentencial no português brasileiro e a teoria da gramática. Campinas: UNICAMP, Tese de Doutorado.

(2005). As interrogativas-Q do Português Brasileiro.Revista da ABRALIN, Belo Horizonte, MG, v. 4, n. 1 e 2, p. 171-196.

NAMIUTI, C. (2008) Aspectos da história gramatical do português. Interpolação, negação e mudança. UNICAMP. Campinas-SP.

NUNES, L.L. (2014) Motivações pragmáticas para o uso de dupla negação: um estudo do fenômeno em português europeu. Dissertação de mestrado. UFGRS. Porto Alegre. 
OLIVEIRA, F. (2003) Modalidade e modo. In. MATEUS, M et al. Gramática da língua portuguesa. ed. Caminho, Lisboa.

OLIVEIRA, M. C. (2007) O uso do modo verbal em estruturas de complementação no português do Brasil. Ms., Universidade de Brasília.

PERINI, M. (2010). Gramática do português brasileiro. SP: Parábola

PILATI, E. (2006). Aspectos sintáticos e semânticos da ordem verbo-sujeito no português. Tese de Doutorado. Brasília: UnB.

POLLOCK, J. (1989). Verb movement, universal grammar, and the structure of IP.

Linguistic Inquiry 20, 365-424.

PORTNER, P. (2002) The semantics of mood. In L. Cheng \& R. Sybesma The second glot international state-of-the-article book: the latest in linguistics. Mouton de Gruyter (2007). Imperatives and modals. Natural Language Semantics, 15(4):

$351-83$.

RABELO, P. C. (2010) Argumentos (EPP) nulos no português do Brasil em contextos oracionais finitos e infinitivos. Universidade de Brasília. Tese de Doutorado.

RAMOS, J. (2006) O processo não > num na fala. Em J. Ramos\& L. Vitral, Gramaticalização: uma abordagem formal, p.119-132. Rio de Janeiro: Tempo Brasileiro/UFMG.

RAPOSO, Eduardo. Apresentação: Da teoria de Princípios e Parâmetros ao Programa Minimalista: algumas ideias-chave. In: CHOMSKY, Noam. O programa Minimalista. Tradução de Eduardo Paiva Raposo. Lisboa: Caminho, 1999. p. 15 - 37.

RIZZI, Luigi. The fine structure of the left periphery. In: HAEGEMAN, Liliane (Ed.).

Elements of grammar: handbook of gererative syntax. Dordrecht, Boston, London:

Kluwer Academic Publishers, 1997, p. 281 - 337.

RIVERO, M. (1994). Negation, imperatives and Wackernagel effects. Rivista di Linguistica 6. 39-66.

\& A. Terzi. (1995). Imperatives, V-movement and logical mood. Journal of Linguistics 31.2:301-332.

RIZZI, L. (1982). Issues in Italian Syntax. Dordrecht: Floris.

ROBERTS, I. (1999) Comparative Syntax, London: Edward Arnold.

ROBERTS, I. (2007) Diachronic Syntax Ian Oxford Textbooks in Linguistics. Oxford: University Press. Hardcover. 508 pp 
ROCHA, R. C. F. (1997) A alternância indicativo/ subjuntivo nas orações subordinadas substantivas em português. Dissertação de Mestrado. Universidade de Brasília.

SAMPAIO, D. A. (2001). Modo imperativo: Sua manifestação/expressão no português contemporâneo. Salvador: Dissertação de Mestrado, Universidade Federal da Bahia SALLES, H. M. M. L. (2007) "Complementação oracional na Diacronia do Português do Brasil" In: CASTILHO, A. et al. (Orgs) Descrição, História e Aquisição do Português Brasileiro. Campinas/SP. Editora Pontes v. 1. 403-418.

SCHERRE, M. M. P. (2003) Norma e uso na expressão do imperativo em revistas em quadrinhos da Turma da Mônica. In: SILVA, Denize Elena Garcia da; LARA, Gláucia Muniz Proença \& MAGAZZO, Maria Adélia (orgs.). Estudos de linguagem- Inter relações e Perspectivas. Campo Grande: UFMS. p. 177- 191.

. (2004). Norma e uso - O imperativo no português brasileiro. In: W.

Dietrich \& V. Noll (orgs.) O português do Brasil - Perspectivas da pesquisa atual. Frankfurt AM Main: Vervuert/Madrid: Iberoamericana. 231-260.

. (2007) Aspectos sincrônicos e diacrônicos do imperativo gramatical no português brasileiro. Alfa, São Paulo, 51 (1): 189-222.

. (2008). O imperativo gramatical no português brasileiro: reflexo de mudança linguística na escrita de revistas em quadrinhos In: Anthony Julius Naro e a Lingüística no Brasil: uma homenagem acadêmica.1 ed. Rio de Janeiro: FAPERJ/7Letras, p. 306-319.

(2012) Padrões sociolinguísticos do português brasileiro: a importância da pesquisa variacionista. Revista do Programa de Pós-Graduação em Estudo de Linguagens Universidade do Estado da Bahia - UNEB

Departamento de Ciências Humanas - DCH I NÚMERO 04 - junho de 2012.

CARDOSO, D. B. B.; LUNGUINHO, M. V.; SALLES, H. M. M. L. A. . (2007) Reflexões sobre o Imperativo em Português. DELTA. Documentação de Estudos em Lingüística Teórica e Aplicada, v. 23, p. 193-241,

SCHWENTER, S. A. (2004) "Fine-Tuning Jespersen's Cycle." Drawing the Boundaries of Meaning: Neo-Gricean Studies in Pragmatics and Semantics in Honor of Laurence R. Horn, ed. by Betty J. Birner and Gregory Ward. Amsterdam:

Benjamins.

(2005) The pragmatics of negation in Brazilian Portuguese. Lingua 115.1427-56, 
SEIXAS, V.; ALCKMIN, T.; CHAVES, E. (2012) Construções negativas na fala de moradores da zona rural do município de Piranga, Estado de Minas Gerais: uma análise variacionista. Acta Scientiarum. Language and Culture Maringá, v. 34, n. 2, p. 269-276, July-Dec.,

SKINNER, B. F. (1953). Ciência e Comportamento humano. São Paulo: Martins Fontes.

SOUSA, L.T. (2007). Formas reduzidas de itens negativos no Português Brasileiro. Dissertação de mestrado. Fale/UFMG.

- (2014) Sintaxe e interpretação de negativas sentenciais no português brasileiro. Tese de doutorado. UNICAMP. Campinas.

. (2015) Three types of negation in Brazilian Portuguese. Lingua 159 (2015) $27-46$.

VAN DER AUWERA, J. The Jespersen Cycles. In.: Gelderen, E. (ed.). Cyclical

Change. John Benjamim: Amisterdam/Philadelphia, 2009, p. 35-72.

VITRAL, L. (2006) A negação: teoria da checagem e mudança lingüística. Em J.

Ramos \& L. Vitral, Gramaticalização: uma abordagem formal, p.119-132. Rio de Janeiro: Tempo Brasileiro/UFMG.

WURFF, Wim van der. (2007) Imperative Clauses in Generative Grammar: an introduction. In: WURFF, Wim van der. (ed.). Imperative Clauses in Generative Grammar: Studies Offered to Frits Beukema. Amsterdam: John Benjamins, 1-94.

ZANUTTINI, R. (1991) Syntactic Properties of Setential Negation: A Comparative Study of Romance Languages. Tese de doutorado, Universidade da Pennsylvania. . (1995). Reflexes of clausal estructures in the syntax of negation: a comparative study of romance languages. Georgetown University. . (1997) Negation and clausal structure: A comparative study of Romance languages. New York: Oxford University Press. 201 pages.

. (2008). Encoding the addressee in the syntax: Evidence from English imperative subjects. Natural Language \& Linguistic Theory 26 (1): 185-218. 
